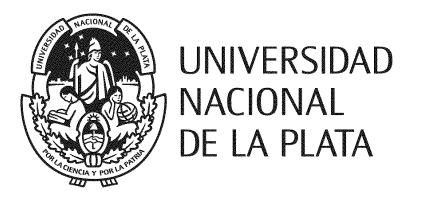

Facultad de Bellas Artes

Secretaría de Posgrado

\title{
EL LUGAR DEL PÚBLICO EN LAS INSTALACIONES INTERACTIVAS Y ROBÓTICAS DEL ARTE ELECTRÓNICO EN BUENOS AIRES
}

\author{
Harold Miranda Poveda \\ Una tesis presentada para obtener el grado de \\ Magister en Estética y Teorías del Arte \\ Director de Tesis: Ing. Emiliano Causa. UNLP \\ Codirectora de Tesis: Lic. Silvia Susana García. UNLP
}

La Plata, Abril de 2017 


\section{Tabla de contenido}

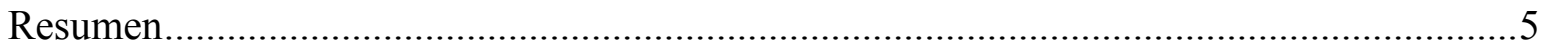

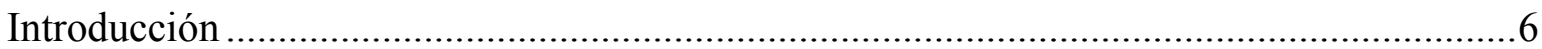

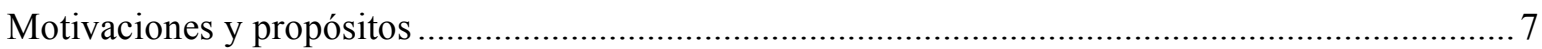

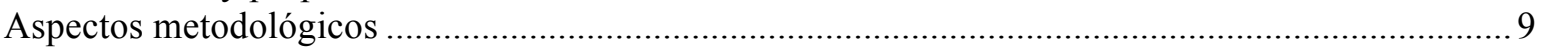

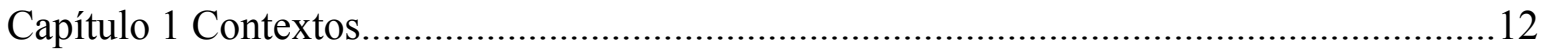

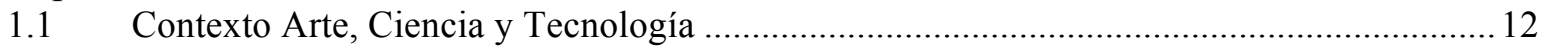

1.2 Contexto estético

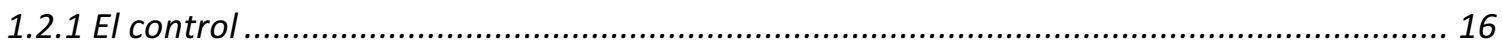

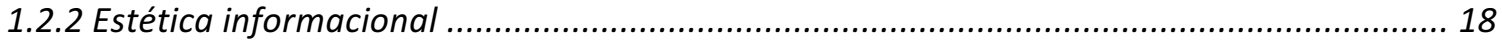

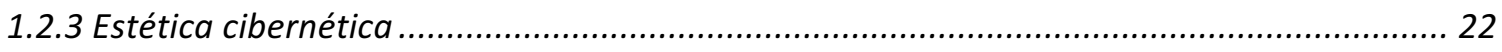

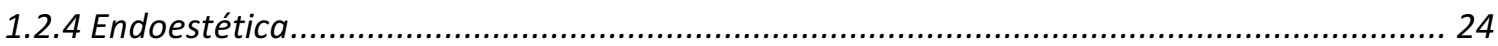

Capitulo 2 Antecedentes de las artes electrónicas en Buenos Aires......................................28

2.1 Instituciones que han favorecido el desarrollo y la expansión de las artes electrónicas................32

2.2 Eventos emblemáticos en torno al arte electrónico en Buenos Aires 2002 - 2012 .......................36

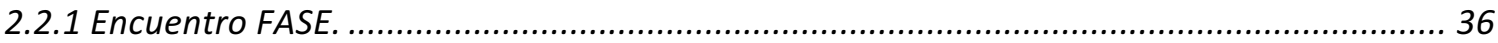

2.2.2 Centro Cultural de España en Buenos Aires. MediaLab proyectos. CCEBA. ....................... 38

2.2.3 Premios MAMBA - Fundación Telefónica - Arte y Nuevas tecnologías.............................. 40

Capítulo 3 Arte electrónico …………………………...................................................4

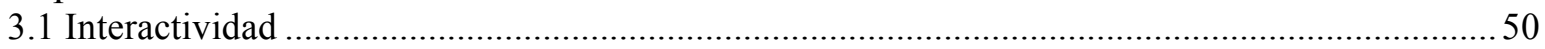

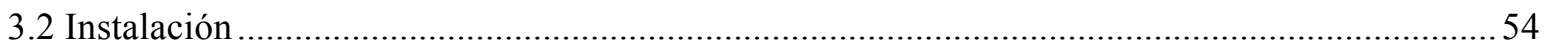

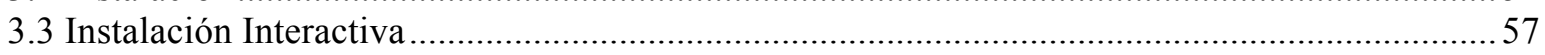

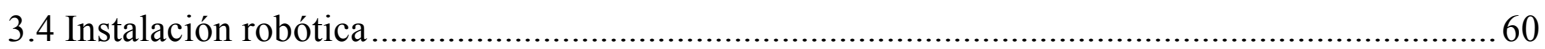

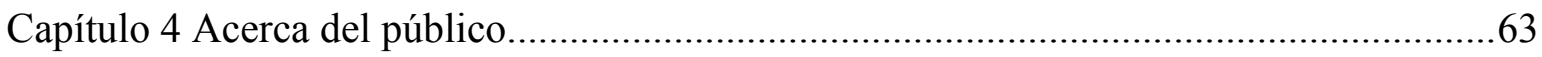

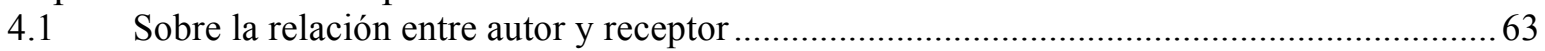

4.2 Sobre la relación entre el público y arte electrónico...............................................................67

4.3 Sobre la intencionalidad del artista y la participación del público. .......................................69

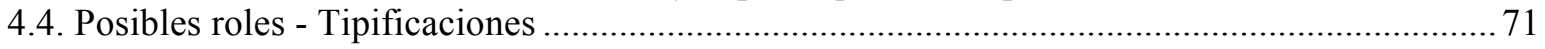

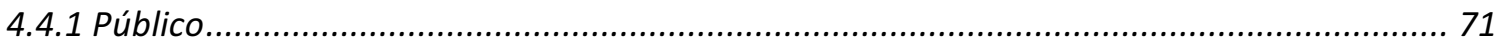

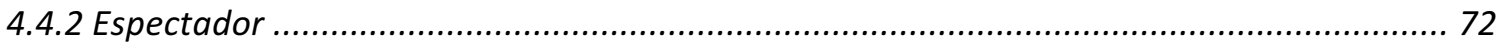

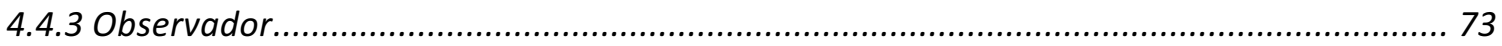

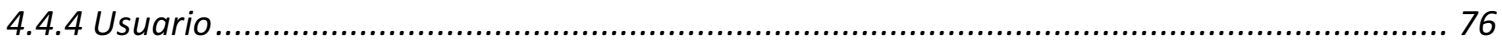

4.4.5 Actor

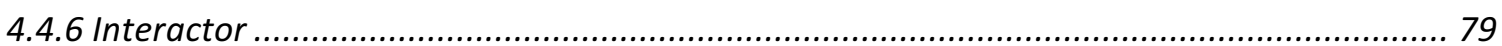

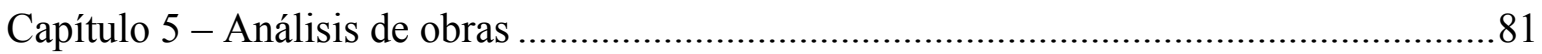

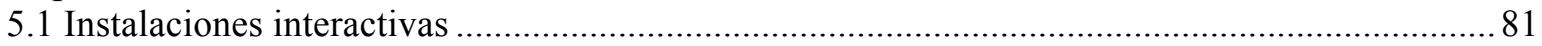

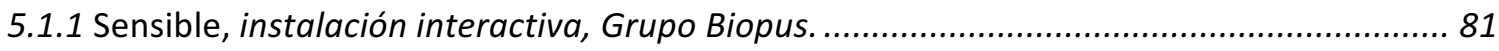

5.1.2 Tango Virus, instalación interactiva, Grupo Biopus. ..................................................... 90

5.1.3 Libros de arena, instalación Interactiva, Mariano Sardón .............................................. 98

5.1.4 Efecto Mariposa, instalación Interactiva, Patricio Gonzalez Vivo .................................. 107

5.1.5 Calor, Humedad y Vapor. Turner en el Siglo XXI, instalación interactiva, Marina Zerbarini.117

5.1.6 Los Aparatos, instalación Interactiva, Federico Joselevich - Julia Vallejo.......................... 123

5.1.7 Generación de Conciencia II - de la serie @Agua_Y_Aceite Video instalación interactiva,

Daniel Alvarez Olmedo, Diez Diego, Guido Villar. ……………………………………...... 129

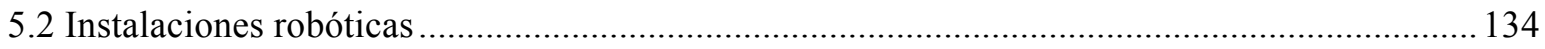




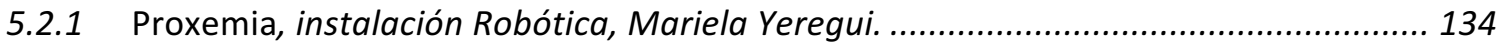

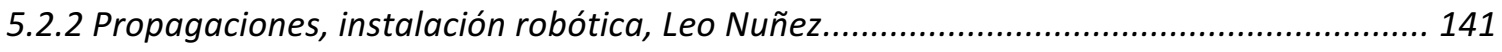

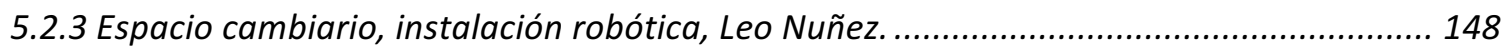

5.2.4 Alexitimia, instalación Robótica, Paula Gaetano. ....................................................... 153

5.2.5 Generación de Conciencia I, Instalación Robótica. Daniel Álvarez Olmedo, Diego Díez, Guido

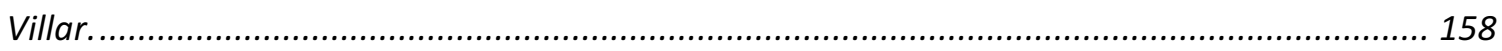

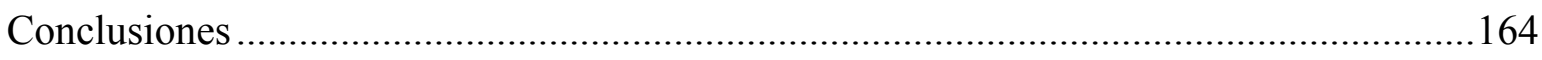

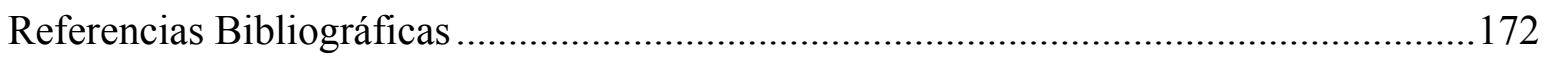

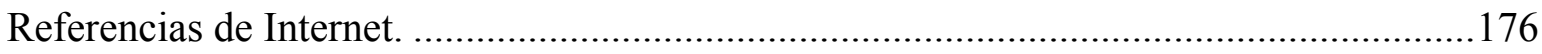

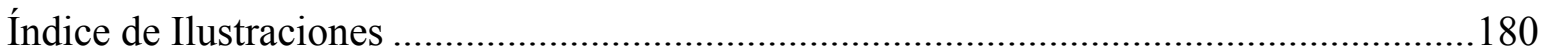

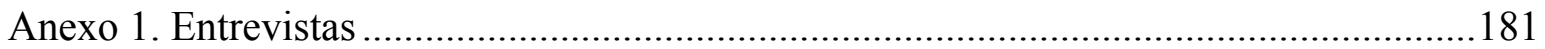

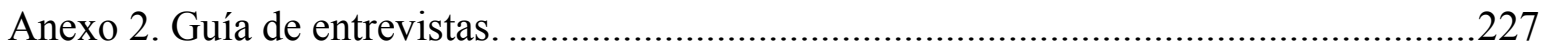




\section{Agradecimientos}

A la Universidad de La Plata, que hizo posible por medio de la Maestría en Estética y Teoría de las Artes el desarrollo de la presente investigación.

A mi director de tesis Emiliano Causa, y mi co-directora de tesis Silvia García por su infinita generosidad académica y humana.

A los artistas que participaron de la investigación y abrieron las puertas de su saber con generosidad y amplitud.

A mi esposa, compañera y amiga Claudia Elena Mesa por su solidaridad, comprensión y apoyo incondicional.

A mi hija María del Coral por su amor y colaboración permanente.

A mis compañeros de Maestría por sus valiosos aportes en estos dos años compartidos. 


\section{Resumen}

El presente documento es el resultado de una investigación realizada en el marco de la Maestría en Estética y Teoría de las Artes, de la Facultad de Bellas Artes de la Universidad Nacional de la Plata. Esta tesis intenta describir y analizar a través de un estudio cualitativo, centrado en los ejes instalación interactiva, instalación robótica, arte electrónico, y artista, las particularidades del rol del público en el contexto del arte electrónico en la ciudad de Buenos Aires, durante la década 2002 - 2012; pretendiendo dialogar con doce obras de arte electrónico seleccionadas y sus respectivos productores.

Este trabajo no buscó establecer categorías absolutas ni generalizables, sino propiciar una apertura a un tema complejo y de actualidad como es el del arte electrónico y su relación con el público. En este sentido, el estudio contrasto la información recolectada a través de entrevistas directas con los productores de las obras, el análisis de las mismas y los constructos teóricos que se han elaborado en torno al rol del público con relación el arte electrónico.

Palabras claves: arte electrónico, instalación interactiva, instalación robótica, interactividad, público.

\section{ABSTRACT}

This document is the result of an investigation carried out within the framework of the Masters in Aesthetics and Theory of the Arts in the Faculty of Fine Arts of the National University of La Plata. This thesis attempts to describe and analyze through a qualitative study the role of the public in the context of electronic art in the city of Buenos Aires. The axes used during the research were interactive installation, robotic installation, electronic art, the artist, and the particularities of the role of the local public during the decade 2002 - 2012. The intention was to establish dialogue with twelve selected electronic works of art and their respective producers.

This work did not seek to establish absolute or generalizable categories, but to promote an openness to a complex and current theme, such as electronic art and its relationship with the public. In this sense, the study contrasted the information collected through direct interviews with the producers of the works of art, their analysis and the theoretical constructs that have been elaborated around the role of the public in relation to electronic art.

Keywords: electronic art, interactive installation, robotics installation, interactivity, public. 


\section{Introducción}

"Las nuevas tecnologías virtuales son "quirúrgicas": revelan el mundo en nuestras representaciones, conmueven al observador con nuevas percepciones.” (Foster, 2001, pág.

Las prácticas y transformaciones que se sucedieron en el campo del arte a partir de las relaciones establecidas entre arte, ciencia y tecnología, así como en aquellas que emplearon los nuevos medios digitales, electrónicos y de las telecomunicaciones durante el siglo XX y específicamente las sucedidas desde la década de los sesenta, generaron variaciones notables en los procesos de creación y reflexión, tanto de artistas como de los teóricos del arte en diversa disciplinas como la historia, la sociología y la estética.

Los procesos de reflexión teórica y las prácticas artísticas han sufrido un proceso divergente desde los postulados modernistas del siglo XX hasta los planteamientos diversos de la posmodernidad. El crecimiento, desarrollo y propagación del uso de las tecnologías de la información y comunicación aplicadas al campo del arte revelan procesos de ruptura entre la praxis artística, la reflexión del arte, la estética y las maneras de relación entre creador, obra y público.

En los campos del arte, la ciencia, la tecnología y la estética se extiende una cronología de contradicciones respecto a presupuestos como los de autenticidad, corporeidad, y verdad. Se revisan los supuestos y postulados referidos a percepción, creación, representación, y público entre otros. Los vínculos cada vez más estrechos entre ciencia, arte y la construcción de nuevos paradigmas como arte interactivo, realidad virtual, multimedia, videojuegos, instalaciones interactivas, robóticas, páginas $W e b$ entre otros, son punto de inicio a nuevas maneras de relación e interdependencia en la triada creador, obra y público. 


\section{Motivaciones y propósitos}

El dislocamiento del rol del público hacia papeles y lugares nuevos tiene consecuencias notables en lo que generalizamos como público del arte. La institucionalidad cercana como museos y salas de exhibición deben reformular las convenciones de comportamiento tradicionales de dicho rol, al igual que el tradicional uso del espacio expositivo. El contacto directo con la obra en una relación dialógica y plural afecta tanto al espectador como a los creadores. Se investigan nuevas estrategias para incitar y detonar en el receptor nuevos comportamientos, posturas activas, y expresivas que lo involucren como parte sustancial y central del proceso de completitud de la obra. El papel de la interfaz es fundamental en la relación hombre-máquina-sistema, de ahí que se construyen formas disruptivas que subvierten los prejuicios respecto a lo que debe ser una obra de arte y lo que el público haría cuando esta frente a ella.

Desde la reflexión estética, la pregunta por lo objetivo, el receptor, el sujeto, o el usuario se amplia, se expande, o bifurca en múltiples dimensiones. Los conceptos estéticos centrados solamente en la obra como objeto principal se ven cuestionados abiertamente. El arte electrónico transforma los papeles; las relaciones tradicionales que se dan entre contexto y obra ya no son más componentes independientes de una diada pasiva-contemplativa, ahora se establecen nuevas relaciones y cuestionamientos a rasgos como la existencia matérica, la permanencia, la originalidad, la autoría, el consumo, la dimensionalidad y la temporalidad del fenómeno artístico.

El arte electrónico argentino ocupa un lugar central en las motivaciones que gestaron este proyecto de investigación. Las producciones electrónicas en general y en particular las instalaciones interactivas e instalaciones robóticas detonaron la participación del público en relación con los dispositivos tecnológicos puestos en escena; dispositivos que subvirtieron el rol del público tradicional y lo avocaron a relaciones múltiples y complejas, tanto con la propuesta instalativa como con el espacio expositivo.

A pesar de las conceptualizaciones en torno a la figura del público, parece ser que el concepto mismo se resiste a ser encasillado en una episteme singular o en un vocablo en particular y continúa siendo un concepto en proceso de construcción. Fue así como el acercamiento tanto a las instalaciones interactivas e instalaciones robóticas relevantes de algunos de los eventos más importantes del arte electrónico en la década 2002 - 2012 en la 
ciudad de Buenos Aires como a los artistas que las crearon, generó intuiciones que vislumbraron la expansión de dicho rol hacia nuevos horizontes, posibilitando tipificar su participación como usuario, actor e interactor, respectivamente.

A partir de esto se perfiló a manera de hipótesis que las obras de arte electrónico colocan al público como una variable activa, donde dicha categoría se resignifica según el lugar de emplazamiento que le adjudica el artista y/o la obra. El análisis del corpus seleccionado, ofrece evidencia suficiente para tipificar en la escena local de Buenos Aires del período comprendido entre 2002/2012, la configuración de roles en el público como los de usuario, actor e interactor.

La investigación indaga los diferentes modos de vinculación entre el público y el arte electrónico, específicamente en el ámbito de las instalaciones interactivas y robóticas. Procura asimismo contribuir al constructo teórico en circulación en los espacios de la academia y del público en general; para tal fin se trazó los siguientes objetivos:

1. Explorar el discurso teórico referido al arte electrónico y al rol del público con relación a la instalación interactiva y la instalación robótica

2. Analizar doce obras de arte electrónico exhibidas en Buenos Aires durante la década 2012-2012.

3. Entrevistar a los artistas productores de las doce obras a analizar.

4. Contrastar la información recopilada a través de las entrevistas con los constructos teóricos referidos al rol del público.

5. Identificar los diferentes modos de vinculación del público con las obras.

6. Constatar las posibles re significaciones de las nociones de público, observador, espectador y /o receptor. 


\section{Aspectos metodológicos}

El advenimiento de los nuevos medios en la escena del arte argentino particularmente en la ciudad de Buenos Aires, incorporó las llamadas nuevas tecnologías o tecnologías de la información. Este nuevo fenómeno generó diversas transformaciones que modificaron los distintos modos que intervienen en el proceso artístico como son los modos de producción, exhibición, circulación, recepción y consumo de las producciones artísticas. La relación ciencia-tecnología-arte impacta la escena local, el perfil de los artistas, y los espacios de exhibición entre otros. Los casos de análisis de obras electrónicas tratados, mostraron como la interdisciplinariedad y la participación de profesionales provenientes de diversas áreas en el proceso de producción fue requerida. De hecho, la relación entre el espectador y la obra se vio afectada de manera sustancial, en cuanto, tanto la obra como su recepción adquirieron una nueva dimensión relacional. Así, el rol en cuestión debe ser entendido como una construcción teórica que caracteriza, pero no define la totalidad de la realidad del fenómeno aquí estudiado.

La estrategia metodológica requirió entones analizar el lugar del receptor en las propuestas de Arte Electrónico en Buenos Aires durante el periodo comprendido entre 2002 - 2012. Este planteamiento implicó a su vez volver la mirada sobre el contexto de la escena del arte electrónico en Buenos Aires teniendo como base los principales eventos e instituciones que lo han favorecido y propiciado. Con respecto al termino arte electrónico, en el presente estudio se lo utilizó desde la dimensión que el artista Mariano Sardón plantea cuando dice de manera sucinta "Artes electrónicas son artes que incorporan tanto formal, material, como paradigmáticamente la electrónica al proceso artístico. Detrás de toda tecnología hay una mirada y construcción del mundo, y con ella operamos los artistas." (Sardón, 2005) Lo anterior sin excluir otras acepciones que serán citadas en el desarrollo de este escrito.

Los datos concretos que la presente investigación utiliza provienen de: entrevistas realizadas a los artistas productores de las obras seleccionadas a partir de un cuestionario flexible de preguntas en torno a la temática estudiada, información descriptiva recolectada a través de la Internet de las obras seleccionadas, catálogos de los eventos en los cuales se exhibieron las obras y el constructo teórico relevante en torno a la temática tratada. 
Se seleccionó para el presente trabajo un conjunto de instalaciones interactivas y robóticas que participaron en certámenes relevantes del arte electrónico en la ciudad de Buenos Aires:

1 Proxemia (2002/2008) de Mariela Yeregui.

2 Libros de arena (2004) de Mariano Sardón.

3 Calor, Humedad y Vapor. Turner en el Siglo XXI (2005) Marina Zerbarini.

4 Tango Virus (2006) de Grupo Biopus, Emiliano Causa, Tarsicio Pirota, Matías Romero

5 Alexitimia (2006) Paula Gaetano.

6 Propagaciones (2007) de Leo Núñez.

7 Los aparatos (2008) de Federico Joselevich, Julia Vallejo.

8 Sensible - Instalación interactiva - 2007 - de Grupo Biopus, Emiliano Causa, Tarsicio Pirota, Matías Romero

9 Espacio cambiario (2010) de Leo Núñez.

10 Efecto mariposa (2011) de Patricio González Vivo.

11 Generación de conciencia I de la serie @Agua_Y_Aceite (2011-2012) de Daniel Álvarez Olmedo, Diego Díez, Guido Villar.

12 Generación de conciencia II de la serie @Agua_Y_Aceite (2011-2012) de Daniel Álvarez Olmedo, Diego Díez, Guido Villar.

Los casos seleccionados correspondieron a obras de arte electrónico que participaron en los siguientes eventos:

1 Premios Fundación Telefónica MAMBA - Arte y nuevas tecnologías.

2 Tecnoescena: Festival Internacional de Teatro, Arte y Tecnología.

3 MediaLab del CCEBA.

4 Premio Vida 9.0

El acercamiento a estas obras se realizó a partir de un encuentro presencial con los artistas creadores de las obras, encuentro que tuvo como nexo para la conversación una matriz cuestionario de entrevista la cual propuso las dimensiones de análisis para el escrutinio de las obras. Desde lo metodológico, la matriz cuestionario no tuvo por finalidad encontrar evidencias taxativas, sino reflexionar y favorecer desde el diálogo con los artistas la generación de diversos puntos de vista, la producción de nuevas preguntas, y el 
distanciamiento necesario que permitió procesos de recorte, deconstrucción y síntesis en torno al rol del público.

Desde el constructo teórico en torno al arte electrónico se transitó por el enfoque de investigación cualitativo de tipo exploratorio textual y el análisis de casos, a partir de los cuales se procuró un acercamiento a la noción de público que subyace en los casos citados, en los discursos teóricos relevantes y en la visión de los artistas.

Se consideró las siguientes dimensiones de análisis con relación al rol del público confrontadas desde los testimonios de los artistas entrevistados:

1. Una dimensión teórica del discurso precedente referido al arte electrónico que pretendió un acercamiento exploratorio textual al rol del receptor de la obra y que se caracterizó o referenció por términos como: observador, espectador, usuario, interactor, actor y otros.

2. Una dimensión de análisis que dirigió la mirada desde diferentes lugares propios del arte electrónico a aspectos como: autoría, interfaz, interactividad, ciencia y tecnología, desde los constructos teóricos de los artistas y recolectados a través de entrevistas directas con ellos.

3. Una dimensión de análisis centrada en las obras seleccionadas y vistas desde las referencias textuales de los catálogos y textos curatoriales.

4. Una dimensión de análisis a partir del testimonio de los artistas creadores de las obras seleccionadas. 


\section{Capítulo 1 Contextos}

\subsection{Contexto Arte, Ciencia y Tecnología}

El devenir de arte, ciencia y tecnología históricamente fluctúa entre aproximaciones, divergencias y convergencias. Su evolución ha sido en cierta manera coordinada. Los adelantos en cada uno de estos campos han potenciado desarrollos en los otros, razón por la cual sus procesos han sido sinérgicos y representan campos diversos en el contexto humano. Algunos de estos campos están relacionados y comparten elementos que los hacen cercanos. Lo que inscribe en un principio sus diferencias, son los métodos que utilizan para llegar a su objetivo final, ya sea un producto, un servicio, una obra o una solución a una problemática particular. Las distancias aparentes entre ellos ya no están delimitadas con un perímetro definido. Sus métodos se favorecen en una especie de altruismo unos a otros.

Reconstruir la traza de dichos conceptos no es el propósito en este apartado. Sin embargo, se requiere para efectos del estudio llevado a cabo, señalar someramente algunos momentos acaecidos en el trayecto histórico. Un primer estadio en el cual se deslinda progresivamente artesanía y arte, un segundo momento de instrumentalización en el cual los métodos, objetivos y procesos se diferencian adquiriendo cierta delimitación clara entre ciencia, arte, tecnología y finalmente la declaratoria de autonomía dada por el arte a partir de la revolución industrial.

En la antigüedad clásica particularmente en Grecia alrededor dl siglo IV A.C, se instaura desde la filosofía una diferencia marcada entre los procesos productivos manuales y los conocimientos logrados por procesos de educación y formación. Los términos tékhne y mousiké se emplearon para denotar tal diferencia. La tékhne término utilizado para designar puntualmente la producción manual de objetos a partir de habilidades, destrezas y conocimientos. Escultura y pintura al igual que muchas actividades consideradas hoy en día artesanías se las consideró dentro del ámbito de la tékhne. La música, la danza y la poesía se congregaban bajo el termino mousiké. La diferencia según se constata en los diálogos platónicos radicaba en que la tékhne implicaba desarrollos manuales, utilización de herramientas y un dominio técnico sobre las materias utilizadas. A diferencia de la anterior la mousiké como es el caso de la poesía y la música se la consideró como de inspiración divina pertenecientes a una categoría superior del conocimiento. 
"En su sentido amplio, «arte» se referiría a cualquier habilidad humana, ya sea poder (o saber): escribir un poema, hacer un recipiente de cerámica o predecir un fenómeno natural. En su sentido restringido, en cambio, «arte» designaría cierta clase especial de habilidades o «productos» (las obras de arte), tales como la pintura, la escultura, la música, la danza, etc. y la capacidad técnica para diseñar, componer o ejecutar semejantes objetos.” (Herrero, 1988, pág. 114)

Previo al Renacimiento no hubo separación entre arte y artesanía. Los objetos fabricados no tuvieron una finalidad meramente de contemplación. Uso y función fueron parte inseparable en el proceso de fabricación. Desde lo tradicional los criterios estéticos aplicados fueron en relación al cumplimiento de la función, el punto de contemplación y el deleite en la vida.

Las distinciones en la terminología que aparecieron en algunos diálogos platónicos referida al arte, la técnica y la ciencia se sostuvieron por mucho tiempo y fueron utilizadas en el siglo XVIII en las discusiones teóricas que de manera gradual sostuvieron la liberación de las artes de otras prácticas intelectuales. Es así como la expresión Bellas Artes surgió a partir del siglo XVIII, momento en el que no se había establecido la taxativa separación entre ciencia y arte. Charles Batteux, publicó Las bellas artes reducidas a un único principio en 1746, fue el primer libro que se conoce que clasifica las bellas artes. incluyó entre las bellas artes a la danza, la escultura, la música, la pintura y la poesía, para luego añadir la arquitectura y la elocuencia.

Arte y artesanía se empiezan a deslindar a partir del siglo XII en los procesos de construcción medievales en un primer estadio; luego a causa del distanciamiento entre ciencia, arte y técnica que se produjo en la llamada revolución industrial. Métodos, finalidades e instrumentos se encuadran en función tanto del pragmatismo tecnológico, como del racionalismo científico y el humanismo que se expresó en el arte.

El siglo XIX augura el advenimiento de desarrollos como la fotografía, el cine, el telégrafo y la bombilla eléctrica. ${ }^{1}$ Cada uno de estos inventos pone en cuestión tanto el

\footnotetext{
${ }^{1}$ A finales del siglo XIX, la luz eléctrica y la telefonía ya eran populares en los centros urbanos y en la década de 1910 entraron en el mercado electrodomésticos como aspiradoras, lavadoras y refrigeradores. En cuanto a la radio, su mercado explotó en los años veinte junto con el crecimiento de transmisiones comerciales. Por su parte, las tecnologías que fueron
} 
universo de lo artístico como el tecnológico. Las discusiones en torno al arte, la ciencia y la tecnología adoptan posiciones extremas. Por ejemplo, los llamados decadentistas como William Morris y John Ruskin fundadores del movimiento Arts and crafts propusieron regresar a la manufactura artesanal en oposición a la producción serial de la época y así llegar a las áreas menos favorecidas de la sociedad. Sin embargo, sus objetos fueron tan complejos en su elaboración que solo algunos privilegiados pudieron adquirirlos.

La fotografía fue adoptada por artistas de la época como Courbet y Millet quienes en su búsqueda realista encontraron en ella un apoyo válido para sus procesos creativos, por el contrario, Baudelaire en alguno de sus escritos la criticó y afirmó que es el refugio de los pintores mal dotados, sin genio y perezosos. Walter Benjamin destacó como la fotografía cuestionó a la pintura de manera directa en cuanto a sus propositivos representativos: “...en el preciso instante en que Daguerre logró fijar las imágenes de la cámara oscura el técnico despidió en ese punto a los pintores.” (Benjamin, 1989, pág. 45) Las vanguardias acogieron favorablemente los desarrollos tecnológicos, científicos y no dudaron en incorporarlos en sus propuestas. La Bauhaus se propuso encontrar la convergencia entre artes, arquitectura, artesanía y diseño, así propició la interdisciplinariedad.

Se evidenció en el devenir histórico el dialogo y la mutua correspondencia entre arte, ciencia y tecnología. Los desarrollos de cada uno de estos campos propiciaron desarrollos y adopciones creativas en los otros. Es así como diversos hechos establecieron puntos de unión y relación, como fueron el descubrimiento de la pintura al óleo, la utilización de la cámara oscura, los desarrollos de las matemáticas y la geometría en el Renacimiento, la teoría de la gestalt, la cibernética, el ordenador y todos los nuevos medios.

En síntesis, las relaciones entre arte, ciencia y tecnología en artistas e intelectuales generaron ideales estéticos y utopías. Las vanguardias artísticas en el siglo XX vieron en los desarrollos científicos y tecnológicos posibilidades para el cambio político y social, así como una manera para la transformación del arte y las personas. En los sesentas el arte tecnológico se revitalizó. Los artistas buscaron en él nuevas vías de acercamiento al mundo

desarrolladas durante los años difíciles de la Segunda Guerra Mundial aceleraron otra corriente de consumibles electrónicos durante la prosperidad de los tiempos de paz. La televisión se volvió enormemente exitosa en los años cincuenta, mientras que los 60 y 70 trajeron sistemas de sonido estéreo de alta fidelidad, videocámaras, control remoto, televisión por cable, y transmisiones vía satélite. En los 80 y 90 llegaron la computación personal, el acceso público a Internet, las capacidades multimedia de la World Wide Web, Internet de banda ancha y los teléfonos móviles, ocasionando el boom del comercio electrónico, impulsando la globalización e inundando los mercados globales con un diluvio de consumibles electrónicos sin precedentes. (Shanken E. A., 2013, pág. 8) 
sin la urgencia de cambiarlo. El advenimiento del video y los ordenadores favoreció la producción, y generó circuitos propios. El bit se expandió hacia el ciberespacio y las producciones audiovisuales exploraron nuevas estéticas. La electrónica introdujo posibilidades totalmente novedosas de manipulación, transformación y creación de realidades nuevas en las cuales el público en su papel de receptor adquirió nuevos roles. ${ }^{2}$

\footnotetext{
${ }^{2}$ Análogamente a lo que ocurrió a finales de los 60 y 70, cuando la práctica artística solicitó tecnología y se miró hacia las universidades, en los 90 y 2000 los principales artistas también buscaron contextos colaborativos en universidades con el objetivo de explorar el potencial de la investigación transdisciplinar basada en la práctica. Este tipo de investigación desafía los límites de la investigación y educación tradicionales, generando productos y practicantes híbridos. A medida que el número de estos practicantes aumente, su impacto en la importancia de la ciencia y tecnología para la producción de diseño y arte (y viceversa) forzará una reconsideración de los cánones establecidos en las historias del arte, de la ciencia y de la tecnología. Idealmente, este trabajo traerá nuevas formas y estructuras de significación que expandan los lenguajes del arte, diseño, ingeniería y ciencia, abriendo nuevas perspectivas a la creatividad e innovación. (Shanken, 2014. P. 107)
} 


\subsection{Contexto estético}

La modernidad produce cambios profundos en la condición del individuo, sus relaciones, las maneras de ver el mundo, el resquebrajamiento de la realidad objetiva, la relatividad de las ciencias además propicia un horizonte abierto, flexible, dinámico para la reflexión y el diálogo entre las ciencias y las disciplinas. En el siglo XX se favorece la confrontación entre racionalismo y relativismo teniendo como ejes de discusión las nociones de verdad, razón, saber y poder. Muchos de los bordes de las disciplinas se desdibujan generando dinámicas de expansión y entrecruzamiento entre las ciencias y las disciplinas. Los estudios en torno a la información y la comunicación evidencian el cruce y aparición de la cibernética, la electrónica, y los nuevos medios. Los soportes tecnológicos desarrollados se constituyen en herramientas que inciden en la cultura y provocan cambios profundos en el arte. La revolución informática replantea las relaciones entre los individuos de tal forma que imágenes, formas audiovisuales y contenidos culturales plantean otro tipo de relaciones en entornos interactivos, en los cuales la estética se constituye en un factor importante que reclama nuevas formas de reflexión y expresión para los fenómenos expansivos que se producen desde el arte electrónico.

\subsubsection{El control}

La revolución industrial ocurrida en el siglo XIX dio un gran impulso a los múltiples desarrollos tecnológicos que ocurrieron a la par que los procesos de mecanización y posterior automatización. James Beniger traza el origen de la llamada Sociedad de la información. (Beniger, 1989) Establece una relación entre las aplicaciones que surgieron a partir del uso de la energía del vapor en el 1800 y el dramático incremento de la velocidad, los volúmenes y complejidad de los procesos industriales. La crisis que estas aplicaciones desencadenaron dieron origen a lo que el Beniger llama "The Control Revolution." La manifestación de esta crisis se reflejó a diferentes niveles: problemas con los envíos de mercancías, con los horarios, y con el manejo de inventarios entre otros. Por consiguiente, el advenimiento de las nuevas aplicaciones y usos de la energía al vapor requirió mejores desarrollos en el manejo y uso de la información. 
Entre los años 1840 y 1920 surgió la mayor parte de las tecnologías de procesamiento de la información y la comunicación aún hoy en uso, como la telegrafía, el teléfono, la fotografía, el cine, la litografía offset y más recientemente los microprocesadores, los ordenadores y las telecomunicaciones que son solo una suave continuidad de esta llamada revolución del control que dio origen a la teoría cibernética.

La revolución del control impactó directamente los modos de reproducción cultural, el ámbito del arte y las comunicaciones. Las teorías cibernéticas se enfocaron entonces hacia el estudio de las nuevas relaciones establecidas entre el hombre y la máquina, entre los sistemas biológicos y los tecnológicos. Norbert Wienner planteo en su libro Cibernética y sociedad:

“...solo puede entenderse la sociedad mediante el estudio de los mensajes y de las facilidades de comunicación de que ella dispone y, demás, que, en el futuro, desempeñaran un papel cada vez más preponderante los mensajes cursados entre hombres y máquinas, entre máquinas y hombres y entre máquina y máquina." (Wiener, 1958, pág. 16)

N. Wiener introdujo desde sus postulados referidos a la cibernética una nueva invariante, a saber: el remplazo o sustitución del concepto de energía por el de información como parámetro comunicacional. A partir de las líneas de pensamiento fundamentadas en las teorías referidas a la Cibernética, e igualmente a lo que se ha denominó inteligencia artificial, entendida como la posibilidad de desarrollar maquinas o autómatas que puedan proceder de manera análoga al sistema nervioso o al cerebro, se encontró que la información y las teorías referidas al medio y al mensaje fueron una clave para la comprensión de los procesos estéticos desde el campo comunicacional y cibernético. Es así como se abre paso en los años treinta un discurso que trata de la teoría estética, los procesos de formalización, y el arte electrónico. 


\subsubsection{Estética informacional}

En la relación que se establece entre teoría estética, arte electrónico y el uso de las computadoras, es necesario una mirada a las denominadas estéticas informacionales. Aquello que se conoce como "estética de la información” demuestra el interés marcado por establecer una relación entre el arte como parte de las ciencias humanas, con las ciencias matemáticas y físicas, aproximando la estética a una pretensión cientificista de marcado carácter racionalista.

En referencia directa a las posibilidades del arte y las computadoras escribió Herbert W. Franke:

“Adviértase, no obstante, que la producción de grafos con computadoras no exige una teoría estética: basta realizar programas que tengan en cuenta una serie de reglas impuestas por el artista. Aunque también los programas pueden realizarse a partir de una estética concebida de forma teórica.” (Franke H. W., 1970, pág. 16)

Se intuía la posibilidad de relacionar la reflexión estética con los desarrollos que provenían del uso del ordenador, situación que provocó una mirada desde la estética hacia el componente formal de la comunicación y de los lenguajes binarios.

Los dos principales teóricos fundacionales de la estética Informacional fueron, el alemán Max Bense y el francés Abraham Moles. Dada la riqueza y complejidad de su producción intelectual se hace necesario hacer algunas consideraciones con respecto de ellos.

Max Bense, filósofo, matemático y teórico sobre semiótica, propuso a mediados de los años 1950 una visión de la estética desde la perspectiva de las teorías de la información y la comunicación, hizo referencia a los signos y significados como componentes que constituyen la obra de arte. Su mayor contribución consistió en el enfoque semántico con que relacionó lo estético y lo comunicacional. Sus escritos indagan en la filosofía, el arte, la estética, la cibernética, la comunicación, y la semiología. Estuvo influenciado por autores como Charles Peirce, Charles Morris, Abraham Moles, Norbert Wiener, y algunos teóricos funcionalistas de la comunicación como Claude Shannon. Bense propuso objetivizar la estética, operacionalizándola no con medios especulativos sino racionales, de ahí que habló de estética matemática y estética tecnológica. Planteó entonces una estética empíricoracional de la comprobación, con base en significados y estructuras. El arte se constituye de información y "estados estéticos", observables en cifras y clases de signos. La "estética de la 
información", se basa, en medios matemáticos y semióticos, que permiten el acercamiento y análisis a la obra de arte. Investigó las formas generadas por computador, centrándose en las denominadas estéticas numéricas, estética semiótica y estética generativa. La estética numérica propuso el estudio de las estructuras sintácticas de las obras a partir de análisis estadísticos de las mismas. Bense distinguió entre los elementos matéricos de las obras como la ordenación del color y las geometrías o formas sobre la superficie y la relación entre sí en términos de la complejidad y el orden. Entre el orden, la redundancia, la innovación, y la información existen unas determinadas relaciones numéricas que la estética tiene como objeto clarificar. La de mayor trascendencia sería que, en cualquier producto artístico, en el cual disminuye la entropía en beneficio del estado estructural aumenta necesariamente el orden en menoscabo de la información. Dicho de otro modo: "La ganancia de orden se revela como pérdida de información, es decir, con el crecimiento de orden (de los elementos) previsible de un estado estético disminuye su innovación, su originalidad." (Santana, 2007, pág. 25)

La estética semiótica, en Bense identifica las relaciones formales entre los signos, las relaciones entre los elementos del repertorio material con el que se construye un objeto artístico, y así los signos se muestran como auto reflexivos. De esta manera, los signos, inseparables del significado, se convertirían en informaciones, una interpretación del concepto estético como proceso informacional.

La estética generativa, es un desarrollo superior del proceso de investigación de las formas y creaciones elaboradas desde el computador. Bense en los años 1960, definió: "Por estética generativa hay que entender la suma total de todas las operaciones, reglas y teoremas, que aplicados a un repertorio de elementos materiales manipulables pudiesen producir en este, de un modo consciente y metódico, estados estéticos." (Bense, 1973), referenció el proceso creativo en dos fases, una fase de concepción e idea de la propuesta artística y una segunda fase de realización o fase técnica. En la fase última, el artista crea un orden estructurado a partir del cual se establecen relaciones entre elementos pre-existentes los cuales se generan y sintetizan en variedad de formas simbólicas, plásticas, literarias y o musicales. Se debe anotar que todo este fenómeno es un proceso virtual a través del cual se crean los elementos que producen el objeto artístico. Al respecto sobre esta tendencia estética dice S. Marchán " $E l$ objetivo especial de esta rama desde la perspectiva de la estética de la 
información es el estudio de la elaboración operativa y numérica de sistemas sígnicos, de su génesis regularizadora y reflexión científica.” (Marchan, 1986, pág. 135)

A la par que Bense desarrolla sus teorías centrado en las Artes plásticas, Abraham Moles fundador igualmente de la estética informacional se centra en la música, la lingüística y el incipiente arte electrónico. Moles va más allá de la visión cientificista de la estética planteada por los racionalistas que se centraron en el concepto de mensaje. Entre los exponentes de estas teorías está el matemático David Birkhoff quien pretendió objetivar a partir de reglas los procesos de valoración estética de la obra de arte. Moles duda de los procesos de legitimación de la verdad sobre la base de postulados cientificistas. El observó la crisis de la ciencia en términos de su racionalidad teórica. En ese sentido se orienta ya en una línea de lo que serían las tendencias posmodernas.

En su acercamiento reflexivo en torno a la relación máquina-hombre, vislumbró la relación máquina-arte, maquina-artista, máquina-espectador. Consideró que las maquinas son sistemas que operan con capacidad creativa a partir de la combinatoria de elementos, estructuras y programas. Intuyó el poder de simulación que los computadores potenciaban dadas sus posibilidades combinatorias, de almacenamiento, memoria y procesamiento de datos. La simulación, el simulacro a partir de la máquina, permiten la copia, ya no como una copia exacta de un original sino como una reproducción siempre nueva de un proceso que incluso podría bifurcar reiterativamente. Las nociones de original, verdad, incluso de autor y receptor de la estética clásica pierden valor y se centran en la operatividad que la maquina potencia. Dice Claudia Giannetti "Por consiguiente, damos con un punto primordial para la reflexión sobre el media art, que cobrará más peso casi treinta años después, a finales de los años ochenta: La sustitución del concepto "verdad" por el de "simulacro"." (Giannetti C. , 2002, pág. 38). En sus planteamientos Moles identificó las estrechas relaciones entre tecnología y criterios de verdad. En el surgimiento de las nuevas tecnologías los criterios de operatividad y eficiencia están a la orden del día. En ese sentido años después Jean-François Lyotard afirmó "La condición postmoderna es, sin embargo, tan extraña al desencanto, como a la positividad ciega de la deslegitimación. ¿Dónde puede residir la legitimación después de los metarrelatos? El criterio de operatividad es tecnológico, no es pertinente para juzgar lo verdadero y lo justo.” (Lyotard, 1998, pág. 5) 
Desde las teorías planteadas por Moles en su libro Cibernética y obras de arte, la relación hombre-máquina proyectó la posibilidad de que las máquinas produjeran arte con base en procesos de simulación y o creación intelectual. A partir de esto, moles, visionó a un artista programador y a la vez esteta en tanto delimita el proceso creativo, al hacer una traducción de categorías al plano del simulacro de la copia. Moles propuso cinco maneras de programar para la generación de obras artísticas: el amplificador de capacidad; la máquina imaginativa; el arte permutacional, el observador artificial y el modelo protésico. Sus teorías y planteamientos dirigieron en su momento la mirada hacia el foco del arte electrónico en cuanto a la función del artista, el concepto arte y el rol del público. En particular Moles prevé el advenimiento de un espectador consumista y alienado frente a la producción masiva de objetos y productos culturales. Los grandes postulados de la estética clásica referidos al orden y la proporción, asumidos en la tradición subjetivista kantiana y romántica como un plano emocional de lo bello que se adhiere al sentimiento y en ninguna instancia a la producción de conocimiento. El relato ordenado y proporcionado acerca de la belleza, seden su lugar en la estética informacional, a procesos de cálculo de probabilidades e interacciones, Al respecto Claudia Giannetti afirmó "Realizan, por lo tanto, un proceso de des-subjetivización de los criterios de belleza, puesto que sus valores pueden ser calculados por una máquina independientemente de la apreciación calológica.” (Giannetti C. , 2002, pág. 42). 


\subsubsection{Estética cibernética}

Posterior a las teorías de Max Bense y Abraham Moles referidos a la estética informacional, se continuó desarrollando tanto el corpus teórico como la práctica artística en torno a los nuevos medios y las tecnologías de la información. (Wiener, 1958) en su libro Cibernética y Sociedad, desarrolló la tesis en la cual sostuvo que para comprender la sociedad se requería del estudio tanto de los mensajes como de las facilidades de comunicación de que ella dispone. Y que en el futuro serán de suma importancia los mensajes cursados entre hombre y máquina; máquinas y hombre; y entre máquinas y maquinas, dibujó el escenario cibernético.

Herbert Franke; Helmar Frank y Siegfried Maser alumnos de Max Bense dieron continuidad a la investigación acerca de la estética informacional. El aporte de Moles referido a la interrelación entre el estudio de la percepción y la teoría de la información, originó lo que se llamó la Sicología de la información, que fueron el soporte de sus teorías estéticas. Desde esta nueva disciplina en los años 1979, el concepto de espectador pasivo y contemplativo quedó desvirtuado en tanto que la obra de arte es tratada como un objeto de comunicación y como tal se relaciona con el espectador desde su condición de receptor activo y participante. Surgió entonces la defensa de los estados o circunstancias subjetivos que constituyeron el fundamento de la corriente humanista de la Cibernética Antropológica y Humana, que tuvo por principal exponente a Hermann Schmidt. "Es así como Herbert Franke propuso el término Estética Cibernética en el ensayo Arte contra técnica.” (Santana, 2007, pág. 34).

La estética cibernética de H.W Franke indagó en el entrecruzamiento de la Teoría de la Información, la Teoría de la Percepción y la Neurología. En el artículo Arte contra Técnica, ponderó la importancia de los procesos de percepción en la construcción de la información estética. Consideró fundamental para los procesos del arte basado en los nuevos medios, la utilización de elementos estéticos tecno-científicos provenientes de la lógica, la matemática, la programación o la ingeniería, los cuales no se contemplaron en los desarrollos artísticos tradicionales. Se presentó entonces la estética cibernética como un paradigma de los cruces entre ciencia, arte y tecnología. (Franke H. W., 1995, págs. 50-61) La estética cibernética introdujo conceptos referidos a la participación del público en las propuestas de arte electrónico, así como los sistemas interactivos que se desarrollaron posteriormente. 
En el año 1967 se publicó el primer manual de Estética Informacional. H.W Franke fue el contribuyente decisivo para la estética cibernética. Al introducir el concepto de sistemas interactivos y de la participación del público en la obra, indaga en una dimensión ignorada por Bense "...el aspecto no mensurable de la experiencia vivida por el espectador en el proceso de percepción y comprensión de la obra de arte.” (Giannetti C. , 2002, pág. 44)

Las estéticas Informacional, Generativa y Cibernética, tuvieron en común la característica del parámetro información como componente clave para el acercamiento a los procesos estéticos. Estas concepciones propusieron la formalización del lenguaje artístico a partir de normativas y propósitos cientificistas, sin embargo, su proyecto se convirtió en una utopía. 


\subsubsection{Endoestética}

El desarrollo científico ocurrido a partir del siglo XIX, trastocó diversas nociones de realidad que se habían edificado hasta entonces. Las teorías electromagnéticas, termodinámicas y relativistas auguraron un nuevo horizonte para la ciencia el arte y la tecnología. Simultáneamente todo el constructo filosófico y estético se renovó en diversas vertientes, entre las cuales las estéticas informacionales darían cuenta del fenómeno de la comunicación como parámetro informacional y a partir del cual la reflexión en torno a los nuevos medios y los procesos generativos a partir de algoritmos estarían a la orden del día. En las últimas décadas desarrollos científicos como la teoría del caos, disipativas y otras, cuestionaron el papel del observador en torno a su capacidad de observar el mundo del cual participa.

La endofísica investigó la relación entre el observador y el sistema del cual hace parte. Bifurca en dos posibilidades, la del observador como parte interna del sistema y la contraria como la de un observador externo al sistema del cual hace parte. Se preguntó la endofísica por si son posibles otras perspectivas diferentes a la del observador interno. Si el observador es tan solo un habitante del interior del sistema al cual pertenece. Se pregunta por el concepto de objetividad en el sentido clásico. Desde los postulados de la Endofísica, el observador es el constructor de la realidad objetiva. Ya en el pasado se acordó desde el siglo XV como el punto de vista del observador es fundamental en la construcción del espacio representado en el plano. Se conoce que la fenomenología de la realidad depende del lugar del observador en el mundo. Dar cuenta objetiva y completa del fenómeno estudiado requiere un observador externo de él (teorema de la indefinición de Gödel). De lo anterior se dedujo que tal situación del observador es solo posible en cuanto modelo, eterno del fenómeno complejo, no en el interior del mundo observado o vivenciado.

La endofísica se desarrolló a partir de la teoría cuántica y del caos a la que Lorentz Rössler, y otros contribuyeron, sobre todo se fija en el famoso Atractor Rössler de 1976. Igualmente, los desarrollos de la física cuántica y la teoría de la relatividad introdujeron de manera sistemática y paradigmática el asunto del observador como variable que trastoca todo el constructo teórico de la mecánica newtoniana. Así, surgió una miranda en la cual, los fenómenos físicos de lo que uno está observando suelen ser diferentes de las leyes extraídas desde una perspectiva externa imaginaria o real. 
La endofísica posibilitó un acercamiento en doble dirección a los fenómenos estudiados, de un lado el acercamiento desde los sentidos y del otro desde una posición imaginaria. Se concretó entonces la posibilidad de una visón exo y otra endo en relación al mundo de los fenómenos. Los desarrollos tecnológicos dieron realidad a la computarización de modelos y generación de realidades simuladas, a partir de las cuales el observador puede adoptar un punto de vista fuera del universo observado y aproximarse a una observación completa del mismo. La creación de interfaces y su relación directa con el observador es lo que ha permitido dilatar la frontera que limitan nuestro mundo.

El arte electrónico que se configura a partir de la década de los cincuenta, configura interfaces que permiten al observador experimentar y sumergirse en el mundo virtual en su doble rol, desde adentro y desde afuera. El tránsito de un público externo separado de la obra, así como el de la obra de arte ontológicamente como criterio de verdad, se desvanecen a partir de los procesos participativos e interactivos que conforman en parte la naturaleza del arte electrónico. Dice Peter Weibel en su ensayo El mundo como interfaz:

"El arte electrónico desplaza el arte desde un estadio centrado en el objeto a un estadio dirigido al contexto y al observador" plantea que el arte electrónico desplaza al arte desde un estadio centrado en el objeto a un estadio dirigido al contexto y al observador. De este modo, se convierte en un motor de cambio que lleva de la modernidad a la postmodernidad, esto es, tiene lugar una transición desde sistemas cerrados, definidos por la decisión y completos, a sistemas abiertos, no definidos e incompletos; desde el mundo de la necesidad a un mundo de variables manipuladas por el observador, desde la mono perspectiva a la perspectiva múltiple, desde la hegemonía al pluralismo, del texto al contexto, de la localidad a la no localidad, de la totalidad a lo particular, de la objetividad a la relatividad del observador, de la autonomía a la covariación, de la dictadura de la subjetividad al mundo inmanente de la máquina." (Weibel, 2000, pág. 24)

C. Giannetti, en sus reflexiones en torno a la endofísica, propuso el término Endoestética, “...la cual debe ser vista como un modelo teórico, que desde una posición interdisciplinar, pretende proporcionar las nociones básicas para entender y analizar estos 
cambios y las producciones actuales que se sirven de las posibilidades creativas brindadas por los nuevos recursos tecnológicos interactivos." (Giannetti C. , 2002, pág. 184)

Autorreferencialidad, simulacro, simulación, y virtualidad en tanto desmaterialización son apoyos que sustentan la Endoestética como un sistema de reflexión en torno a modelos de mundo surgidos de sistemas interactivos sobre los que se soporta creaciones interactivas.

El arte electrónico implicó una profunda transformación en la relación entre productor, público y obra. Desde la Endoestética, referida a los productos del arte interactivo y al espectador en particular se confirió estatus de interactor interno a quien participa en la creación de mundos virtuales que simulan o juegan con el simulacro, con la ilusión de traspasar la interfaz hombre-máquina, de manera tal, que los interactores fluyen entre dos realidades, una la de su ser consiente y la otra como artífice de la obra por su participación y actuación en el mundo simulado. Los objetos virtuales permiten el tránsito desde afuera hacia adentro; el concepto de participación extrínseca cede al de interactor que participa intrínsecamente y se relaciona con la obra de manera interdependiente.

A manera de síntesis del capítulo referido al contexto estético, se hizo un recorrido por las estéticas más representativas en torno a los sistemas interactivos como son la Estética Informacional con sus variables Numérica y Semiológica, la Estética Cibernética y la Endoestética, lo anterior sin pretender un tratamiento exhaustivo de tan complejo tema, sino por el contrario, lograr una aproximación al fenómeno tratado. Quedó claro como el parámetro informacional juega un rol crucial para el acercamiento y comprensión de los procesos estéticos del arte electrónico. Estéticas que buscaron con los procesos de formalización ampliar el horizonte contraponiéndose a las teorías subjetivistas de orden kantiano. Si bien es cierto, las teorías estéticas basadas en el componente comunicacional se quedan cortas en tanto pretendían mensurar el componente estético, también es cierto que abrieron la brecha para el análisis y la reflexión en torno al arte electrónico, así como a los cambios radicales introducidos por las nuevas tecnologías, los planteamientos técnicoartísticos, las relaciones entre creadores, público y obra; universos que implicaron cambios sustanciales respecto a la comprensión de las producciones que se enmarcaron en la tendencia del llamado arte electrónico, de ahí que la propuesta de Endoestética sea un proyecto en construcción sobre el cual es posible reflexionar para adentrarnos en el camino hacia la 
tipificación de los diversos roles que el público faceta en su interrelación con las obras de arte electrónico y en particular con las instalaciones interactivas y robótica analizadas en el presente estudio. 


\section{Capitulo 2 Antecedentes de las artes electrónicas en Buenos Aires}

La relación entre ciencia tecnología y arte ha estado presente en la historia del arte argentino. Las aproximaciones de luz y movimiento de los años 1940 se sintetizaron en la aventura Concreta-Madí-Cinética y se expresaron en el Manifiesto Invencionista, creado por Tomás Maldonado; manifiesto en el cual se afirmaba según Cayetano Iturburu Córdova en el libro 80 años de pintura argentina:

"La era artística de la ficción representativa toca a su fin(...) La estética científica reemplazará a la milenaria estética especulativa e idealista(...) El arte concreto habitúa al hombre a la relación directa con las cosas y no con las ficciones de las cosas. A una estética precisa, una técnica precisa. Ni buscar ni encontrar: inventar." (Córdova, 1978, pág. 146)

Dicho manifiesto vislumbra el cruce de la ciencia con el arte y la clara intención referencial de los artistas por una estética anclada en los presupuestos de la modernidad. "En este sentido el desarrollo de las experiencias de Kosice, desde sus articulables madís a las esculturas hidroespaciales establecen el cruce de investigaciones visuales y poéticas del nuevo arte que marca un momento central en los años '60." (De Rueda, 1999)

Las diferentes manifestaciones que se desarrollaron a partir de1960, transitaron por lo cinético, el video arte, acercamientos el cine expandido, así como la utilización de dispositivos mecánicos, eléctricos y electrónicos, luces, nuevos sustratos, proyecciones, sonido, y ordenadores. Dichas manifestaciones surgieron en las obras y reflexiones de los artistas, motivados por condiciones propicias a través de un diálogo con las tendencias internacionales. La producción de éstos años bifurca en relatos experimentales y en la proposición de híbridos que mezclan lo visual, lo sonoro y el movimiento, los cuales tiene por soporte el componente tecnológico.

En su ensayo Arte y tecnología en Argentina - los primeros años -, Rodrigo Alonso hace una referencia a la imagen electrónica y los comienzos del video arte. A continuación, un par de referentes al respecto tomados de dicho ensayo: "La historia del video arte en Argentina comienza en 1966 con Simultaneidad en Simultaneidad. Existe, sin embargo, un importante antecedente en la Menesunda, una ambientación de Marta Minujin y Rubén Santantonin" (Alonso, Arte y tecnología en Argentina - los primeros años, 2005), es en este 
proyecto en que lo electrónico adquiere un papel preponderante, lo que permite la consideración de ser pionera en el arte electrónico:

"Esa obra incluyó, posiblemente, el primer circuito cerrado de televisión de la historia del arte. Ese circuito cerrado estaba ubicado entre monitores que transmitían la programación habitual: el visitante era confrontado así con su propia imagen formando parte del discurso fragmentado de la televisión." “...David Lamelas presentó Situación de Tiempo, una sala iluminada por diecisiete televisores que transmitían ruido de señal y sonidos vagos. La instalación llamaba la atención sobre la naturaleza temporal del medio electrónico. Esta obra se relacionó con otra de 1968, donde Lamelas dispuso en una sala dos proyectores de diapositivas que solo proyectaban luz, condición de posibilidad de la imagen cinematográfica. En 1969, otras dos piezas volvían a utilizar la imagen electrónica: Especta, del Grupo Frontera y Fluvio Subtunal de Lea Lublin." (Alonso, 2005)

Al final de la década de los sesentas particularmente el año sesenta y nueve, se cierra los procesos experimentales relacionados con el pop, los happenings y los nuevos medios incipientes asociados y legitimados por el Instituto Di Tella. El Centro de Arte y Comunicación - CayC - , fundado por Jorge Glusber impactó la escena del arte de Buenos Aires en los años setentas. Las actividades que en dicho centro se llevaron a cabo manifestaron la intención de acentuar las condiciones materiales de producción de la obra, el acceso a la tecnología y las condiciones de objetivación de lo político. Los procesos de creación y producción de la obra adquieren importancia y se constituyen en el centro mismo del interés de los artistas ya no sus resultados finales, planteamiento que se puso de relieve en el mainstream de la época. Los planteamientos teóricos y el lenguaje propio de las propuestas se sitúan en una línea de discusión que genera bases para articular el componente social de la época favoreciendo la denuncia y la expansión de lo local a lo global.

El proyecto del Centro de Arte y Comunicación se caracterizó por ser interdisciplinario y experimental, continuando de alguna manera con la tarea vanguardista del instituto Di Tella. Particularmente la ola de las innovaciones tecnológicas de los 70's en el área de las Tics se ve inmediatamente reflejada en la muestra Arte y Cibernética la cual reunió ingenieros, programadores y artistas tales como Antonio Berni, Rogelio Páleselo, Gregorio Dujovny, Eduardo Mac Entyre, y Josefina Robirosa. La conexión de lo local con lo 
global se da en la medida que dicha experiencia interdisciplinaria se cruza con la invitación de artistas internacionales de Inglaterra, Estados Unidos, Japón en la Galería Bonino, para luego insertarse en el circuito internacional durante la itinerancia en ciudades como San Francisco, y Londres. A la par de la anterior experiencia se suma el proyecto "Argentina Inter-medios" con una orientación performática cruzada con la experimentación sonora y la imagen en movimiento. Es importante anotar que se acuña el concepto Arte de Sistemas. El trayecto del 69 al 77 se constituye en el fundamento de dicha categoría la cual adquiere notoriedad y difusión internacional y se legitima con la participación de los artistas reunidos en torno a Centro de Arte y Comunicación quienes son reconocidos en la Bienal de San Pablo con el premio Itamaraty con el proyecto -Signos en ecosistemas artificiales- primer reconocimiento a artistas latinoamericanos en dicho evento.

Las décadas de los 70's y 80's propiciaron la expansión de artefactos tecnológicos que para la comunidad de artista locales influyó en la aparición de nuevos lenguajes estéticos. 3 (Ferla, 2005). Las nuevas condiciones que propicia el arte en relación con los nuevos medios y el interés creciente de las multinacionales empeñadas en expandir el comercio e intercambio de las nuevas tecnologías favorecen el surgimiento de eventos, muestras y festivales a nivel local, regional e internacional. De igual manera se crean condiciones para que surjan centros e instituciones que van a propiciar la investigación y la circulación de las nuevas propuestas surgidas desde el arte mediático.

En la década de los 80's aparece la Fundación Antorchas que propició la investigación y producción de obras sustentadas en los nuevos medios. Como fruto de este apoyo surgen los seminarios en Bariloche orientados por Jorge la Ferla en torno a los cuales circulan los discursos contemporáneos de los nuevos medios y de los cuales se beneficia una camada de

3 "Tras la tardía aparición de los equipos portátiles de video en el país, del tipo camcorder, es recién a fines de los años 80 que se puede hablar en Argentina de una producción interesante videográfica con una marcada propuesta expresiva. Y es durante los años 90 que se puede hablar de la producción de trabajos específicamente originales. La ruptura del modelo institucional televisivo era evidente en estos nuevos trabajos que resultaron diferentes a todo el producto estándar del medio siglo anterior. Alguien pensó en un momento las discutibles categorías de arte y creación para toda una serie de obras hechas en video que con el tiempo fueron teniendo su propio espacio a través de muestras y festivales, actualmente en franca desaparición" La Ferla Jorge, El audiovisual en Argentina: uniformización global y creación loca" Ponencia dictada en el Festival Experimenta Colombia, un festival de artes electrónicas colombianas, 2005. 
jóvenes artistas latinoamericanos apoyados por las fundaciones Antorchas, Andes y Vitaes y las becas de la Fundación Rockefeller.

Para los 90's surgieron apuestas desde la academia como es el caso del Centro Cultural Ricardo Rojas, lugar desde el cual se impulsa la exhibición y reflexión en torno al arte surgido de la utilización de los nuevos medios, muestras con el MECVAD, y publicaciones ligadas a los orígenes, desarrollo e historia del videoarte argentino y por supuesto apuestas de las fundaciones privadas de las multinacionales de las telecomunicaciones como Fundación Telefónica, que invirtieron gran capital en la promoción de la cultura y apoyo a todo el espectro actividades relacionadas con el cruce arteciencia y tecnología. 


\subsection{Instituciones que han favorecido el desarrollo y la expansión de las artes}

electrónicas

Las llamadas artes electrónicas tienen en Buenos aires cada vez una mayor aceptación en el escenario del arte, tanto a nivel institucional como de las propuestas desarrolladas por artistas de la ciudad. Para efectos del presente texto se citan a continuación algunas de las instituciones que en Buenos Aires han favorecido el desarrollo y expansión de las artes electrónicas y que presentan relevancia para el contexto aquí tratado.

El Instituto Di Tella fue un proyecto que se centró en la investigación y la creación en el ámbito cultural. Se fundó en el año 1958 y fue clausurado en 1979 por la dictadura de J.C. Onganía. El Centro de Artes Visuales (1963-1969) del Instituto Di Tella fue una propuesta que transformó radicalmente la recepción de los fenómenos artísticos en Argentina. Su director Jorge Romero Brest (1905-1989), fue el director del centro experimental el cual se transformó en sinónimo de vanguardia y contradicción, a la vez que se constituyó en una leyenda emblemática de los años sesenta.

En sus salas de exposición y auditorio tuvo lugar la presencia de las vanguardias artísticas y la manera como desde lo local los artistas de aquel tiempo se relacionaron creativamente con las vanguardias. Del proceso surge la generación del Di Tella de artistas entre los cuales sobresalen figuras como las de Antonio Berni, Líbero Badíi, Gyula Kosice, Liliana Porter, Luis Camnitzer, Lea Lublin, Luis Felipe Noé, Luis Fernando Benedit, Delia Cancela, Jorge de la Vega, Susana Salgado, Ernesto Deira, Rómulo Macció, Antonio Trotta, Oscar Palacio, Julio Le Parc, Rogelio Polesello, Antonio Seguí, Clorindo Testa, Ary Brizzi, Carlos Silva, Carlos Mathus, Roberto Aizenberg, Federico Manuel Peralta Ramos, y Emilio Renart, Luis Alberto Wells, Dalila Puzzovio, David Lamelas, Juan Carlos Distéfano, y Marta Minujín, entre otros.

El Centro de Arte y Comunicación - CayC inicia labores en 1968, fundado por Jorge Glusberg, durante su trayectoria de 25 años participo a nivel internacional en diferentes eventos en los cuales se mostró la expresión de las vanguardias argentinas. "Con las muestras Arte y cibernética y Argentina Inter-medios, en ese mismo año, el Centro se instala como referente bajo la premisa de la búsqueda experimental e interdisciplinaria." (Glusberg, 2012) 
Durante la década de los setentas su labor consistió principalmente en la gestión y proyección de artistas emergentes locales y nacionales. Igualmente, mediante intercambios con otras instituciones y países invitó a Buenos Aires importantes teóricos que desarrollaron workshops y exhibiciones los cuales oxigenaron y nutrieron la escena local del arte con artistas internacionales.

El Centro de Arte y Comunicación fue protagonista del Arte argentino, representó en cierta medida una época de cambios, aunada a la participación ideológica y política en la realidad del país. Se constituyó en un lugar para la experimentación vanguardista, para el debate teórico y la confrontación estética. En su praxis convocó la tecnología, la ciencia, la arquitectura, el diseño y lo más osado del arte contemporáneo.

Para el invierno del 71 El Centro de Arte y Comunicación organiza en el Museo de Arte Moderno de Buenos Aires un evento el cual se convirtió posteriormente en un hito de las artes electrónicas en Argentina, dicho certamen llamado Arte de sistemas congregó más de cien artistas representativos de diversos países, entre los cuales se destacaron los nombres de Arakawa, Christian Boltanski, Christo, Barry Flanagan, Joseph Kosuth, y Nam June Paik.

Desde el Centro surgieron y se proyectaron artistas de figuración nacional e internacional, en particular el llamado grupo de los trece integrado por Leopoldo Maler, Jacques Bedel, Julio Teich, Luis Benedit, Alfredo Portillos, Gregorio Dujovny, Alberto Pellegrino, Carlos Ginzburg, Jorge González Mir, Víctor Grippo, Vicente Marotta, Luis Pazos, Juan Carlos Romero, Clorindo Testa y Horacio Zabala.

"El grupo de los Trece cosecha premios y reconocimientos internacionales. En 1975, se le otorga Medalla de oro en la muestra conmemorativa del $30^{\circ}$ aniversario de las Naciones Unidas, Peace 75, en Slovenj Gradec, Yugoslavia. En 1977 obtiene, por su obra colectiva Signos en ecosistemas artificiales, el Gran Premio Itamaraty en la XIV Bienal de San Pablo.” (Glusberg, 2012)

El Centro no estuvo exento de contradicciones, confrontaciones y polémica pública en el círculo del arte y la cultura local, regional e internacional; se generaron debates promovidos por artistas y críticos de arte. Al principio de los años noventa se realizan las últimas exhibiciones del Centro de Arte y Comunicación, en Tokio y Santiago de Chile, así como el fin de su actividad. 
Desde comienzos de la primera década del dos mil, El Centro Cultural de España en Buenos Aires, CCEBA, favorece propuestas que propician la acción cultural como instrumento para el bienestar social, auspiciando lugares de creación, de reflexión, de participación y fomento de la capacidad participativa de los ciudadanos. Es un centro que impulsa el intercambio cultural entre España y Argentina, además es un espacio generador de propuestas en el área de la cooperación cultural iberoamericana. A través de proyectos que se materializan en conferencias, cine, conciertos, exposiciones, actividades multidisciplinares y espacios de experimentación.

El Centro Cultural de España favorece el componente electrónico a través del MediaLab y tiene como objetivo establecer un lugar de trabajo, producción, investigación y asesoramiento, en el campo del Arte y la Tecnología. Desde esta perspectiva se crean los siguientes escenarios: Laboratorio de Producción, Talleres de Arte y Tecnología, Talleres en red, Cursos de Formatos Digitales y Seminarios Internacionales.

En particular es importante para el presente ensayo referenciar los laboratorios de producción del MediaLab que durante los años 2009-2011 a cargo del ingeniero de sistemas y artista Emiliano Causa y Matías Romero Costas coordinador y asistente, dichos laboratorios favorecieron la presentación de propuestas que exploraron la creación desde el componente electrónico. Los laboratorios se propiciaron por medio de convocatorias con el fin de financiar y apoyar técnicamente y logísticamente proyectos de creación en el área con perfiles de interdisciplinariedad.

La Fundación Telefónica con dos décadas de trayectoria en la ciudad de Buenos Aires favorece procesos de aprendizaje, construcción conocimiento y genera redes y conexiones entre personas, actores sociales e instituciones para contribuir con su desarrollo, a continuación, el siguiente extracto de su página $W e b$ :

"Bajo el lema "Despertando ideas se despierta el futuro" y en el marco de sus ejes de actuación Educación y Nuevas tecnologías, Cultura digital e Innovación y Proyectos sociales y Voluntariado Corporativo, la Fundación fomenta innovación en los procesos educativos, gestiona la red de voluntariado corporativo y facilita la generación y divulgación de conocimiento" (Fundación telefónica, 2012)

De manera particular hace énfasis en el acompañamiento al impacto de la tecnología en las personas y la sociedad, se vincula con niños y jóvenes de diferentes instituciones y 
ONG, la comunidad educativa y referentes de innovación, arte y tecnología. Desde la Fundación y en asocio con el Museo de Arte Moderno de Buenos Aires crean el "Premio MAMBA-Fundación Telefónica" en el año 2002 con el objeto de promover y publicar formas artísticas innovadoras, generando un lugar donde puedan desarrollarse proyectos que amplíen, desde de la tecnología, los linderos de las artes visuales. Además, el premio fomenta el desarrollo de propuestas experimentales y genera un incentivo económico para los artistas galardonados. Se han realizado hasta el momento siete ediciones las cuales han generado una importante participación de artistas y equipos interdisciplinarios.

Las instituciones citadas son solamente algunas de las que han favorecido el desarrollo y auge del arte electrónico en la ciudad de Buenos Aires. Se destaca la importancia y el papel que la institucionalidad del arte y la empresa privada han desempeñado para el posicionamiento de un tipo de arte que en sus comienzos no ha tenido un recibimiento amplio, ni tampoco ha contado con espacios de exhibición que lo favorecieran. En la primera década del siglo XXI, la inversión económica por parte de la empresa privada ha sido fundamental para el financiamiento de proyectos como los aquí estudiados. También ha sido el puente para la circulación y exhibición de los proyectos en escenarios locales, nacionales e internacionales. 


\subsection{Eventos emblemáticos en torno al arte electrónico en Buenos Aires 2002 -}

2012

En la ciudad de Buenos Aires durante lo transcurrido del presente siglo se ha observado una importante producción de eventos en torno al Arte Electrónico, algunos efímeros y otros que permanecen en la escena local y son referentes en el área. A continuación, se hace referencia a tres de ellos los cuales son representativos del desarrollo del Arte Electrónico en la ciudad de Buenos Aires.

\subsubsection{Encuentro FASE}

A continuación, lo descrito com FASE en el sitio Web del evento:

"FASE es el encuentro de arte, ciencia y tecnología de referencia en la Ciudad de Buenos Aires. Es un espacio de pensamiento, exhibición, reflexión, crítica y promoción de las artes visuales. Reúne a instituciones -públicas y privadas, nacionales y extranjeras- para destacar su labor de investigación y desarrollo en nuevos medios como la fotografía, lo audiovisual, el arte electrónico, las investigaciones digitales, la animación, el arte en Internet, los videojuegos, la robótica, el video arte, la biotecnología; tanto en su aspecto high como low tech. Está signado por ejes temáticos que mueven al pensamiento y a las asociaciones transdisciplinarias." (FASE, 2009)

El proyecto FASE se inicia en mayo del 2009 fecha en la cual se da lugar el primer encuentro, desde entonces hasta el año 2102 se han desarrollado cinco versiones, en las cuales se ha dado un viaje transversal por el universo general de los nuevos medios y en particular el arte electrónico. En dichos eventos se puede constatar un devenir de lo local que se expande hacia horizontes regionales e internacionales.

FASE 1 giró en torno al Estado de la cuestión. Se generaron espacios fundamentales de producción a saber:

1. El espacio Homenaje, llamado Pioneros que contó con la participación de Gyula Kosice, Marta Minujin, Margarita Paksa, Víctor Grippo y Luis Benedit. 
2. El espacio Sinapsis, que propició el cruce entre artistas e instituciones y generó un amplio espacio expositivo.

3. El espacio de reflexión en torno al cual se desarrollaron debates, clínicas y workshops.

FASE 2 Del Bicentenario al Tercer Milenio se programó en junio del 2010, y tuvo como ejes temáticos Utopías, Distopías, Atopías.

"Destaca, no las políticas culturales del marketing y el repentismo, si no acciones de mediano y largo plazo que tengan continuidad. Propone el fomento de miradas críticas. Analiza aspectos como la resistencia, el uso de la imaginación y el low tech, junto con las utopías tecnológicas. Muestra ejemplos de cómo la comunicación, la educación, la cultura y el arte son instrumentos de desarrollo individual y social." (FASE, 2010)

Algunos de los artistas bonaerenses que se presentaron fueron. Gyula Kosice, Esteban Álvarez, Juan Doffo, Ricardo Pons, Juan Sorrentino, Hernán Salamanca, de la provincia de Tucumán Alejandro Tolosa, Rolo Juárez, Sebastián Rosso, de Brasil Rachel Rosalen y Rafael Marchetti y los paraguayos Erika Rivas y Javier López.

FASE 3 Zona de Prueba se programó en mayo del 2011, la participación de instituciones locales, regionales e internacionales aumentó, así como la participación de artistas y curadores.

"El eje de esta edición se centra en el arte como proceso con elecciones constantes a través de la prueba y el error. La muestra consiste en intervenciones en sitios específicos, performances y actividades efímeras de carácter tecnológico, programas audiovisuales (cine, video, etc.) videojuego como forma artística, espectáculos y música. Encuentros de reflexión, charlas, debates, mesas redondas y talleres." (FASE, 2011)

FASE 4 Se programó en el 2012 y tuvo como eje conceptual la Post-Ecología.

"Propone la toma de conciencia de la crisis planetaria que ha conducido a situaciones aparentemente irreversibles. Sin embargo, creemos que cierto cambio es posible tanto en lo ecológico como en lo social y político. Esta reflexión surge, en este caso desde el corazón de un campo artístico centrado en la experimentación, con proyectos que están en la periferia del mercado del arte. Desde lo académico, instituciones públicas y privadas, fundaciones, proyectos independientes, colectivos, realizaciones autogestionadas, hasta galerías que apuestan a las búsquedas originales 
y nuevos formatos, todos los proyectos que se muestra creen en el arte como un instrumento de expansión de la conciencia.” (FASE, 2012)

FASE 5 Metáforas de la Supervivencia - Fragilidad de los entornos del Arte y la naturaleza. se programó en el 2012 se centró en las propuestas curatoriales de invitados locales, regionales e internacionales, la participación de artistas fue numerosa y el eje conceptual en torno a la naturaleza, lo ecológico y lo social.

\subsubsection{Centro Cultural de España en Buenos Aires - MediaLab proyectos}

Proyectos MediaLab 2009 fue una puesta en escena de las propuestas desarrolladas en el Laboratorio de Producción del MediaLab del Centro Cultural de España en Buenos Aires. En noviembre del 2008 se abrió convocatoria para la participación en el proceso, se seleccionaron en marzo 2009 cuatro proyectos para ser realizados con el correspondiente apoyo económico con acompañamiento y la respectiva asistencia en el seguimiento del proceso de desarrollo.

"Las obras seleccionadas abordan diferentes temáticas: esculturas creadas a partir de la dinámica de desplazamiento de un grupo de personas, robots musicales capaces de improvisar junto con el público, proyecciones volumétricas, y sistemas de vida artificial con redes neuronales que interpretan la gestualidad facial del público. El objetivo del Laboratorio de Producción es ofrecer apoyo a los artistas vinculados a los nuevos medios (como el arte digital, electrónico o de nuevas tecnologías), brindándoles asesoramiento para desarrollar proyectos de Arte y Tecnología. Como coordinadores de este espacio, es muy importante para nosotros que los trabajos finalicen su proceso en una muestra, cerrando el ciclo entre el artista y el público. Emiliano Causa (coordinador) y Matías Romero Costas (asistente).” (CCEBA, 2009) Los seleccionados participantes y sus proyectos fueron:

- GameLAN. Instalación Robótica Interactiva - Artistas: Juan Pablo Amato. Asistencia Técnica: Diego Alberti.

- 8-10 Vulnerable Social. Instalación Interactiva - Artista: Víctor Emilio Esteve. Asistencia Técnica: Diego Alberti. 
- Ecos de la Impermanencia. Escultura generativa - Artista: Juan Pablo Ferlat. Agentes Autónomos: Luciano Azzigotti, Paulino Estela, Joaquín Ezcurra, Luis Garay, Luciano Lasca, Victoria Sacco, Florencia Vecino.

- Cámara lúcida (derivado del proyecto "Maquetas y Miniaturas"). Instalación interactiva - Artista: Christian Parsons. Asistencia Técnica: Fabricio Costas Alicedo. Proyectos Medialab 2010. Para la segunda versión de la convocatoria el MediaLab giró en torno al desarrollo de proyectos con el uso de nuevas tecnologías en sus propuestas de trabajo.

En la convocatoria se expresa de la siguiente manera las particularidades de la misma:

"Se seleccionarán propuestas de instalaciones, intervenciones, performance multimedia, o cualquier otro formato que aborde problemáticas relacionadas con el desarrollo de nuevas interfaces físicas (interfaces tangibles, realidad aumentada, y sistemas que permitan visualizar -o representar de cualquier otra forma- objetos virtuales en un espacio físico), la conectividad (dispositivos inalámbricos, vinculados a Internet o que permitan tele presencia) o el diseño de nuevos comportamientos en los sistemas (vinculados a la robótica, la vida artificial o la inteligencia artificial)." (CCEBA, 2010)

Los participantes y proyectos seleccionados fueron:

1. Cultus sp. (Dramatización de una interacción difusa) Autores: ScF-129 (Jorge Champredonde, Guido Corallo, Laura Molina)

2. Los Aparatos - Autores: Federico Joselevich y Julia Vallejo.

3. QUÁNTICA - Autor: Paula Rivas

4. siNetesik - Autores: RedPanal (Matías Lennie Bruno) + Lisandro Fernández

Proyectos Medialab 2011. Los proyectos 2011 en el Laboratorio de Producción del MediaLab se reunieron en torno a la fragilidad, la vulnerabilidad y los ecosistemas virtuales.En la convocatoria se expresa de la siguiente manera las particularidades de la misma:

"Para hacer alusión a lo efímero de la existencia, una vanidad contemporánea nos enfrenta a sus artificios mediante objetos de naturaleza electrónica y estética a la vez. Por último, en la panacea de las redes de comunicación actuales, una instalación nos muestra un fantasma que hace caer nuestra última ilusión de seguridad. De esta 
forma, la materialidad electrónica se ha puesto al servicio de los discursos para seguir recreando las formas del decir." (CCEBA, 2012)

La exposición de dichos proyectos se realizó en el año 2012 y Los seleccionados participantes y sus proyectos fueron:

- Efecto mariposa - Autor Patricio González Vivo.

- Generación de conciencia i y ii de la serie @agua_y_aceite - Autores: Álvarez Olmedo Daniel, Diez Diego y Guido Villar.

- El estudio - Autor: Juan Rey.

\subsubsection{Premios MAMBA - Fundación Telefónica - Arte y Nuevas tecnologías}

El evento Arte y Nuevas tecnologías, es único en su género en Argentina y tiene por propósito facilitar la investigación y producción de proyectos artísticos, vinculados a la ciencia y la tecnología. Se lo describe en el sitio $W e b$ de la siguiente manera:

"El Premio MAMBA-Fundación Telefónica nació en el año 2002 con el objetivo de promover y difundir expresiones artísticas innovadoras, generando un espacio donde puedan desarrollarse producciones que amplíen, de la mano de la tecnología, las fronteras de las artes visuales. Además, el premio fomenta el desarrollo de proyectos experimentales y representa un incentivo económico para los artistas galardonados.” (Telefónica, 2011)

Arte y nuevas tecnologías - 2004/2003/2002/ En el año 2005 se publica paralelo a la cuarta edición de los premios MAMBA-Fundación Telefónica el catálogo que agrupa la información referida a las tres versiones anteriores haciendo un recuento de jurados, seleccionados y premiados en cada una de las tres versiones anteriores. Laura Buccellato Directora del MAMBA escribe en dicho catálogo “...este catálogo testimonia las nuevas experiencias visuales, permite apreciar la variedad de las investigaciones estéticas. Registra sus inquietudes; el fenómeno urbano, la identidad, las pequeñas utopías personales, la cotidianeidad, la naturaleza misma y la narrativa ficcional..." (Buccellato, 2005)

Arte y nuevas tecnologías - Cuarta edición -2005. En las categorías de: video arte, multimedia, arte digital, proyecto multidisciplinario experimental LimbØ y gran premio a las nuevas tecnologías; esta edición giró en torno a los nuevos medios. Al respecto se escribió 
en la presentación de la muestra "En lugar de explorar su propio lenguaje, los nuevos medios han preferido frecuentemente proceder a una deconstrucción de los lenguajes visuales y audiovisuales existentes, como las artes plásticas, la fotografía, el cine y la televisión.” (Buccellato, 2005)

Los artistas participantes fueron: Federico Caram, Armando Frezze Virginia Fillol, Graciela Taquini, Iván Ivanoff, José Jiménez, Juan Pintabona, Leonardo Solaas, Leonello Zambom, Martin Bonadeo, Pablo Ziccarello, Paula Gaetano Adi y Sebastián Díaz Morales

Y las obras premiadas fueron: En la categoría video experimental monocanal 2004, Primer premio Gustavo Galuppo, La progresión de las catástrofes, 2004 8'50'”. En la categoría Arte Digital 2004, Primer premio Luis Lindner, Picto bacillus Helveticus, 2004, 6 imágenes digitales, 130 × $50 \mathrm{~cm} \mathrm{c/u}$. En el Premio limb0 a proyecto multidisciplinario experimental 2004, Primer premio Mariela Yeregui, Proxemia, 2005, Instalación, Mención de honor del jurado Proyecto Biopus (Tarcisio Pirota, Matías Romero Costas, Emiliano Causa), Sombras vivas, 2004, Instalación multimedia.

Arte y nuevas tecnologías - Quinta edición -2006. En las categorías de: Video Arte, Multimedia, Arte Digital, Proyecto Multidisciplinario Experimental LimbØ y Gran Premio a las Nuevas Tecnologías.

A continuación, los artistas y grupos premiados en las diferentes categorías: Emiliano Causa, del Grupo Proyecto Biopus, obtuvo el Gran Premio a las Nuevas Tecnologías por su obra Sobre la falta. Es uno de los premios MAMBA -Fundación Telefónica al Arte y Nuevas Tecnologías, que en su quinta edición tuvo un jurado integrado por Laura Bucellato, Fernando Fariña, Rodrigo Alonso, Jorge Haro, David Oubiña, Margarita Paksa y Gustavo Romano. En la categoría video experimental monocanal se llevó los laureles María Antolini, y en arte digital y multimedia experimental ganó Julia Masvernat. El primer premio Proyecto Limbo multidisciplinario experimental fue compartido por Jorge Castro e Iván Marino.

Arte y nuevas tecnologías - Sexta edición - 2008/2009. En el catálogo publicado la curadora invitada Laura Buccellato define el concepto central del evento así:

“... el artista contemporáneo ya no puede eludir esta realidad, es más, se ha sumado a ella y se sirve de esa interacción para nutrir y potenciar su creatividad, a través de las diferentes modalidades y soportes. Esta sexta edición del premio MAMBA-Fundación Telefónica artes y nuevas tecnologías da cuenta de ello. Esta 
forma de operar obliga al espectador a cambiar su óptica y a participar igualmente en el proceso estético, pues el espacio virtual y el real en el que está ubicado están movilizados y modificados por su percepción renovada del espacio interior y exterior." (Buccellato,2009)

Los artistas participantes fueron: Nicolás Bacal, Andrés Denegri, Marcolina Dipierro, Estanislao Florido, Graciela Harper, Mónica Heller, Eduardo Imasaka, Azucena Losana, Hernán Marina, Fabián Nonino, Leo Núñez, Juan Sorrentino, Axel Straschnoy, Carlos Trilnick, Christian Wloch, Leonello Zambon, Antonio Zucherino.

Y las obras premiadas fueron: Gran premio Andrés Denegri, Diálogos (en los bancos de una plaza), Videoinstalación, 2010, Argentina. Segundo premio - categoría proyectos, Leo Núñez, Espacio cambiario, instalación interactiva, 2010, argentina. Tercer premio - categoría proyectos, Nicolás Bacal, 4.440 veces vos 2010, Argentina. Primer premio - categoría obras realizadas, Carlos Trilnick, Dead underground 5' 30" 009, Argentina. Segundo premio categoría obras realizadas, Hernán Marina, Le partenaire, 2007, 30' 15'”, Tercer premio categoría obras realizadas, Azucena Losana, Loco (paparazzi iii) 1' 45" 2008, Argentina.

Arte y nuevas tecnologías - Séptima edición - 2011/2012. Laura Buccellato, Directora del Museo de Arte Moderno de Buenos Aires y curadora invitada de la muestra, en el catálogo del evento comentó:

"Esta séptima edición del premio da cuenta — como lo hizo a través de las distintas ediciones - de la incidencia de los nuevos medios en el panorama artístico local, donde las tecnologías se suceden unas a otras, aceleran el tiempo y ocupan espacios impensables. La creación artística se inserta transgrediendo las formas de la simple información, con la intangibilidad de sus pensamientos y el carácter de obra inmaterial que adquieren estos nuevos soportes, cada vez más interdisciplinarios, que invaden la cultura planetaria" (Buccellato,2011)

La presente edición contó con la participación de un jurado integrado por artistas y críticos de arte nacionales e internacionales, como Jim Campbell (artista, USA), Rejane Cantoni (artista, Brasil), Jorge Haro (artista, Argentina) y Mariano Sardón (artista, Argentina) y María Victoria Simón (en representación de Laura Buccellato, Directora del Museo de Arte Moderno de Buenos Aires).

Y las obras premiadas fueron: 
"Insight”, de Sebastián Díaz Morales es la obra ganadora del Gran Premio en la categoría Proyectos incentivo a la producción artística. La instalación "THUMOS (CorazónImpulso)", de Jorge Caterbetti, obtuvo el Primer Premio; mientras que el segundo se le otorgó a Christian Wloch por su obra Antenópolis y el tercero a Marcello Mercado por Paisajes con vacas (no hay nada más puro que la sombra de una vaca). En la categoría Obra Realizada, el jurado otorgó el Primer Premio a Yamil Burguener por su trabajo Spill Over Ber. Constelaciones de Ananké Asseff obtuvo el Segundo Premio; y La simultaneidad de nuestra percepción de la luz de Nicolás Bacal, el tercero.

Como se puede observar en la reseña de instituciones y eventos citados, en la ciudad de Buenos Aires se ha generado un importante espacio de reflexión, investigación, creación, circulación, publicación e intercambio en torno al arte electrónico y los nuevos medios. Proceso que paulatinamente articuló lo local, lo regional y lo global, favoreciendo el surgimiento de una cultura de los nuevos medios, de un nuevo público y de una generación de artistas que se posiciona en los diferentes ámbitos, a la vez que se construye un relato que tipifica la manera como desde lo local se proyecta la reflexión y participación a escenarios internacionales en torno al arte electrónico. Ha sido en escenarios como los descritos, en los cuales el arte electrónico producido y exhibido en sus diversas manifestaciones en la ciudad de Buenos Aires ha generado una apuesta que desde la experiencia local ha replanteado el rol del público. 


\section{Capítulo 3 Arte electrónico}

El siglo XX fue el escenario en el cual se desarrollaron variadas y múltiples manera de expresión artística, las cuales desbordaron los límites de los procesos iniciados por las vanguardias. Dichos desarrollos artísticos tuvieron como soporte a las nuevas tecnologías de la información y los denominados nuevos medios.

Arte electrónico hace referencia según Claudia Giannetti a la "Corriente de la creación artística contemporánea que utiliza las tecnologías electrónicas y/o digitales (audiovisuales, computarizadas, telemáticas)." (Giannetti C. , 2002, pág. 191) como se citó al inicio del documento, el artista Mariano Sardón al respecto dijo: “Artes electrónicas son artes que incorporan tanto formal, material, como paradigmáticamente la electrónica al proceso artístico. Detrás de toda tecnología hay una mirada y construcción del mundo, y con ella operamos los artistas." (Sardón, 2005) Con base en las definiciones anteriores Arte electrónico es la denominación que se adapta a diversas tipologías expresivas-creativas artísticas, las cuales emplean la tecnología electrónica como soporte tanto para la materialización como para el establecimiento de la relación entre el público y la obra.

La intersección entre arte, ciencia y tecnología en el siglo XX dibujó un nuevo horizonte creativo en el que los aspectos formales y conceptuales del arte se trasformaron. El termino New Media Art, se ha utilizado desde el idioma inglés para referirse a este escenario. Término impreciso que dio origen a diversas discusiones acerca de su significado y límites. Desde este lugar la voz inglesa New Media Art se tradujo como Arte de los nuevos medios simultáneamente junto a otros términos como Media art, Arte electrónico y otros. Sin embargo, el término aquí utilizado es Arte electrónico, el cual es cercano al contexto de la presente investigación. A continuación, otros acercamientos a la tipificación del término desde la referencia New Media Art:

"Entendemos el media art no como una corriente autónoma, sino como parte integrante del contexto mismo de la creación artística contemporánea. El hecho de emplear el término media es un recurso para diferenciarlo (y no apartarlo) de las manifestaciones artísticas que utilizan otras herramientas que no las basadas en las tecnologías electrónicas y/o digitales. A pesar de optar en este ensayo por emplear en general el término media art, reconocemos que otros términos, como arte electrónico, 
también logran transmitir este carácter más amplio y global de todas las manifestaciones artísticas que utilizan las llamadas nuevas tecnologías (audiovisuales, computarizadas, telemáticas).” (Giannetti C. , 2002, pág. 12)

“...describe un proceso en el que las tecnologías existentes y las nuevas y emergentes son usadas por los artistas para crear obras que exploran modos de expresión artística, desde el arte conceptual al virtual, a través de la performance o la instalación y que integran los nuevos medios tanto en cómo se concibe y crea la obra (o un componente de la obra) como en el modo en que se presenta al público.” (VVAA, 2006) “...el fenómeno artístico de armonización entre los medios de comunicación y las prácticas artísticas. Un reto expresivo derivado de una actitud experimental en la concepción, las metodologías de trabajo, los métodos de producción y el uso de tecnologías de comunicación audiovisual y/o multimedia para la creación artística." (Gómez, 2013)

Es innegable, que los nuevos medios propuestos por Lev Mano Vich4 y la electrónica afectaron a la obra de arte de diversas formas. Los componentes electrónicos y sus lógicas de funcionamiento, entraron a formar parte de los materiales del artista. Se suscitó la oportunidad para nuevas formulaciones expresivas, objetuales y no-objetuales que se materializaron en los nuevos soportes electrónicos y que a su vez cuestionaron el papel del espectador en su relación con la obra de arte.

La gran diversidad de soportes electrónicos, permitió el uso y la posterior integración de medios. El carácter multimedial del arte electrónico permitió el sincretismo expresivo, así como el uso interrelacionado de soportes cada vez más dispares. Espacio y tiempo, dos variables permanentes de la ecuación del arte del siglo XX, se convirtieron en elementos fundamentales del proceso creativo, es así, como espacio y tiempo se relativizan y bifurcan en diversas direcciones expresivas que dieron lugar a nuevas relaciones en los procesos de circulación, exhibición y recepción de la obra de arte.

El fenómeno interactivo desencadenó nuevas actuaciones para el público, nociones como las de autoría y completitud de la obra se resolvieron de nuevas maneras. La búsqueda

4 “...aquellos que implican al ordenador (las tecnologías informáticas) en cualquiera de las fases de la comunicación, sea la captación, la manipulación, el almacenamiento o la distribución, y que afectan a todo tipo de medios, ya sean textos, imágenes fijas o en movimiento, sonido o construcciones espaciales." (Manovich, 2005) 
de interacción y participación del público se opuso al rol tradicional del público. Se generó una traslación de sentido de la obra hacia el espectador, ya Umberto Eco lo propuso a través del concepto de obra abierta, en la medida que el espectador a partir de sus aportaciones, participación y actuación incide en la terminación o cierre de la obra misma. (Eco, Obra abierta, 1990)

El proceso de difusión del arte electrónico implicó superar las barreras implícitas de los limitados ámbitos de mercado artístico tradicional. El espacio de la galería y del museo fueron insuficientes para la gran diversidad de manifestaciones del Arte Electrónico. En la era de las comunicaciones y de la sociedad de la información, el acceso aleatorio a la Internet permitió el surgimiento de nuevas formas de creación y expresión artística.

La interactividad fue sin duda alguna un hilo conductor, un denominador común en el desarrollo del Arte Electrónico. La interactividad tuvo en las vanguardias precursores como Joan Miró y Alexander Calder presente en sus móviles. László Moholy-Nagy con sus máquinas que utilizaban ruedas, engranajes y muelles para ser accionadas con palancas, y los artefactos creados por Marcel Duchamp. La poesía Dadá propuso la construcción aleatoria de textos a partir de la intervención del azar. Man Ray elaboró láminas de cristal giratorio, que proponían a los espectadores interactuar con el artefacto y manipularlo desde cierta distancia.

El desarrollo de los medios de comunicación y su posterior auge generó y modeló nuevas audiencias, nuevos públicos, nuevas maneras de consumo y de relación con la información. Estos desarrollos electrónicos dieron lugar a la creación de formas expresivas que utilizaron sensores, sistemas de grabación, reproducción de imagen y audio. El grupo ZERO surgió, así como la publicación Leonardo de Frank Manila que giró en torno a la relación ciencia, arte tecnología.

Video, televisión y el registro magnetofónico fueron tecnologías que desde sus incipientes orígenes ingresaron con fuerza en el escenario de creación que los nuevos medios generaron. La aparición del video arte devino con figuras como las de Bruce Nauman, y el coreano Nam Jume Paik, artistas que hicieron de la utilización del soporte electrónico la materia prima para sus creaciones y a partir de la cual desarrollaron un lenguaje distante de las formas televisivas convencionales. N.J. Paik decía que: 
“...de la misma manera que el collage ha sustituido el óleo, el tubo de rayos catódicos sustituirá el lienzo.", "Estamos creando realmente un nuevo tipo de lienzo, unos nuevos pinceles. Yo soy, de alguna manera, un ingeniero investigador como lo es un investigador científico. Crear una obra es, para mí, lo mismo que investigar los medios." (Pérez, 1991, pág. 33)

Y dichos procesos de investigación propiciaron otras formas de uso de la imagen electrónica por medio de instalaciones y video esculturas en las que los monitores fueron los contenedores de otros materiales y de nuevos usos. La video creación se expandió, exploró de nuevo las coordenadas espacio y tiempo, dio nuevos sentidos a la corporeidad y a la presencialidad, en resumen, el uso del video sirvió como un mecanismo de investigación de la realidad más allá de lo lineal y lo aparente; artistas como Bill Viola y Gary Hill se distinguieron en esta dirección.

La interacción digital supero las dificultades de los distintos procesos utilizados. La capacidad multimedia de las tecnologías informáticas sustituyó la mayoría de los procedimientos anteriores existentes. De otro lado la cultura digital se expandió por la $\mathrm{Web}$ 1.0 y 2.0 y las distintas redes ligadas a Internet. En las dos décadas finales del siglo XX el auge de la tecnología digital y su utilización por parte de diversidad de artistas en todo el mundo se incrementó, propiciando un desplazamiento de la investigación creativa del arte electrónico del video hacia otras formas de expresión que involucraron otros dispositivos y artefactos. El auge de una nueva cultura digital se auspició por parte de intelectuales, artista y escritores. William Gibson en el año 1984 publicó su famosa novela Neuromancer en la que introdujo el término "ciberespacio" para referirse al nuevo universo de datos y redes que los hombres vivenciarían como un útero orgánico de información. (Gibson, 1984)

Los ordenadores se integraron a la vida cotidiana. Los individuos se convirtieron en usuarios de software y lo emplearon para manipular imágenes demostrando que la expresión artística no era algo exclusivo de los artistas formados en la académica $^{5}$. La

\footnotetext{
5 "El ordenador, el innovador componente de la técnica expresiva, habría de servir para una amplia variedad de actividades creativas. Muchas de ellas no eran sino otras formas de crear imágenes bidimensionales con una nueva herramienta que facilitaba el collage. Pero en muchos otros casos dio pie a una nueva forma de expresión artística cuyo soporte serían las nuevas redes de interacción que terminarían por conformar a partir de 1989 Internet" Castell, Manuel. La galaxia Internet. Reflexiones sobre Internet, empresa y sociedad. Plaza y Janés. Barcelona, 2001
} 
multisensorialidad se hizo presente con la aparición y masificación de los computadores. La llamada realidad virtual expandió los límites de la visión y del tacto. La simulación y creación de entornos ficticios posibilitó el manipularlos y alterarlos. Un vasto campo abierto se expandió en el horizonte del ciberespacio, las manifestaciones tradicionales fueron sustituidas y las barreras entre público y creador se desdibujaron.

La interactividad global es un término que designa la unión de distintos sistemas informáticos conectados en red. Se entiende entonces a la comunicación como un campo de acción con valor estético. Roy Ascott fue uno de los artistas de avanzada en los campos de la cibernética, la telemática, y la interactividad. R. Ascott fue uno de los precursores de algunos de los proyectos pioneros más importantes y paradigmáticos en la red.

Tanto el museo objetual y la galería de arte como contenedores en este nuevo contexto dieron paso a nuevas maneras de exhibir virtualmente en la red. Como señala Cynthia Freeland respecto a Internet “...ha abierto las fuerzas productivas de la sociedad, al menos en las naciones avanzadas, para que casi todos puedan participar. Uno no tiene que ser un artista con título ni una galería para crear un sitio que se pueda transmitir por todo el mundo y obtener inmediato reconocimiento.” (Freeland, 2003, pág. 210)

Nuevas construcciones del mundo, nuevas maneras de interactuar entre obra y público, diversidad de formas de circulación, creación de nuevos espacios y temporalidades, son solo manifestaciones que han devenido de la incorporación del sustrato electrónico en los procesos de creación y producción de la obra de arte. El Arte electrónico ganó un lugar en el universo del arte en general. Las fronteras entre arte, ciencia y tecnología se desvanecen en el escenario del arte electrónico, nociones como la de autor, público y las diversas formas de participación de los receptores son reinventadas a partir de las creaciones electrónicas. La realidad del público y su dependencia del mundo virtual o simulado planteadas desde los sustratos del Arte Electrónico, ofrecen puntos de reflexión para la estética digital, los conceptos clásicos de verdad, originalidad, trascendencia, autonomía entre otros han sido trastocados. Para finalizar este apartado referido al Arte Electrónico, Peter Weibel dijo:

"Los medios electrónicos, en su conjunto, representan el intento del ser humano de simular, en el interior del universo, una evasión hacia fuera del universo. Los mundos mediáticos son mundos artificiales, y modelos de mundos creados por el 
ser humano, que dejan patente que este solo es un observador interno en el mundo, pero que en los mundos mediáticos puede ser un observador interno y externo simultáneamente.” (Giannetti C. , 2002, pág. 176) 


\subsection{Interactividad}

"La obra de arte electrónica interactiva exhorta el paso desde la teoría estética clásica, centrada en el objeto de arte, hacia una nueva teoría que tiene como punto de referencia principal el observador, el público, el usuario.” (Giannetti C. , 1997, pág. 77)

"Los nuevos medios son interactivos. A diferencia de los viejos medios, donde el orden de presentación está fijado, ahora el usuario puede interactuar con un objeto mediático. En ese proceso de interacción, puede elegir qué elementos se muestran o que rutas seguir generando así una obra única. En este sentido, el usuario se vuelve autor de la obra." (Manovich, 2005, pág. 103)

Hablar de medios electrónicos, telemáticos o de arte electrónico implica señalar la característica de la interactividad. Los dos autores citados anteriormente señalan la explicites de la interactividad en los nuevos medios o en el arte electrónico. A nivel básico y generalizado, el hecho de establecer un modo de conexión entre el medio y el usuario o entre la obra y el público se considera una interacción.

Retomando el concepto de interactor como participante activo en el sistema y dependiendo del grado de inmersión del mismo se encuentran dos gradaciones de interactividad a saber: interacción débil o simulación débil como es el caso de las imágenes ficticias o estructuras que permiten una experiencia real limitada, o el caso de los juegos en los cuales se mantiene la conciencia de una no veracidad y las simulaciones fuertes o ficciones cuasi reales, en las cuales el interactor no puede establecer diferencias entre ambas realidades, además dicha experiencia puede ser compartida con otros bien sea en espacios virtuales o reales.

La participación del espectador se convierte en un componente tanto esencial como complementario en los sistemas interactivos. ${ }^{6}$ De dicha participación y de la relación que se

\footnotetext{
${ }^{6}$ La interactividad del Media Art consiste, así, en los tres elementos de la imagen digital: la virtualidad (del almacenamiento de la información), la variabilidad (del contenido pictórico), y la viabilidad (de la función pictórica). De manera que la imagen se transforma en un sistema dinámico, cuyo comportamiento imita la vida real. Si un organismo vivo es un sistema que reacciona independientemente de la existencia individual, entonces el sistema de la imagen dinámica, que consiste en variables multisensoriales y reacciona ante el input, también es un organismo vivo." Peter Weibel (Peter Weibel, Postontologische Kunst, 1994, in: Romana Schuler, Bildwelten, p. 242.
} 
produce en su actuación, así como las relaciones que se establecen con el entorno y el contexto del sistema se suceden diferentes tipologías de los sistemas interactivos.

La conceptualización por parte de teóricos de las ciencias informáticas, ingenieros y artistas con respecto a la interactividad y a los sistemas de comunicación humano-máquina son bastantes prolíficas, contradictorias y polémicas; a causa de la variedad de conceptos referidos a los procesos interactivos, a los sistemas interactivos y a la misma interactividad, así como a su delimitación, se hace necesario hablar de las ideas de algunos autores que se distancian o se acercan de las categorías de análisis utilizadas con respecto al tema, la elección de algunas es arbitraria y tan solo pertinente para efectos del presente texto.

Umberto Eco ya planteaba en su texto Obra Abierta la participación implícita de un espectador no desde lo digital sino desde la contemplación sin una participación física directa, como un asunto meramente mental,

"En el acto de reacción a la trama de los estímulos y de comprensión de su relación, cada usuario tiene una concreta situación existencial, una sensibilidad particularmente condicionada, determinada por cultura, gustos, propensiones, prejuicios personales, de cómo la compresión de la forma originaria se lleva a cabo según determinada perspectiva individual. (Eco, Obra abierta, 1990, pág. 33)

También es cierto que Umberto Eco plantea una relación de segundo orden diferente a la anterior en la cual el espectador establece una relación con la obra participante, desde la manualidad y producción de la obra.

Robert Jauss y Wolfgang Isser en sus planteamientos referidos a la estética de la recepción desde la relación texto-lector reivindican el papel activo del receptor y su intervención en el texto. En ese sentido la estética de la recepción plantea que el texto se transforma en obra solo mediante la participación activa del lector. (Jauss, 1992)

La experiencia activa del público en las obras no es propia de lo digital o de las computadoras. En el pasado, existieron procesos artísticos que se sirvieron de otros mecanismos para hacer participar al público. Dicha intencionalidad de interactividad se dio en obras de Max Ernst, Marcel Duchamp, incluso encontramos el caso de artistas que emplearon la tecnología como László Moholy-Nagy.

Artistas como Roy Ascott, Davis Rokeby o Myron Krueger son optimistas con respecto al componente tecnológico, al considerar posible un intercambio y dialogo extenso 
así como minucioso entre el sujeto que interactúa con la obra y el sistema computarizado; Lynn Hershman al igual que Richard von der Malsburg plantean que los condicionantes socioculturales del observador establecen fronteras en la capacidad del sistema de generar en el público vivencias nuevas, así como la posibilidad de que la maquina sea convierta en interlocutor; en el caso de artistas como Paul Sermon o Agnes Hegedüs plantean a la maquina como intermediario tecnológico que propicia el dialogo entre dos o más interactores.

Pau Waelder define el Arte Interactivo desde este punto de vista:

"Las obras de Arte Interactivo establecen una relación dialógica entre espectador y obra de manera que son las acciones del primero las que dan forma a esta última, hasta el punto en que la obra no "existe" si no hay un espectador interactuando con ella. Típicamente tienen forma de instalación, en la que el visitante genera un input por medio de su presencia (detectada por sensores), o bien accionando dispositivos dispuestos a tal efecto. La obra crea unas condiciones básicas para su funcionamiento, pero es la acción del espectador la que proporcionará un resultado único en cada ocasión.” (Waelder, 2008, pág. 12)

El científico Roger F. Malina profesor de arte y tecnología en la Universidad de Texas hace una clasificación de los medios interactivos en su libro El comienzo de una nueva forma de Arte vista desde los dispositivos técnicos así:

“1) la posibilidad de llevar a cabo una interacción que cambie el estatus del ordenador;2) la viabilidad del ordenador de integrar posibilidades de aprendizaje, de forma que el estatus interno del ordenador pueda cambiarse cuando se produce la interacción; 3) La posibilidad de conectar varios computadores físicamente remotos a través de redes de telecomunicación; 4) La facultad de asimilar y procesar de diversas maneras señales de forma sinestésica; 5)La capacidad de almacenar gran cantidad de información que sean accesible de forma sencilla.” (Malina, 1999, pág. 155)

A continuación, la conclusión que el Artista Jim Cambell escribió en el texto de la conferencia que presentó en el MoMA de new York en 1999 y que se reprodujo en el catálogo Interactivos del año 2006 con ocasión del programa Interactivos 2 del Espacio de la Fundación Telefónica de Buenos Aires:

"La diferencia entre un juego interactivo y una obra de teatro interactivo no descansa solo en su tema. También lo hacen en el programa y la interfaz, que son 
partes de la expresión de una obra. Los artistas que trabajan en este campo continuaran teniendo problemas con los modelos y las direcciones de la industria multimedia. El arte interactivo todavía no llego a ese punto. Probablemente, el único diálogo significativo que se produce mientras se interactúa con una obra se da en los espectadores mismos. Respuestas de la obra, que son reflexiones alteradas de las de los espectadores. Las limitaciones con las que nos encontramos hoy ya no son tecnológicas. A medida que entendamos mejor la comunicación, será viable expresar no solo un pensamiento, Sino un fragmento de una forma de pensar y crecer." (Cambell, 2006, pág. 19)

En la misma publicación citada del evento Interactivos 2 - 2006, el Artista Emiliano Causa integrante del grupo Biopus acerca de la interactividad dice:

"...consideramos como "arte interactivo" aquel que permite integrar, de alguna forma, el discurso o acción del público en el discurso de la obra, al punto de que dicho discurso esté directamente determinado por la acción de tal público $\mathrm{Y}$ dependa de este para su existencia”. (Causa, 2006, pág. 22)

Las formas de vivenciar el arte han evolucionado, la interactividad a partir del arte electrónico propicia maneras diferentes para el público. Las propuestas del arte electrónico que recurren a la interactividad, seguramente por su base digital, enfrentaran problemas con al pasar el tiempo, tales como el cambio de sistemas operativos y la obsolescencia propia, dado que cambian los medios, etc.; a pesar de ello esto obliga al artista y a sus propuestas a recrearse permanentemente y esto posibilita la innovación y el desarrollo de múltiples posibilidades. Ante el paso del tiempo, el arte debe adaptarse para sobrevivir a la situación actual, donde las creaciones artísticas se tecnifican y lo tecnológico se humaniza. Mantener el sentido tradicional se dificulta, y la flexibilidad del mismo, permitirá su sobrevivencia ante el horizonte de desplazamiento de las fronteras disciplinarias. 


\subsection{Instalación}

El concepto de instalación se presenta como un espacio teórico abierto e inestable, el cual enmarca de manera flexible un conjunto heterogéneo de procesos, prácticas y experiencias artísticas de difícil catalogación en el ámbito de las categorías tradicionales. La instalación no obedece a caracterizaciones morfológicas especificas o determinadas, no se emparenta, relaciona o asocia a procesos técnicos singulares, sino que hace referencia a maneras determinadas de proponer arte. El sustrato de la instalación cubre gran diversidad de producciones diversas. Se podría hacer un extendido de las diversas manifestaciones y corpus que ha comprendido tales como temporalidad, espacialidad, tridimensionalidad, transitabilidad, privacidad, publicidad entre muchos otros. La instalación como constructo híbrido articula diversidad de dispositivos espacio-temporales lo que confirma su carácter abierto, mutante y escurridizo lo que la hace susceptible de múltiples interpretaciones.

La construcción del corpus teórico en torno a la instalación se ha definido al interior de la praxis en el campo de la producción y la recepción crítica. El arte minimalista de la década de 1960 introdujo el término. Dicha década convulsionó la práctica artística en todos sus niveles. El lugar del observador en la relación arte - público fue tema central de las búsquedas de los artistas en dichos años. Se experimentó en diversas direcciones buscando trastocar el papel del espectador separado y extático hacia la generación de comportamientos participativos activos por parte del público. Se producen entonces alteraciones radicales en las diversas maneras de hacer arte, de consumirlo y de circularlo. Los criterios y postulados modernistas son puestos en crisis a través de gran diversidad de estrategias, que procuran una fusión entre el mundo del arte y el de la vida. La construcción de nuevas temporalidades y espacialidades en las cuales lo concreto y lo experimental se interconectan de nuevas maneras produce cruces e hibridaciones que nuevamente confirman la imposibilidad de cualquier categorización precisa.

El teórico Donald Judd, en 1965 escribió al respecto en la revista Art Yearbook un artículo titulado "Specific objects” en el que manifiesta que: “...las mejores obras de los últimos años, no son pintura ni escultura. Por lo general, tienen un vínculo, cercano o lejano, con una u otra. Las obras son diferentes, y mucho de su contenido, que no es pintura ni escultura, es asimismo diferente... Las nuevas obras en tres dimensiones no forman un 
movimiento, una escuela o un estilo.” (Judd, 1965, pág. 8) Se puede observar el desconcierto que mucha de la novedosa producción artística de los años 1960 causó en el escenario del arte.

En los sesenta se utilizó diversos términos para referirse a muchas obras que no eran categorizables dentro de las esferas tradicionales de clasificación o tipificación. Se habló de Ensamble y Environment, posteriormente se fue extendiendo el término instalación el cual convivió con otros como Ambientes, Lugares específicos, Objetos específicos e incluso Esculturas en términos expandidos.

La suma de construcciones teóricas en torno al concepto instalación se fue perfilando como un objeto de estudio específico a nivel académico y teórico. A continuación, algunas aproximaciones en torno a la noción instalación:

“... borra las líneas de separación de las diferentes formas de hacer arte, entre pintura, escultura, arquitectura, fotografía, cine y vídeo, ready- made, teatro y arte vivo, música, etc. (...) confunde el rol del artista con el del espectador. Funde arte y vida (...) No es solo otra forma de hacer arte. Instalación es en lo que se ha convertido todo el arte (...) por lo tanto "instalación” es una tautología." (Watkins, 1997, pág. 24)

"En el campo del arte, método de generación de nuevas formas de expresión como procesos que buscan los siguientes objetivos: la práctica interdisciplinar e híbrida y congénita; la ruptura con la forma cerrada del objeto; el énfasis en las ideas de site-specific y de intervención; la investigación de la relación entre contexto, tiempo, y partes componentes de la obra; la multiplicidad e interrelación de elementos materiales; la preocupación por el papel que desempeña el receptor; el protagonismo de la noción de proceso; la comprensión de la obra como espacio social, público, y la potenciación de la poli sensorialidad de las obras.” (Giannetti C. , 2002, pág. 194)

“...un tipo de manifestación artística tridimensional, interesada principalmente en la manipulación y activación del espacio en el proceso de relacionar elementos, tradicionalmente separados, en un todo articulado, y concentrado en la idea de interacción entre obra y experiencia física, subjetiva y temporal del espectador." (Argíles, 2009, pág. 19) 
La diversidad de ópticas posibilita identificar la marcada tendencia a lo difuso, complejo, e interdisciplinar. Los roles se trastocan, los limites se expanden, lo disciplinar se desborda y la ambición totalizadora de tiempo y espacio se entrecruzan.

El lugar del público participante del espacio instalativo lo lleva a adentrarse físicamente en dicho espacio y por consiguiente a experimentarlo con su cuerpo como totalidad sensorial desde una realidad externa - exo - y una realidad interna - endo - la de la obra. Las relaciones que se establecen entonces son de diverso orden y de diferente nivel. Se propone entonces indagar en los diversos niveles de interacción y participación con referencia a este tipo de propuestas teniendo como supuesto el hecho que el espectador tradicional se disuelve, se desdibuja y se trastoca de manera tal, que la presencia del público inmerso en las instalaciones y sus atmosferas lo hace habitante de las mismas, las completa, les da sentido y las recrea en la medida que su tránsito por ellas está determinado no por el trazo diseñado por el artista sino por la libertad participativa que la misma instalación ofrece. 


\subsection{Instalación Interactiva}

La instalación interactiva a que se hace referencia en la presente investigación tiene como característica lo que el artista Mariano Sardón dice “...las obras interactivas pensadas como la construcción de interfaces relacionales, en la que el artista establece vínculos entre parámetros a través de la computadora utilizando la posibilidad que ofrece la tecnología digital”. (Sardón, 2009) En cierta medida la interacción que se propone en este tipo de instalaciones es de corte dinámico, en la que las variables espacio-temporales se circunscriben a criterios de programación, criterios de interfaz, criterios de circulación espacial y de actuación. Las instalaciones de este tipo proponen diversos lugares para el artista, el público y el objeto de la obra. El componente relacional en la instalación interactiva, se establece desde la programación por medio de la estructuración de códigos, la interconexión a través de interfaces y el uso de dispositivos, para censar variables como movimiento, color, luz, sonido entre otras.

En las instalaciones interactivas, el cuerpo como superficie, el espacio como contenedor, el ambiente sonoro, la atmosfera lumínica, los dispositivos utilizados para establecer el contacto, la comunicación, las imágenes, y la temporalidad son un entramado híbrido que posibilita la experiencia estética del público por medio de relaciones y conexiones cruzadas de cierta complejidad.

El diseño de una instalación interactiva implica la formulación de las maneras de relación entre público, entorno y datos o información digital que se manipula. Las múltiples relaciones que se establecen, parten de un estado potencial que no se afecta hasta que alguien lo activa o manipula de manera directa o indirecta. La latencia implícita en la instalación interactiva germina a partir de un agente externo que la interfiere, razón a partir de la cual se generan diversos niveles de intercambio entre público y obra. Las interrelaciones que se propician no necesariamente se gestan a partir de personas, cualquier otra fuente diferente de datos externa o interna puede desencadenar respuestas.

Las instalaciones contemporáneas mediadas por el uso de las tecnologías electrónicas y digitales, bien sea audiovisuales, telemáticas o computarizadas, que se basan en interfaces técnicas y que permiten la relación dialógica entre la obra, el público y el sistema se han denominado instalaciones interactivas. Dichas relaciones se han dado de diversas maneras 
utilizando formas interactivas bien sea telemáticas, de inteligencia artificial, de red, y realidad virtual. Las instalaciones interactivas son entonces también sistemas de estructura abierta, pluridimensional y compleja.

Las instalaciones interactivas se preguntan por la inclusión del público y la construcción de sentido a partir de dicha inclusión. Las variaciones posibles de inclusión son innumerables y los niveles de los mismos van desde una participación externa hasta una interna inmersoa en una realidad ajena a él y propia del ambiente construido. Procesos reactivos, generativos, de inmersión y de simulación son caminos abiertos que dibujan roles diversos para el público. Otra característica de las instalaciones interactivas es el desplazamiento de la noción de autor debido a la participación del público en los procesos de activación y completitud de la obra.

El objeto artístico de la Instalación interactiva requiere de la participación de forma directa o indirecta desde afuera o desde adentro, con el fin de propiciar desarrollos espaciales y temporales a través de transformaciones sucesivas que propician un constante re significación tanto del público como de la obra y el productor. Los dispositivos tecnológicos utilizados son sensibles a factores variables como posición, movimiento y aceleración en el espacio, peso, gravedad, levedad e ingravidez en términos de la variable física masa; igualmente variables de orden ambiental como atmosfera, temperatura, presión y altitud, o de datos provenientes de intranet o Internet. Los puentes de relación que se pueden establecer con las variables citadas ( $\mathrm{y}$ otras) son posibles a partir de conexiones que procesan la información por medio de algoritmos, códigos, programas y la transforman en diversas formas de salida o materialización.

La conexión de dispositivos tecnológicos a computadoras permite establecer puentes de relación entre variables físicas a través de la tecnología digital. La información obtenida del mundo exterior a través de sensores, puede ser almacenada y transformada de muchas maneras por medio de algoritmos y programas, produciendo diferentes formas de salida o materialización del proceso de manipulación de la información.

Similar a los protocolos comunicacionales que determinan y definen un modo de procesar y hacer las cosas, en el caso de las instalaciones interactivas el artista establece de una manera determinada el vínculo entre software y hardware con el propósito de generar vínculos entre el objeto artístico, el mundo y el público. Las sucesivas transformaciones que 
sufre la información que alimenta la instalación, constituye un dispositivo sistema-obra que porta su propio dinamismo de manera tal que la atención se centraliza en las vías de materialización de la información.

La instalación interactiva que tiene por sustento el componente electrónico y que favorece nuevos roles tano para el público como para el productor, expandió sus bordes y generó un entramado de relaciones que la ubican dentro del concepto arte - sistema conformado por el público como agente activo, el contexto, la formalización y materialización de la información. El artista se apropia de la tecnología y crea hibridaciones que usan todo tipo de artefactos, les asigna fines diferentes para producir tensiones y propiciar formas de comunicación mediante diversidad de interfaces. El productor estructura protocolos, los materializa en procesos, para luego definir ciertas estéticas que evolucionan en tiempos indeterminados y son signadas por la participación del público. Concibiendo a la instalación interactiva como un sistema dinámico y orgánico, se posibilita la comprensión de la acción del público como una energía que alimenta dicho sistema a la par que las reglas establecidas y que se han configurado en forma de algoritmos. El artista esboza las condiciones iniciales de la instalación y deja en manos de la participación del agente externo, la evolución siempre impredecible de las variables formales que puedan llegar a suceder una vez el control se comparte con el público.

La instalación interactiva se configura entonces como un espacio-tiempo en el cual se materializan estéticas de lo mutante, impredecible y en permanente cambio y reconfiguración a partir de los nexos interactivos entre espectador y sistema o entre sistema y otros sistemas. 


\subsection{Instalación robótica}

Hacer extensivo los conceptos planteados en los dos apartados anteriores al ámbito de la robótica implicaría al menos considerar aquel que hace referencia al uso de las tecnologías electrónicas y digitales que utilizan sensores y permiten el procesamiento de la información y la conversión de datos en comportamientos tanto internos como externos de la diada hombre-máquina, maquina-maquina propuestos ya en el pasado en los postulados base de la cibernética. Se hace entonces necesario revisar de las Instalaciones Interactivas aquello que se refiere a la relación dialógica entre la obra, el público y el sistema y en particular al rol del participante con el espacio robótico, así como la relación que desde la robótica se establece entre máquina y máquina.

El lugar de la robótica en el arte contemporáneo se equipara al de otras manifestaciones como la multimedia, el video, las instalaciones interactivas, y la performance circunscrita a tal conjunto.

El vocablo Robot aparece en la década de 1920, el escritor Karen Capek lo usa en el texto de una obra teatral. Dicha palabra proviene de robota en eslavo y hace referencia al trabajo de forma forzada. Los progenitores directos del artefacto denominado robot en los años 1940, son los tele-manipuladores que se desarrollaron como aplicaciones al servicio de laboratorios que manipulaba material radioactivo sin riesgo para el operador. La introducción de los microprocesadores en los años 70 hizo posible que la tecnología de los robots haya alcanzado grandes avances. La intersección entre la mecánica y la electrónica hizo posible el robot actual (se habla de mecatrónica también). Los robots son programados con el fin que desarrollen desempeños repetitivos con cierto nivel de autonomía programada, en tal sentido son objetos electromecánicos controlados por computadoras.

Nam June Paik y Shuya Abe en el año 1964 completan el robot que denominan K456, diseño antropomórfico de componentes electrónicos el cual era manipulable por control remoto. Sus autores califican a K-456 como "primer artista de acción no-humano". Paik mediante su propuesta expandió el concepto robot como un objeto enmarcado en el campo del arte.

Se planteó al robot como objeto, con una funcionalidad espacial y temporal. Eduardo Kac usa el término "Art Robots" para hacer referencia a tales objetos. Artefactos con una dimensionalidad espacio-temporal abierta, diversa, que se expande y ocupa un lugar en el 
escenario expositivo abierto y cerrado. Se tipifican como agentes autónomos, autómatas de diversas morfologías, tele robots, prótesis robóticas y webots.

El robot tiene la capacidad de percibir al público, a su entorno y a su temporalidad por sí mismo. En ese sentido, dotado de sensores y respondiendo a partir de ellos y transformando los datos que recibe manifiesta comportamientos. "El comportamiento robótico puede ser mimético, sintético, o una combinación de ambos. Al simular aspectos físicos $\mathrm{y}$ temporales de nuestra existencia, los robots pueden inventar nuevos comportamientos.” (Kac, 1997)

El espacio de la robótica expandió sus posibilidades en tanto produjo objetos robóticos autónomos con cierta organicidad y niveles de interactividad con el público, con otras máquinas y con el ambiente. De ahí que se hable de una naturaleza conductual del robot, dada su capacidad de simular comportamientos e incluso aprender nuevos.

La condición interactiva del robot y las interacciones que establece con el público, el entorno e incluso otras máquinas determina o define las cualidades de la instalación. Las dimensiones espacio-temporales que lo contienen, la capacidad de procesar información y transformarla, la interacción que establece y determina comportamientos, la relación con el hombre y con otras máquinas hacen del objeto robótico un caso particular de interacción cuasi autónoma que le posibilita ser instalable o componente en sí mismo de instalación. La capacidad de hibridarse con diversas tecnologías mecánicas y electrónicas le posibilitan trascender su condición objetual a la vez que le permiten integrarse a su entorno y establecer relaciones con el mismo y con el público.

Eduardo Kac en su artículo Arte Robótica: Un manifiesto (1997) dice:” El arte robótica puede darse en espacios físicos, en el espacio telemático, en entornos virtuales o en cualquier combinación de estos espacios que incluya una ubicación real”. La robótica exige nuevas categorizaciones en el espacio del arte., encuentra en la instalación un espacio del cual partir y a partir del cual genera nuevas situaciones en términos de la interactividad y de la función que cumple en su relación con el espacio expositivo bien sea cerrado o abierto, al igual que con los espectadores. (Kac, 1997)

La robótica inaugura un nuevo género que establece relaciones cruzadas con el espacio de la instalación y a su vez lo trasciende o lo expande. Se dibujan horizontes 
heterodoxos en los que la tele presencia y la expansión de los limites reales lo ubican en los dominios de la telemática y la cibernética.

Eduardo Kac produce en el año 1998 un artículo en el cual de manera sucinta da cuenta del desarrollo del arte robótico y su incidencia en el arte contemporáneo. De dicho artículo la siguiente cita a manera de síntesis en torno al arte robótica, el lugar del artista y el público:

"En cuanto los artistas continúan ampliando los límites del arte, tradicionalmente circunscrito a la hechura de objetos discretos e inertes, ellos introducen la robótica como un nuevo medio de creación al mismo tiempo que desafían a nuestra comprensión de lo que es un robot, cuestionando nuestras premisas en la concepción, construcción y utilización de estas criaturas electrónicas. La relación del público con robots de diferentes tipos, mezcla de fascinación y temor, implica en aspectos emocionales, políticos y sociales inexplorados, particularmente aquellos comprendidos en el contexto del arte contemporáneo. El arte de robótica introduce el problema del modelaje del comportamiento (el arte crea no solo una forma sino un comportamiento) y torna posibles situaciones interactivas sin precedentes en espacios físicos o telemáticos (el objeto percibe al espectador y el ambiente)"7. (Kac, 1998)

La instalación robótica se configura entonces como un espacio-tiempo real y virtual en el cual se materializan estéticas en permanente cambio y reconfiguración, a partir de los nexos interactivos entre público y sistema, o entre sistema y otros sistemas, o entre máquinas y máquinas o entre máquina y ambiente.

\footnotetext{
${ }^{7}$ Tomado de Caderno da Pos Graduação, Instituto de Artes/Unicamp, Universidad Estadual de Campinas, año 2, volumen 2, 1998, pp. 18-28. Originalmente publicado en Art Journal, Vol. 56, No 3, Fall 1998, pp. 60-67, College Art Association, New York. Traducción del portugués: César Espinosa. Republicado parcialmente en: art.es, no 4, July/August 2004, Madrid, pp. 50-53 (inglés y Español).
} 


\section{Capítulo 4 Acerca del público}

\subsection{Sobre la relación entre autor y receptor}

En el siglo XX la relación autor - receptor fue objeto de estudio e investigación. Desde postulados modernistas y posmodernistas en distintos momentos y por diversos caminos se proclamó la "muerte del autor", afirmación contradictoria y problemática, sin embargo, las funciones de autor y receptor construidas en el siglo pasado, solo se comprenden en un contexto amplio de reflexión. Uno de los autores principales y pilar de este cuestionamiento es Mijaíl Bajtín (1895-1975), pensador ruso y teórico de la literatura. Plantea la relación autor - receptor en términos de igualdad. Amplía el horizonte estético, al plantear dicha relación como una relación dialógica enmarcada en prácticas culturales, filosóficas e históricas. Dicho investigador, en su momento introdujo la "crisis de la autoría" y esta crisis de autor no está relacionada con el creador o el espacio de la creación.

Propone expandir la mirada hacia la revisión del lugar del arte en el contexto de la cultura. Se comprende entonces al autor como parte fundamental de la obra; en ese sentido el individuo desaparece y ha de surgir en el contexto del receptor, en la medida de la recepción por parte del observador. Al respecto anota: "El autor no puede ni debe ser definido por nosotros como persona, porque estamos en él, vivenciamos su visión activa. (...) El autor ante todo debe ser comprendido a partir del acontecimiento de la obra como participante." (Bajtín, 1992, pág. 169). La mirada de un receptor activo se configura. El receptor participa del devenir de la obra. Se comprende al receptor en el sentido de completar la obra y esta completitud es activa y participativa, en tanto que, el receptor se aproxima a la obra desde una visión propia, con una perspectiva singular. Se asigna al acto de leer un rasgo de creación o mejor dicho una función co-creativa. El pensador ruso transforma al receptor en participante del acto creativo en tanto lo completa y le da existencia y lo valora visionariamente como un acto de interacción: "El complejo acontecimiento del encuentro y de la interacción con la palabra ajena (...) El objeto verdadero es la interacción y la relación mutua entre los espíritus.” (Bajtín, 1992, pág. 366)

Es importante anotar que, en la reflexión en torno al texto, el autor, el receptor y el entorno, continuó su desarrollo en diferentes ámbitos del pensamiento. El concepto de texto se amplió y se generalizó hasta abarcar la obra artística en sus diversas manifestaciones. 
Autores como Lévi-Strauss, Lacan y Derrida abordaron la reflexión al respecto en sus producciones textuales. En el caso de las artes visuales dichas preocupaciones estuvieron presentes y se pueden identificar en la producción de los años sesenta en fenómenos como el arte conceptual, el arte cinético y el arte participativo. La cuestión referida a la relación entre receptor y autor más allá de ser un nuevo enfoque, se concreta como un cambio de paradigma. La reflexión amplía el horizonte incluyendo el contexto, los elementos gramaticales y semánticos en el texto de la obra.

Desde las teorías semiológicas y estructuralistas se hacen aportes a la triada artistaobra-observador, al focalizar la visión desde el fenómeno de la recepción como parte importante y fundamental en la construcción de la obra. La mirada semiológica enfatiza que la obra adquiere significado por medio del acto de la recepción, mientras que desde la mirada estructuralista se cuestiona la autoría individual de la obra dado que la obra se inserta en un contexto concreto en un sistema dado. A partir de estos puntos de partida se dibujaron en el siglo XX dos posturas diferentes al respecto: "la muerte del autor" como lo propuso en su momento Roland Barthes; o la reformulación que planteó la teoría estética de la recepción desde Wolfgang Iser y Hans Robert Jauss.

La estética de la recepción aborda como un proceso de comunicación la articulación de la relación autor-obra-receptor. A diferencia del abordaje estructuralista carente de contexto y centrado en la obra misma, la estética de la recepción teniendo a Bajtín como precursor se apoya en la noción de historicidad; libera el discurso estético de su autorreferencialidad y desplaza el problema más allá del análisis de la obra en ella misma. Otros factores de análisis se construyen y se insertan en la mirada referida al fenómeno estético, factores tales como el contexto histórico, el entorno cultural y el receptor entre otros.

Iser y Jauss aportan desde sus reflexiones argumentos que consolidan la recepción como el pilar de la conversión del objeto en obra; se emparenta esta noción con los hallazgos de Bajtín en los años veinte referidos a la interacción obra-receptor. Jauss argumenta que el horizonte interno de la obra está definido y determinado por la obra misma; y que el horizonte externo de la obra relacionado con el receptor y el proceso mismo de la recepción siempre es contextual, dado que el receptor en su marco de subjetividad es determinado por la época y la cultura en la cual vive. Iser aunque comparte los anteriores argumentos expande la visión al plantear la manera como la obra afecta al receptor a partir de lo que él denomina “...triple 
avance dialéctico del texto, el lector y la interacción que sucede entre ellos.” (Iser, 1987, pág. 12) La obra ajena distante y cerrada, ahora en el escenario de la estética de la recepción sufre una transformación en la cual, el fenómeno de la interacción ocupará un lugar central y determinante en la transformación del objeto en obra.

En los setenta la discusión y reflexión respecto al fenómeno del autor-único y receptor-participante sigue viva. Bajtín ya a comienzos del siglo sentó las bases para esta reflexión. Iser planteó un par de términos los cuales abrieron un horizonte de posibilidades para el receptor. De una parte, planteó "la virtualidad de la obra" al incorporar los conceptos de "obra abierta" y dinámica que sustentan que el receptor activa y pone en marcha la obra, el texto, el espacio lleno- vacío y la concreta desde una perspectiva dialógica; por otra parte, el proceso de lectura es dinámico en tanto el lector provee de significado potencial al texto. 8

Las teorías que sustentaron la noción de autor y receptor se fundamentaron en un par de hipótesis a saber: la centralidad del discurso en la obra cerrada y conclusa, y la que asigna al receptor una función interpretativa que da sentido y significado a la obra. Las hipótesis que devinieron de las visiones de la estética de la recepción, si bien generaron una apertura al análisis y reflexión en torno al fenómeno de recepción, se quedaron cortas frente a los desarrollos creativos que después de los sesenta los artistas propusieron a partir del cruce entre ciencia, tecnología y arte. El desarrollo de los procesos interactivos y telemáticos en el arte electrónico por parte de los artistas e investigadores, generó nuevas perspectivas que perfilaron y tipificaron de diversas maneras la actuación del público.

Las instalaciones interactivas, robóticas y multimediales permiten la participación, no solo desde una forma mental o sicológica - como lo sugirió en su momento la estética de la recepción - sino que por el contrario estas instalaciones, conciben la participación de manera explícita y factual.

Ya desde el arte cibernético sustentado en la comunicación bidireccional se replanteó la actitud pasiva del espectador. La preocupación por parte del artista de los roles posibles que el receptor puede asumir es una cuestión central en el diseño de las instalaciones

\footnotetext{
${ }^{8}$ Umberto Eco planteó en Obra abierta la presencia de elementos no presentes en el texto a los que llamó "elementos no dichos" y concretó el concepto de "lector modelo" que participa en la interpretación de la obra. De manera similar referencia al receptor como usuario.
} 
estudiadas. Igualmente, las relaciones y diálogos que la obra puede suscitar, no solo con el público, sino también con el entorno, el espacio museístico y la obra misma.

$\mathrm{El}$ arte electrónico posibilita la apertura de la obra. Es posible la intervención directa, la posibilidad de modificarla, perturbarla, activarla, incluso la de generar procesos aleatorios que lleven incluso a la destrucción del sistema o a la circularidad creativa de la obra, mediante bucles iterativos que desencadenan nuevas posibilidades formales en el espacio instalativo, en la obra misma y por ende en la relación con el público y sus desempeños posibles. 


\subsection{Sobre la relación entre el público y arte electrónico}

El arte electrónico implicó cambios radicales en la percepción, recepción y circulación de este tipo de obras. Las ideas estéticas y centradas en el objeto de arte como elemento puramente matérico, como algo original, autónomo, producto de la genialidad y en relación con un público tradicional, son revaluadas dadas las características propias del arte electrónico. Afirma Claudia Giannetti: "La obra de arte electrónico interactiva exhorta el paso desde la teoría estética clásica, centrada en el objeto de arte hacia una nueva teoría que tiene como punto de referencia principal al interactor." (Giannetti C. , 1999)

Las instalaciones interactivas y robóticas del presente estudio cuestionan la actitud pasiva del público frente a la obra garacias a la formulación de las propuestas mismas, su diseño y sus interfaces; propuestas que motivan de manera directa en algunos casos e indirecta en otros la participación del público. Las instalaciones se abren a la información proveniente de distintas fuentes como son: el entorno, el receptor, los datos estadísticos, el Internet, el cuerpo, el movimiento, o los fenómenos físicos entre otros.

Los procesos de interacción introducidos por el arte electrónico, así como sus búsquedas referenciales, experienciales e investigativas, transformaron el papel del público en relación con la obra de arte. La intencionalidad de los artistas es observable, no solamente en el constructo conceptual, sino también en el diseño del sistema, la interfaz y las maneras como se procesa la información. Igualmente, dicha intencionalidad propició una relación dialógica con el público, la cual expandió los vínculos posibles entre obra y receptor por caminos novedosos y creativos, apoyados en la ciencia y la tecnología.

El arte electrónico favoreció el establecimiento de una comunicación abierta que trascendió la relación tradicional entre público y obra, para instalarla en una relación de interdependencia y complementariedad en la cual las nociones de autor, obra, sistema, interfaz, público y máquina se contextualizaron en un escenario nuevo.

Las artes de la participación, artes de la acción comprenden tendencias en las que el público abandona su rol tradicional, separado de la obra para pasar a ser partícipe de la dinámica propia de la obra. (Nusenovich, 2000)

En la experiencia interactiva de las instalaciones interactivas y robóticas analizadas se ve de manera manifiesta la complementariedad e interdependencia entre el artista desarrollador y el receptor activo, quien mediante acciones y experiencias de diversa índole 
interactuó dentro y fuera de los escenarios de la obra. El público actúa a la vez desde una perspectiva exógena y endógena en el espacio/tiempo de las instalaciones, desempeñándose simultáneamente en una realidad física y otra virtual como sujeto y como objeto.

La secuencia acción-reacción, característica de los sistemas interactivos estuvo presente en las instalaciones citadas. A la actuación de los participantes le sucedieron respuestas que avizoraron una cascada de futuros inmediatos provenientes del sistema que soporta las obras. Las respuestas del sistema a su vez condujeron al espectador a desempeñar nuevas acciones que provocaron otras reacciones, lo cual podría generar contravenciones o confirmaciones de las expectativas del artista en cuanto al diseño de su obra.

Como se verá más adelante, definitivamente el rol del público en la mayoría de las obras estudiadas se distanció del rol museístico tradicional y se dibujaron horizontes en los que se expandieron nuevos conceptos para tipificar la participación activa del mismo. 


\subsection{Sobre la intencionalidad del artista y la participación del público}

En el desarrollo del análisis de las obras se ahondará en diversos aspectos referidos a las instalaciones, los artistas y su intencionalidad, para provocar nuevas actuaciones de parte del público tradicional. A continuación, un par de alusiones respecto a la intencionalidad de los artistas para propiciar la participación del público.

Cuando en la instalación robótica hay concordancia entre el devenir de los datos y la conexión con el mundo real del público se produce cierta convergencia que genera un efecto de inmersión, como es el caso de la obra Generación de Conciencia I - 2011. (Daniel Álvarez, Diego diez y Daniel Álvarez Olmedo), instalación en la cual se propicia una interacción física con el público mediante una manilla vibratoria que el participante puede instalarse. Esta vinculación momentánea entre la manilla y el cuerpo se trasforma en prótesis en la medida que se comporta como prolongación que posibilita la experiencia de adentrarse en la obra, dicha manilla vibratoria se constituye en un amplificador del tacto pasando de sujeto a objeto de manera alternada.

(...) “en las instalaciones, la mayoría de las veces, la sensación inclusiva en la obra se logra no por efecto de ingresar a un espacio sino por efecto de la inclusión de un sujeto en un dispositivo, y es el dispositivo el que actualizará las estrategias de producción y recepción que ha pautado a priori el artista." (García, 2007, pág. 104)

Existe un nivel de intencionalidad por parte de los artistas productores de estas instalaciones. Intencionalidad consistente en interrelacionar el público de la escena de la ciudad de Buenos Aires con el contexto específico del arte electrónico a través de medios y tecnologías que emplean códigos, los cuales se constituyen en un repositorio de signos, gramáticas y significados. El receptor en el desempeño de su papel habita los contextos en los que interactúa. Significa que como tal puede tomar distancia de sí mismo y de la instalación, así como participar y sumergirse con un alto grado de compromiso en los procesos activadores que el artista ha diseñado. Iliana Hernández expresó: "La interactividad tiene por objetivo permitir la experimentación sensorial y especialmente cognitiva de un mundo virtual emergente, es decir nuevo, inédito, que inclusive es aún más nuevo cuando se libra al azar de la interacción de los usuarios y a la multiplicidad en la interpretación que esto conlleva.” (Hernández, 2009, pág. 45) 
En las instalaciones robóticas Proxemia - 2002 (Mariela Yeregui) y Espacio Cambiario - 2010 (Leo Núñez) se pudo observar como los robots evolucionan en tiempo real y de manera progresiva a causa de las propiedades comportamentales que le han sido asignadas. A causa del movimiento, en la obra Proxemia robots, entorno y público desempeñan un papel relevante, ya que se causan mutuamente interferencias a nivel comportamental, tanto individualmente como grupalmente, interferencias que se ven exteriorizadas en las trazas de movimiento y relación que se suceden, como si se tratara de seres biológicos. En el caso de Espacio Cambiario los robots evolucionan en tiempo real a partir de información externa proveniente de la Internet o de bases de datos sin que el espectador intervenga para ello. Se observan entonces dos niveles de relación. Un primer nivel referido al proceso de comunicación entre los robots y las bases de datos y un segundo nivel dependiente de los sensores que potencian la capacidad del software para procesar la información.

Vemos pues como los artistas con la ayuda de sus obras y presupuestos conceptuales y mediante el uso tecnológico provocan actuaciones participativas, no solo a nivel de la interacción dinámica en el espacio/tiempo de la instalación sino, que generan preguntas en el imaginario del contexto respecto a las temáticas tratadas por la obra.

Se facetan entonces roles que podríamos llamar objetivos y observables como, por ejemplo: movimientos, desplazamientos intencionales e interconexiones con la obra. De igual manera otros roles que podríamos llamar subjetivos, en tanto la obra cuestiona al participante y propicia su reflexión, asombro y curiosidad, lo cual se evidencia en el regresar a la instalación con el fin de indagar y experienciar en el conjunto de lógicas y gramáticas puestas en escena por el artista. En síntesis, se evidencia la estrecha relación existente entre el público, la obra, el contexto y el artista que provoca la generación de sentido, significado y comunicación a través del rol activo del público.

Con base en la argumentación expuesta en los apartados anteriores, se propone a manera de hipótesis que las obras de arte electrónico colocan al público como una variable activa, donde dicha categoría se resignifica según el lugar de emplazamiento que le adjudica el artista y/o la obra. El análisis del corpus seleccionado, ofrece evidencia suficiente para tipificar en la escena local de Buenos Aires del período comprendido entre 2002/2012, la configuración de roles en el público como los de usuario, actor e interactor. 


\subsection{Posibles roles - Tipificaciones}

A continuación, teniendo como base diversos autores y para efecto del análisis de las obras, se trata de precisar la diversidad relevante de términos que hacen referencia al receptor,

1. Público

2. Espectador

3. Observador

4. Actor

5. Usuario

6. Interactor

Lo anterior con el propósito de definir y aclarar dichas nociones para efectos de la presente investigación y sin pretender con ello agotar las múltiples y diversas alternativas que se podrían configurar en diversos contextos y las cuales están en permanente construcción.

\subsubsection{Público}

Termino amplio y generalizante, con diversas acepciones, que hace referencia según la definición del Diccionario de la lengua española a:

1. Conjunto de las personas que participan de unas mismas aficiones o con preferencia concurren a determinado lugar.

2. Conjunto de las personas reunidas en determinado lugar para asistir a un espectáculo o con otro fin semejante.

La noción público, entendida como la presencia que entra en relación con la obra. Presencia en estado potencial, latente, en tanto no interactúa con el diseño de la obra, en tanto no perturba el estado de equilibrio inicial del espacio/tiempo instalativo. A diferencia del término espectador, el cual se relaciona estrechamente con el ver o mirar detenidamente algo. El término escrutado no se circunscribe a la esfera visual, sino que la trasciende en el sentido de la corporeización que implica la presencia. 
Este rol en el presente estudio se tomará desde la acepción general del que asiste y participa en el espacio instalativo, con la intención de acercarse y dejarse permear por las intenciones del artista a través del diseño de la obra. Público en tanto se sitúa en uno de los extremos de la relación público/obra y público/artista.

\subsubsection{Espectador}

En el Diccionario de la lengua española encontramos que espectador, del latín spectātor, -ōris. Se define como quien mira con atención un objeto, o quien asiste a un espectáculo público.

Afirma Jonathan Crary: "La palabra "espectador" conlleva connotaciones específicas, concretamente, las de ser el asistente pasivo de un espectáculo, como en una galería de arte o en un teatro." (Crary, 2007, pág. 26)

Jacques Rancière desde otra perspectiva, en su libro El espectador Emancipado presenta dos paradigmas del teatro en los cuales el espectador asume dos roles diferentes, de un lado, el teatro de la crueldad de Antonin Artaud, donde el espectador debe ser parte de la obra en alguna medida, ser el centro de la actividad, e involucrarse con lo que está siendo escenificado; por otro lado, y de manera distinta, el teatro de Bertolt Brecht, que plantea el distanciamiento crítico, en el cual el espectador no se involucra emocionalmente para no afectar el sentido reflexivo del asistente. En el ensayo El espectador Emancipado se revisa la noción de espectador desde el teatro. La noción de un espectador extático en contraposición a la del actor, es cuestionada por Rancière en tanto en el proceso de mirar también hay acción,

el espectador "observa, selecciona, compara, interpreta" (Rancière, 2010) es un alguien que decide qué hacer con lo que se escenifica delante de sus ojos. Se plantea la oposición entre el mirar y el actuar, de cómo la estructuración de relaciones entre decir, ver y hacer proviene de la estructura de la dominación y la sujeción.

El llamado arte participativo en el cual el receptor es parte fundamental del hecho artístico ha propiciado un tránsito de la noción de espectador tradicional, a la de un individuo productor de sentido de la obra. La recepción participativa presupone una relación estrecha con la obra en la cual el espectador se involucra física, mental o socialmente con la propuesta. 
Se habla entonces de un espectador dinámico en la medida que es receptor y creador de sentido.

Claudia Giannetti considera que la noción de espectador en tanto pasiva y distanciada no se ajustan ni al rol, ni a las relaciones que el público asume en su relación con el arte electrónico y en particular con las instalaciones interactivas, por lo tanto, se requiere de otras nociones que den cuenta de dichos intercambios.

La noción de espectador al igual que las de los otros términos aquí tratados, es ambivalente y por extensión o expansión ha adquirido nuevos matices. Sin embargo, aquí en este estudio se tomará el vocablo espectador desde la acepción general del que asiste y presencia un espectáculo, en el sentido que Jonathan Crary le asigna cuando afirma: "La palabra "espectador" conlleva connotaciones específicas, concretamente, las de ser el asistente pasivo de un espectáculo, como en una galería de arte o en un teatro." (Crary, 2007, pág. 26) Igualmente en el sentido de Claudia Giannetti cuando afirma respeto a los términos espectador y observador: “...desde el punto de vista de la relación entre receptor y obra, tienen una connotación contemplativa y distanciada, y por lo tanto, son inadecuados para expresar el vínculo interactivo entre ambos.” (Giannetti C. , 2002, pág. 105)

\subsubsection{Observador}

Con relación a la noción de observador, se fundamenta la pesquisa en los estudios y reflexiones llevados a cabo por Jonathan Crary (2008) y consignados en el libro Las técnicas del observador: visión y modernidad en el siglo XIX. Como dice el autor "Este es un libro sobre la visión y su construcción histórica.” (Crary, 2007, pág. 15)Igualmente se tomarán referencias de otros autores como Peter Weibel y Claudia Giannetti.

Plantea Crary, J. Como el desarrollo de la ciencia, la tecnología y en particular las técnicas infográficas han reconfigurado de manera profunda las relaciones entre el observador y los modos de representación, produciendo nuevos significados para los términos observador y representación. El advenimiento del ordenador genera la posibilidad de producir imágenes desde un lugar diferente a como lo había hecho desde sus facultades miméticas el cine, la fotografía y la televisión. Los procesos de visualización se modifican debido al impacto de las tecnologías emergentes. Sin embargo, el modo de ver del observador 
pasivo convive junto a modos de ver nuevos en los cuales se trasciende la actitud pasiva y contemplativa del sujeto. 9

Los términos observador y espectador comúnmente son usados como sinónimos. Sin embargo, etimológicamente vistos difieren dado que sus raíces latinas van en direcciones diferentes. La procedencia de la palabra observar es del latín: observare cuyo significado es poner atención en, acechar, espiar, vigilar, cuidar. (guardar, prestar atención, mantenerse fiel). En este sentido Crary J. Dice "Aunque se trate obviamente de alguien que ve, un observador es, sobre todo, alguien que ve dentro de un conjunto determinado de posibilidades, que se halla inscrito en un sistema de convenciones y limitaciones." (Crary, 2007, pág. 21)

La participación del sujeto observador, incorpora el cuerpo a la actividad perceptiva, es decir, la subjetividad en el acto de ver como forma de participación. Afirma Jonathan Crary que la modernidad se ocupa del tratamiento formal de la superficie de la imagen y no de la realidad representada. De esta forma, el modelo renacentista de observador basado en la cámara oscura se debilita, la cámara oscura entendida como, “...un aparato que garantizaba el acceso a una verdad objetiva acerca del mundo" (Crary, 2007, pág. 25). El individuo en la modernidad se vincula al acto de ver, configurando la noción de un observador subjetivo que escruta, participa y se somete a unos códigos de representación. En resumen, Crary plantea al observador como un individuo participativo, en tanto se involucra con los dispositivos mediáticos que utiliza, depende de un contexto de recepción y las experiencia con toda su subjetividad. Con su mirada se reconoce como observador, asume las reglas que el medio propone y a su vez permite conscientemente el ser atraído por la ilusión del dispositivo y sus

9. La mayor parte de las funciones históricamente importantes del ojo humano están siendo suplantadas por prácticas en las que las imágenes visuales ya no remiten en absoluto a la posición del observador en un mundo «real», percibido ópticamente. Si puede decirse que estas imágenes remiten a algo, es a millones de bits de datos matemáticos electrónicos. La visualidad se situará, cada vez más, en un terreno cibernético y electromagnético en el que los elementos visuales abstractos y los lingüísticos coinciden y son consumidos, puestos en circulación e intercambiados globalmente. Crary, J. (2008). Las técnicas del observador: visión y modernidad en el siglo XIX (No. 4). Cendeac. p.16 
convenciones. 10

Claudia Giannetti afirma: "Observador y espectador son términos que, desde el punto de vista de la relación entre receptor y obra, tienen una connotación contemplativa y distanciada, y por lo tanto, son inadecuados para expresar el vínculo interactivo entre ambos." (Giannetti C. , 2002, pág. 105). Espectador y observador son términos que tienen una significación pasiva y contemplativa en la relación obra - receptor, desde el concepto estético kantiano que plantea el efecto o influjo de la obra sobre el espectador u observador. El espectador en tanto sujeto que escruta o contempla bien sea la naturaleza o la obra de arte, lo hace desde su condición de sujeto y en esa misma instancia subjetiviza dicha relación.

Desde otra perspectiva Peter Wiebel, en el texto El mundo como interfaz plantea que somos un observador interno, sin embargo, respecto de los mundos generados tecnológicamente, el público de una instalación interactiva puede a la vez ser un observador interno y externo, la anterior afirmación apoyándose en la teoría de los sistemas y la noción de la Endofísica establecida por Otto E. Rössler. Wiebel estudia y reflexiona el fenómeno del observador, las posibilidades acerca del observador interno, de la interfaz, de la construcción de espacios y realidades virtuales. En las instalaciones interactivas propuestas por Weibel el público adopta la forma de observador haciendo parte de sistema que observa, con el cual establece una relación de interacción mediante los dispositivos electrónicos los cuales son

\footnotetext{
${ }^{10}$ La mayor parte de los diccionarios hacen pocas distinciones semánticas entre las palabras «observador» y «espectador», y el uso común a menudo los convierte, de hecho, en sinónimos. He elegido el término observador principalmente por sus resonancias etimológicas. A diferencia de spectare, raíz latina de «espectador», la raíz de «observar» no significa literalmente «mirar a». La palabra 'espectador' también con- lleva connotaciones específicas, especialmente en el contexto de la cultura decimonónica, que prefiero evitar concretamente, las de ser el asistente pasivo de un espectáculo, como en una galería de arte o en un teatro. En un sentido más pertinente para mi estudio, observare significa «conformar la acción propia, cumplir con», como al observar reglas, códigos, regulaciones y prácticas. Aunque se trate obviamente de alguien que ve, un observador es, sobre todo, alguien que ve dentro de un conjunto determinado de posibilidades, que se halla inscrito en un sistema de convenciones y limitaciones. Y por «convenciones» pretendo sugerir mucho más que prácticas representacionales. Si puede decirse que existe un observador específico del siglo xix, o de cualquier otro período, lo es solo como efecto de un sistema irreductiblemente heterogéneo de relaciones discursivas, sociales, tecnológicas e institucionales. No existe un sujeto observador anterior a este campo en continua transformación. Crary, J. (2008). Las técnicas del observador: visión y modernidad en el siglo XIX (No. 4). Cendeac. p.26
} 
considerados inherentes al sistema y sus procesos. El observador de Weibel es activo, participativo, establece una relación de interacción con la interfaz y el sistema mismo.

Como se ha expuesto sucintamente (sin pretender ser exhaustivos, ni agotar el tema dado que es un término en permanente construcción y reconstrucción), la noción de observador ha sido tratada desde diferentes puntos referenciales; desde un observador distante y subjetivo, a un observador determinado por los avances tecnológicos, científicos, artísticos y determinado por las formas de ver que han devenido de dichos aparatos o dispositivos.

Para efectos del análisis de las instalaciones interactivas y robóticas aquí tratadas se dará tratamiento de observador al público, en el caso de aquellas instalaciones en que el dispositivo electrónico o el diseño del artista no interactúa con el público, y viceversa en que la presencia y participación del público no activa ni determina el devenir abierto de la instalación. Siendo el caso, el de aquellas instalaciones que reciben inputs desde bases de datos estadísticos, las cuales se activan y establecen relaciones dialógicas con la información que devienen de dichas bases de datos o de la Internet.

\subsubsection{Usuario}

La noción de usuario ha sido transitada por diversos autores, a continuación, algunos acercamientos a dicha noción. En el texto de Umberto Eco Obra Abierta de los años sesentas, el autor utiliza el término usuario para hacer referencia al término receptor utilizado en las reflexiones que hicieron sobre el texto autores como Bajtin, Iser y Jauss.

Umberto Eco observa respecto a una obra de Bruno Munari:

“Además, Bruno Munari ha ideado un nuevo y original género de pintura en movimiento de efectos verdaderamente sorprendentes: proyectando mediante una simple linterna mágica un collage de elementos plásticos (una especie de composición abstracta obtenida superponiendo o arrugando hojas muy delgadas de material incoloro al que se ha dado diversas formas) y haciendo pasar los rayos luminosos a través de una lente polaroid, se obtiene sobre la pantalla una composición de intensa belleza cromática; haciendo luego rodar lentamente la lente polaroid, la figura proyectada empieza a cambiar gradualmente sus propios colores pasando a través de toda la gama del arco iris y realizando, a través de la reacción 
cromática de los diversos materiales plásticos y de los diversos estratos en los que se componen, una serie de metamorfosis que inciden incluso en la misma estructura plástica de la forma. Regulando a su gusto la lente que gira, el usuario colabora efectivamente en una creación del objeto estético, por lo menos en el ámbito del campo de posibilidades que le permiten la existencia de una gama de colores y la predisposición plástica de las diapositivas.” (Eco, 1990, pág. 48)

En el ejemplo, el concepto de usuario referencia al individuo, que en su relación con la obra, la manipula de manera directa produciendo diversas posibilidades de configuración y visualización de la misma. Usuario en tanto manipula y perturba un estado inicial de la obra y lo trastoca en diversos estados a partir de las lógicas propuestas por el artista.

Lev Manovich el teórico de los nuevos medios nos dice que la intervención del usuario está mediada por distintos componentes y se puede dar de diversas formas, al respecto enumera los siguientes: “...interactividad por menús, la escalabilidad, la simulación, la interfaz de imagen, la imagen instrumento, para describir diferentes clases de estructura y de operaciones interactivas." (Manovich, 2005, pág. 87)

En otra dirección desde los nuevos medios se ha utilizado la palabra usuario en términos de la función de uso que este hace del ordenador, al respecto Rodrigo Alonso, propone sustituir el término "espectador" por "usuario" cuando dice:

"El participante de una instalación interactiva no puede llamarse espectador. $\mathrm{Su}$ relación con la pieza ya no se basa en la contemplación, sino que requiere un compromiso mayor: no solo visual o intelectual sino también físico. Las instalaciones interactivas parten de un estado potencial que no se pone en marcha hasta que alguien lo activa, manipula o interfiere. Sin las acciones concretas del visitante, la pieza permanece en un estado de latencia, en un estado germinal incapaz de completar las posibilidades de las que la ha dotado su creador. Por tal motivo, hay que hablar de usuarios y no de espectadores: los participantes de una obra interactiva deben hacer uso de ella, operarla, estimularla; de otra manera la pieza carece de todo sentido y función.” (Alonso, 2005, pág. 51)

Claudia Giannetti plantea a diferencia de Alonso lo siguiente: "La palabra "usuario" comúnmente proviene de la función de "uso" que la persona hace del ordenador u otro 
aparato que no es necesariamente una acción interactiva". (Giannetti C. , 2002, pág. 105) y más adelante en el mismo texto define usuario de la siguiente manera:” Persona que usa un sistema informático y sus programas de aplicación para realizar tareas y producir resultados. Se habla de usuario de la red, en referencia a las personas que están conectadas a Internet” (Giannetti C. , 2002, pág. 197)

Como se puede observar, en la indagación acerca del término usuario, la noción de usuario deviene de las teorías de la información, la estética de la recepción y adquiere utilidad en el campo de la informática a través del uso masivo del ordenador.

Para efectos de la presente investigación se denomina al público de las instalaciones interactivas y robóticas usuario, cuando la relación que establece con el dispositivo se origina a partir de una instrucción puntual que generalmente es visible, evidente y está escrita en una nota de programa y la cual induce al público a asumir un rol de uso. Es decir, la participación del usuario está mediada por un conjunto de instrucciones, que al seguirlas producirán la activación de la instalación y los mecanismos del sistema diseñados por el artista. Generalmente dichas instrucciones implican la manipulación directa del dispositivo en cierto orden o con cierto nivel de jerarquización, y es en esa mediada que la interacción se produce y los efectos esperados por el artista se suceden o no.

\subsubsection{Actor}

Las reflexiones en torno a la instalación han indagado la relación entre el receptor y la obra. Dentro de esas variadas reflexiones, se perfiló la noción de un público que se adentra físicamente y experimenta la instalación, en esa medida se perfila la idea de dispositivo escénico que permite configurar la noción de actor para el participante. En el anterior sentido es que María Silvina Valesini en su tesis de maestría sustentó dicha noción. La relación entre el espectador y el escenario en el ámbito teatral ha estado mediada por la clara delimitación entre el espació de escenificación de la obra y el espacio designado para el que asiste a la función. Al respecto Valesini afirma:" Cuando esa delimitación se altera, para posibilitar la interacción de un espectador que pueda llegar a modificar el flujo de la acción, este pierde su condición de tal para asumir el rol de actor, borrando de este modo el límite entre lo real y lo ficcional.” (Valesini, 2014, pág. 57) 
Las instalaciones interactivas y robóticas aquí estudiadas, son posibles de ser vistas desde lo que Josu Larrañaga (2001) ha llamado escenografías descentradas y que Valesini las describe como: “...arquitecturas efímeras(...)a disposición de eventuales estrategias de uso e interacción(...) desplazan el punto de vista al interior de la obra, lo activan y multiplican en relación a un actuar encarnado por cada espectador, a través de una mediación enteramente corporal." (Valesini, 2014, pág. 101)

Valesini concluye en su estudio lo siguiente:

"Por eso la asignación de la nueva categoría de espectador-actor pretende dar cuenta de la intervención de este en la naturaleza ficcional de lo imaginario y de lo estético, que inaugura una nueva dimensión de la percepción y experimentación del mundo, a partir de la convergencia entre la materialidad de la obra, su propio cuerpo y el cuerpo del otro.” (Valesini, 2014, pág. 119)

Para efectos de la presente investigación se denomina al público actor, cuando este, a través de una actuación performática (motivada por la instalación) establece un intercambio dialógico con el dispositivo instalativo, mediante la mediación de una interfaz no explícita, que es capaz de leer los movimientos, acciones o actuaciones del actor y modificar el estado de latencia potencial de la instalación, para de este modo, propiciar la activación del diseño del sistema propuesto por el artista.

\subsubsection{Interactor}

La noción de interactor aparece por primera vez en el texto publicado en el catálogo de Ars Electrónica 92. En este catálogo se hace referencia a la obra Electronic Purgatory, propuesta de teatro digital interactivo creada por Kristi Allik y Robert Mulder. En el texto, la noción de interactor hace alusión al público que activamente participa, se relaciona e interactúa con la obra a través de una conexión directa con el sistema mediada por una interfaz. Claudia Gianetti se refiera a los sistemas interactivos digitales como sistemas complejos, abiertos y pluridimensionales, y desde ahí hace un tránsito de la noción de receptor a interactor y lo tipifica como el que (....además de -actuar- mentalmente en el espacio de la obra), desempeña un papel práctico fundamental en la propia efectivación de la misma." (Giannetti C. , 2002, pág. 105) 
Para efectos de la presente investigación se denomina al público de las instalaciones interactivas y robóticas interactor, cuando en el contacto con la obra se establezca una relación dialógica, activa y participativa bien sea a nivel físico o virtual, mediada por una interfaz explícita. Interacción que se sucede, por el hecho mismo de ingresar en el espacio/tiempo instalativo y que a su vez denota interactuar de manera práctica con el sistema y la interfaz propuesta por el diseño de la obra, con el fin de activar los procesos potenciales que el artista ha diseñado para tal fin.

Es importante aclarar que cuando los roles del público se tipifican de las distintas maneras expuestas en el apartado anterior, se destaca un modelo distinto de interacción al que se propuso, por las estéticas cibernéticas, comunicacionales o de la recepción como se estudió en capítulos precedentes. Hablamos entonces de instalaciones interactivas y robóticas permeables, de estructura abierta, de obras que subvierten el sistema objetual y en las cuales se establecen redes dialógicas entre obra-contexto-público mediadas por canales de entrada, salida y feedbacks, propiciando la expansión hacia diversos roles. 


\section{Capítulo 5 Análisis de obras}

\subsection{Instalaciones interactivas}

\subsubsection{Sensible - instalación interactiva - Grupo Biopus}

A continuación, texto descriptivo de la instalación, el cual al igual que las imágenes han sido tomadas del sitio Web del Grupo Biopus:

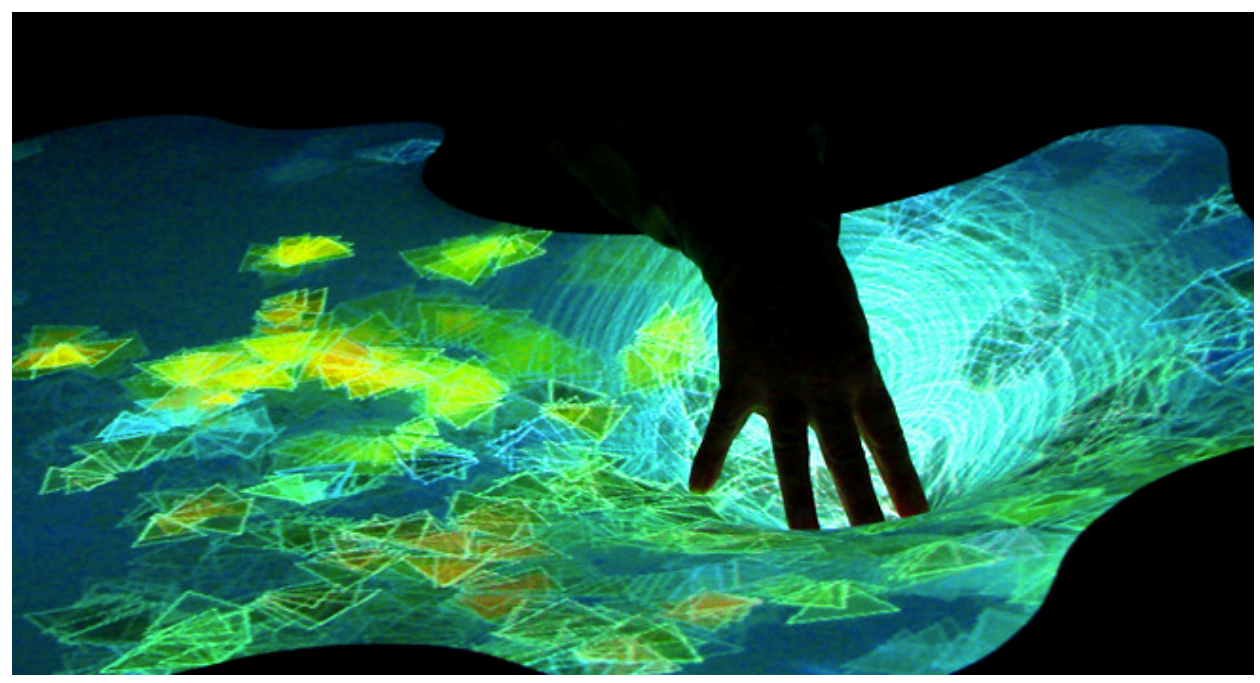

Ilustración 1 - Gesto interactivo. Sensible, instalación interactiva. Grupo Biopus.

"Sensible es una instalación interactiva, dotada de una pantalla sensible al tacto, que permite a las personas manipular un ecosistema virtual y, a partir de esta acción, producir música en tiempo-real. En función de los distintos tipos de intervenciones realizadas por los participantes, los algoritmos de vida artificial, desarrollan un ecosistema virtual que produce, a su vez diferentes ambientes musicales. El ecosistema de Sensible se conforma de tres tipos diferentes de organismos virtuales: los vegetales, los herbívoros y los carnívoros. Los vegetales (círculos) son incapaces de moverse o devorar a otros organismos. Los herbívoros (triángulos) pueden desplazarse y necesitan comer vegetales para permanecer vivos. Los carnívoros (rectángulos) pueden desplazarse y necesitan comer herbívoros para permanecer vivos. Todos los organismos, consumen energía que, en el caso de los herbívoros y carnívoros, deben recuperar alimentándose. Cuándo un organismo se 
mueve, consume mucha energía. Estas leyes hacen que cada organismo deba tomar decisiones a la hora de moverse y procurarse su alimento. El ecosistema de Sensible es un "sistema cerrado" y como tal tiende rápidamente al desequilibrio. La única forma de mantener su equilibrio, es a través de una gran inversión de energía desde fuera del sistema, es decir, a través de la participación del público. Por eso, las personas son las encargadas de regular este ecosistema y su evolución. Para crear cada tipo de organismo, las personas deben intervenir con distintos gestos sobre la pantalla sensible. La música de Sensible, se genera a través de algoritmos de composición en tiempo-real que evalúan diferentes variables del ecosistema para producir el material sonoro. La densidad de población, la cantidad de energía que despliegan los organismos en sus acciones, así como los niveles de placer y displacer de cada organismo (en función de lograr sus objetivos, como alimentarse o no ser atrapado por un depredador), son las variables del ecosistema que rigen la evolución de la trama musical." (Biopus, 2007)

La obra Sensible se tipificó como instalación interactiva. Se enmarcó en procesos de investigación en torno al arte electrónico, la interactividad y la articulación entre imagen y sonido. Respecto a dichos procesos sus integrantes afirmaron: "En nuestra producción dentro del grupo Proyecto Biopus (www.biopus.com.ar) tuvimos la oportunidad de realizar algunos trabajos que nos enfrentaron a problemas relacionados con la articulación de la imagen y el sonido en función de nuevas estructuras y formatos.” (Biopus, 2007, pág. 1) Sensible implicó desarrollos experimentales en torno a fenómenos en principio desconexos, los cuales a través del proceso de investigación y experimentación llevados a cabo encontraron maneras de formalización y expresión estética como la que se materializó en la instalación interactiva Sensible.

Temáticamente en la instalación convergieron conceptos que hacían referencia a algoritmos de simulación de vida artificial, generación de ecosistemas, composición musical, equilibrio, desequilibrio y energía. Abarcó un horizonte amplio de metáforas referidas a la vida en relación con los comportamientos de seres virtuales y humanos involucrados en procesos dialógicos e interactivos.

El público en razón a la participación y el diseño que la obra propuso, se tornó en un participante creativo, en cuanto, el artista le asignó dicha atribución, la cual se manifestó y 
concretó a través de la interacción misma con la obra. Emiliano Causa sobre la cuestión de la coautoría expresó el siguiente punto de vista:

"A partir de un momento la figura que construí fue la de entender que yo era autor no de un discurso sino de la gramática, una gramática que permite que el público digamos construya un discurso, yo lo que entonces creo es que las obras interactivas o al menos las que yo trato de crear, apuntan a construir una meta-máquina discursiva, una máquina que de alguna forma ponga el discurso de los otros en funcionamiento." (E. Causa, comunicación personal, 12 de noviembre de 2014).

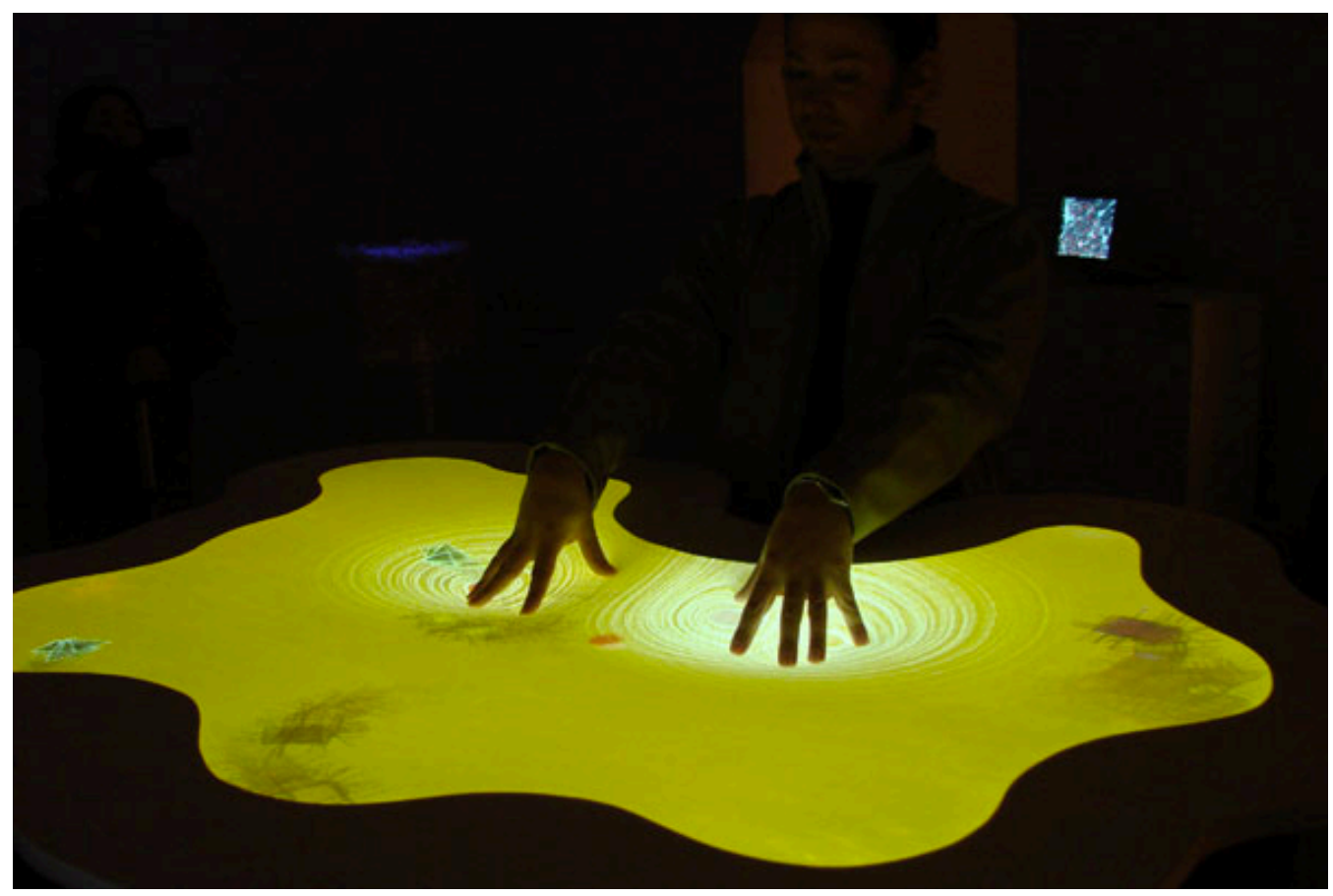

Ilustración 2 Generación de criaturas con vida artificial. Sensible, instalación interactiva. Grupo Biopus.

Como vector participante en la instalación, el público dibujó en su caracterización, roles no tradicionales que construyeron una nueva relación entre autor y público, roles que connotaron una obra permeable, abierta que invitó al público a acceder a ella.

La obra se propuso alcanzar un objetivo complejo, el cual hizo referencia a "La integración de fenómenos que evolucionan en el tiempo con otros de diferentes naturalezas, como la imagen, la música, la interactividad y los sistemas complejos...” (Biopus, 2007, pág. 15) de hecho la obra alcanzó varios logros como fueron: generar vínculos interactivos con el público que expandieron su rol a territorios nuevos, hacia una valoración estética por parte 
del participante de la formalización de fenómenos como el de la simulación de procesos de vida artificial y el de la composición musical.

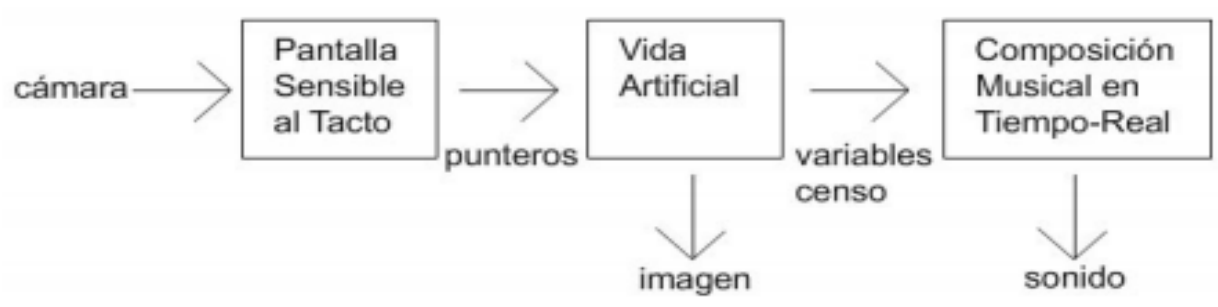

Esquema de los sistemas de Sensible

Ilustración 3 Esquema básico del sistema. Sensible, instalación interactiva. Grupo Biopus.

Sensible invitó a la participación para involucrarse y descubrir un universo complejo, en el cual se vivenciaran experiencias multisensoriales que apelaban directamente al sonido, al tacto y a la visión. Dicha invitación, le contactó con un sistema estructurado, en el cual se pusieron en juego tensiones a partir de simulaciones de vida artificial y creación de arreglos sonoros. La instalación de manera radical planteó al público abandonar la actitud distante, expectante o tradicional y le propuso interactuar utilizando sus manos a través de una diversidad de gestos que fueron previamente codificados y mediante los cuales se activaba todo el sistema. La instalación permitió la participación simultanea de los receptores, experiencia que posibilitó la relación entre sí del público.

La intención del grupo Biopus fue generar procesos de participación que alteraran el rol tradicional. En el sitio Web del grupo se encuentra el texto "Sensible: interactividad, vida artificial y música en tiempo-real" (Biopus, 2009, págs. 3-9) en el cual se describe en detalle los mecanismos de diseño de la interacción. A continuación, y extraídos del texto los siguientes aspectos referidos a los procesos de interacción y participación que validaron la afirmación:

1. "Sensible está conformado por 3 grandes sistemas: el de la pantalla sensible al tacto, el de simulación de vida artificial y el de composición musical en tiempo-real."

2. "El sistema de la pantalla sensible al tacto envía información al sistema de vida artificial respecto de los punteros y sus eventos. El sistema de vida artificial genera nuevas criaturas virtuales a partir de los gestos hechos en la pantalla, a su vez sostiene 
la simulación del ecosistema ya existente y determina variables de censo para pasar el sistema de composición en tiempo-real. Este último, utiliza los valores de estas variables para determinar los parámetros que gobiernan la composición musical en tiempo-real."

3. "La instalación Sensible posee en una mesa con una pantalla sensible al tacto que esta implementada con una tela elástica. Esta pantalla funciona mediante un sistema óptico que es capaz de detectar la sombra que se genera con los dedos al presionar la pantalla."

4. "Todo este proceso permite que los dedos sean vistos como punteros (muchos Mouse) y entonces se puede determinar que comportamiento ejecutar en función de cada evento de cada puntero."

5. “...el sistema está en constante tendencia al desequilibrio, pasando por momentos efímeros de equilibrio, y el objetivo de la interacción del público es sostener esos pequeños momentos de equilibrio y/o variar el desequilibrio."

6. "Por lo tanto, podemos decir que en Sensible se generaron, por un lado, un ecosistema virtual producto de la interacción de individuos con comportamientos propios, y por el otro lado, un sistema de composición musical conformado por módulos que añaden información por capas; y que, por último, se observaron ambos sistemas desde una perspectiva perceptiva para establecer criterios de analogía entre sus respectivas evoluciones."

La instalación Sensible logró en su diseño crear un sistema interactivo que trascendía el fenómeno de la reactividad, moldeaba el comportamiento y expandía el espacio instalativo a un conjunto complejo de interacciones hombre-máquina-sistema. Fue posible entonces abordar los roles del público a partir de las actuaciones, interacciones y comportamientos que este asumió en el encuentro con la instalación y se podría preguntar ¿se configuró como actor, interactor o usuario? 


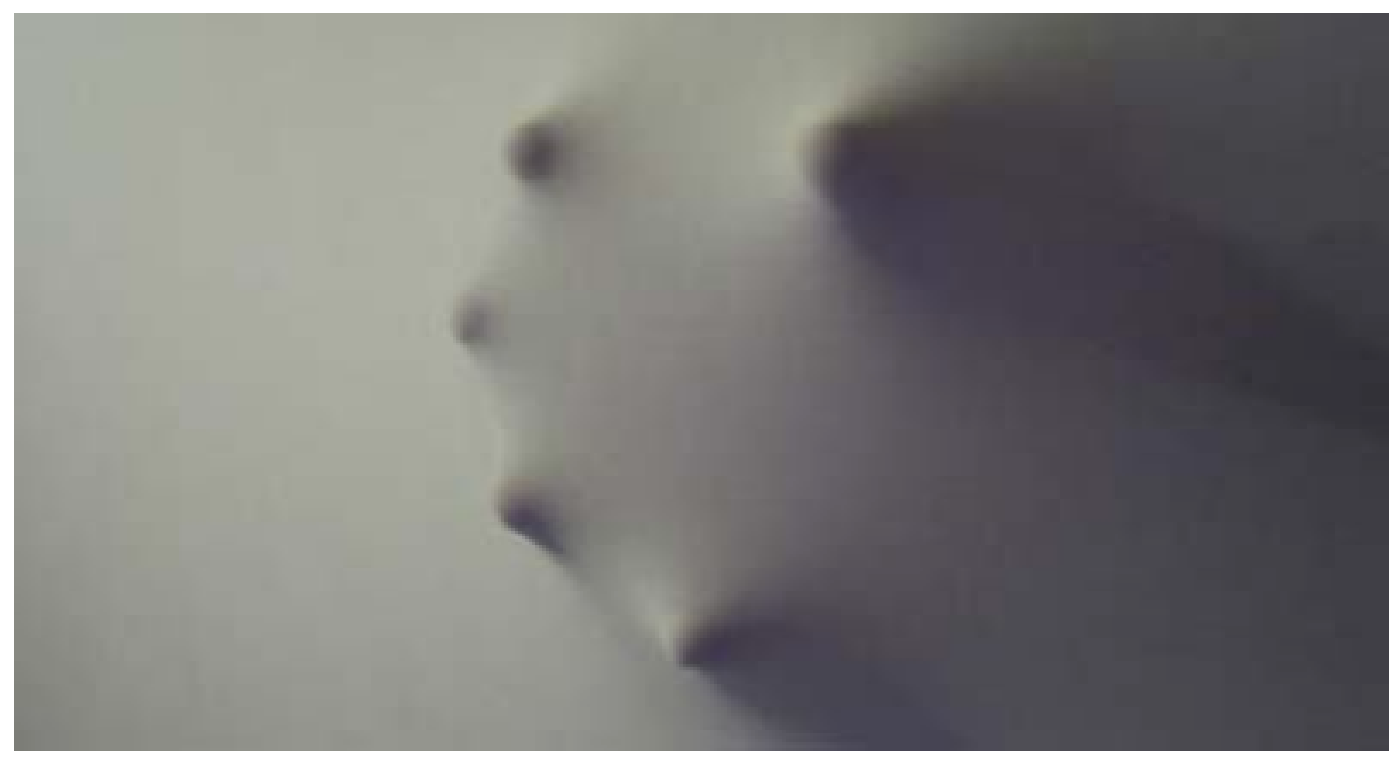

Ilustración 4 Sombras generadas por el contacto con la pantalla elástica. Sensible, instalación interactiva.

\section{Grupo Biopus.}

Para efectos de resolver la pregunta y aclarados los mecanismos de interacción y el perfilamiento que el artista hace de la instalación, se observó en el público la noción de interactor $^{11}$ en el rol que asumió. Por lo tanto, así se le denominará en adelante en la contrastación con las denominaciones de usuario y actor.

El diseño de la instalación previó respuestas paralelas a los gestos de la mano previamente codificados, los cuales se tradujeron en sonido y simulación de comportamientos de vida artificial en los organismos virtuales. Sin embargo las variables gestuales de la mano en el contacto directo con la membrana-interfaz, no necesariamente se sucedieron en un orden específico o jerárquico para desencadenar la activación de la instalación, mantener o no el equilibrio del sistema, o lograr el uso de la instalación; en el anterior sentido no se estableció una relación de usuario, como si se podrá evidenciar en obras como Turner siglo XXI o los Aparatos instalaciones en las cuales la nota de programa fue explícita y el usuario seguía estrictamente unas instrucciones dadas, con el fin de activar la instalación. En Sensible el interactor pudo a voluntad y en libertad acceder al contacto con

\footnotetext{
${ }^{11}$ Para efectos de la presente investigación se denomina al público de las instalaciones interactivas y robóticas interactor, cuando en el contacto con la obra se establezca una relación dialógica, activa y participativa bien sea a nivel físico o virtual, mediada por una interfaz. Interacción que se sucede, por el hecho mismo de ingresar en el espacio/tiempo instalativo y que a su vez denota interactuar de manera práctica con el sistema y la interfaz propuesta por el diseño de la obra, con el fin de activar los procesos potenciales que el artista ha diseñado para tal fin.
} 
la membrana interfaz. A partir de esta experiencia subjetiva accedió a la realidad interna de la instalación e interactuó desde sus propias lógicas estimulado por el universo que emerge de criaturas y sonidos. Si bien es cierto que el interactor se relacionaba corporalmente con la instalación a través del gesto y el movimiento, la noción de actor no se configuraba como es el caso de instalaciones como Tango Virus, en tanto que en Sensible hay una mediación de la membrana-interfaz a través de la cual se sucedía la activación del sistema.

En contraste a las nociones de usuario y actor, la noción de interactor se dibuja claramente. A continuación, la tipificación de dicho rol en la instalación Sensible a partir de lo observado, de la información del sitio Web de Biopus, de los papers referidos a Sensible y de la entrevista sostenida con Emiliano Causa integrante del grupo Biopus.

Al respecto en el sitio Web del grupo Biopus y tomado del texto Sensible: interactividad, vida artificial y música en tiempo-real, lo siguiente:

"El sistema de la pantalla sensible al tacto envía información al sistema de vida artificial respecto de los punteros y sus eventos. El sistema de vida artificial genera nuevas criaturas virtuales a partir de los gestos hechos en la pantalla, a su vez sostiene la simulación del ecosistema ya existente y determina variables de censo para pasar el sistema de composición en tiempo-real. Este último, utiliza los valores de estas variables para determinar los parámetros que gobiernan la composición musical en tiempo-real.” (Biopus, 2009, pág. 1)

Cuando el público intervino el sistema se transformó su papel, en tanto se tipificó un rol diferente al del público tradicional de la obra de arte. El contacto era real, físico, activaba la instalación, generaba equilibrios y desequilibrios en el sistema, propiciaba elaboraciones subjetivas y desencadenaba relaciones con la instalación y otros participantes, de ahí que se configuró o tipificó la noción planteada. El interactor que se configuró, no era ajeno a la voluntad expresa del artista y del diseño del sistema, por el contrario, trastocar la noción de público fue justamente uno de los objetivos de la instalación y por supuesto del artista, lo cual se materializó en la actuación del participante al activar la instalación; continuando con el texto citado se encuentra la siguiente referencia al respecto: “...el sistema está en constante tendencia al desequilibrio, pasando por momentos efímeros de equilibrio, y el objetivo de la interacción del público es sostener esos pequeños momentos de equilibrio y/o variar el desequilibrio.” (Biopus, 2009, pág. 7) 
La interacción que ocurre entre interactor-máquina es práctica y se sucede en un espacio-tiempo real. Al respecto Emiliano Causa refirió lo siguiente:

"Yo creo que de las obras que nosotros hemos hecho desde mi apreciación personal, la obra Sensible es una de las que mejor funciona, y esto es debido a que se produce una integridad de los medios que en las otras obras nos ha costado o no hemos logrado encontrar, me refiero a eso que yo le llamo el gesto interactivo, es ese lugar en donde el interactor no puede diferenciar entre sus acciones y lo que sucede, eso en Sensible pasa de esa manera. Una persona acciona sobre una pantalla y esto genera unos fenómenos físicos que el público no logra diferenciar (...) un pequeño estanque de la vida en el que yo opero con mis manos, nosotros nos dimos cuenta cuando lo hicimos, que la posibilidad de interactuar con las manos es más intuitiva, fluida y desprejuiciada que la de interactuar con el cuerpo o con la danza." (E. Causa, comunicación personal, 12 de noviembre de 2014).

El fenómeno de la inmersión por parte del interactor en su relación con Sensible se tipificó en la medida que este se sumergió en el estanque virtual que la instalación proponía. El ambiente generado, las atmósferas y la estética visual y sonora de la instalación generaron una realidad virtual que lo atrapó y a la vez le configuró. Las leyes que gobiernan el estanque virtual se emparentan con el mundo real. La superposición de dos realidades generó el fenómeno inmersivo de la obra. En referencia a dicho fenómeno Emiliano Causa comentó:

"Es una obra muy inmersiva técnicamente hablando. Me he preguntado desde que la hicimos cuales son los factores que la hacen una obra inmersiva, yo he visto al público interactuar con la obra 15 o 20 minutos de toda la franja etaria habida y por haber, niños de 10 años hasta gente de ochenta años. Hay algo muy impregnante en la imagen, esa especie de cuadro abstracto constante que se va creando, creo que está bastante lograda la relación entre lo que sucede a nivel visual y a nivel sonoro (...) Los procesos visuales y sonoros vinculados con los procesos de acción del público produce esa integridad que yo le llamo el gesto interactivo y en últimas genera el fenómeno inmersivo de la obra." (E. Causa, comunicación personal, 12 de noviembre de 2014).

En definitiva, Sensible instalación interactiva con un componente fuertemente inmersivo propuso en su momento, formas de interacción novedosas y complejas, las cuales 
generaron outputs del sistema igualmente novedosos, como fueron la posibilidad de componer algoritmos y relaciones de código, así como la expansión del rol del público hacia la noción de interactor. 


\subsubsection{Tango Virus - instalación interactiva - Grupo Biopus}

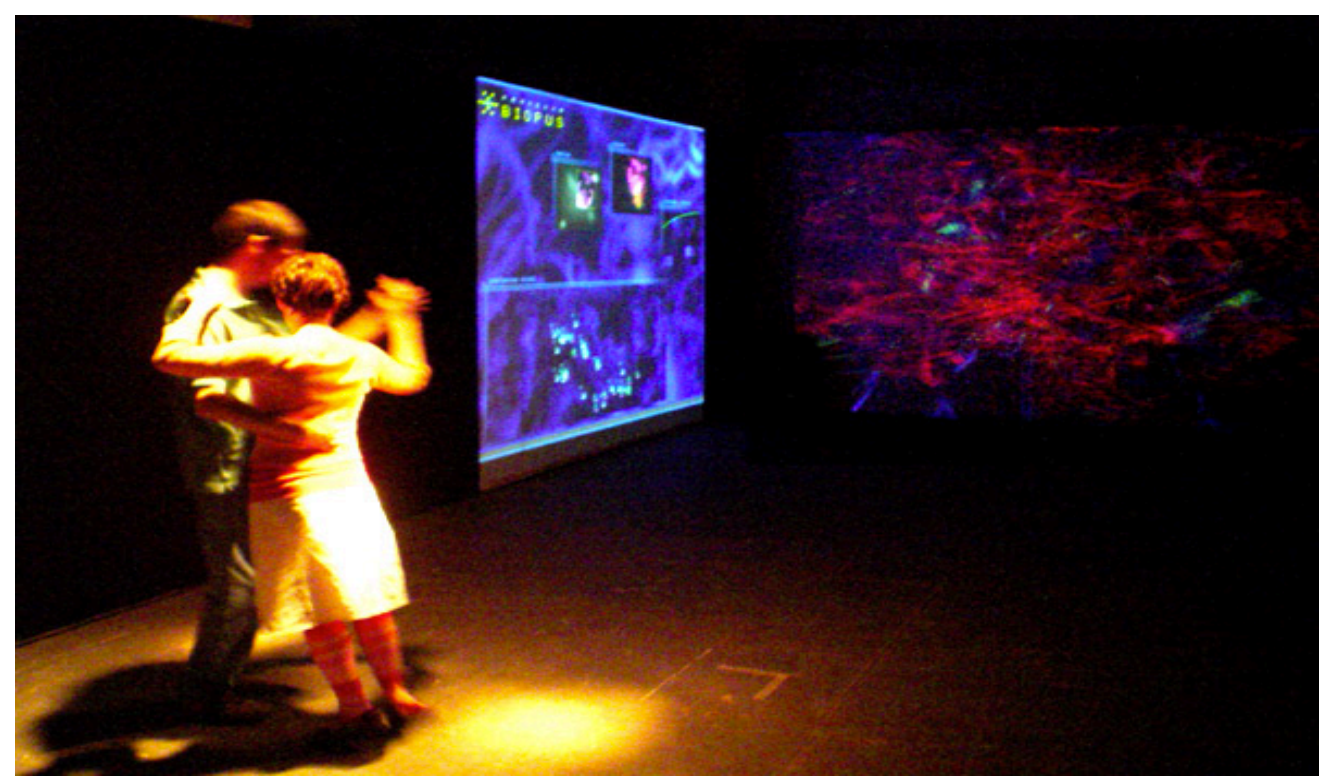

Ilustración 5 Participación del público en el espacio escénico de la instalación interactiva Tango Virus. Grupo Biopus.

A continuación, apartes del texto descriptivo de la instalación, los cuales al igual que las imágenes han sido tomadas del sitio $W e b$ del Grupo Biopus:

“Tango Virus es una instalación interactiva que permite al público modificar en tiempo-real un tema de tango (de Astor Piazzola) mediante un proceso viral. En la instalación, el público puede bailar el tema de tango que se está escuchando, pero dicho baile se transforma en un comportamiento viral que ataca al tema musical, haciendo que este varíe, quizás al punto de "fallecer".

(...) Se ingresa a un espacio a oscuras donde solo se ven dos proyecciones de video y un espacio iluminado en forma cenital. Una vez que el público decide bailar en el espacio iluminado, los movimientos del baile (que son captados por una cámara en el techo) generan un patrón visual en una de las proyecciones, dicho patrón se transforma en un virus que ataca al tema musical.

(...) La idea detrás de la instalación es la de explorar la participación del público en la creación artística a partir de un proceso destructivo (como es el proceso viral). $\mathrm{Si}$, como se dice, al tango lo llevamos en nuestra sangre, entonces ahora "nosotros infectaremos el cuerpo del tango". 
“(...) Por último, decidimos elegir temas del compositor Astor Piazzola como un homenaje a su música, que tanto disfrutamos, y a su espíritu de búsqueda y ruptura infatigable que han cambiado y dado nueva vida al tango." (Biopus, 2006)

Las búsquedas adelantadas por el Grupo Biopus para la producción de la presente instalación exploraron posibles conexiones entre:

1. El arte electrónico y los conceptos de vida artificial.

2. Las relaciones entre el movimiento y la captura del mismo por medio de tecnología electrónica,

3. Los desarrollos algorítmicos de codificación, la transformación de la información y sus posibles relaciones con otros fenómenos de naturaleza diferente.

Tango Virus instalación interactiva al preguntarse por los nexos entre arte y vida artificial abordó cuestiones referidas al rol del público y el vínculo que este establecía con la obra. Respecto de una posible participación en la creación de la obra por parte del público Emiliano Causa amplió:

"Siempre ha estado dando vueltas la discusión acerca de si el público es coautor de la obra, esa fue como la primera cuestión que se planteó. Yo sentía que si bien la interactividad habilitaba al espectador de alguna forma en el proceso creativo y en el desarrollo de la obra, decir que el público es coautor de la obra para mí no era del todo cierto y hasta impreciso en algún punto." (E. Causa, comunicación personal, 12 de noviembre de 2014).

Se vislumbró entonces un distanciamiento del rol tradicional tanto de autor como de público. La obra adquirió en virtud de su diseño y los presupuestos del artista, un carácter interactivo, lo cual obligó a la participación del público, quien pasó ahora a desempeñar un rol fundamental para la activación de la obra. En refuerzo de este presupuesto el artista sustentó: "Es decir, que el artista construye un conjunto de reglas, de entre las que el público puede elegir para desarrollar su propio discurso. Si bien el autor no puede saber qué es lo que el público hará, el público tampoco puede hacer cualquier cosa, dado que las reglas están determinadas por el artista." (Biopus, 2007, pág. 3)

La obra fue consecuencia de pesquisas en torno a la interactividad y en particular se interesó por las llamadas gramáticas generativas. Emiliano Causa refirió respecto al propósito de la obra lo siguiente: "Esta instalación intenta investigar la aplicación de un sistema 
adaptativo y evolutivo a la danza del tango, mediante un desarrollo de vida artificial que simula los procesos virales y el sistema inmune.” (Biopus, 2007, pág. 3)

A nivel del diseño, la instalación se estructuró en varios planos a saber:

- Captura del movimiento y generación de la huella coreográfica.

- Transformación de la traza coreográfica en un comportamiento viral.

- Proceso de distribución de los virus.

- Desarrollo de un sistema inmune.

- Procesamiento

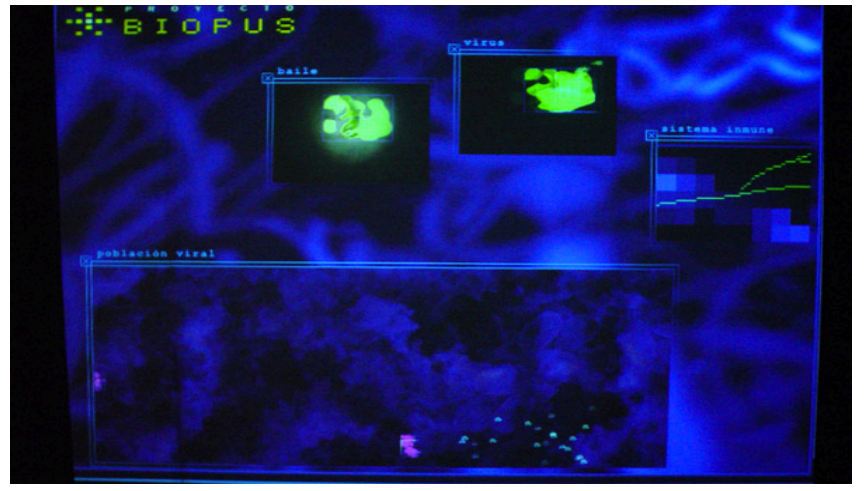

Ilustración 6 Nacimiento de un virus. Instalación interactiva Tango Virus. Grupo Biopus

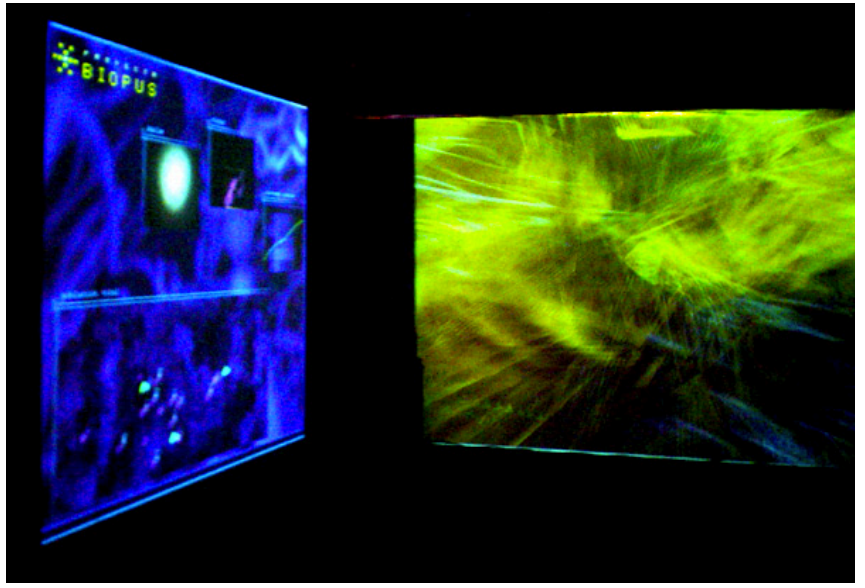

Ilustración 7 Imágenes de los virus (izquierda) y generadas por los virus (derecha)

A nivel conceptual Tango Virus propuso experiencias interactivas que cuestionaron la relación público-obra. De ahí que la instalación abordó la relación vida artificial-arte, y se preguntó por la cuestión estética que implica generar imagen y sonido en relación con otros fenómenos como el del baile, el movimiento y la vida artificial. Durante el proceso de diseño 
y formalización de la instalación se formularon una serie de interrogantes sobre la relación entre los virus y el arte:

“... ¿Cómo se captura el movimiento de la danza? ¿Qué momentos y gestos de la danza son captados? (...) ¿Cuáles elementos o características de la huella son tomados para determinar el comportamiento viral? ¿Cómo se desarrollan los virus y cuál es su ciclo de vida? (...) ¿De qué forma o con qué procedimientos se realiza la enfermedad del tema musical? ¿De qué forma el comportamiento viral determina esta enfermedad?" (Biopus, 2007, pág. 6)

Temáticamente en la instalación convergieron conceptos que aludían a algoritmos de simulación de vida artificial, generación de estéticas sonoras y visuales, equilibrio, enfermedad e inmunidad. Abarcó un horizonte amplio referido a la vida en relación con los comportamientos de seres virtuales, en este caso, virus y humanos involucrados en procesos a través del baile y la danza. Emiliano Causa al respecto dijo:

"El concepto central de la obra está en relación con captar el gesto corporal de las personas y transformarlos en una entidad viva que trasciende al gesto inicial que lo creó y poner esto en funcionamiento en un proceso relacionado con lo musical destructivo. Las ideas son la participación en la creación desde la destrucción, la creación de la cosa vida desde lo viral y lo gestual" (E. Causa, comunicación personal, 12 de noviembre de 2014).

Como se puede observar, la instalación ponderó el gesto corporal como el motivo central en torno al cual se desarrolló todo un sistema complejo que relacionó fenómenos aparentemente desconexos. De ahí que su diseño contempló entre otros propósitos técnicos los siguientes:

1. Propiciar formas interactivas en el público a partir del baile del tango.

2. Transformar los movimientos del baile del tango por parte del público en un virus informático.

3. Teniendo como soporte el movimiento, atacar con el virus creado un tema musical, en este caso un tango de Piazzola. Generar procesos de infección e inmunidad en el vínculo que se da entre el huésped y el virus.

4. Generar procesos de infección e inmunidad en el vínculo que se da entre el huésped y el virus. 


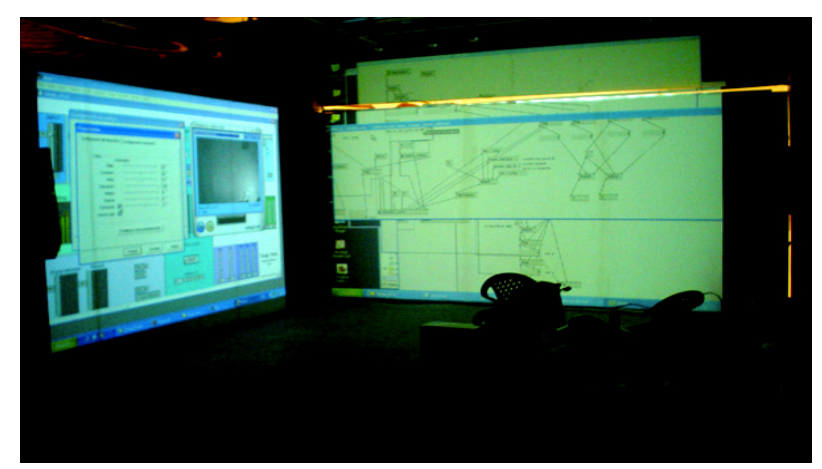

Ilustración 8 Vista de los sistemas de procesamiento. Instalación interactiva Tango Virus.

Grupo Biopus

En síntesis, Tango Virus pretendió como lo expresó Emiliano Causa en el siguiente texto:

"La idea detrás de esta instalación es la de explorar la participación del público en la creación artística a partir de un proceso destructivo (como es el proceso viral)(...) Por otro lado, la instalación busca perpetuar un hecho efímero, como es el baile, a partir de la creación de una entidad auto-organizativa, como es un virus, logrando que el baile trascienda como hecho a la persona y evolucione en forma independiente.(...) entonces este trabajo permite que la música y el baile ingresen en un diálogo propio, al margen del cuerpo, pero que a su vez permite dar al baile una existencia propia.” (Biopus, 2007, pág. 12)

La experiencia propuesta por la instalación moldeó la interacción en tanto le sumergió en una atmósfera participativa de sonido, imagen, baile y movimiento, en la cual se involucró el cuerpo y otras variables. La noción del público tradicional que se ubicaba en un espacio externo a lo que acontece se desdibujó completamente en el caso de Tango Virus.

A continuación, el análisis en torno a los roles que se tipificaron en esta instalación a partir del diseño propuesto por el artista.

Tango Virus propuso un dispositivo escénico que implicó que el participante se adentrara físicamente y experimentara la instalación. Mediante esta vivencia se configuró el rol de actor en el público; no en el sentido del ámbito teatral, en el cual se delimita el espacio de escenificación de la obra y el espacio designado para el público asistente, sino en el sentido de un performer que altere tal delimitación a través de una participación danzante que 
propicia la activación de la instalación, y el proceso destructivo viral que afecta la melodía del tango.

Respecto a esta noción de actor Silvina Valesini en su tesis de maestría afirmó:

" Cuando esa delimitación se altera, para posibilitar la interacción de un espectador que pueda llegar a modificar el flujo de la acción, este pierde su condición de tal para asumir el rol de actor, borrando de este modo el límite entre lo real y lo ficcional." (Valesini, 2014, pág. 57)

Desde la noción de actor ${ }^{12}$ establecida para la presente investigación, se puede observar cómo dicho rol se configuró en Tango Virus. Es de considerar como el diseño y funcionamiento de la interfaz de la instalación determina dicho rol. Al respecto Emiliano Causa en referencia a la interfaz de la instalación Tango Virus expresó:

"No podría decir que es el cuerpo, porque yo entiendo que la interfaz es lo que conecta el cuerpo con el fenómeno que es la obra, en este caso sería ese sistema de visión artificial que capta el movimiento, la mirada, el sensor a través de la cámara que es el medio que conecta las dos cosas.” (E. Causa, comunicación personal, 12 de noviembre de 2014).

En Tango Virus el gesto interactivo fue el resultado de la acción performática del que se movía en el espacio escénico de la instalación, bien fuera a través de los movimientos del baile como lo propuso la obra o por el simple desplazamiento en dicho espacio. La interfaz en Tango Virus no fue explícita, matérica o tangible para el participante, El sistema de visión artificial que captaba el movimiento y el sensor a través de la cámara era tácito e imperceptible para el bailarín. Fue la actuación en el espacio escénico de la instalación lo que activó el sistema de mirada artificial, los algoritmos y el proceso de activación del virus. Dicha relación de articulación y actuación que se estableció en el espacio instalativo configuró la noción y rol de actor en el sentido que en este estudio se ha tipificado.

${ }^{12}$ Para efectos de la presente investigación se denomina al público actor, cuando este, a través de una actuación performática -motivada por la misma instalación- establece un intercambio dialógico con el dispositivo instalativo, a través de la mediación de una interfaz no explícita, que es capaz de leer los movimientos, acciones o actuaciones del actor y modificar el estado de latencia potencial de la instalación, para de este modo, propiciar la activación del diseño del sistema propuesto por el artista. 
La obra claramente planteó un rol específico para el público en el caso que este quiera activarla, debió arriesgarse a abandonar su papel de simple asistente a un espectáculo. Ingresó en el espacio escénico de la instalación y actuó como bailarín al son del tango que se escuchaba, para así propiciar la cascada de eventos y fenómenos que se dispuso sucedieran a partir de su participación como actor en el proceso de producir huella coreográfica y por ende población viral. En el espacio creado para la danza era posible participar de forma simultanea varios actores de manera individual o en pareja e introducir nuevas huellas coreográficas la cuales gestaban más población viral, lo que equivalía a incidir directamente en el sistema.

Tango Virus, propuso como forma de interacción, la actuación en un espacio escénico a través de la danza. La interacción con la instalación por parte del actor en Tango Virus modificaba los algoritmos y los procesos de respuesta del sistema. Dicha actuación fue el origen de los outputs que el sistema generó, los cuales se materializaron mediante la visualización de: la población viral, las dinámicas de equilibrio y desequilibrio, la tolerancia de los virus al sistema inmune y los patrones de movimiento o huellas coreográficas.

De igual manera se generó la alteración del sonido en tiempo real del tango de Piazzola. La alteración de la secuencia sonora del tango a causa del virus, incidió directamente en la actuación del que baila, en tanto que el ritmo y la melodía característicos del tango se veían perturbados e incluso podrían llegar a ser destruirlos completamente, situación que igualmente ocasionaba que el desarrollo de los patrones de movimiento se vieran perturbados directamente y por consecuente la actuación del danzante en el espacio instalativo.

La obra se completó con la actuación del bailarín. La interacción del denominado actor fue imprescindible para que los procesos diseñados se activaran. En algún momento durante el tránsito que el actor hacía por el espacio escénico surgía la conciencia de que su actuación provocaba una influencia activa en la instalación. Se accedió así, al mundo subjetivo del que baila, en términos de las posibles intencionalidades que su danzar podría provocar en la instalación. La realidad exterior del que baila y la realidad interior de la obra se manifestaban en las poblaciones virales y las distorsiones sonoras; ambas realidades convivieron en el espacio escénico de la instalación y se sucedieron en tiempo real.

El tango de Piazzola invitaba a ingresarar y bailar en el espacio escénico diseñado para tal fin. Una vez la actuación se sucedía, los movimientos eran captados y entraban en 
contacto con el sistema. El reconocimiento de esta maniobra por parte del actor propició entonces el devenir intencional de sus de movimientos o trazas coreográficas. El comportamiento del que bailaba, aunque inesperado era previsible para el sistema, en tanto fuera movimiento.

La interfaz tácita de la obra y la actuación expresa del actor a través de la danza configuraran la expansión del rol tradicional hacia un espacio relacional. Al respecto dijo Emiliano Causa en la entrevista: “...la interfaz es ese espacio de articulación que en el caso de Tango Virus sería el cuerpo en interacción con el sistema de mirada artificial, los algoritmos y el proceso de activación del virus." (E. Causa, comunicación personal, 12 de noviembre de 2014).

El fenómeno de la inmersión en esta obra estuvo mediado por la participación, a través del bailar y experienciar la obra desde un lugar nuevo: el del actor, quien actuaba al compás del tango que se escuchaba y que era afectado por el devenir mismo sus movimientos.

Tango Virus fue una instalación interactiva que trajo novedades a la escena del arte electrónico argentino en la medida que investigó y desarrolló estrategias de captación de movimiento en relación con conceptos de vida artificial y propuso estéticas novedosas de representación de los fenómenos citados, en un espacio escénico en el cual confluyeron, la ciencia, la tecnología y el arte.

Esta obra propició en el escenario local del arte electrónico en Buenos Aires, el advenimiento de nuevos roles en el público tradicional que visitaba los espacios de exhibición y distribución por aquel entonces. Por medio de la actuación se facetó el rol de actor, y a través del movimiento que devenia del baile el gesto interactivo. 


\subsubsection{Libros de arena - instalación Interactiva - Mariano Sardón}

"Libros de arena. Es una instalación interactiva que relaciona el movimiento de las manos en la arena con códigos HTML de hipertextos extraídos de la Web en los que hay escritos textos de Jorge Luis Borges. La instalación consta de 2 cubos de vidrio de $85 \mathrm{~cm}$. de lado llenos de arena, que al tocarla con las manos surgen códigos HTML, que copian el movimiento de las manos. El texto se mueve como un fluido y desaparece posteriormente. Ambos cubos constituyen dos interfaces que involucran un juego táctil siendo la arena el soporte para el despliegue de los textos. La arena es la sustancia de fondo sobre la que se despliegan los hipertextos que constituyen la memoria vasta de la $W e b$. Esta es una red dinámica e inmensa que conecta personas en diferentes puntos del planeta. Dicha red es pensada como un texto diseminado en el tiempo y el espacio, el más grande nunca escrito, el más complejo e impredecible. Las propuestas acotan en la geometría de un cubo lo que ocurre como infinito e inaprensible de un texto que las manos capturan por un instante solo un puñado. La información, como el texto y la arena, indistinguibles e innumerables, toman su propia forma definida en virtud del gesto abarcador y categorizador de las manos en ese preciso instante. La construcción del espacio por medio de la luz, los colores y las texturas fue fundamental para definir la propuesta. La sala en penumbras creaba una atmósfera de irrealidad, algo apartado del mundo. Esta característica resultaba paradojal ya que utilizaba una red de comunicaciones globales para establecer un ámbito íntimo. En esta instalación se estructuran arquitecturas de hardware y software que operan sobre una abstracción matemática, sustancia propia en la que se basa la información digital, configurando sucesivos puentes de relación entre lenguajes. Al no haber control sobre la construcción de los códigos que revela el espectador con sus gestos y movimientos, se quita el control comúnmente asociado a la idea de interactividad en las interfaces de las computadoras, para pasar a un juego gestual de materialización contingente del texto esparcido en la red.” (Sardón, 2008) 


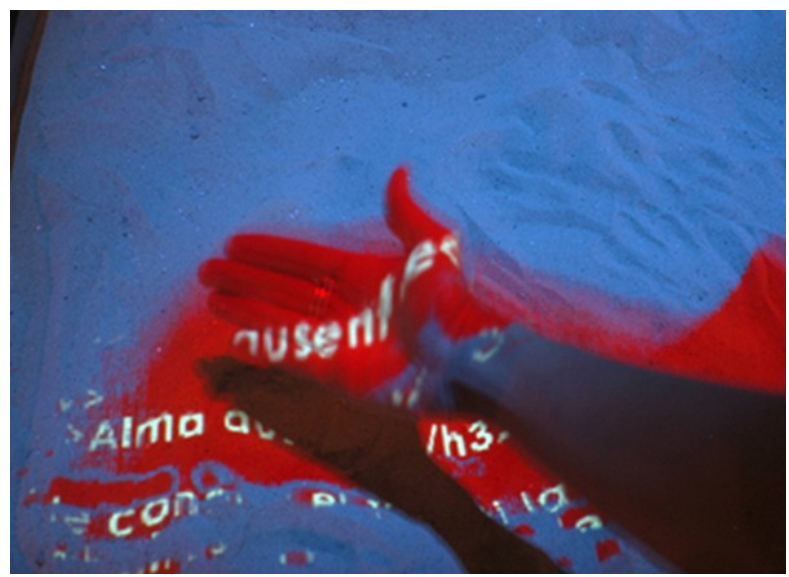

Ilustración 9. Detalle instalación interactiva Libros de arena. Mariano Sardón.

La obra puso en juego desarrollos de programación adaptados a las plataformas disponibles en la escena local de Buenos Aires de principios del siglo XXI. El diseño de la instalación investigó en torno a la captura de imágenes desde una cámara. Estas imágenes fueron procesadas por un software específico con el fin de analizar que movimientos aparecerían en el campo de la imagen. La información relevante extraída era mapeada sobre códigos HTML bajados de Internet, los cuales se almacenaban en una base de datos mediante un programa parser.

Libros de arena instalación interactiva fue consecuencia de indagaciones de tipo experimental llevados a cabo por el artista. La relación entre ciencia, tecnología y arte en la presente obra exploró las posibilidades expresivas y conceptuales en torno a la participación e interacción. Mariano Sardón trabajó en el proyecto a partir del año 2003, después de terminar una residencia en los Estados Unidos, estadía en la cual desarrolló procesos de indagación en torno a modelos de interacción usados en la física con el propósito de expandirlos a proyectos de arte.

Con relación a los procesos de indagación y búsqueda que sustentaron la obra, Mariano Sardón los describió así:

"Ese trabajo en realidad lo empecé a hacer en la UCLA en Los Ángeles, en el 2001, todo lo que tuvo que ver con parsecs y búsqueda de información. En ese entonces en esa universidad había una red que era como de un mega, que para la época era rápido, buscar en Internet era una cosa que se podía hacer con cierta liviandad, esa búsqueda era independiente de Libros de arena, después cuando armo Libros de arena y uso ese desarrollo, primero lo conectamos a la red cuando lo montamos en el 
Museo de Arte Moderno, pero bueno se caía se colgaba a cada rato la red, los tiempos eran otros, por lo tanto, decido guardar todo en una base de datos." (M. Sardón, comunicación personal, 12 de septiembre de 2014).

Libros de arena, hizo su aparición en el año 2004 en el espacio museístico de Buenos Aires. Esta instalación generó ciertas rupturas. Conceptualmente trabajó aspectos de la interactividad, del espacio museístico, de la data almacenada en la red y de las posibilidades del azar en la relación que se establece entre el espectador y el sistema propuesto por la instalación.

El arte electrónico y en particular las instalaciones interactivas generaron aproximaciones al concepto de autor desde otras perspectivas, algo que posibilitó la reflexión acerca del desplazamiento o no del concepto de autoría. En el escenario del arte electrónico en Buenos Aires de principios de siglo XXI la noción de autoría era parte de las discusiones académicas. Al respecto Mariano Sardón comentó:

"Quizás yo debería decir ciertas cosas con respecto del autor, pero lo cierto es que en ese entonces se hablaba mucho de la dilución del autor en el sentido clásico, me acuerdo de esas cosas y creo que en algún punto eran ciertas dado que el rol del espectador cumplía una función fundamental en la hechura misma material de la obra, entonces en ese momento, el darle al espectador posibilidades de que pudiera manipular la obra, dejarlo resolver cosas que probablemente uno no tenía apriori tan resueltas y sobre las cuales no tenía tanta potestad sobre la forma y uno sentía que ciertamente se había corrido de cierta noción de autor." (M. Sardón, comunicación personal, 12 de septiembre de 2014).

A diferencia de la obra de Marina Zerbarini en la cual se visibiliza el papel de usuario, Libros de arena propone una franja distinta de participación. Mariano Sardón afirmó con relación a la información disponible en el espacio instalativo lo siguiente: "Si, había una nota que contaba un poco el sentido de ese trabajo, no tanto como funcionaba. Hablaba sobre la reflexión acerca de la memoria, sobre Borges, sobre lo incontrolable y sobre lo parcial." (M. Sardón, comunicación personal, 12 de septiembre de 2014). Es decir, la obra esperaba que el público se adentrara en la vivencia interactiva desde una noción diferente y abandonara su rol tradicional. 
Efectivamente, esta obra se cuestionó por las relaciones entre el público y la instalación, se interpeló así misma por los grados de libertad que el público tuvo frente a su interacción con la instalación, así como por la aleatoriedad de la experiencia. Continuó el artista refiriéndose al papel del público en cuanto a si completa o no la obra así:

“...en la obra hay un cubo, hay arena y una serie de cosas que pasan con la red, el Internet y un montón de software que las decidí yo, en todo caso si se podía pensar en ciertos grados de libertad que se daba al espectador y después había cosas que efectivamente los espectadores hacían mucho más allá de lo que uno podía compensar ya en el devenir mismo del uso del trabajo.” (M. Sardón, comunicación personal, 12 de septiembre de 2014).

La obra se caracterizó por una estética minimalista representada por la geometría cubica de los recipientes que contenían la arena y las imágenes efímeras de los textos de la literatura borgiana extraídos de la $\mathrm{Web}$ mediante procesos algorítmicos. Los cubos son un espacio finito, que encierra un infinito de información contenido en la arena. Los cubos de arena operaron como interfaces que proponían un juego táctil para involucrar al participante.

Más allá de la estética minimalista del espacio y los objetos, la obra exploró temáticamente la conocida obra Libros de arena de Borges, de la cual tomó su título. Dicho texto plantea la paradoja de un libro sin comienzo ni final, encerrado en un bucle infinito que no conduce sino al generarse una y otra vez. En el anterior sentido la instalación planteó la misma metáfora que el libro, al conceptualizar la Red como un arreglo infinito de hipertextos que conducían a infinitos textos y los cuales nunca se repetían, dado que la Red se renueva a cada instante. La Red a su vez paradójicamente devela fragmentos de su contenido total, y este contenido se manifiestan solo a través del movimiento de las manos del usuario que busca incansable por el infinito espacio virtual.

La obra exploró la relación del hombre aislado y solitario, enfrente del mundo que le rodeaba. Hizo uso de recursos tales como: la luz, la textura, y el color. Creó un espacio en penumbras, con una iluminación tenue sobre los cubos de arena, creando una atmosfera artificial que invitó a participar en la paradoja de un espacio aislado y solitario 
que le conectaba con un mundo global de comunicaciones, en torno a una metáfora específica: la literatura virtualizada y fragmentada de Jorge Luis Borges.

Con respecto a la estructura de la obra y los aspectos técnicos de la instalación13, estos fueron referenciados de la siguiente manera:

1. La instalación requiere un cuarto oscuro y los ordenadores deben estar ocultos en un cuarto diferente y cercano. Uno o más cubos llenos de arena estarán instalados en el espacio dependiendo de las dimensiones del mismo.

2. Cámara CCD de color y un proyector por cubo están suspendidos desde el cielorraso. La cámara registra lo que sucede encima de la arena depositada en el cubo y el proyector proyecta imágenes de texto sobre la arena. Ver figura 2

3. La cámara captura los movimientos de las manos sobre la arena, los cuales son analizados y procesados en tiempo real por un software especialmente desarrollado para la instalación por Laurence Bender.

4. El software extrae el movimiento que se sucede en el campo de la imagen previamente definido. Cada imagen del movimiento de las manos recuperado es mapeada en código HTML y almacenado en una base de datos.

${ }^{13}$ http://www.mat.ucsb.edu/acmmm06/arts/pdfs/booksofsand.pdf.

"The installation needs a darkened room and the computers have to be hidden or in a different chamber near to the installation room. One or more glass buckets full of sand are settled in space. It depends on space dimensions.

1. $1 \mathrm{CCD}$ color camera and one data projector per bucket are hung from the ceiling room. The camera takes the images from above the sand cube and the projector projects de text images on the sand. See figure 2.

2. The 1CCD camera captures images of the hands in the sand, which are analysed by a real time image processing software developed specifically for the installation by Laurence Bender.

3. The software extracts what moves or appears in the image field. Once the significant data of the movement of hands in each image is retrieved, the information is mapped on HTML codes kept in a database.

4. The texts stored are HTML codes retrieved from the Web by aparser program. This software was initially programmed in Lingo for an easy image processing later in Macromedia Director. New versions are developed using CGI Perl programming.

5. Such parser programs, can identify information or find objects within the site's codes, analyse them and extract the information to place it in a database.

6. Finally, the processed information from the camera and mapped to the HTML codes are projected on the sand, interacting with the movement of the hands." Traducción H. Miranda 
5. El texto almacenado son códigos HTML recuperados mediante un programa parcer, dicho software fue inicialmente programado en Lingo para luego ser programado en Macromedia Director dadas sus facilidades. Nuevas versiones fueron desarrolladas usando CGI Perl programming. Tales parser programs, pueden identificar o encontrar objetos, analizarlos y extraer la información para almacenarla en la base de datos.

6. Finalmente, la información procesada desde la cámara y mapeada desde los códigos HTLM son proyectadas sobre la arena interactuando con el movimiento de las manos.

Los procesos planteados en el párrafo anterior, construyeron el escenario en el cual el el interactuar ocupó un lugar fundamental para la activación del sistema diseñado. A través de la participación e interacción con la instalación se desdibujó el rol tradicional y se facetó nuevas formas de relación con la obra. Al respecto Mariano Sardón planteó con relación al público: "La desarrolla, le da temporalidad, le da formalidad y tiene un rol participativo, yo creo que es más radical el cambio para el espectador que para el autor.” (M. Sardón, comunicación personal, 12 de septiembre de 2014).

Continuando con esta línea de análisis, la participación activa se tornó una experiencia en la cual se establecía una relación dialógica mediada por una interfaz que en el caso de Libros de arena como lo dijo el autor de la obra son los cubos de arena14. Dicha relación fue activa y se dio tanto a nivel físico como virtual. La interacción ocurría en el momento mismo del ingreso en el espacio/tiempo instalativo. La paradoja del azar se presentó en tanto el diseño de la instalación se activaría, si alguien interrumpía cierto ángulo de visión del sensor. De lo contrario no se activará y permanecerá como una obra quieta y muda, al respecto el artista dijo: "A mí me interesaba particularmente, el proceso de descubrimiento por parte del espectador; el trabajo en realidad tenía una apuesta, cuando vos te acercabas al cubo, había una posición en particular que disparaba sola la instalación porque en realidad el sensor veía tu cabeza.” (M. Sardón, comunicación personal, 12 de septiembre de 2014).

\footnotetext{
${ }^{14}$ The buckets constitute two interfaces that involve a tactile game; the sand is the background substance for the unfolding of the hypertexts of which the Web immense dynamical memory is constituted. M.Sardón.

http://www.mat.ucsb.edu/acmmm06/arts/pdfs/booksofsand.pdf. Traducción H. Miranda
} 
La intencionalidad del artista quedó manifiesta. Una vez la instalación fue activada, se generaron una serie de actuaciones y relaciones que expandieron el rol hacia la noción de interactor, teniendo para ello como base la acepción que de dicha palabra se precisó en el capítulo cuatro y la cual se cita a pie de página.15 Por lo tanto el interactor se involucró con la obra. El juego táctil con la arena lo remitió a planos subjetivos. La lúdica entre manos, arena y movimiento activaba cascadas de imágenes las cuales se proyectaban sobre el espacio instalativo y correspondían a fragmentos de textos de Borges extraídos de la Red. El movimiento aleatorio de las manos del interactor en su relación con la arena, era censado y transformado en imágenes aleatorias, procedentes de una base de datos o de la red directamente. Al respecto Mariano Sardón dijo:

"La obra está conformada por dos cubos transparentes colmados de arena. A medida que el público la manipula, una cámara captura los movimientos de las manos y estos datos son asociados a hipertextos extraídos de la $\mathrm{Web}$ que contienen textos de Jorge Luis Borges. En consecuencia, los textos son proyectados sobre la arena y paulatinamente son transformados según la interacción de los participantes." (Adler, 2015)

La noción de interactor se configuró en esta obra en la medida que:

1. Se estableció una relación dialógica con la obra.

2. Dicha relación fue activa, participativa y dialogante.

3. El contacto se produjo a nivel físico a través del gesto de las manos y en el contacto con la arena que funcionaba como interfaz matérica y explícita.

4. La activación del sistema se sucedió a causa de la participación y estuvo mediada por la interfaz y el movimiento.

15 "Para efectos de la presente investigación se denomina al público de las instalaciones interactivas y robóticas interactor, cuando en el contacto con la obra se establezca una relación dialógica, activa y participativa bien sea a nivel físico o virtual, mediada por una interfaz explícita. Interacción que se sucede, por el hecho mismo de ingresar en el espacio/tiempo instalativo y que a su vez denota interactuar de manera práctica con el sistema y la interfaz propuesta por el diseño de la obra, con el fin de activar los procesos potenciales que el artista ha diseñado para tal fin." 
1. La aleatoriedad textual de la obra generaba la metáfora del fragmento. Metáfora que cautivaba al interactor y lo hacía desempeñar gestos y acciones que pretendían provocar la activación, lectura y captura de los textos.

Libros de arena fue una obra que para el tiempo en que fue exhibida por primera vez en Buenos Aires (2003), trajo a la escena del arte electrónico de la ciudad una propuesta de interacción novedosa, en tanto que, cuestionó la interacción misma y a la ves el rol tradicional del público. Mariano Sardón, argumentó sobre esta variable interactiva:

"Yo lo que creo que se reanima todo el tiempo es la interacción, el vínculo en sí mismo. La interacción son todas esas sustancias puestas de manifiesto, no solo es el código. Esa apuesta así, como esta en escena pone en relación cada vez y todo el tiempo esos elementos que calan tan adentro que producen ese gancho, y terminan gustando, no hay mucho que pensar para vivirla. (...) lo que quería compartir era la experiencia en sí, el modo de vincularse, con el frio del agua, el movimiento, como se vuelve a hundir el agua en la arena.” (M. Sardón, comunicación personal, 12 de septiembre de 2014).

La instalación interactiva del artista Mariano Sardón más allá de transitar por los conceptos de interacción, fue novedosa también en tanto introdujo la programación y el código como herramientas al servicio del proceso creativo. El artista valida dicha afirmación cuando comentó:

"Al margen mucha gente trabaja estas cosas desde la academia como la Universidad de Buenos Aires sin embargo a nivel artístico era novedoso aquí. Por supuesto tenías que meter más de lleno que ahora, había que programar, los programas eran más limitados, la capacidad igualmente. Fue novedoso en un determinado contexto, el valor que yo le hallo es que la obra en sí a nivel pedagógico por todo lo que tuvo que desarrollarse acá en la época de la pos crisis, con lo que Laurent desarrolló para el proceso de imágenes con Windows hecho por él y por mí, sirvió como columna vertebral para lo que era la columna vertebral de lo que era la carrera de artes electrónicas de la Universidad Tres de Febrero, desde ahí pudimos estructurar varias materias que trabajaban con la imagen digital y electrónica, que estaban más ligadas al video y de pronto introducimos en la universidad enseñar estas cosas como 
matemática, programación un poco más dura.” (M. Sardón, comunicación personal, 12 de septiembre de 2014).

En síntesis, Libros de arena logró conectar los avances tecnológicos, la programación, la metáfora de la Red y la virtualidad, el acervo literario de Borges y la paradoja de lo finito y lo infinito en el espacio creativo de la instalación y la interactividad, para interpelar tanto al espacio museístico de la ciudad como el del público y propiciar la expansión de la frontera de la actuación tradicional del público hacia el rol de interactor. Para finalizar Mariano Sardón refiriéndose al impacto de la instalación dijo: "Mirá, es difícil, en ese momento en que surge la obra en realidad a nivel tecnológico todo existía, en el mundo se hacía; acá en Argentina no había tanto de eso, menos en los espacios artísticos convencionales. (...) Cuando apareció Libros de arena muchos chicos se motivaron a entrar en el campo.” (M. Sardón, comunicación personal, 12 de septiembre de 2014). 


\subsubsection{Efecto Mariposa - instalación Interactiva - Patricio Gonzalez, Vivo}

“El sábado 4 de junio de 2011 el volcán Puyehue, luego de varias décadas de inactividad, expulsó junto con material piroplástico una columna de cenizas de 10 kilómetros de alto y cinco de ancho. Esto provocó un desastre natural con fuertes repercusiones ambientales y financieras en la región. Al mismo tiempo, y de forma paradójica, la ceniza que hoy causa la muerte de miles de seres vivos, garantiza la fertilidad de la región para años venideros. Esa misma ceniza es la materia prima de esta obra. Efecto Mariposa es una instalación interactiva que brinda la posibilidad de explorar cómo la destrucción y la creación que se combinan en una danza fractal e infinita, poniendo de manifiesto la capacidad de la vida para abrirse camino ante la adversidad. Esto se realiza mediante la simulación de un ecosistema sobre la superficie de un conjunto de ceniza volcánica en tiempo real. El interactor podrá modificar con sus manos tanto la "topología" de la misma como la "atmósfera" de público mundo virtual desatando toda clase de cambios climáticos y topográficos que influyen directamente sobre las condiciones de la vida. La invitación es a alternar la percepción entre lo micro y lo macro para descubrir la complejidad y la riqueza del mundo que nos rodea, así como también a percatarnos de nuestra participación y responsabilidad en público todo.” (González P. , 2012)

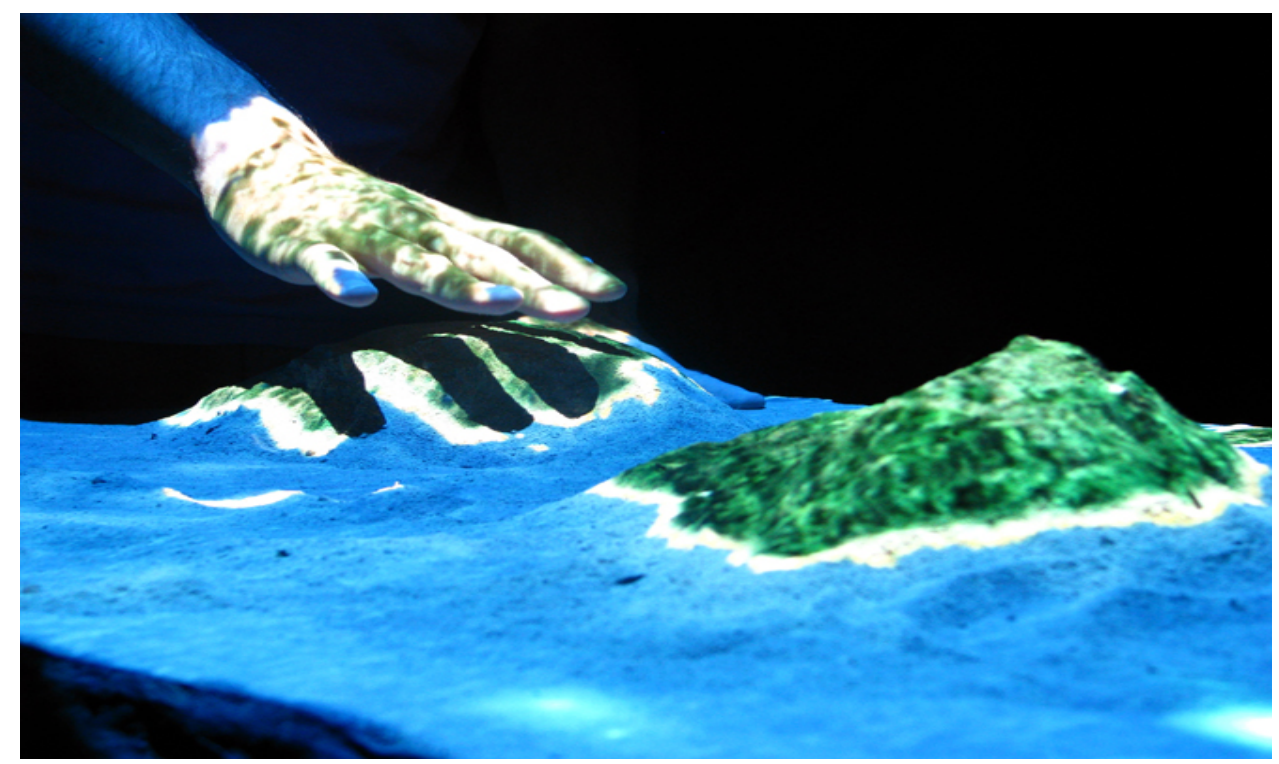

Ilustración 10. Efecto mariposa - Instalación interactiva-Patricio Gonzalez. 
La instalación tuvo por objetivo el diseño de una experiencia que propiciara un espacio de interacción y reflexión. Por otra parte, las posibilidades tecnológicas se convirtieron en una oportunidad para que el artista indagara acerca del vínculo entre la obra y el público. Al respecto Patricio Gonzalez en la entrevista manifestó:

"A partir de ahí, surge la intriga de cómo sería hacer o proponer un vínculo o una obra totalmente digital que pudiera mediar con esa ansiedad (del consumidor respecto a la tecnología). En ese mismo año apareció la cámara kinect y viendo las posibilidades que ofrece me surge la idea de trabajar con arena. Yo había trabajado con arena en arte terapia, sabia de sus propiedades nobles para recibir impactos, entonces hice un par de experimentos y me surge la idea de generar una simulación que sea súper invitante..." (P. Gonzalez, comunicación personal, 12 de agosto de 2014).

Temáticamente, la obra se centró en la simulación en tiempo real de un ecosistema complejo. En la creación de un mundo virtual, donde el público modificara con su intervención la topología de la ceniza volcánica o la atmósfera del ambiente. Así fue como el artista estableció un puente perceptivo entre lo macro y lo micro. Dio cuenta de la complejidad del fenómeno propuesto y del grado o nivel de responsabilidad del hombre frente al delicado equilibrio de la naturaleza entendida como un todo.

Instalación interactiva, que devino de un proceso de búsqueda en torno a variables que versaron sobre aspectos como: la realidad aumentada, los algoritmos de simulación de crecimiento de bacterias, las alteraciones que por acción del hombre se suceden en la naturaleza, el comportamiento interactivo en la relación la tecnología, los Open Frameworks, y las interfaces naturales. La instalación fue un proyecto investigativo que se gestó y financió desde el Centro Cultural de España en Buenos Aires - CCEBA - producción que se desarrolló de manera colaborativa y con la participación de un grupo interdisciplinario en el marco del laboratorio de producción del MediaLab durante el año 2011.

La obra Efecto mariposa, instalación interactiva, fue un desarrollo que se cuestionó él como incorporar la participación y a la vez él como expandirla. De ahí, que su autor diseñó una experiencia en la cual el componente relacional fuera un puente para la producción de sentido o para propiciar vínculos con el otro. 
Consideró Patricio Gonzales, que el papel colaborativo del receptor en relación con la producción de la obra varió mucho. Al respecto dijo: "Creo que hoy por hoy el concepto de autoría cambio muchísimo, el Internet y la posibilidad a través de él no solo de compartir contenidos sino también herramientas, sobre todo cuando trabajás con cuestiones digitales." Dejó entrever que el fenómeno colaborativo en la Red y la consolidación de comunidades de programadores, artistas y desarrolladores, así como la conexión entre la obra y la Internet, afectó de manera significativa los procesos de producción y creación de la instalación.” (P. Gonzalez, comunicación personal, 12 de agosto de 2014).

Afirmó en la entrevista Patricio Gonzales respecto al trabajo colaborativo en la Red:

"En mi caso, mi background es en sicología, mucho de las cosas que yo aprendí y utilicé al principio provenían de otras personas. Herramientas como Proccesing de código abierto y la comunidad Open Frameworks conformada por una comunidad de autores, creadores y artistas a la cual pertenezco por fortuna y la cual está desarrollando sus propias herramientas. La comunidad está conformada por personas de campos muy diversos de ahí la necesidad de colaboración entre todos en los procesos de construcción de las herramientas y los aspectos técnicos." (P. Gonzalez, comunicación personal, 12 de agosto de 2014).

Se pudo observar el amplio espacio interdisciplinario en que se enmarcó la obra en cuestión. El concepto o la metodología de trabajo colaborativo amplió las perspectivas creativas y permitió el cruce interdisciplinar. La obra trascendió la noción de reactividad y se instaló en el espacio de la interactividad. Al respecto, el artista afirmó: "Creo hay una diferencia entre arte interactivo y arte reactivo. En el arte interactivo uno se imagina un espectador y el cómo incorporarlo, es un asunto relacional en el cual se generan vínculos, es una forma de diseñar una experiencia en la cual estás teniendo muy en cuenta a la otra persona." ..." (P. Gonzalez, comunicación personal, 12 de agosto de 2014).

En Efecto mariposa la mediación de un comentario escrito al margen de la instalación no se propició. Patricio Gonzales declaró al respecto: "En mi obra Efecto Mariposa no había ningún tipo de comentario al margen de la exhibición, solo estaba el rotulo del nombre de la obra. Yo prefiero las obras que implican la intuición del espectador. Para mi es preferible que 
no haya un manual junto a la obra." (P. Gonzalez, comunicación personal, 12 de agosto de 2014).

La obra se estructuró a nivel técnico en diversos niveles, a continuación, se detallan los más relevantes:

1. Se desarrolló en código openFrameworks y algunos shader GLS personalizados.

2. Utilizó drivers ofxOpenNI para el control de la cámara Kinect, lo que permitió el escaneo en tiempo real de la superficie de las cenizas volcánicas, para crear un mapeo de profundidad de la topología escaneada.

3. La información tomada a través del proceso de escaneo se transformó en imagen simulada y se proyectó sobre la superficie de la ceniza volcánica.

El sistema propuesto propició el dialogo. Situación que facilitó el advenimiento de un rol diferente frente a la obra. Lo anterior, implicó que la participación o interacción a través de una interfaz explícita provocara la activación de todo el sistema. De esta forma, el interactor modificó la superficie de las cenizas volcánicas a partir del gesto manual, bien fuera de manera directa por el contacto con las cenizas volcánicas o indirecta sobre el aire circundante entre las cenizas y la cámara de captación de movimiento. El gesto interactivo modificó las condiciones de la instalación, produciendo cambios que se reflejaron en la manera como el sistema, en tiempo real, produjo nuevos ecosistemas y relaciones entre las diferentes capas que conformaron la instalación, a semejanza de como el hombre lo hace con su medio ambiente en una escala diferente.

El proyecto se estructuró en cuatro componentes a saber:

1. La interfaz, materializada a través de las cenizas provenientes de la erupción del volcán. Las cuales conforman o simulan el terreno del ecosistema.

2. La cámara Kinect de captura del movimiento, la cual hace el seguimiento del gesto y el registro de las formas resultantes.

3. Un computador que procesa la información recolectada, la codifica y la transforma en información visual.

4. Un proyector que transmite las imágenes del ecosistema sobre las cenizas volcánicas.

Para la producción de la simulación del ecosistema el artista superpuso 8 capas diferentes. Cada una de las capas superpuestas simuló un elemento del ecosistema. Tres correspondieron a los elementos topológicos: profundidad, forma y ruido. Los 
otros cinco componentes correspondieron a los componentes climáticos: geósfera, hidrósfera, biósfera, y atmósfera. El producto final fue una instalación interactiva, en la cual, el interactor fue capaz de simular cualquier tipo de clima y realidad topográfica. Al respecto, Patricio Gonzalez hizo la siguiente afirmación: “"Efecto mariposa es una instalación interactiva que ofrece la oportunidad de explorar la destrucción y la creación, que se combinan en una danza infinita fractal, lo que demuestra la capacidad de la vida para cortar a través de la cara de la adversidad." (P. Gonzalez, comunicación personal, 12 de agosto de 2014).

Las siguientes imágenes referidas al diseño de la instalación proviene de capturas de video en la $\mathrm{Web}^{16}$ :

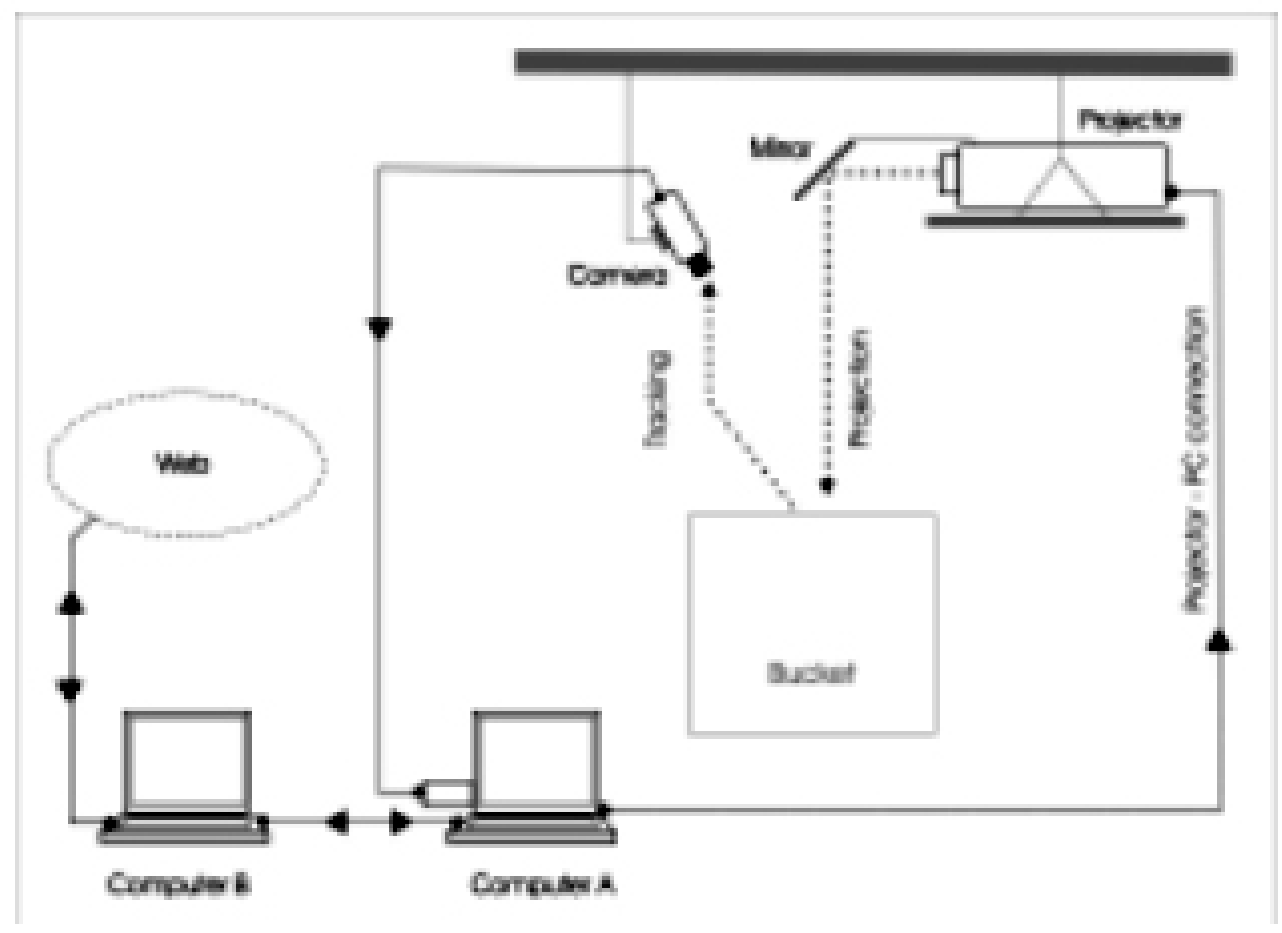

Ilustración 11 Esquema general de la instalación 1. Efecto mariposa - Instalación interactiva-Patricio Gonzalez

${ }^{16} \mathrm{https}: / /$ vimeo.com/32321634 minuto $2.19-3.19$ 


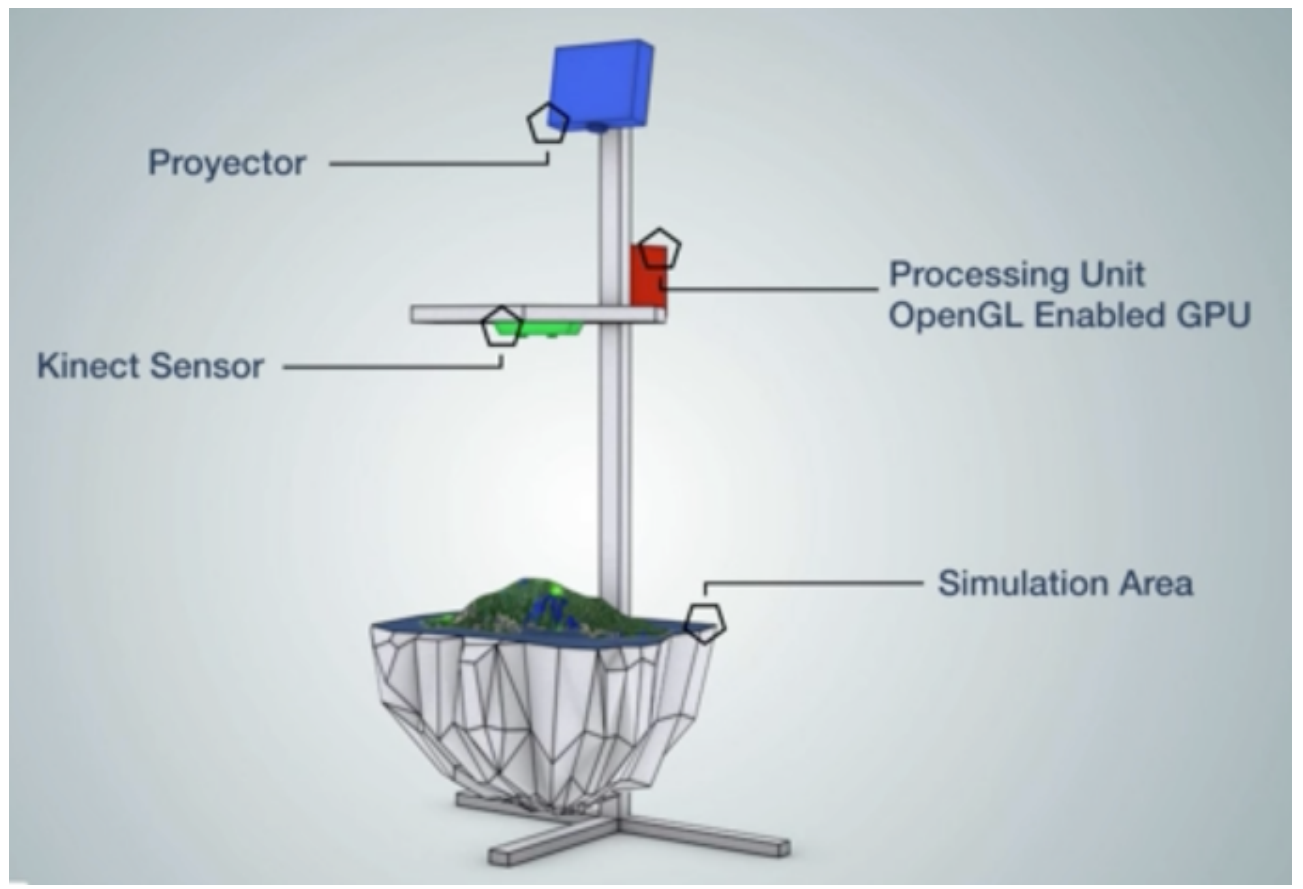

Ilustración 12- Esquema general de la instalación 2. Efecto mariposa - Instalación interactiva - Patricio Gonzalez

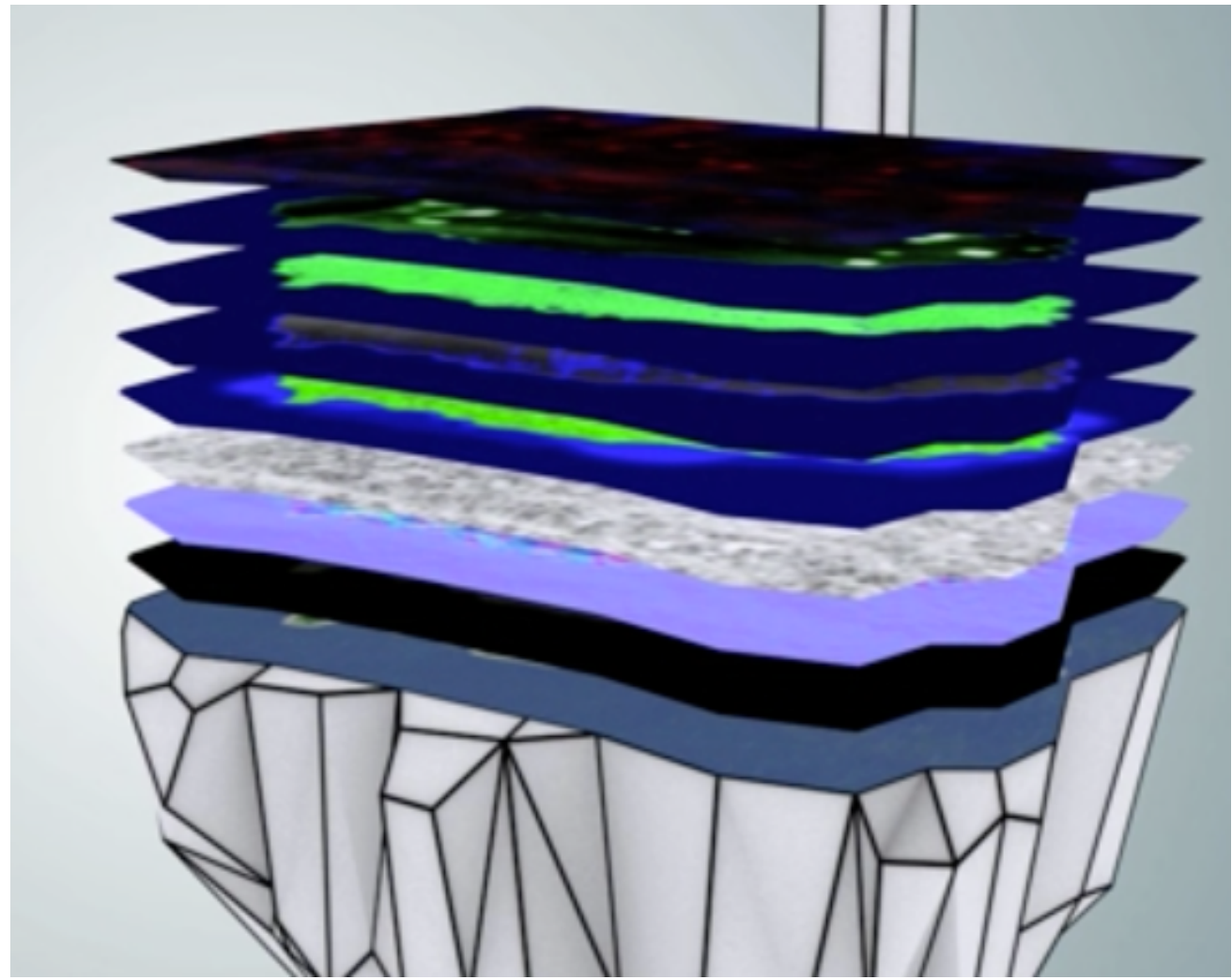

Ilustración 13 - Representación de capas - sustratos. Efecto mariposa - Instalación interactiva - Patricio Gonzalez 


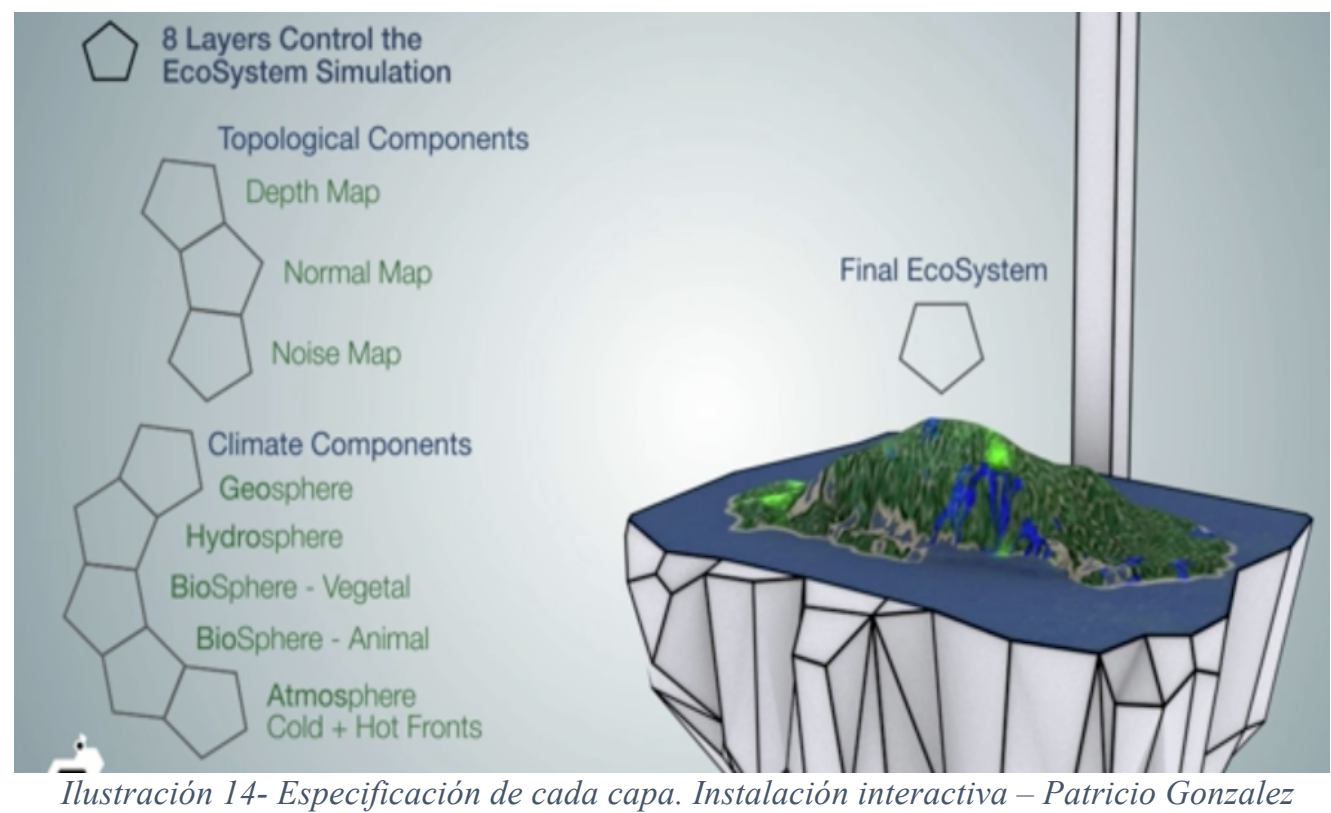

Como se afirmó anteriormente, el rol tradicional ${ }^{17}$ se vio cuestionado en esta instalación. Se produjo una expansión de dicho papel. La noción de interactor se configuró en la medida que se propició un rol específico. Los visitantes de las exposiciones en la escena del Arte electrónico del 2011, en el espacio expositivo del CCEBA, en cierta manera eran espectadores avisados y dispuestos a dejarse permear por los proyectos de este género. La obra favoreció la participación la cual dibujó nuevos comportamientos tales como:

1. Interactuar de manera consiente con la obra.

2. Entrar en contacto real con la interfaz propuesta.

3. Modificar de manera deliberada o lúdica la topografía del paisaje.

4. Generar ecosistemas diversos que activaron el sistema una y otra vez en respuesta a las nuevas condiciones o informaciones censadas.

5. Interactuar y dialogar a su vez con otros.

Como se puede observar las relaciones que se establecieron con la instalación fueron complejas. Se provocaron diálogos gestuales, se construyeron atmósferas de color, se sucedieron dinámicas temporales entre las cuales participantes y obra propiciaron múltiples simulaciones ecológicas con sus características propias.

\footnotetext{
${ }^{17}$ La noción de público en público estudio se tomará desde la acepción general del que asiste y participa en el espacio instalativo, con la intención de acercarse y dejarse permear por las intenciones del artista a través del diseño de la obra.
} 
A continuación, las observaciones que al respecto hizo Patricio Gonzalez con relación al rol de interactor:

"Creo yo he vivido un aprendizaje inverso. A lo largo de estos dos años haciendo la maestría en diseño y tecnología, mucho de los compañeros viene del diseño y se refieren a las personas como usuarios, "users testing de la obra" lo cual tiene sentido en el contexto americano dado que la relación servidor-cliente es base del sistema capitalista. Sin embargo, cuando escribo en mi blog o escribo un "paper" utilizo la palabra interactor a pesar que dicha palabra es también fría, y a la vez me parece algo muy técnico. Usuario no funciona, público tampoco, me remite al teatro. Creo estamos en un momento de transición y hay que pensar en nuevas palabras. Finalmente, interactor es la más cercana, es perceptible y creo con los días aparecerá un nuevo término" (P. Gonzalez, comunicación personal, 12 de agosto de 2014).

Más adelante el artista comentó con relación al papel de la interfaz: "Yo quedé muy satisfecho con la interfaz, considero que terminó siendo muy transparente. (...). Dentro de la obra por ejemplo hay la posibilidad de mover las nubes que cargan distintos tipos de humedad, sin embargo, el interactor no lo logra visualizar.” (P. Gonzalez, comunicación personal, 12 de agosto de 2014). Y con relación a los artefactos utilizados afirmó: "el placer radica en descubrir cómo funciona y cuáles son sus mecanismos de interacción. Yo siempre dejé la cámara expuesta a la vista. El espectador se siente tranquilo cuando descubre que hay un sensor allí.” (P. Gonzalez, comunicación personal, 12 de agosto de 2014).

Continuando con la interfaz, el lugar protagónico de la ceniza volcánica fue indiscutible. A pesar del componente visual estratificado altamente atractivo, el sustrato matérico (que recuerda la obra Libros de arena de M. Sardón) fue la principal fuente de experiencias que apeló al tacto, la visión, y al olfato.

Como se observa todo el dispositivo puesto en escena tuvo por objetivo generar un horizonte nuevo de actuación, por medio de una experiencia inmersiva e interactiva, en torno a la temática de vida artificial, generación de simulaciones y realidad virtual. En particular el efecto inmersivo de la obra se detalló de la siguiente manera por Patricio Gonzalez:

"Lo bueno de la obra Efecto Mariposa es que no estoy proponiendo un universo simbólico muy distinto del real. Los signos que estoy proponiendo son agua, lluvia, ríos, y vegetación que se presentan a escala de la obra, escala macro y que 
funciona mucho más rápido que en la realidad. (...) Creo que el éxito de la obra radicó en el hecho de que no necesita mucho para sumergirse en la realidad de la obra y olvidar la propia.” (P. Gonzalez, comunicación personal, 12 de agosto de 2014).

El espacio instalativo y la atmósfera de la obra estuvo condicionado por la proyección visual, de ahí la atmósfera de penumbra y atracción que la obra produjo. Patricio Gonzalez dijo lo siguiente en relación a la obra cuando fue invitado a participar en FILE18:

"En FILE se me asigno un espacio con éstas características, también yo siempre pido un espacio de silencio para la obra, solicito ciertos indicadores que hagan que la obra no sea un lugar de paso. Por suerte siempre se le asignó a la obra el espacio adecuado de penumbra y silencio, el cual generó una escena en cierto sentido mística que le da el tono a la obra que yo esperaba, además invita a la contemplación, atrae y hace que el interactor participe de la propuesta." (P. Gonzalez, comunicación personal, 12 de agosto de 2014).

La instalación interactiva Efecto mariposa, en su momento innovo en tanto hizo uso de la tecnología disponible en aquel entonces. La Kinnetic, hizo su aparición en el medio, y posibilitó un giro novedoso en la escena del Arte electrónico de Buenos Aires. Al respecto Patricio Gonzalez expresó:

"Creo que la obra tuvo mucho del estado del arte de ese momento, de la tecnología disponible en ese momento, formo parte del boom innovador de la kinect, si yo no hago esa obra, otra persona la habría hecho, la kinect pide a gritos que se le dé público tipo de usos. Si fue innovador en el medio el uso de la kinect. A Emiliano Causa le atrajo el proyecto creyó en él y en el CCEBA se pudo concretar. Yo sentí que el medio fue muy generoso conmigo. También considero que por esos días se producía mucho discurso, los proyectos que se presentaban tenían un fuerte componente conceptual, apoyados en teóricos como Lacan y Foucault, en contrapartida yo quería hacer algo fresco, sin manual, algo sencillo, experiencial, sin un discurso teórico complejo. Como sabes yo vengo de la sicología, y desde esa perspectiva creo sorprendí a la escena del arte electrónico de Buenos Aires, porque la obra no venía de un discurso lacaniano complejo o un discurso simbólico complejo,

\footnotetext{
${ }^{18}$ Festival Internacional de Lenguaje Electrónico
} 
en ese sentido fue algo sencillo, muy experiencial y lúdico.” (P. Gonzalez, comunicación personal, 12 de agosto de 2014).

En conclusión, Efecto mariposa instalación interactiva, introdujo a la escena del arte electrónico de Buenos Aires formas de interacción novedosas apoyadas en el uso de código abierto. Configuró al púbico como interactor en tanto que este se relacionó con la instalación y su espacio; se sumergió en la temporalidad de la obra, dialogó con el dispositivo, activó mecanismos de respuesta diferentes a cada transformación que generó; con sus manos gesticuló sobre la interfaz explícita; participó en el proceso de activación, y modificó creativamente tanto la obra como su papel. 


\subsubsection{Calor, Humedad y Vapor. Turner en el Siglo XXI - instalación interactiva - Marina Zerbarini}

“Calor, Humedad y Vapor. Turner en el Siglo XXI es una instalación interactiva electrónica que propone reflexionar sobre nuestro lugar en el mundo y sobre nuestra incidencia sobre él. Mediante la manipulación de las condiciones de luz y humedad de un micro- entorno cerrado y vivo, los espectadores pueden experimentar los efectos de su acción sobre fenómenos atmosféricos circunscriptos, como metáfora de su intervención a nivel global. La instalación está compuesta por una maqueta urbana que representa edificios y plantas, de gran atractivo visual, dotada de un sistema de interacción simple y de respuesta inmediata: basta apoyar las manos sobre sensores para poner en funcionamiento la pieza. A pesar de su complejidad tecnológica, su uso es intuitivo y dinámico.” (Zerbarini, 2006)

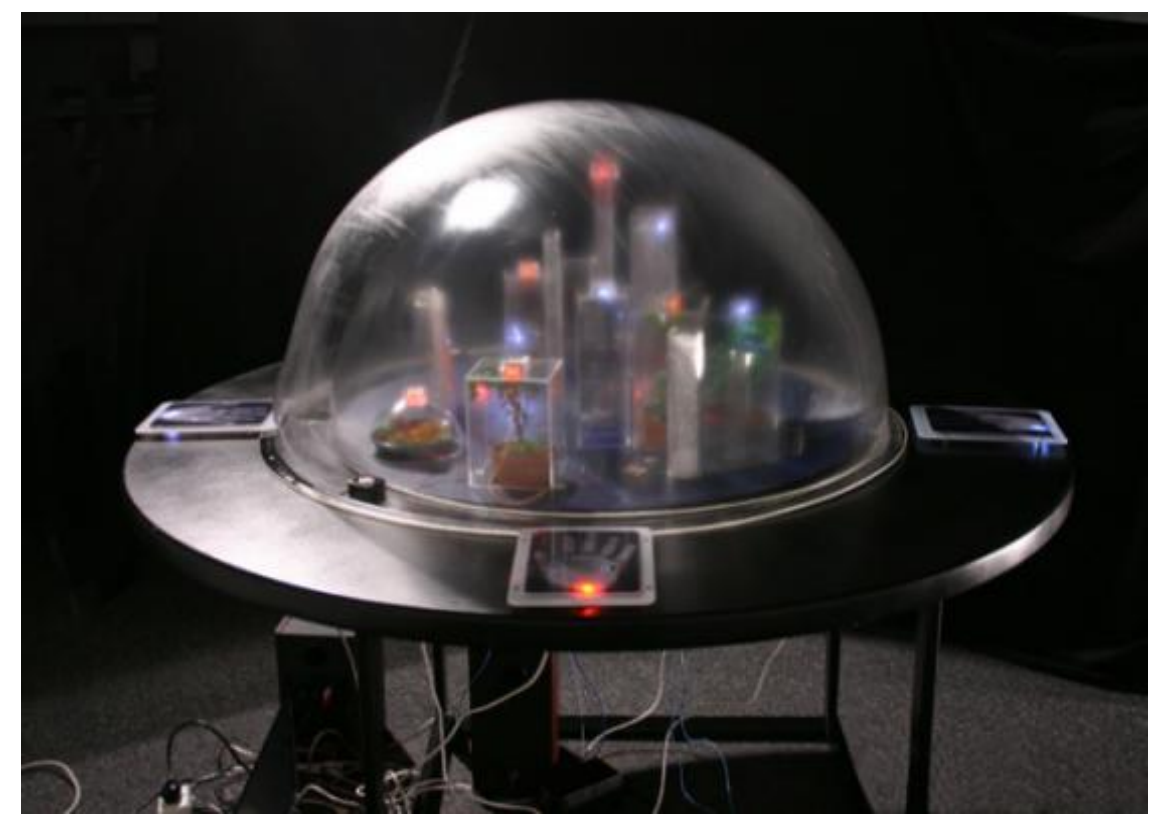

Ilustración 15. Calor, Humedad y Vapor. Turner en el Siglo XXI. Instalación interactiva. Marina Zerbarini.

La obra como lo reseñó la artista se diseñó en torno a las relaciones que el hombre establece con su medio ambiente. Investigó en torno a variables de orden físico como son: la temperatura, el calor y la humedad, en un espacio instalativo cerrado. Se alineó el proceso de producción en el eje de investigación arte, ciencia y tecnología. Con relación a lo anterior dijo la artista: "Es un área en que resulta complejo definir la dimensión artística, por el 
contrario, la experimentación en la producción se adecúa con mayor fluidez. Dentro de la investigación he puesto de manifiesto mi interés en los sistemas ecológicos y relaciones humanas, temas de género y participación colectiva.” (Zerbarini, 2006)

La obra se circunscribió en una temática eco-biológica. Se enfocó particularmente en los fenómenos de vapor, calor y humedad, los cuales se utilizaron con el fin de generar un micro-ambiente. Al respecto, en la entrevista Marina Zerbarini dijo:

"El tema del vapor hace referencia a los asuntos atmosféricos y climáticos, los cuales tendrán diversas connotaciones dependiendo del lugar en donde se exhiba la obra (...) las plantitas naturales que están al interior de su habitáculo generan su propio ecosistema, produciendo vapor y humedad independiente del vapor de la otra semiesfera que se genera cada diez minutos o por la interacción de los espectadores a través de las manoplas.” (M. Zerbarini, comunicación personal, 28 de agosto de 2014).

La obra propuso establecer una relación entre la temperatura procedente de las manos del público y la posibilidad de generar vapor y humedad al interior de la capsula que contiene el micro-ambiente. El funcionamiento del sistema dependía básicamente de que el calor generado con las manos, alcanzara los sensores de temperatura, los cuales a su vez activarían un vaporizador y un sistema de luces. Marina Zerbarini se refirió al respecto así:

“...el espectador participa individualmente, hay sensores de temperatura en cada una de esas manoplas, que están tomando la temperatura de cada persona, y que aleatoriamente va a hacer un juego de luces que responden a una programación que genera sonidos, y que en este caso en vez de generar sonidos generan luces, eso también es aleatorio.” (M. Zerbarini, comunicación personal, 28 de agosto de 2014). La obra exploró las consecuencias que resultan de la manipulación de las condiciones climáticas mediante la alteración del vapor y la humedad por parte de los seres humanos. Esta instalación esbozó una metáfora que pretendió concientizar a los asistentes sobre el delicado y frágil equilibrio climático del planeta. Los participantes, siguiendo un conjunto de instrucciones dadas, interpelaron el ambiente o ecosistema producido artificialmente.

Por medio de un texto explicativo se invitó a interactuar de determinada manera con la instalación, con el fin de generar procesos que activaran la instalación. La artista al respecto puntualizó: "Sí, hay indicaciones sobre como apoyar la mano por parte del espectador, el 
público es un público importante, las indicaciones hablan de que la temperatura de las manos va a ser censada, que se trata de un entorno natural, y que algo de su cuerpo va a ser intervenido." (M. Zerbarini, comunicación personal, 28 de agosto de 2014). El público al participar sigue una línea de instrucciones que le son dadas de manera explícita, instrucciones previas que hacen referencia a varios aspectos:

1. La temperatura corporal será censada

2. Dicho proceso será posible en la medida que pose las manos en un lugar específico, $\mathrm{y}$ por un tiempo $\mathrm{x}$,

3. Dicho lugar son unas manoplas diseñadas específicamente para que mida las variaciones de temperatura que sufre la manopla.

4. Pueden participar hasta cuatro personas al tiempo, situación que multiplica e incrementa la temperatura que será censada

5. La variable temperatura es el factor activador de los procesos que la instalación propone.

El público accedió al juego participativo que le proponía la obra. De esta manera y guiado por un conjunto de instrucciones, transita hacia un nuevo rol que lo distancia del papel tradicional. Al respecto Marina Zerbarini precisó respecto de dicho papel lo siguiente: "Si el espectador es más social y si participan cuatro al mismo tiempo, entonces la temperatura de esas manos se puede sumar y con esto logran encender el vaporizador produciendo que se llene de vapor la obra, que es el efecto o el resultado esperado tanto por el espectador como por el artista." (M. Zerbarini, comunicación personal, 28 de agosto de 2014). El tránsito por parte del público hacia un nuevo rol es evidente. Retomando la definición de usuario ${ }^{19}$ elaborada en el capítulo cuatro del presente estudio, se podría afirmar que, en esta instalación, el público estableció dicho rol en tanto:

19 "Para efectos de la presente investigación se denomina al público de las instalaciones interactivas y robóticas usuario, cuando la relación que establece con el dispositivo se origina a partir de una instrucción puntual que generalmente es visible, evidente y está escrita en una nota de programa y la cual induce al público a asumir un rol de uso. Es decir, la participación del usuario está mediada por un conjunto de instrucciones, que al seguirlas producirán la activación de la instalación y los mecanismos del sistema diseñados por el artista. Generalmente dichas instrucciones implican la manipulación directa del dispositivo en cierto orden o con cierto nivel de jerarquización, y es en esa mediada que la interacción se produce y los efectos esperados por el artista se suceden o no." 
1. Su actuación se moldeó por una información previamente establecida, consignada en una nota de programa.

2. Se estableció una relación de uso con la obra, en tanto que la participación del usuario buscó generar la obtención de unos resultados esperados. En este caso generar vapor y humedad con el fin de activar todo el mecanismo propuesto

3. La activación del dispositivo requirió colectivizar la intención participativa del usuario, con el fin de alcanzar la temperatura suficiente para poner en funcionamiento el sistema.

4. El proceso dialógico que se estableció entre usuario y obra generó un bucle participativo, que se mantuvo activo, en tanto el usuario o los usuarios, continuaron suministrando calor al sistema.

La obra logró exopandir el rol tradicional hacia el rol de usuario, a diferencia de la noción de actor o interactor que se logró en obras como Tango Virus y Sensible del Grupo Biopus. Sin embargo, es importante anotar que los usuarios de esta instalación en un momento dado, luego de activar todo el sistema, se sumergen en la realidad de la obra. Con relación a esto la artista dijo:

"El espectador hace contacto con las manoplas, se queda observando la naturaleza interior de la obra, observa las variaciones de intensidad de la luz, y del sonido, los cuales responden a la programación pre-establecida según la temperatura ambiente, de manera que si tenés un ojo fino entrenado, podés sumergirte en las variaciones lumínicas.” (M. Zerbarini, comunicación personal, 28 de agosto de 2014). De lo anterior se deduce que en la obra Calor, Humedad y Vapor. Turner en el Siglo $X X I$ el público facetó roles diferenciados. El de usuario en tanto se involucró con la obra, accedió a ella, siguió las instrucciones y desencadenó procesos de luz, sonido, vapor y humedad. De otra parte, una vez alcanzó la obra cierto estado de equilibrio, (dado que el flujo de calor proveniente del usuario se estabiliza), el usuario inmerso en la temporalidad de la obra asumió un rol de espectador ${ }^{20}$. Espectador, en tanto presenció, las variaciones físicas

${ }^{20}$....aquí en este estudio se tomará el termino espectador desde la acepción general del que asiste y presencia un espectáculo, en el sentido que Jonathan Crary le asigna cuando afirma: 'La palabra 'espectador' conlleva connotaciones específicas, concretamente, las de ser el asistente pasivo de un espectáculo, como en una galería de arte o en un teatro.” 
que la obra sufre, causadas por la variación de temperatura al interior del ambiente cerrado de la instalación. En el anterior sentido, la artista amplió dicha percepción cuando afirmó:

"Las personas en la interacción se quedan como acariciando las manoplas, atrapados por la atmósfera que observan y el ecosistema de las plantitas, a pesar de la dureza de las manoplas. (...) Los prismas instalados reflejan unos textos al revés, proyectados desde una filmina, los cuales capturan la atención del espectador en su intento de descifrarlos lo cual es imposible.” (M. Zerbarini, comunicación personal, 28 de agosto de 2014).

La producción estableció una relación dialógica entre el usuario y la obra. El diseño de la instalación, propuso maneras específicas de interacción, individuales y/o colectivas. Como el descubrir que, colectivizando la participación, el gradiente de temperatura se incrementaba y de esa manera era posible activar el sistema totalmente. De hecho, los participantes modificaban los algoritmos y procesos de respuesta del sistema en la medida que podrían llevarlo a un punto de desequilibrio.

Se producen entonces dos planos de realidad: la realidad de la obra, en la cual diversas variables de orden físico intervienen y se manifiestan a través del micro ambiente creado, y de otro lado, el proceso de subjetivación de la vivencia. Lo anterior, mediado por la observación del micro ambiente dinámico y las posibles inferencias en relación con el propósito de la obra de llamar la atención acerca de los problemas atmosféricos del planeta causados por la intervención humana.

Con respecto a los componentes científicos y tecnológicos y su impacto en la escena local del arte electrónico Marina Zerbarini opinó lo siguiente:

"Sí, tiene que ver con lo natural, la temperatura y la humedad, ver cómo reacciona el vapor, el componente biológico que tiene que ver con las plantas, eso es lo que tiene de ciencia. De tecnología todo lo que tiene que ver con las interfaces, dispositivos, sensores, el manejo de las respuestas que dan los sensores. En cuanto a lo científico, tiene que ver con la concientización que permite la obra con respecto a la incidencia de lo humano en el mundo, todos participamos." (M. Zerbarini, comunicación personal, 28 de agosto de 2014).

Y más adelante ella afirmó con relación a la novedad de la obra en el escenario local del arte electrónico: 
"Lo innovativo de la obra en la escena de Buenos Aires en el 2005 creo que fue el componente biológico, hubo una preocupación por el diseño del entorno, el hecho de trabajar con luz, con LEDs nos llevaba a diseñar una vidriera cosa que no se quería, por lo tanto, se requirió un estudio profundo de los prismas, su escala y su funcionamiento, para que no parecieran envases y lograr salir de la imagen del mercado, del diseño, del consumo y romper de alguna manera esa forma. El tema del vapor y su relación con lo biológico yo creo que fue un elemento innovador." (M. Zerbarini, comunicación personal, 28 de agosto de 2014).

En síntesis, a través del análisis de la obra se constató como Calor, Vapor, Humedad - Turner siglo XXI introdujo en el horizonte del arte electrónico en Buenos Aires, elementos afines a los ejes ciencia, tecnología y arte. El componente biológico fue un factor diferenciador para la época y el cómo a través del diseño de la instalación se construyó la noción de usuario en el público de aquel entonces. 


\subsubsection{Los Aparatos - instalación Interactiva - Federico Joselevich - Julia Vallejo}

"Una instalación de arte, tecnología y transliteraciones psicoanalítica.

Descripción: la instalación consiste en un conjunto de esculturas, diagramas, atriles y stands con herramientas, aparatos y planos de laboratorio de inventos, algunos de forma clara, otros simplemente lo rememoran. Los Aparatos es una instalación en donde se conjuga la ironía de que la tecnología puede solucionar todo, con la poesía utilizada como catarsis. Pone en cuestión la compra de soluciones pre moldeadas para conflictos singulares. Critica las ofertas de felicidad y bienestar a través de objetos de consumo masivos dictados por discursos universalizantes. La tecnología como alimento del confort, la farmacopea moderna y occidental naturalizada como la forma ideal de curar-, los objetos de consumo cotidianos, obvian la pregunta acerca de lo singular y de lo particular a cada cultura en su forma de enfermar, sufrir, disfrutar y curar, atenta contra la diversidad cultural. Son diez objetos/prototipos simulando un funcionamiento de laboratorio y el visitante interactúa aportando diferentes elementos a la propia instalación. Los inventos: "Extractor de las angustias de cuando se va el sol", "Humidificador en aceite de amistades oxidadas", "Resignificador de años perdidos", "Transcodificador de estados de ánimo no definidos", "Extractor de pensamientos enquistados", "Triturador de sentimientos culpógenos", "Envoltorio, cubre cuerpo para Tiempos Difíciles",

"Desomblificador/ omblificador", "desintelectualizador", "Acelerador de tramitaciones psíquicas". (Joselevich, 2010)

Los Aparatos, surgió a partir de la observación y reflexión sobre la conducta y los comportamientos del ser humano inmerso en una sociedad de consumo. Los inventos, como los denomina el artista, fueron una mezcla de artilugios tecnológicos, textuales y contextuales. El componente sicológico jugó un papel central en la puesta en escena de los diferentes aparatos. Los nombres dados a cada aparato fueron sugestivos y sorprendentes, rayando con el absurdo. Nominaciones que generaron una nomenclatura totalmente metafórica. La instalación ahondó en la construcción de la noción de usuario. Se estableció cierto paralelismo entre el uso de electrodomésticos y la posibilidad de experimentar a través de un conjunto de aparatos e instrucciones la solución a problemáticas típicas del consumidor en el plano sicológico. En la entrevista Federico Joselevich expresó al respecto lo siguiente: 
"Bueno con los aparatos, nos pasó una cosa muy particular, yo vengo trabajando con temas de interactividad, con la noción de usuario, más que de usuario, alguien que está del otro lado. Desde mis comienzos con la programación allá por los años 80's - 90's, trabajaba siempre con la idea de que al otro lado había alguien. Cuando la cosa empezó a cuajarse en el arte digital por allá a finales de los años 90, siempre pensé que la gente hace uso de lo que uno pone allí y no solo hace uso, sino que comienza a ser parte de ello, no solo como partícipe necesario sino como pieza más de ese rompecabezas; las discusiones académicas teóricas después comienzan a hablar de arte interactivo, y en particular de interacción como la acción entre dos." (F. Joselevich, comunicación personal, 2 de septiembre de 2014).

Para luego afirmar en relación al público y el plano sicológico en que se sitúa la obra lo siguiente:

"La obra se ubica en un plano sicológico, pensamos en el vocabulario sicoanalítico y en el significado profundo de la cosa, de otro la utilización recurrente de la palabra dispositivo como concepto desde lo sicoanalítico. En algunos casos la utilización de compuestos químicos para alterar el $\mathrm{Ph}$ y lograr el cambio de color de una cosa, a veces funcionó otras veces no. En general los dispositivos funcionan mecánicamente y en gran medida simuladas.” (F. Joselevich, comunicación personal, 2 de septiembre de 2014).

En síntesis, esta instalación, propuso una serie de electrodomésticos síquicos, por medio de los cuales se indagó en torno al deseo de los usuarios y la posibilidad típica del consumismo de encontrar una salida o solución rápida a las dificultades cotidianas. 


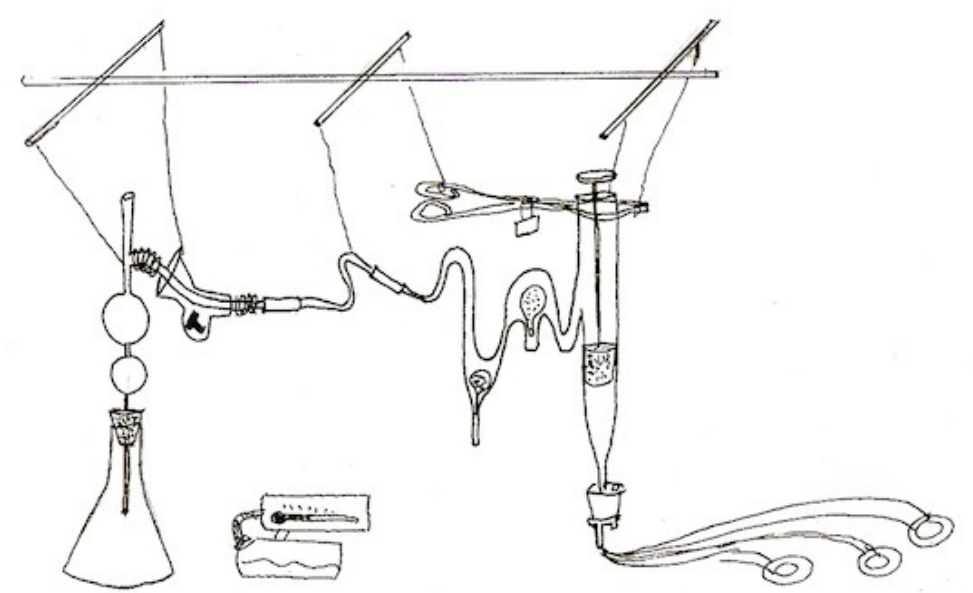

Ilustración 16. Extractor de pensamientos enquistados. Instalación interactiva. Federico Joselevich.

El diseño y construcción del sistema de cada uno de los aparatos propuestos por la instalación, se fundamentó en tres planos a saber:

1. Un primer plano referido a las formas de acercamiento a la obra y al conjunto de instrucciones acerca de la mecánica de funcionamiento de cada aparato.

2. Un segundo plano referido a la estética de los aparatos, a su formalidad individual, colectiva y espacial en el escenario instalativo.

3. Y finalmente un tercer plano que hizo referencia a las maneras o formas de relación e interacción entre el público, los aparatos y la obra en su conjunto.

Las soluciones tecnológicas para el funcionamiento propio de cada aparato se sustentaron en diversas estrategias, las cuales simulaban un dispositivo químico/orgánico. Dichas estrategias utilizaron Internet, sensores de presencia, micrófonos, cámaras, y termómetros entre otros. En total los diez aparatos puestos en escena invitaron al público a interactuar desde diversas lógicas.

La obra propició una experiencia espacial, la cual remitía al formato de feria de la ciencia. En el espacio los aparatos en cuanto a su formalización se situaron desde una misma perspectiva estética. Los diseños fueron atractivos y lograron cautivar la atención del público. El recorrido por los diversos aparatos fue una indagación que favoreció el acercamiento al ser del público. La obra necesitó de un espacio autónomo e independiente. En la práctica no comparte el espacio con otras instalaciones. Con relación al recorrido para experimentar la instalación el artista manifestó:

"En el caso de los aparatos nos hicimos la pregunta respecto al recorrido, si entras a ver la instalación con que aparato te encontrás primero, este o aquel. Primero 
que vas a hacer, ver cómo está tu estado de ánimo y después como te vas a proteger de los tiempos difíciles. De todas formas, el planteo del recorrido es sugerido." (F. Joselevich, comunicación personal, 2 de septiembre de 2014).

En el espacio expositivo, la instalación estuvo acompañada de una descripción impresa referida a ella misma como conjunto. Además, en particular, cada aparato estuvo acompañado de un conjunto de instrucciones adjunto que indicaba al público la manera de proceder para obtener los resultados esperados que cada aparato proponía. El artista Federico Joselevich explicó:

"Para cada uno de los aparatos de la instalación hemos hecho un prospecto médico una cosa muy de farmacia en el cual está toda la explicación e instrucciones respecto al aparato y la propuesta. Todas las notas tienen un tono como si fuesen un prospecto, médico o como si fuese la presentación de la empresa que te está vendiendo el aparato." (F. Joselevich, comunicación personal, 2 de septiembre de 2014).

Es importante destacar el anterior aspecto, dado que se generó la noción de usuario en la relación que el público asumió con la instalación. Fue evidente que, en esta obra, cada uno de los diez aparatos diseñados estuvo acompañado de un manual de instrucciones preciso y minucioso. Cada uno de los prospectos de instrucciones fue el resultado o el aporte de la participación de colaboradores a quienes el artista encomendó la tarea de escribirlo de acuerdo con el propósito y funcionalidad de cada aparato. A nivel de ejemplo, a continuación, las instrucciones que acompañan el Acelerador de tramitaciones psíquicas:

"Acelerador de Tramitaciones Psíquicas

Configuración del aparato para su uso.

Funcionamiento del aparato

1. Enchufe el aparato a la toma corriente (véase Precauciones de seguridad).

2. Siéntese en el pupitre. Atención: El uso probado en laboratorio es de tipo individual. Para una tramitación grupal o de pareja, se está desarrollando el ATP-MAX (aún en fase animal).

3. Escriba detalladamente el dilema, pensamiento, inquietud o pena que desea tramitar.

4. Comience a pedalear de forma constante. No se acelere. Para un perfecto análisis usted debe conseguir que la aguja del indicador se mantenga en cero durante unos segundos. No es una tarea fácil. Concéntrese en aquello que necesita tramitar. 
5. El ATP realizará un escaneo celérico-telepático para registrar el pensamiento elegido a tramitar (si le cuesta focalizar en un único pensamiento vea Repertorio de pensamientos tramitables más frecuentes). Si el ATP consigue captar su pensamiento y usted ha sido lo suficientemente paciente y veraz, una campana le indicará que el trámite ha sido procesado. Una mano automática bajará lentamente para sellar su trámite.

6. A tener en cuenta: como el ATP es de funcionamiento telepático-lacaniano, el silencio y/o ruido, así como cualquier movimiento de la máquina pueden interpretarse como modos de puntuar la tramitación sin necesariamente llegar al final. Esto puede ocurrir en cualquier momento del proceso de escaneo (e incluso antes de haberse sometido al mismo).” (Joselevich, Los Aparatos, 2010)
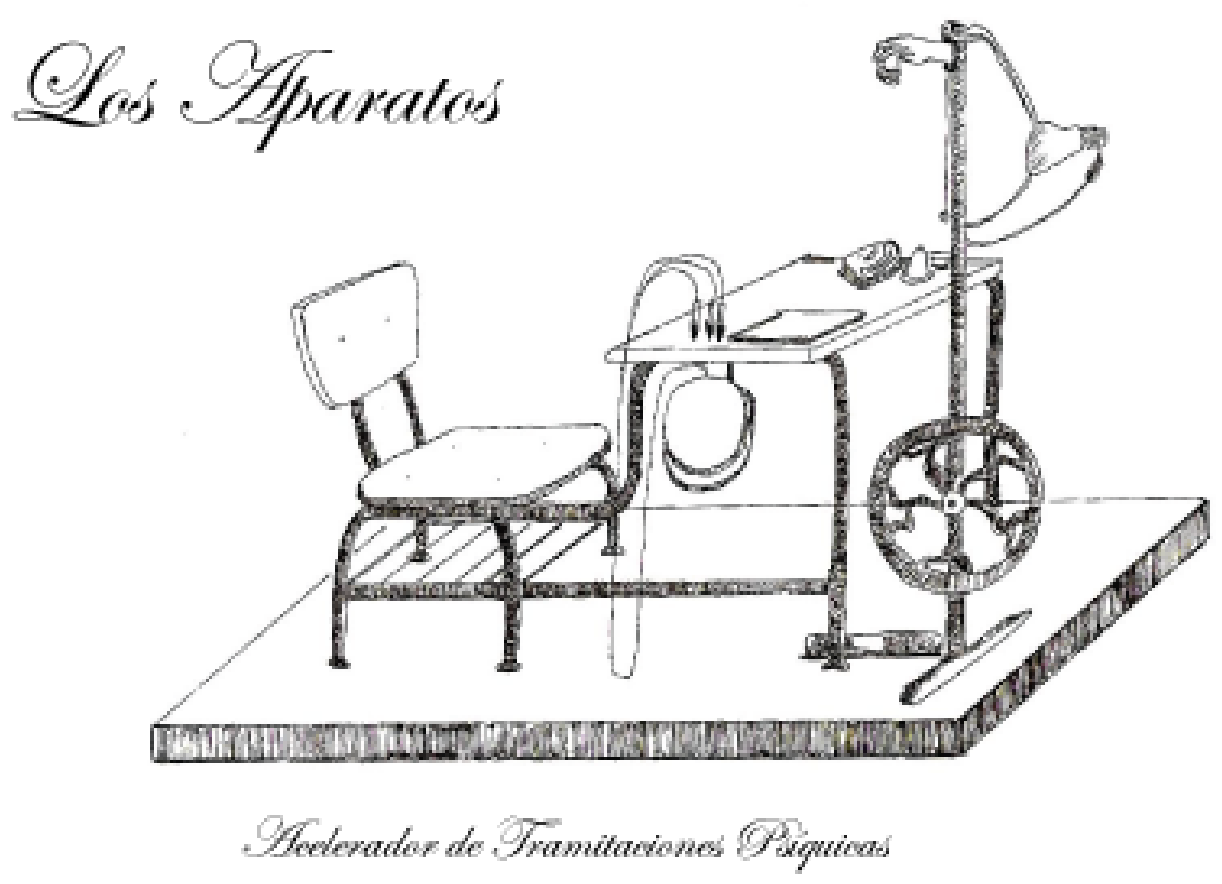

Ilustración 17. Acelerador de tramitaciones síquicas. Instalación interactiva. Federico Joselevich.

De hecho, el aparato citado en el párrafo anterior, indujo al público a asumir un rol de usuario frente al objeto. Inducción que provenía del conjunto de instrucciones escritas y que de una u otra forma moldeaban la interacción o relación que se establecía con el aparato. hubo interacción y manipulación del aparato en virtud de la mediación que provenía del 
conjunto de instrucciones dadas. La activación del objeto requirió de manera decisiva la participación. Los mecanismos diseñados se activaban y generaban la ilusión o simulación de la función. Es preciso anotar, que el conjunto de instrucciones predeterminadas, debía seguirse en un orden o siguiendo un patrón de jerarquización.

El usuario una vez se involucró con la instalación, estableció una relación consiente que le permitía en cierta medida un distanciamiento de la misma; lo cual generaba dos planos de realidad: la realidad misma de la obra a través de su funcionamiento y la realidad del usuario, realidad que fue producto del proceso de subjetivación a partir de la experiencia de uso vivenciado.

La instalación interactiva Los aparatos, se posicionó en la escena del arte electrónico en Buenos Aires, como una primicia, en cuanto, al tratamiento sicológico que se le dio al usuario. Al respecto Federico Joselevich puntualizó:

La obra sobretodo innova en la manera de tratar a la gente, en la manera como se inscribe con los demás, no es un tobogán lúdico, no es una pantalla o espejo transformante. Es un lugar abierto donde puedes hacer lo que quieras, tú tienes problemas como los tengo yo, entonces te puedes sentar y dialogar de tus problemas con la obra, me parece que esto es lo más trascendente a nivel de la propuesta como novedad.” (F. Joselevich, comunicación personal, 2 de septiembre de 2014). 


\subsubsection{Generación de Conciencia II - de la serie@Agua_Y_Aceite Video instalación interactiva, Daniel Alvarez, Olmedo, Diez Diego, Guido Villar}

"Generación de conciencia II es una video instalación interactiva de la serie @Agua_Y_Aceite que toma información de una Base de Datos de la Tasa de mortalidad de la población total del país desde 1980 hasta el año 2007. La interfaz de la obra, procesa y controla los datos alfanuméricos a través de la programación activando la búsqueda de textos y números en porcentajes que son reflejadas en pantalla, dicha lectura también actúa manipulando el video visualizado en el sector izquierdo de la imagen con forma de suero de hospital. Este elemento contiene en su interior un líquido indicador $\mathrm{pH}$ de color rojo, video previamente grabado, que representa la sangre de los muertos en \%. Del costado derecho de la pantalla, se verá el resultado grabado con anterioridad del comportamiento de micro-organismos vivos en agua, que al caer la gota actuarán aglutinándose y devorando la composición. El objeto compuesto por una pantalla LCD y un computador realiza cálculos sobre la información inicial suministrada por la estadística de los años 1980, 1990, 2000, 2004, 2005, 2006 y 2007, por consiguiente, en los años de mayor mortalidad el dispositivo goteará con mayor rapidez que en los años de menor mortalidad, y el líquido que gotea se diluirá en menor y mayor medida en sincronización con esta información estadística. Un sensor ubicado en la parte superior del objeto, detectará la presencia del espectador afectando la velocidad con que son mostrados los datos y por consiguiente la rapidez del goteo en pantalla y la actitud de los micro-organismos en el agua.” (Álvarez D. , 2012)

En este proyecto de video instalación interactiva, se identificó un proceso en el cual se relacionó el fenómeno de la mortalidad a nivel estadístico, con el componente social del mismo, y el impacto que dicha relación generaba en el entorno especifico de la Argentina. El proyecto en lo conceptual se relacionó con la desigualdad social existente, profundizó en la crítica y visibilización de las situaciones complejas que vivencian aquellas personas que no pueden acceder a sus derechos básicos. El proceso de marginación excluye a las personas o grupos de la plena participación en el campo de la salud. Este proceso se caracteriza por: recursos precarios, ausencia de obra social, privaciones múltiples, exclusión, y deficiencia de la infraestructura sanitaria. La indagación del proyecto se instaló en el cruce de ciencia, arte 
y tecnología. Se experimentó con Software open source, placas arduino, manipulación de microorganismos provenientes del laboratorio y alternativas de interacción a partir de cámara y sensor de movimientos. Respecto a las pesquisas del proyecto el artista aclaró:

"En nuestros trabajos hacemos mucho hincapié en lo que es la investigación, en esa época habíamos estado trabajando en el laboratorio de bio-arte de la universidad Masmónides, y ahí es donde hacemos todos los procesos de investigación de los microorganismos, visualizaciones y una de las cosas particulares que nosotros tenemos es que no trabajamos solos, siempre trabajamos con bioquímicos.” (D. Álvarez, comunicación personal, 23 de septiembre de 2014).

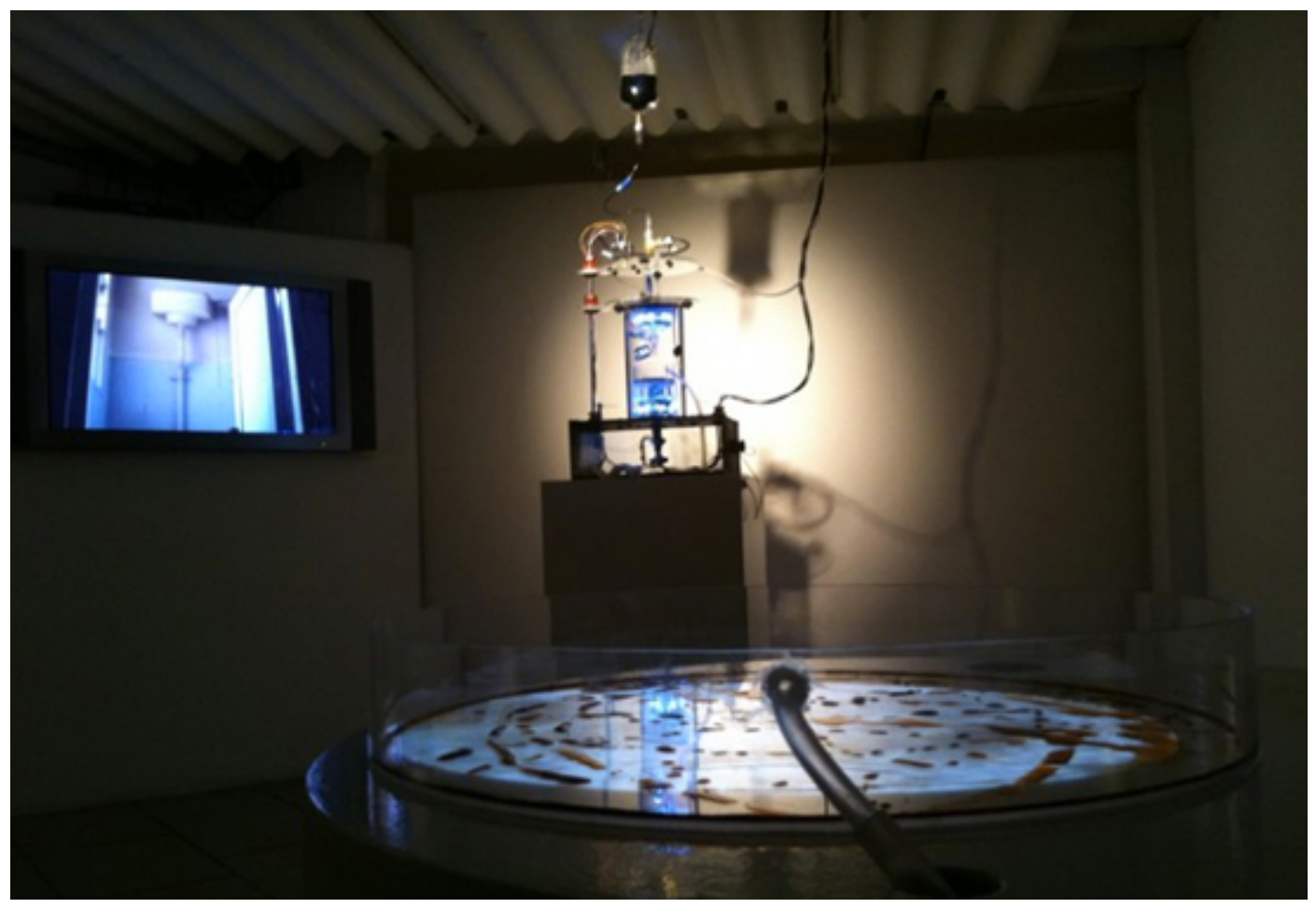

Ilustración 18.. Generación de Conciencia II - de la serie@Agua_Y_AceiteVideo instalación interactiva.

Ésta instalación tuvo una estrecha relación con Generación de Conciencia I. Parte de la información procesada en dicha obra fue compartida y sirvió de información útil para Generación de Conciencia II. A diferencia de la instalación Generación de Conciencia I, la cual transformaba los datos en elementos físicos, Generación de Conciencia II, trasformaba los datos en formas visuales. La producción contempló la participación del público desde la 
perspectiva del movimiento; un sensor cenital advertía el movimiento del público, al igual que su posición en un espacio cartesiano. De esta manera, se activaba el proceso de visualización y proyección de los datos estadísticos.

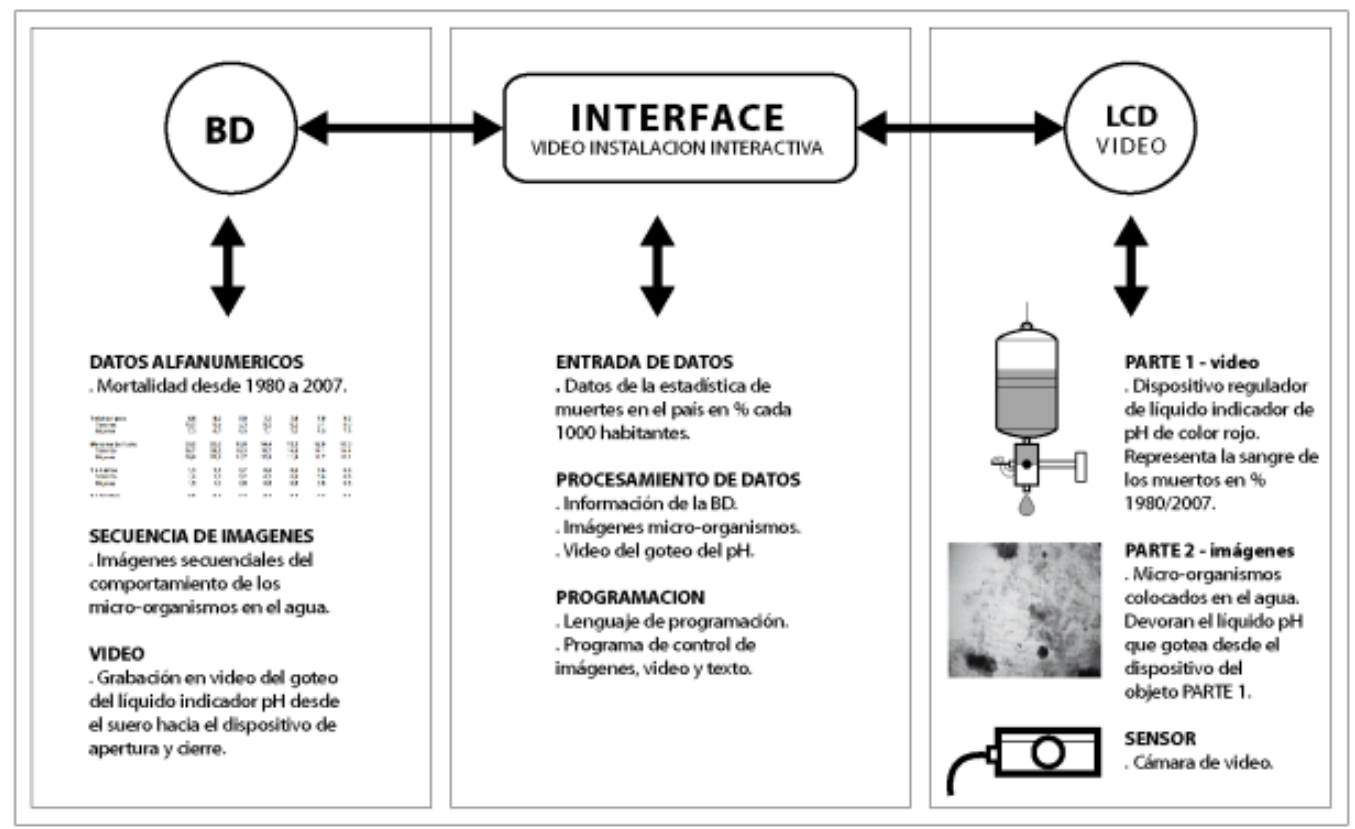

Ilustración 19. Esquema simple del funcionamiento: Base de Datos + Internet + Objeto + Video.

Se puede entonces afirmar que la presencia y corporalidad de los asistentes, en el espectro del sensor modificaba los procesos algorítmicos de respuesta de la video instalación, produciendo una aceleración en la proyección de las imágenes; de no detectarse dicha presencia, la obra no se completaría y permanecería en cierto estado de reposo o latencia. El público en la medida que interactuó y se sumergió en la video instalación hizo conciencia de su rol y grado de incidencia en el proceso. Tanto la realidad interna de la obra asociada a cifras e imágenes de micro organismos, así como la realidad de los espectadores convivieron y construyeron el espacio/tiempo de la obra.

Con base en el análisis anterior y teniendo como base la noción de actor, se identifica como dicho rol se configuró en la relación performática que se estableció con la instalación. La obra en estado de latencia, esperaba un gesto, o una acción corporal, o cierta movilidad o desplazamiento por parte del actor. La información producida por la actuación era censada por el sistema creándose así un bucle interactivo a través del cual la activación del sistema 
se producía. Respecto a la interfaz de la obra el artista declaró: "Me parece que es un conjunto de cosas, no hay una sola, porque sin el espectador la obra está estática, la obra está ahí, el espectador y su interactividad con la obra generan una interfaz." (D. Álvarez, comunicación personal, 23 de septiembre de 2014).

Hubo transparencia respecto al artilugio tecnológico que proponía el diseño de la obra. Al respecto, el artista Daniel Álvarez afirmó:

"A diferencia de Toma de conciencia I, que es física, y que puede trabajar por si sola, más allá de que tenga una cánula que el espectador se coloca y le va tirando como si fuese una descarga pequeña en la muñeca que cae de cada gota, Toma de conciencia II sin el espectador no funciona, porque tiene unos anillos, que están estipulados alrededor, que están en el piso, el espacio expositivo es importante, se requiere un techo alto porque los anillos tienen que estar circulares, y es el espectador que en la medida que va entrando en el centro lo activa y va tirando los datos justo en el centro donde están los microorganismos. El espectador se vuelve partícipe de la obra." (D. Álvarez, comunicación personal, 23 de septiembre de 2014).

La diferenciación del público entre una y otra obra fue dada por las maneras de participación propuestas o diseñadas por el artista. Claudia Giannetti al respecto planteó en su libro Estética Digital "En un entorno interactivo, en el que el observador puede intervenir como emisor y manipular las informaciones audiovisuales existentes o generar nuevas informaciones, la significación y efectividad de la obra están condicionadas tanto a la actuación del interactor como al desempeño del sistema." (Giannetti C. , 2002, pág. 171)

El control que el actor tuvo en virtud de los grados de movilidad o actuación lo hicieron partícipe de una nueva realidad, en la cual, él tuvo un rol que fue necesario y complementario de la obra. Se creaba una ilusión de control, a la cual hace referencia Claudia Giannetti en el texto citado anteriormente cuando afirma "La ilusión de ser partícipe en el sistema interactivo se basa sobre todo en la estrategia de la obra de disimular el grado real de diálogo humano-máquina, o la propia existencia del mismo, mediante interfaces implícitas" (Giannetti C. , 2002, pág. 171)

La obra presuponía una actuación que trascendiera la pasividad del espectador. De ahí, un actor en circulación, en movimiento, que giraba en torno a la instalación, que propiciaba recorridos hacia su interior/exterior, y a la vez acercamientos y distanciamientos, 
infiriendo y experimentando las variaciones que su influjo generaban en el contexto. El actor así configurado, fue entonces capaz de con su movilidad por el espacio expositivo interactuar activar y ser testigo de las respuestas de la instalación en forma de imágenes en movimiento, aceleración y simultaneidad. La participación múltiple fue posible, dado que el espacio era abierto. Las relaciones que se establecieron en el espacio estuvieron mediadas por diversos componentes de orden tecnológico, referencial, conceptual, y virtual entre otros.

Las obras Generación de conciencia I- II de la serie Agua\&Aceite, en su momento optimizaron aspectos relacionados con diferentes variables en el orden de la ciencia, la tecnología y el arte, al respecto Daniel Olmedo explicó:

"Nosotros somos muy detallistas, esas obras tienen objeto, ensambles, programación, interactividad, visualización, se trabaja con proyector, con robótica, microorganismos vivos, se interactúa, se modifican en tiempo real, a través de un microscopio se visualizan en pantalla, me parece que es un combo de mucha cuestión técnica, pero también es un combo de muchas cuestiones conceptuales, y eso es lo que nosotros siempre hacemos, eso es lo que nos gusta, que si hay una perfección en lo técnico la halla igualmente en lo conceptual. La pluridimensionalidad que las obras convocan se convierte en un elemento innovador con referencia al contexto de Buenos Aires de aquella época.” (D. Álvarez, comunicación personal, 23 de septiembre de 2014).

Y luego contextualizó y afirmó con respecto a la escena del arte electrónico en Buenos Aires: "Yo creo que en ese entonces estaba Mariela Yeregui con su obra Proxemia, el grupo Biopus con su obra interactiva. Lo robótico era escaso y a la vez innovador. Nos hacíamos un planteo socio político, sentíamos la necesidad de expresarnos acerca de la vivienda, la salud, el trabajo, la educación y encontramos esta manera, otros iban por otro lado. Que haya sido innovador finalmente el tiempo lo dirá." (D. Álvarez, comunicación personal, 23 de septiembre de 2014). 


\subsection{Instalaciones robóticas}

\subsubsection{Proxemia - instalación Robótica - Mariela Yeregui}

"Proxemia es una instalación robótica interactiva basada en sistemas de Multiagentes autónomos en forma de esferas. Se trata de una comunidad de robots que reacciona a la presencia de agentes externos (espectadores, límites físicos u otras esferas). Las esferas ruedan libremente por medio de dispositivos mecánicos y gracias a desarrollos sensoriales de detección, tienden a desviar su trayectoria cuando se produce cualquier contacto físico. Proxemia es un proyecto de investigación y experimentación en el campo de la robótica, cuyo objetivo final es articular un sistema dinámico y autosuficiente, con memoria central de los comportamientos y de las derivas particulares de cada una de las esferas. Proxemia fue producido en el 2005 con el apoyo de la Fundación Telefónica y exhibido en la galería de dicha institución. (...) La instalación constituye una reflexión y puesta en escena de los conceptos de “distancia”, "contacto" y posición de los individuos en los escenarios actuales. Apunta a crear una comunidad de objetos, con comportamientos autónomos capaces de reaccionar a la dinámica general. Esta comunidad instala la metáfora social: individuos en continuo movimiento, evitando a otros individuos, más concentrados en el "movimiento" que en el objetivo de estos movimientos. Mi objetivo es crear un diálogo entre "unos" y "otros" a través de códigos que posibiliten una puesta en escena de la ambigüedad de la relación distancia/proximidad. Dentro de la esfera conviven dispositivos mecánicos y electrónicos, rotores y micro controladores, imanes y sensores. Esta amalgama de tecnologías, principios y paradigmas crea un universo interno y único de la esfera, imperceptible para el espectador. Lo que sí es perceptible es que, a pesar de sus caracteres particulares, hay una obsesión unificadora: el otro ya no es un interlocutor sino algo que debe ser evitado." (Yeregui, 2005) 


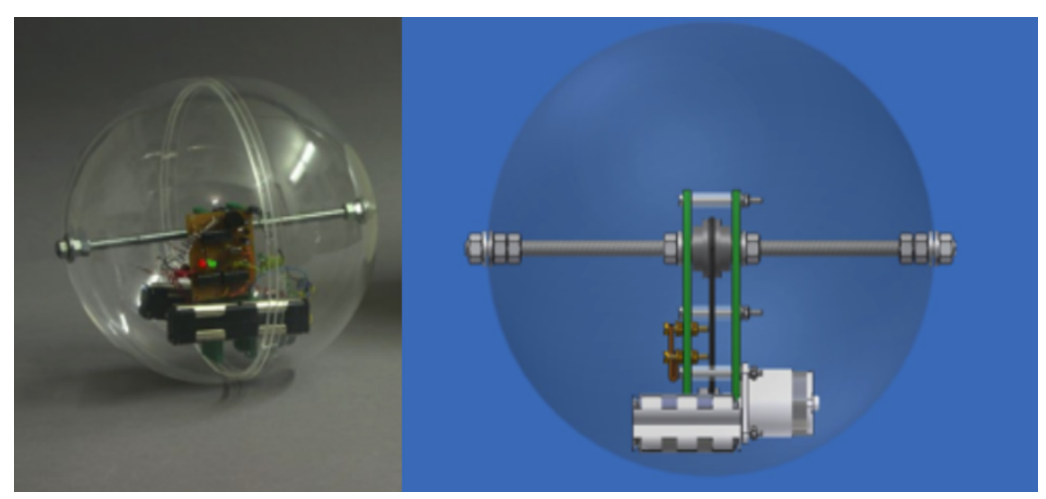

Ilustración 20.. Proxemia. Instalación robótica interactiva, Mariela Yeregui.

Proxemia fue el resultado de procesos llevados a cabo tanto a nivel tecnológico como conceptual. Esta obra favoreció las dinámicas interdisciplinares, es así como a partir de las tecnologías electrónicas en diálogo con las ciencias humanas, logró la convergencia de diversos lenguajes. Se ocupó del concepto proxemia que fue estudiado por el antropólogo Edward Hall y el cual hacía referencia a la ocupación del espacio, la estructuración intuitiva del lugar y la interacción entre público, artefactos y códigos. Como señaló David Oubiña en el catálogo de la exhibición:

"En la obra de Yeregui el movimiento de cada una de las esferas robot se constituye ineluctablemente sobre la presencia de la alteridad. Sería tentador ver una alegoría de los comportamientos sociales en la obra, aunque sin duda es más interesante considerarla como un puro mecanismo de funcionamiento, como un sistema dinámico en incesante transformación y cuyas coordenadas deben redefinirse continuamente." (Oubiña, 2005)

En la descripción de la producción se constata que uno de los objetivos de la artista fue generar pautas de comportamiento entre el público, las esferas y los límites espaciales establecidos. El diseño de la instalación en virtud de las tecnologías, principios y algoritmos que la soportaron, concibió un rol activo para el público, en la medida que su presencia, movimiento e interacción provocarían respuestas aleatorias por parte de los agentes robóticos. El juego de corporalidades versus el dispositivo robótico, develó espacios cinéticos que alteraban el ir y venir aleatorio de las esferas y en esa misma dirección el comportamiento del público. Respecto a la relación prosémica que se establece Mariela Yeregui afirmó: 
"Pasó algo muy interesante, creo que en cada contexto donde lo mostré hay un componente cultural y social del espectador que hace que la forma de relacionamiento sea diferente; pero si, en todos los casos hay un relacionamiento intuitivo. Por ejemplo, en el caso de Argentina la forma de relacionarse era de una manera, en el caso de Brasil veo comportamientos diferentes, no puedo hacer una generalización como para definirlos de una manera determinada, lo cual sería muy determinista. Sin embargo, veo algunas cosas que son diferenciales, en Alemania por ejemplo la gente tenía una actitud más de respeto, la gente no se metía tanto, no tocaba tanto. Entonces me preguntaba también si había un componente proxémico, porque la proxemia es algo cultural, habla de proximidades en el espacio social que están condicionadas por aspectos culturales y eso se notaba en cada contexto donde la mostré." (M. Yeregui, comunicación personal, 17 de junio de 2014).

En el espacio de exhibición la instalación no va acompañada de una nota de programa aclaratoria, situación relevante, lo que implica un público aproximándose a la instalación de manera intuitiva, sensorial y kinésica. Mariela Yeregui respecto a la nota de programa conceptuó: "La obra no la tiene. A mí me interesa mucho que las obras tengan su propia autonomía, generar obras que promuevan un acercamiento intuitivo, que el espectador pueda entender, así no sepa con exactitud qué es lo que pasa, pero sí desde lo sensorial involucrarse.” (M. Yeregui, comunicación personal, 17 de junio de 2014).

Se estructuró la instalación Proxemia en dos etapas: una conceptual y otra tecnológica. Se establecieron para la obra una serie de premisas que fueron retomadas del antropólogo Edward Hall y las cuales orientaron posteriormente el desarrollo y la producción de la instalación. Dichas premisas o categorías fueron:

1. "Distancia intima: Proximidad voluntaria entre la gente. La visión se distorsiona. Visión del detalle.

2. Distancia personal: Visión en foco. La otra persona puede ser tocada.

3. Distancia social: Transacción impersonal. "Nadie toca o espera tocar a otra persona."

4. Distancia Publica: Los detalles no son visibles. Para alcanzar a la otra persona, la voz tiene que ser amplificada." (Yeregui, 2005) 
Las dos etapas del diseño como lo planteó Mariela Yeregui en el documento presentado en las Séptimas jornadas de artes y medios digitales - Córdoba- Argentina - 2005 fueron:

Una primera etapa en la cual se formalizaron las posibilidades interactivas con base en sistemas de multiagentes autónomos. La artista precisó el término agente así: "entidad autónoma capaz de llevar a cabo tareas específicas por sí mismo o a través de la cooperación con otros agentes." (Yeregui, 2005) Se materializaron dichos agentes a través de volúmenes esféricos los cuales presentaban las siguientes características:

1. Capacidad autónoma de movimiento.

2. Desarrollos sensoriales de detección de movimiento

3. Y capacidad de desviar la dirección del movimiento a partir de la información censada.

Mariela Yeregui en esta etapa configuró las esferas como robots autónomos móviles en un entorno real no- estructurado. El principio de aleatoriedad e incertidumbre se dibujó en tanto que la participación del público sería una variable que modificaría el espacio instalativo, la movilidad y direccionalidad de los robots.

La segunda etapa se caracterizó por el proceso de codificación de la información censada y el análisis de la misma. Un sistema de computer vision sería el responsable de traducir dicha información y asociarlo a diversas variables que se determinaron previamente mediante ciertas reglas a saber:

1. Trayecto según coordenadas de alto y ancho del espacio.

2. Longitud de trayectoria rectilínea.

3. Frecuencia de rotación

4. Niveles de proximidad con otros agentes

La instalación desde su diseño, se preguntó por el público y su relación con la obra en el espacio expositivo. Pretendió re-significar la noción de público a través de procesos interactivos, de coordenadas espaciales, de encuentros relacionales aleatorios y de tecnologías específicas.

Se vislumbró entonces la noción de actor en la relación que el público estableció con esta obra robótica. La participación del actor se desmarcó de la mera recepción sensorial del fenómeno propuesto. Se produjo un tránsito hacia a una actitud activa. El cuerpo se 
transformó en una interfaz o superficie de contacto a partir del movimiento. Al respecto Mariela Yeregui expresó:

"Lo que se propone la obra es el contacto, la proximidad en un entorno social, en ese sentido podríamos decir que la interfaz es una interfaz de contacto que es el propio cuerpo de la esfera, además de los dispositivos electrónicos. Sin embargo, prefiero pensar en una interfaz a un nivel más conceptual en donde la superficie de contacto es el cuerpo, finalmente lo que planteo en la obra es el cuerpo como interfaz y como a través del cuerpo nos relacionamos en el espacio.” (M. Yeregui, comunicación personal, 17 de junio de 2014).

La movilidad de las esferas fue determinada por la participación individual y colectiva del público en su actuación, así como por cada uno de los agentes autónomos (robots) dispuestos en el espacio. Se dibuja la noción de actor en tanto que, se relacionó con la obra a través de una conexión directa con el sistema, mediada por una interfaz no explícita (el cuerpo), la cual se configura en la medida que el actor de manera intuitiva se preguntó por las lógicas del movimiento de las esferas. De ahí que, las actuaciones del actor en el espacio fueron actuaciones performáticas.

Manifestó en la entrevista Mariela Yeregui con relación a la actuación del público lo siguiente:

"El público se metía mucho con la obra, pasaba mucho tiempo con ella. Yo me detuve a ver las reacciones del público algo que me interesaba mucho, y lo que noté es que la gente pasaba mucho tiempo en contacto con la obra. Algunos espectadores se tiraban en el piso, hacia como secciones de relajación. Los chicos se relacionaban de manera intuitiva, en seguida se daban cuenta que estaba pasando, el asombro y la magia era evidente para ellos. El público en síntesis busca relacionarse.” (M. Yeregui, comunicación personal, 17 de junio de 2014).

El público configurado desde la noción de actor, estableció una relación dialógica con el dispositivo robótico puesto en escena. Dispositivo diseñado de manera tal, que era capaz de leer los movimientos corporales o las acciones performáticas que el actor ejecutaba tales como: deambular entre las esferas, interponerse entre ellas, tumbarse en el piso, gestualizar frente a ellas, etc. En este sentido, los movimientos corporales, los desplazamientos y las 
diversas actuaciones que devienen de la relación con los agentes autónomos, alteran el sistema y modifican el devenir de la instalación.

Otro aspecto a considerar, es como se determinó en particular que un solo agente robótico se comportara de manera contradictoria a los demás, al no repelerse de las otras esferas, sino por el contrario, a entrar o intentar entrar en choque cuando algo se le aproximara. La crítica y curadora de arte Valeria González definió la propuesta de Yeregui como un "laboratorio de conducta" (González V. , 2013) Es claro que la movilidad del público modificaba los algoritmos de comportamiento asignados a las esferas, así como los procesos de respuesta los cuales se sucedían en tiempo real. Si bien es cierto que había autonomía en cuanto al movimiento de los robots y sus comportamientos, también es cierto que la tipificación del actor, expandía la realidad interna hacia una realidad externa, en la cual el movimiento propiciaba la metáfora que el concepto "proxemia" propuso en aquel entonces. Se constataron dos realidades a partir de la actuación del público en su rol de actor: una la de un receptor consciente de que puede o no participar del juego y sumergirse en la obra. Y otra, la del actor que es consciente de que con su presencia, actuación, gestualidad y movimientos tiene una influencia activa para el desarrollo de la puesta en escena. Introducir la participación en esta instalación implicó la generación de una gramática lo suficientemente amplia como para que se dieran desarrollos de acuerdo con unas leyes propias, que permitieron la autonomía creativa y expresiva del público en su calidad de actor.

Las educadora Josefina Pasman, en su artículo Arte y nuevas tecnologías ¿nuevos educadores? Afirman con respecto a Proxemia lo siguiente:

"Ante esta escena, el espectador necesitaba un tiempo para recorrer la obra, para "habitar" el espacio, para reconocer la dinámica interactiva. La exploración del espacio muchas veces llevaba a que los espectadores pensaran que las esferas los perseguían. En estas obras se manifiesta una especificidad en el manejo del tiempo, no se plantea la noción de tiempo absoluto, sino al contrario un tiempo que se vive, que depende del observador y, por lo tanto, de la percepción. Es un tiempo subjetivo que relaciona acciones en tiempo real, que pueden ocurrir aquí y ahora, con los modos de relación del cuerpo y el espacio.” (Pasman, 2006)

Actuaciones como las planteadas en el párrafo anterior corroboran la configuración de la noción de actor. Se hacen evidentes rasgos como: la temporalidad, la espacialidad, el 
desarrollo de dinámicas interactivas, la configuración de papeles como el de perseguido o perseguidor y diversas maneras de intercambio, que se suceden en tiempo real entre el cuerpo y el espacio.

En síntesis, Proxemia propuso un dispositivo escénico en el cual cohabitaban robots y humanos. Humanos que específicamente con su presencia y actuación, invadieron el espacio escénico y vivenciaron la instalación. A través de dicha experiencia, se tipificó el rol de actor para el público; no como se lo definiría en marco teatral, sino en el sentido de un performer que con su actuación propicia la activación y desarrollo de la instalación.

La instalación robótica Proxemia fue pionera en el escenario del arte electrónico en Buenos Aires. Al respecto Mariela Yeregui esbozó dicho impacto así:

"La obra se puso en escena en el 2005. Según Laura Buccellato la directora del MAMBA, es la primera obra robótica de Argentina, yo no podría asegurarlo, aunque no me consta que haya habido otras obras robóticas en ese momento. Yo creo que Proxemia fue como tirar una piedra en el estanque, se generó un florecimiento de lo robótico en Argentina, se generó un interés por este asunto. Yo empecé a trabajar con Paula Gaetano que hizo Alexitimia, hubo otra gente que empezó a trabajar como Emiliano Causa y el Grupo Biopus. Fue un puntapié inicial, porque fue una obra de gran visibilidad, en un espacio importante de ese momento como El Espacio de Telefónica consagrado al arte y la tecnología." (M. Yeregui, comunicación personal, 17 de junio de 2014).

La obra con un componente autopoiético e inmersivo, propició un espacio, en el cual se configuraron experiencias que expandieron el papel del público tradicional hacia la noción de actor, como se sustentó en los párrafos anteriores. Desarrolló sistemas de movimiento autónomos para configurar la noción robótica y a su vez marcó un derrotero para el advenimiento de propuestas robóticas en la escena del arte electrónico en Buenos Aires. 


\subsubsection{Propagaciones - instalación robótica - Leo Nuñez}

"Propagaciones es un sistema de autómatas celulares conformado por 50 robots Low-tech, que explora la relación hombre/maquina, la materialidad robótica apropiándose de su diseño electrónico como forma del objeto y la posibilidad de un discurso crítico a partir del uso de la tecnología Low-tech dentro de un paradigma computacional científico.” (Nuñez, 2007)

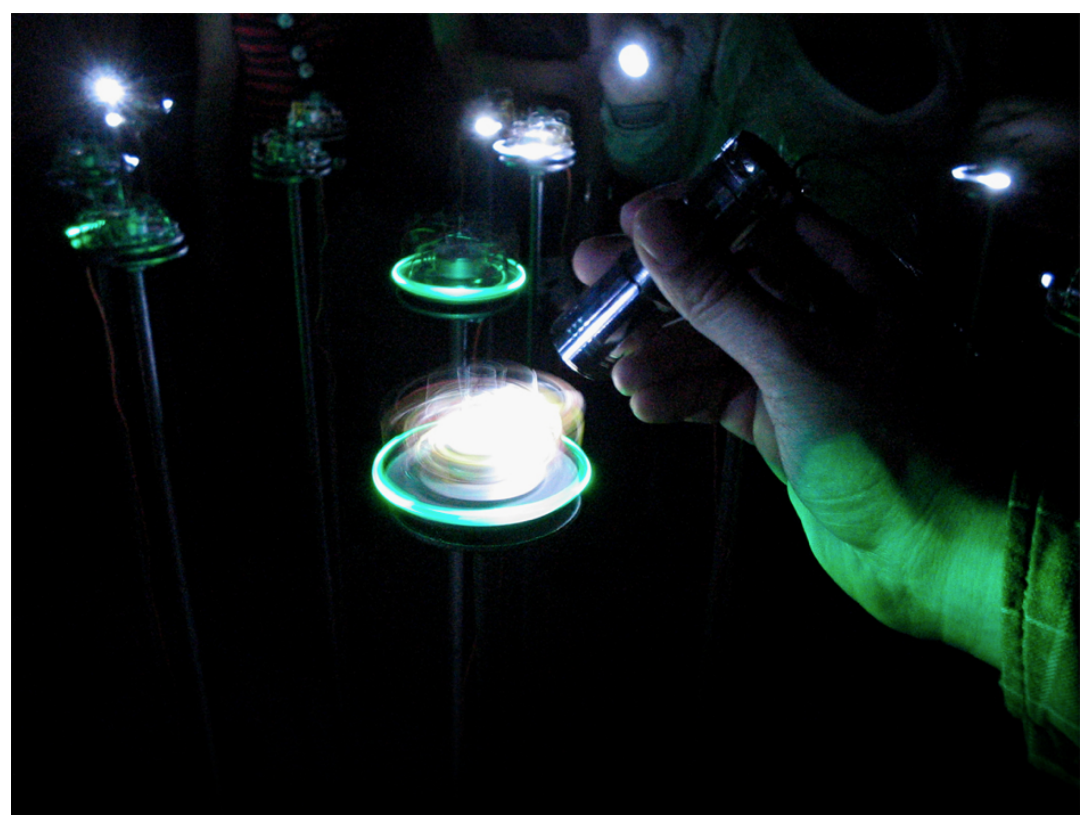

Ilustración 21. Detalle de la instalación. Propagaciones. leo Nuñez.

La obra de Leo Nuñez versó sobre la relación hombre/máquina y el papel que los procesos tecnológicos juegan en nuestra sociedad. Propagaciones giró en torno a las posibilidades de interacción del público como elemento perturbador en su relación con la tecnología. La instalación posibilitó la intervención y la modificación de la obra por parte del público; se trató, como afirmó el artista en la entrevista, de la posibilidad de: "intervenir sistemas complejos a partir de la integración del espectador”. (L. Nuñez, comunicación personal, 19 septiembre de 2014). La obra Investigó acerca de las teorías computacionales en torno a los autómatas celulares, igualmente sobre los sistemas caóticos, su estabilidad y perturbación, así como, en torno a las ideas arquetípicas de vida artificial de John Conway en los años 70. Además de los anteriores ejes investigativos hubo en particular un eje central relacionado con la tecnología low-tech, Leo Nuñez mantuvo un marcado interés por la 
relación desigual que se dio con la tecnología en los países latinoamericanos. De ahí su voluntad creativa de trascender las distancias tecnológicas y permitirse el uso de la tecnología low-tech como una manera de cuestionar dichas relaciones.

Esta obra exploró la posibilidad de crear un sistema de robots basados en las teorías computacionales sobre autómatas celulares. Los robots se diseñaron como objetos independientes en su funcionalidad. Sin embargo, el estado dinámico de los autómatas dependía de los comportamientos de los robots vecinos y del público. El control de los robots dependió del sistema en la propagación de información entre los objetos y de la actuación del público.

Cada autómata se moldeó como una pequeña escultura robótica. La forma del objeto fue moldeada por los distintos componentes que la constituían. Dicha apariencia acentuó una estética funcionalista en tanto no se procuró ocultar el mecanismo, sino por el contrario evidenciarlo y tipificarlo como forma. Cada robot fue construido a partir de tecnología lowtech, lo que busco generar un discurso que se instalara en un contexto de crítica social, para evidenciar la desigualdad en la distribución de la tecnología entre los países del primer mundo y los de Latinoamérica.

La información de texto e imagen recopilada a continuación es una síntesis del video Propagaciones - Leo Nuñez publicado en (Youtube, 2009), el cual hace referencia específica de las distintas etapas al proceso de diseño de la instalación:

1. Definición de la forma del comportamiento de los autómatas celulares (cantidad de emisores y receptores de información de cada autómata celular)

2. Simulación de distintos sistemas y resolución de células que tengas dos entradas y una sola salida.

3. Diseño de circuito electrónico que supla dicha necesidad.

4. Diseño de interfaz lumínica utilizando sensores de luz como receptores de la información y Leds como emisores. Los receptores son DLR resistencias sensibles al contacto con la luz y cambian su valor según las variaciones lumínicas; cuando dicho valor pasa un umbral el robot se activa.

5. A partir de la definición del circuito se hizo el desarrollo pertinente para mecanizarla, teniendo como base un rotor, un eje, y una base para propiciar el movimiento de giro 
del mecanismo. Dicho movimiento está generado por la incorporación de un sistema de escobillas que conducen los impulsos eléctricos.

6. La disposición de esta obra consiste en 10 nodos de cinco robots. Esto genera dos niveles de interacción: un primer nivel entre los robots internos al nodo y un segundo nivel entre los robots de distintos nodos.

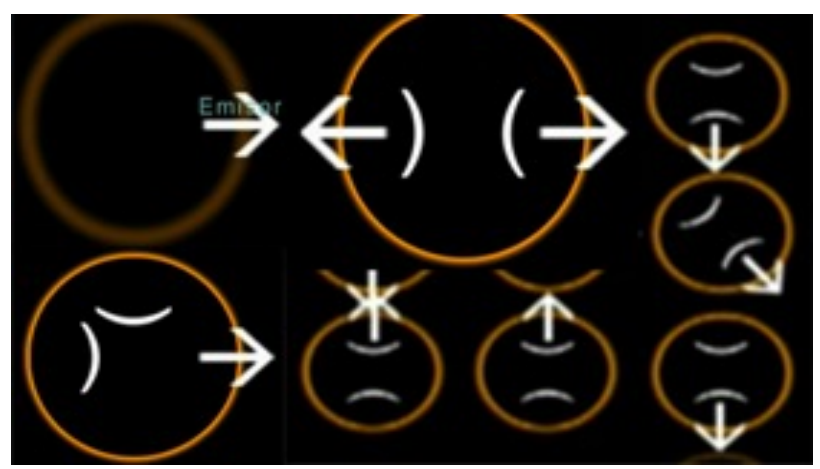

Ilustración 22. Detalle célula. Propagaciones. Leo Nuñez.

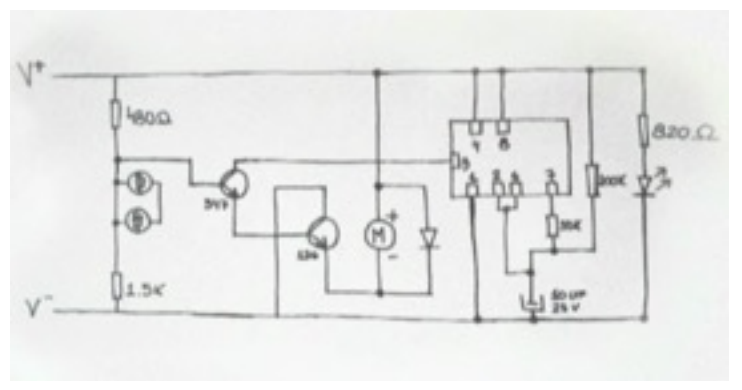

Ilustración 23. Circuito. Propagaciones. Leo Nuñez.

El diseño de la instalación robótica supuso dos niveles de comportamiento:

1. Un primer nivel, el de los autómatas que fueron programados para que actúen entre sí, de acuerdo a unas pautas de luz diseñadas previamente,

2. y un segundo nivel, referido a la participación del público. La actuación del público incidió perturbadoramente sobre la instalación, en la medida que este interactuó con la luz proveniente de su celular. 


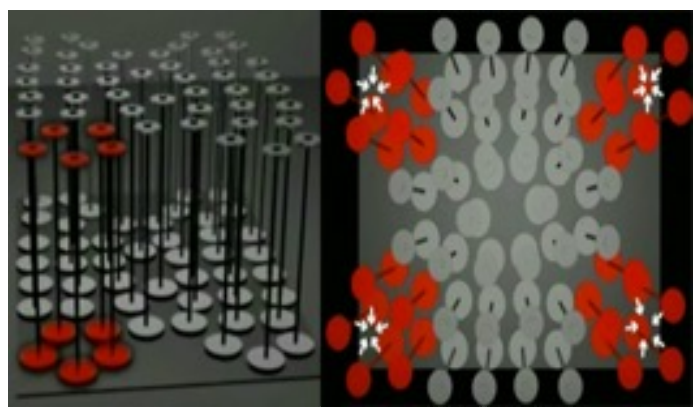

Ilustración 24. Pedestales. Propagaciones. Leo Nuñez.

Si bien es cierto lo anterior, el proceso de interacción con los autómatas se vio mediado por la estabilidad el sistema. Cuando el sistema se equilibra y los autómatas detienen su movimiento rotatorio, la interacción es requerida a través de lo que el artista denomina acción perturbadora. Respecto a la mediación y participación, Leo Nuñez afirmó aspectos interesantes en el sentido de transparentar y desmitificar el proceso interactivo. El público hace construcciones respecto al porque giran los robots sobre el pedestal, él trata de descifrar el mecanismo de rotación, de explicárselo mediante lógicas de su propio comportamiento. Leo Nuñez al respecto puntualizó: "en Propagaciones el rol del espectador es activo y necesario para la evolución del sistema." (L. Nuñez, comunicación personal, 19 septiembre de 2014).

Los agentes o robots de las obras Propagaciones, Proxemia y Espacio Cambiario compartieron en su diseño, el haber sido dotados de comportamientos autónomos de actuación frente a los asistentes a la exposición o frente a otros robots bien fueran esferas o rotores de luz. Al respecto Edward Couchot en su libro La tecnología en el arte: De la fotografía a la realidad virtual, haciendo referencia al papel del espectador y su relación con la obra interactiva, planteó una diferenciación entre interacción externa e interacción interna. La externa hacía referencia a la relación humano-máquina por medio de la interfaz y la interna hacía referencia a los procesos comunicativos entre los propios objetos que constituyen la instalación, situación que se presentó en las instalaciones robóticas anunciadas. (Couchot, 1998). Dichas interacciones externas e internas se evidenciaron en las obras robóticas tratadas: en Proxemia por los movimientos corporales, en Propagaciones por la acción de la luz o en Espacio Cambiario por datos provenientes de la red.

El hecho de que la actuación fuera necesaria para la evolución del sistema en la instalación, estableció una relación dialógica entre los autómatas y los espectadores. La mediación dada por la interfaz lumínica, permitió la interacción con la obra, así como la de 
los autómatas entre ellos mismos. Propagaciones posibilitó la integración de la obra con el contexto, gracias a su permeabilidad y estructura, lo que posibilitó el acceso, desarrollo y evolución de la misma. Por lo tanto, se produjo un distanciamiento del modelo de obra tradicional.

La actuación de los participantes se produjo mediante acciones de orden lumínico, dado que la interfaz o puente de comunicación fue a través la luz. Queda claro que no existió un contacto directo con la corporalidad de la obra robótica, como en el caso de Alexitimia. No hubo ni una membrana ni un mecanismo de contacto que intermediara entre el sistema y el receptor. La anterior situación, determinó que la noción del rol tradicional como el que asiste y participa del espacio instalativo se debilitara o desvaneciera. Por el contrario, la experiencia interactiva diseñada favoreció el surgimiento de una actuación por parte del participante en cuestión. Actuación que se manifestó a través del movimiento y la circulación en torno a la obra, así como por la acción perturbadora que de manera consciente, el actor constituido ejecutó al establecer un puente dialógico a través de la luz de sus celulares o por otros medios. Se configuró entonces, una actuación que expandió el rol hacia la noción de actor. El límite o delimitación entre el receptor y la obra se alteró, al respecto Silvina Valesini dijo: “Cuando esa delimitación se altera, para posibilitar la interacción de un espectador que pueda llegar a modificar el flujo de la acción, este pierde su condición de tal para asumir el rol de actor, borrando de este modo el límite entre lo real y lo ficcional.” (Valesini, 2014, pág. 57) Es así como la actuación performática motivada por la instalación o la necesidad de interacción permitió el intercambio dialógico con el dispositivo. No hubo una interfaz explicita en la obra Propagaciones. La mediación se produjo a través de sensores lumínicos que estaban dotados de la capacidad de leer información ondular (la luz). Por lo tanto, la actuación o accionar del actor por medio de haces de luz provenientes de los aparatos celulares o linternas modificaba el estado de latencia potencial de la obra. Leo Nuñez preguntado en la entrevista sobre la interacción del público con los objetos robóticos, la interfaz lumínica y el concepto de la obra expresó:

"Si, de hecho, esta obra estaba programada para detectar niveles de luz con mi celular del momento, es un poco eso, las teorías sobre autómatas celulares en las cuales me baso para hacer la obra parten del concepto de redes neuronales muy básicas los cuales en los años 60 eran pensados como sistemas cerrados, hoy en día 
la ciencia es mucho más abierta y logra mucho más. En realidad, los objetos se comunican entre ellos con luz, y se establecen suposiciones en relación a su vecindad, dependiendo como estén los vecinos cada uno se mueve o se detiene. En algún momento el sistema se vuelve estable y quedan todos detenidos en una misma posición en este caso se apagan hasta que alguien del público planta una nueva semilla con la luz de celular y el sistema se activa de nuevo. Eso es lo que estoy haciendo, darle al sistema y al espectador la nueva posibilidad de perturbarlo, de modificarlo de alterarlo.” (L. Nuñez, comunicación personal, 19 septiembre de 2014).

La actuación del actor, en el sentido que Silvina Valesini expresó, es componente esencial y a la vez complementario en el entramado del diseño propuesto por el artista. La participación perturbadora de dicho actor con un haz de luz desactivó el estado de equilibrio y quietud en que se encontraba la instalación en un momento determinado de su fluir.

Propagaciones con su atractivo lumínico, atmósferas claro oscuras y movimientos vertiginosos y aleatorios configuró la noción de actor. La interacción que se le propuso al público fue actuar con la luz de sus celulares u otro objeto que emitiera luz, en una atmosfera oscura especialmente diseñada para ello. En el espacio de la obra se organizaron cincuenta robots en una matriz de filas y columnas, a la cual se podía acceder por parte del actor desde el perímetro de la misma. La participación de los actores se daba de manera aleatoria y simultanea desde los diferentes costados del espacio instalativo. Actuación que incidía perturbadoramente en el comportamiento de los robots y que aleatoriamente también en ciertos momentos alcanzaba puntos de equilibrio y quietud. Los participantes directos de la instalación, bien sea por contagio o por discernimiento terminaban siendo conscientes de que su presencia y actuación tenía una influencia activa en la obra.

Con relación a que tanta invención tecnológica pudo proponer la obra en su primera exhibición Leo Nuñez dijo:

"Considero que de hecho Propagaciones ninguna. La idea era trabajar con tecnología ya existentes en torno a los autómatas celulares y utilizar algoritmos que ya se compartían en red, quizás para los espectadores y el medio sea algo novedoso sin embargo técnicamente hablando estas tecnologías ya existían y se utilizaban en el mundo.” (L. Nuñez, comunicación personal, 19 septiembre de 2014). 
En cuanto a la relación entre el desarrollo tecnológico y la temática de la obra Leo Nuñez dijo finalmente:

"Muchas de las obras de principios del 2000 quizás hablaban de temas ajenos a nosotros como vida artificial, ADN, cosas muy grandes que las personas del común están muy lejos de eso, nuestra sociedad ni se fija en eso porque tiene otras problemáticas, como la falta de servicios públicos como agua, luz, alcantarillado. Así es como la Argentina empieza poco a poco a tocar temáticas más propias que ajenas." (L. Nuñez, comunicación personal, 19 septiembre de 2014). 


\subsubsection{Espacio cambiario - instalación robótica - Leo Nuñez}

"Espacio cambiario es una instalación robótica que reflexiona sobre la dinámica del Espacio cambiario, apropiándose de sus flujos de información para evidenciar la progresión del estado económico de nuestra sociedad y materializando las pujas virtuales de las divisas en una colonia de robots, los cuales incorporan la territorialidad como forma de comportamiento en un espacio físico real. Los robots estarán divididos en tres grupos por color. Cada color representará a una divisa: los blancos al Peso, los verdes al Dólar y los azules al Euro. Estos se comportarán territorialmente como animales cuidando su espacio, tratando de conquistar nuevos y echando a los invasores, pero el nivel de agresividad de estos variará en relación con la cotización de la moneda que representen en el Espacio cambiario.” (Nuñez, 2010)

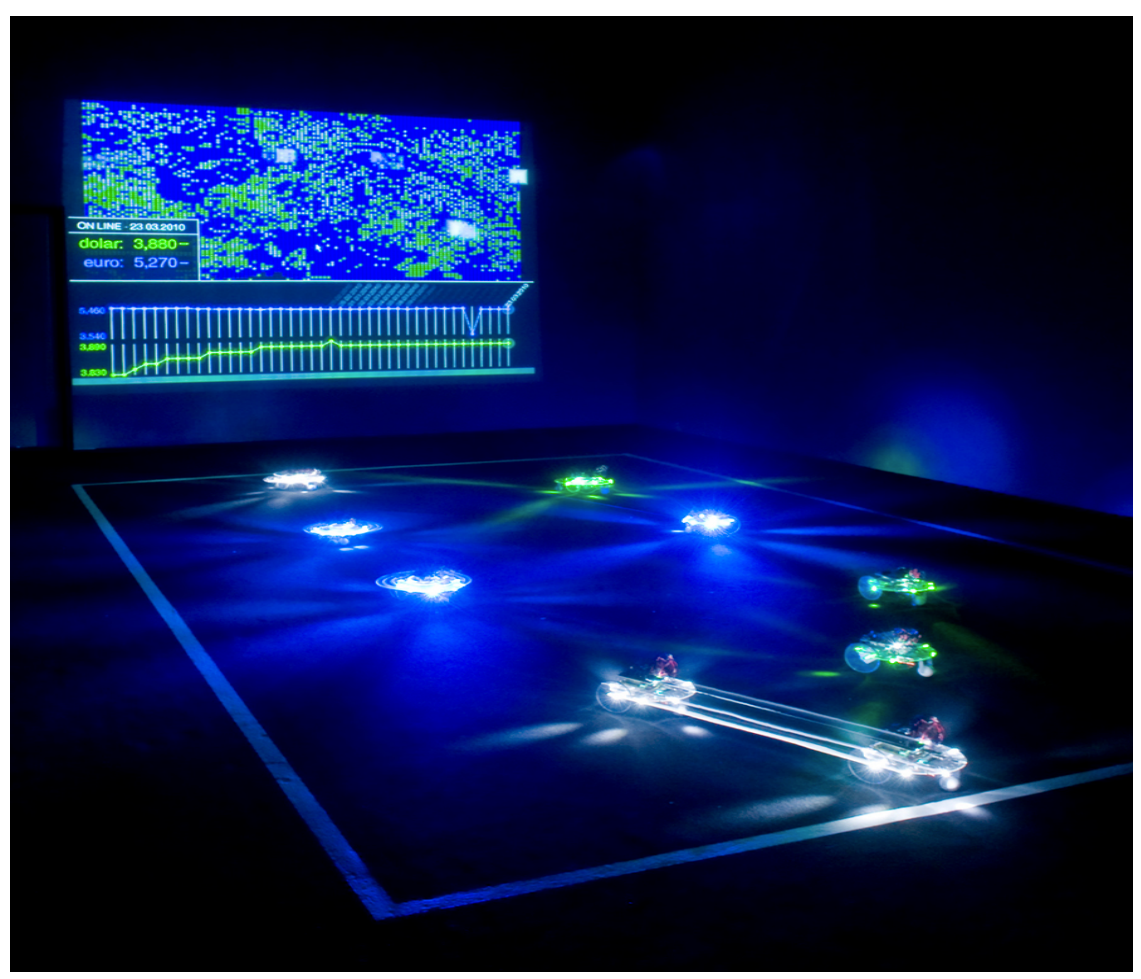

Ilustración 25. Espacio cambiario Instalación Interactiva. Leo Nuñez.

El artista Leo Nuñez, planteó una obra robótica, la cual se instaló en un espacio en penumbras, que hizo las veces de ecosistema. Ambiente en el cual una comunidad de robots transitaba emitiendo destellos de luz. La obra en su diseño portó un sistema computacional 
basado en un software, el cual regulaba los niveles de agresividad o comportamiento de las pequeñas máquinas que la constituían.

La obra Espacio Cambiario en su diseño no presupuestó la posibilidad de un público que interactuara con la instalación para su activación. El comportamiento de los robots estaba determinado por las variaciones o fluctuaciones del cambio de las monedas en el Espacio cambiario. Cabría entonces preguntarse por la relación del público con la obra. Al respecto el artista Leo Nuñez explicó:

"Espacio cambiario, es solo una visualización de datos, a través de comportamientos. En este caso el público puede visualizar el comportamiento del mercado por ejemplo del dólar a través de la visualización de las luces u objetos verdes, más que ver el dato preciso es la posibilidad de ver la disputa del espacio por parte de los robots.” (L. Nuñez, comunicación personal, 19 septiembre de 2014).

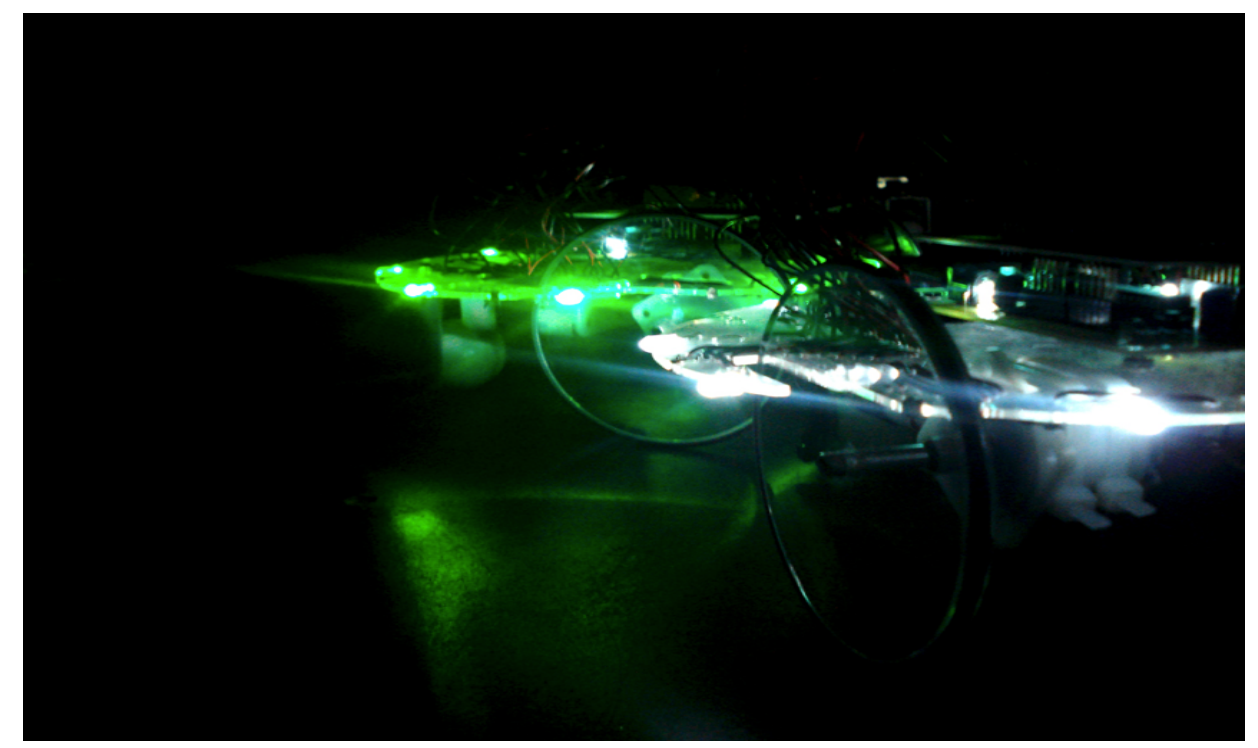

Ilustración 26. Detalle lumínico de Autómata celular.

La intencionalidad del artista como él mismo lo manifestó, fue generar un espacio en el cual se escenificaran a través de comportamientos, las disputas territoriales entre los robots de la instalación. Disputas a su vez que se nutrían de los datos recolectados en la Internet en relación con las fluctuaciones de las monedas. La no-localización fue un fenómeno presente en esta instalación. La data que alimentaba el sistema provenía de múltiples lugares a la vez, los cuales se interconectaban a través de la Web. 
En esta instalación el rol del público se configuró como el de un observador. La relación que se estableció entre él y la obra, fue por medio de las visualizaciones de las pantallas dispuestas para tal fin o a través de los comportamientos de los robots; relación que se desarrolló en un plano netamente subjetivo. De hecho, dicho acercamiento subjetivo hacia la instalación, se veía afectado por las lecturas, interpretaciones o suposiciones que él hacía. Observaciones y suposiciones que carecían de sustrato, en tanto los comportamientos de los robots eran el producto de la programación del sistema y no de la movilidad, actuación o intencionalidad del público. Al respecto Leo Nuñez dijo acerca del comportamiento del público con relación con las disputas territoriales de los robots lo siguiente:

"El público intenta interactuar con el objeto, se acerca a los robots, se introduce en su espacio, le asigna características que el objeto no tiene, por ejemplo, si el objeto se dirige hacia una persona o gira, el público dice ¡ah!, me vio o me detectó. El público empieza a imaginar y darle un valor interactivo al objeto, pero en realidad el objeto no lo tiene. Para mi resulta divertido observar al espectador, el cual espera una obra interactiva, se comporta frente a los robots como si lo fuera, pero la verdad es que no la obra no está planteada como instalación interactiva sino como instalación robótica.” (L. Nuñez, comunicación personal, 19 septiembre de 2014).

La participación se activó debido a la curiosidad y el deseo de explicarse el comportamiento de los objetos en el espacio. La actitud de observación por parte del público fue dinámica, en tanto que este interactuaba con los robots desde su subjetividad e intencionalidad. Sin embargo, la relación dialógica no se estableció con la instalación, dado que, el comportamiento del espectador, su movilidad en el espacio no alteraba de ninguna manera el programa que gobernaba los comportamientos de los robots. Dicha relación dialógica tan solo sucedía en el imaginario de los presentes. En el catálogo de la exhibición A. García citó a Leo Nuñez cuando afirmó respecto del público:

“Al espectador humano de esta obra, entonces, le estaría dada solo la posibilidad de observar la escena desde afuera. La finalidad última, entiendo, sería tal vez invertir, como si se tratara un guante, la relación entre autor, espectador, y contexto de producción, lugar simbólico donde toda obra negocia su producción de sentido con el afuera del arte." (García A. , 2009) 
Sin ser la intensión del artista compartir el control de la instalación robótica con el público, este participó con la ilusión de tener cierto control sobre el comportamiento y devenir de los robots en escena. La ilusión del control se instauró en la dualidad existente entre controlado y controlador. Se generó o se expandió esta ilusión, hacia la interrelación o juego de poder que se daba entre ambos. En este caso se puso en evidencia el peso del contexto como generador de la ilusión de interacción que se experimentaba en el espacio expositivo.

De acuerdo con las anotaciones anteriores, se podría afirmar entonces que la noción de observador21 se configuró en esta obra, en síntesis, la tecnología en el caso aquí tratado, fue parte fundamental de la investigación del artista, quien desde su postura crítica frente al fenómeno social, acotó que las máquinas son herramientas al servicio de un constructo conceptual que involucra al público en tanto que este visualiza datos que pretenden establecer lógicas de comportamiento para los robots, las cuales es claro, son inexistentes dada la autonomía de cada robots.

En las obras Propagaciones y Espacio cambiario de autoría de Leo Nuñez se presentaron diferencias en cuanto al manejo espacial de la instalación. Al respecto el artista estableció claramente la comparación y diferenciación del fenómeno espacial entre ambas al afirmar:

"La disposición de los objetos está definida grupalmente. Los objetos reaccionan en cascada y luego se puede observar la relación de los grupos hacia fuera. En la obra Propagaciones, no hay una discusión de espacios entre los objetos. En Espacio cambiario lo que hacemos es transportar la información inmaterial de los valores del mercado a una discusión del espacio real por parte de los objetos, allí se puede observar una reconfiguración del espacio, y como una idea de re-significación del espacio expositivo en cuanto estoy viviendo espacialmente lo que a nivel de datos

21 “...para efectos del análisis de las instalaciones interactivas y robóticas aquí tratadas se dará tratamiento de observador al público, en el caso de aquellas instalaciones en que el dispositivo electrónico o el diseño del artista no interactúa con el público, y viceversa en que la presencia y participación del público no activa ni determina el devenir abierto de la instalación. Siendo el caso, el de aquellas instalaciones que reciben inputs desde bases de datos estadísticos, las cuales se activan y establecen relaciones dialógicas con la información que devienen de dichas bases de datos o de la Internet." 
del mercado no puedo materializar. En Propagaciones de entrada existen unos requerimientos espaciales iniciales, pero el espacio sigue siendo el mismo durante la exhibición.” (L. Nuñez, comunicación personal, 19 septiembre de 2014).

En este tipo de instalaciones robóticas la circulación del público por el espacio instalativo generó la posibilidad de interacción, en tanto que, sensores de movimiento fueron incorporados en las obras electrónicas, no siendo este el caso en la obra Espacio cambiario. Situación que, de una u otra forma, perfiló en la mente del público la idea de que con su movilidad era posible afectar las obras, interactuar con ellas y poseer parte del control de lo que acaecía en la escena.

Las obras Espacio cambiario y Propagaciones del artista Leo Nuñez, fueron producciones que desarrollaron un lenguaje nuevo al concebir la tecnología no solo como medio sino como una posibilidad matérica para el hecho estético. La indagación por el papel del público y su capacidad de perturbación en el comportamiento o no de los sistemas complejos, en cierta medida fue novedosa en la escena del Arte electrónico de aquella época en Buenos Aires. Fueron obras que se contextualizaron en lo que se denominó low tech. Finalmente, Leo Nuñez consideró estas instalaciones como sistemas abiertos al afirmar: "Uno puede acercarse a una obra mía, copiar el circuito e ir a casa y hacerlo, no necesita más que eso." (L. Nuñez, comunicación personal, 19 septiembre de 2014). 


\subsubsection{Alexitimia - instalación Robótica - Paula Gaetano}

Alexitimia instalación robótica interactiva, fue propuesta como otro agente autónomo, enmarcado en los conceptos de comunicación no-verbal, en oposición a los agentes robóticos de Proxemia. La instalación robótica Alexitimia fue solo un objeto robótico que habitó el espacio expositivo, silente, inmóvil y carente de cualquier artilugio que hiciera evidente función alguna. Las anteriores características contrastaron con las esferas rodantes de la obra Proxemia, los cuales deambulaban por el espacio autónomamente y estaban dotadas de diversos comportamientos programados.

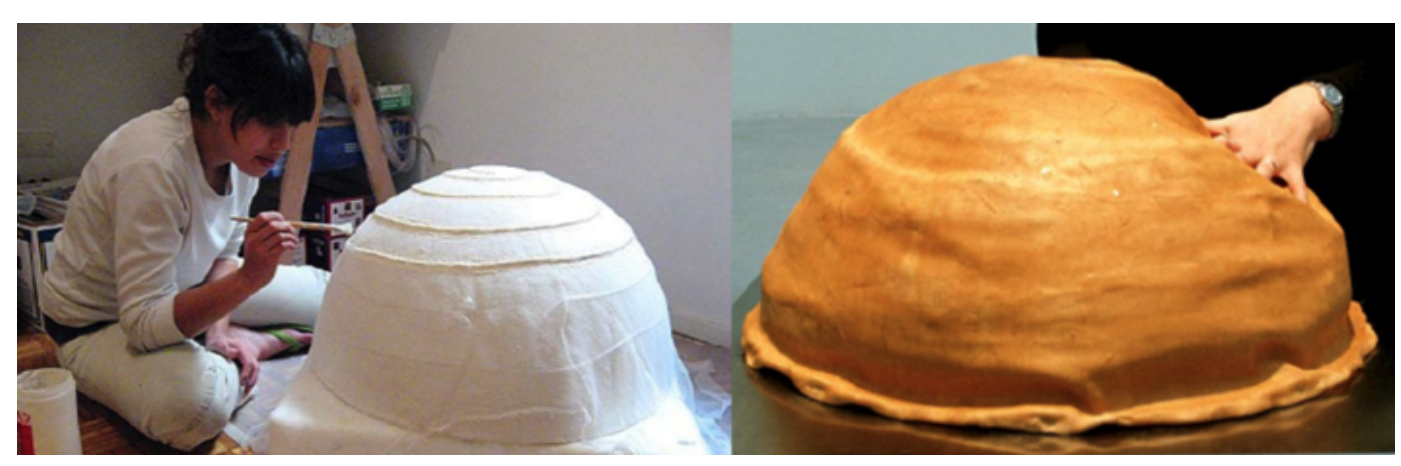

Ilustración 27. Alexitimia - Instalación Robótica 2005.

Describió de la siguiente manera Paula Gaetano la instalación robótica en cuestión:

"Alexitimia es un robot con forma y comportamiento atípicos. Es un agente autónomo robótico cuyo comportamiento fundamental reside en su capacidad de tener un "lenguaje” puramente corporal. En esta pieza, el 'cuerpo' del robot ocupa un lugar central y en oposición a una "inteligencia artificial", plantea una "corporalidad artificial". Una corporalidad artificial, que funciona principalmente como interfaz de la pieza, como su materialidad y su forma. Este agente alexitímico, a diferencia de la mayoría de los robots, exhibe un comportamiento ambiguo e inusual, pues no parece ser una poderosa máquina con un software igualmente poderoso construido sobre un cuerpo móvil y diestro capaz de actuar 'racionalmente' con relación a sus percepciones del mundo que lo rodea. Por el contrario, es un robot construido sin una clara utilidad, sin una funcionalidad y por lo tanto, sin específicas motivaciones o metas a alcanzar. Con una apariencia orgánica, realizada con materiales blandos y flexibles, este agente robótico fue diseñado como una semiesfera irregular que 
permanece agazapado sobre el piso de la sala de exhibición. Este robot, no puede movilizarse por el espacio, no puede ver, no puede emitir sonidos ni detectar voces; sin embargo, puede interactuar con los espectadores a través de su cuerpo. Intentando poner de manifiesto una visión holística de la dicotomía hardware/software que parece ser el eco de la dualidad cartesiana, previa y más primitiva, de mente/cuerpo; este robot, despojado de un aspecto antropomórfico, solo tiene un modo de percepción táctil. Así, utilizando su piel artificial como interfaz, el cuerpo del robot comienza a transpirar ante el tacto/contacto de un espectador." (Gaetano, 2005, pág. 30)

La instalación robótica en mención surge en torno a la posibilidad de crear un cuerpo netamente artificial. Lo anterior, llevó a la artista a investigar sobre robótica y el concepto de inteligencia artificial, lo que le permitió desarrollar la propuesta Alexitimia. En esta obra, la interfaz se propuso como una corporalidad artificial en oposición a la idea de inteligencia artificial. La investigación bordea estas dos clases de artificialidad, permitiendo la posibilidad de lo que la artista denominó una "estética del comportamiento". En el catálogo de la muestra Paula Gaetano expresó dicha indagación así: “...explorar estéticamente el comportamiento corporal de una máquina y el dialogo entre esa máquina y un espectador." (Gaetano, 2005, pág. 31)

La estructura de la obra y su mecanismo de funcionamiento operó con base en sensores de presión incorporados en la piel de látex del objeto. Estos sensores transmitían el estímulo a un micro controlador, el cual activaba el proceso de secreción. Bombas de agua inyectaban desde los conductos internos agua por los orificios distribuidos en la superficie de la piel del robot. De esta manera el robot simulaba el proceso fisiológico de la transpiración. Sin embargo, el micro controlador no respondía a algoritmos sofisticados que presumieran de cientificidad o de la capacidad de una inteligencia artificial. Las reacciones más complejas relacionadas con este trabajo se observaron en la relación que se establecía entre el público y la obra. Su dimensión táctil creaba un vínculo muy íntimo con el público participante. El hecho del robot de sudar a partir del contacto, permitió a la artista materializar la metáfora de que el robot estaba reaccionando al contacto de un alguien afectivamente. Como se observa, el diseño que sostiene la obra es un sistema simple, casi lineal. El input que provoca la activación del sistema, es la presión táctil ejercida por el público sobre la membrana/interfaz, a lo cual, el sistema responde con la activación de los mecanismos que 
generan la eyección de agua. Se configura entonces una relación entre el objeto y el público mediada por una membrana que opera como interfaz explícita. La interacción resultante convoca la metáfora comunicacional entre el robot y el público.

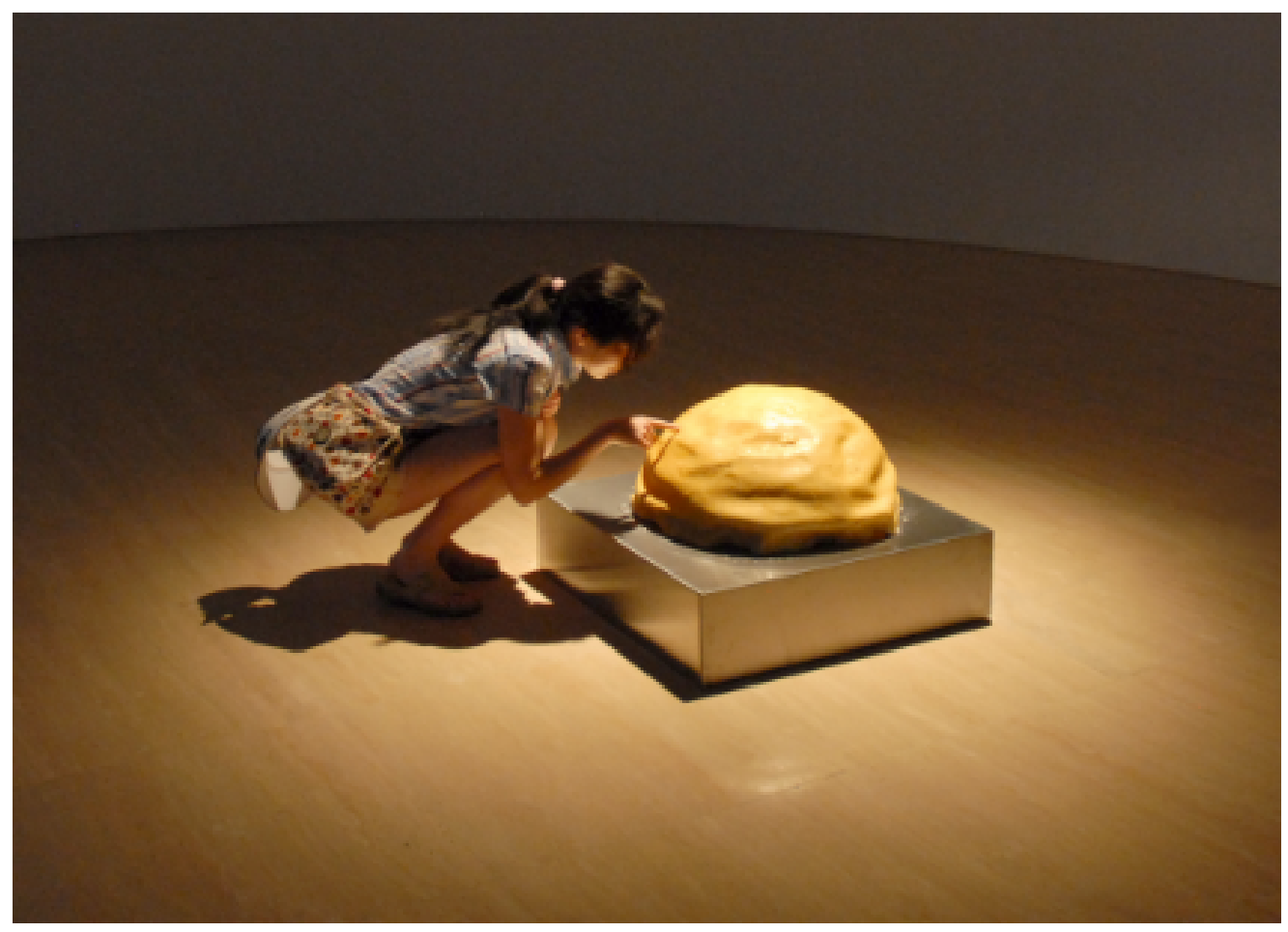

Ilustración 28. Alexitimia - Instalación Robótica 2006.

La obra se completó, cuando se dio la interacción entre el público y el robot. Respecto a las obras de arte interactivas Rodrigo Alonso dijo. "Pocas veces se dan instrucciones sobre las formas de uso de las obras interactivas;" (Alonso, 2005) en el caso de Alexitimia no hubo ninguna nota de programa que anunciara la obra o el mecanismo diseñado. El contacto inicial del público con la obra, ocurría a nivel del contacto visual. Al respecto conceptuó la artista: “...yo nunca explico, hay un catálogo donde se da algún tipo de explicación, hay un murmullo en el ambiente que dice que la obra hay que tocarla, pero yo no soy lo suficientemente explicita, es desde ahí como me interesa el espectador." (P. Gaetano, comunicación personal, 6 diciembre de 2014). Para que la propuesta de interacción que está oculta se sucediera, se requería que alguien del público entrara en contacto con el robot, momento en el cual la interacción comenzaba a fluir. La relación de contacto dadas las dimensiones del robot fue casi individual. El tiempo de contacto estuvo mediado por la duración de la sudoración, o sea el tiempo que el robot requería para que fueran evidentes las gotas que lo simulaban. La artista Paula Gaetano expresó: 
"En Alexitimia la interacción está justificada porque me interesaba generar un diálogo corporal entre una máquina y un espectador, un diálogo entre dos tipos de cuerpos que fuera inevitable para las dos partes, por eso el sentido del tacto; ya que tiene un tipo especial de proximidad. Cuando alguien toca, la experiencia es total e inevitablemente mutua. En Alexitimia, la obra existe antes de que el público interactúe, diría que existe como una escultura, o como un robot inmóvil, y en ese sentido, no es una clásica obra interactiva. Antes de la interacción, hay en esta obra un momento de contemplación más tradicional" (Molas, 2005)

Sobre el dialogo máquina-público, la artista expresó: "Es un dialogo no reactivo, sino emotivo; no racional, sino sensible, un diálogo entre dos tipos de cuerpos, un dialogo corporal.” (Gaetano, 2005, pág. 31) La interacción del público con esta piel, sugería una forma de reciprocidad: yo toco y soy tocado al mismo tiempo. Esta interacción se basó en los sentidos del tacto y de la vista. El primer contacto con la instalación fue a través de la vista, luego vino la palpación para revelar lo que el ojo no podía ver: el interior de esta forma cerrada y su sensibilidad. Esta capacidad de ser y reaccionar a la palpación, fue traducida por el robot a través de la secreción que interactuaba con el tacto y la vista del público. Percibimos un síntoma (el sudor) que connotaba la sensación de que el robot había sido afectado por el contacto del público. Desde la perspectiva de la artista se afirmó en la entrevista con relación al público: "El espectador completa la obra, no creo en el artista aislado, esta es una obra interactiva por lo tanto contempla otro que se va a relacionar con la obra. Para mí el espectador está en la construcción básica de la obra, es una condición sine qua non. Cómo piensa el espectador o como se relaciona con la obra es otra cosa." (P. Gaetano, comunicación personal, 6 diciembre de 2014).

Alexitimia fue una obra en la cual la participación del público sucedió en dos planos: uno visual distante, otro a nivel táctil. Como resultado del comportamiento táctil se dio una interacción débil, en tanto este fue un mecanismo sencillo de input (tacto) output(sudoración). Se observó una relación dialógica entre el público y el robot. Relación silenciosa a través del intercambio de información propiciada por sensores, que no generaban bucles o complejidades en el funcionamiento del algoritmo.

La interacción del público con esta obra se produjo en dos niveles: 
1. A nivel distanciado se enmarcó en la relación tradicional del espectador con la obra. Relación pasiva, como la del que asiste a observar una escultura.

2. De igual manera la noción de interactor se configuró, en la relación que se produjo entre público y robot a través de la interfaz/piel por medio del contacto directo. La presión ejercida en últimas fue el hecho que activaba la obra.

La obra entonces produjo una resignificación en el papel del espectador, en tanto este, dadas las características e intención de la artista, se confrontaba con la obra y asumía un papel activo De ahí que el objeto tuvo la suficiente fuerza, misterio y atractivo estético, para atraer e invitar al público a preguntarse de que forma o manera podría interactuar con dicho robot.

En síntesis, la obra propició una relación dialógica, que supuso la participación de un espectador a nivel físico directo con una interfaz explícita. A pesar que el solo hecho de ingresar en el espacio instalativo no activaba la obra, esta se activaba en el contacto directo con la piel del robot. La noción de interactor logró configurarse en la medida que los procesos potenciales diseñados por la artista se activaban por la intervención directa.

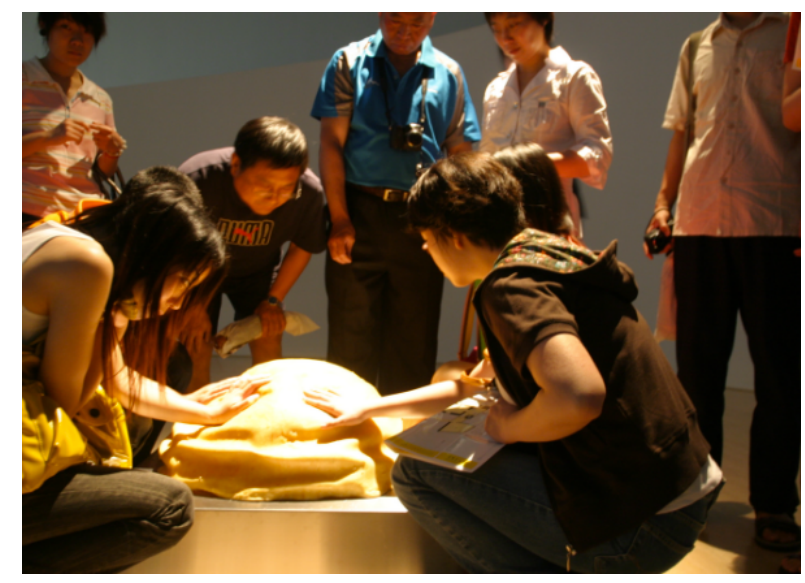

Ilustración 29. Alexitimia 2007.

Esta instalación robótica, al explorar la variable del tacto y conectarla con la sudoración o el componente de lo húmedo entre una piel humana y otra artificial, trajo novedad en el escenario del arte electrónico en Buenos Aires. Paula Gaetano lo expresó en la entrevista así: “...me quedó evidente que la obra era innovativa, que planteaba algún tipo de innovación con relación a la obra de arte interactivo desde otro lugar, un lugar más corporal, más íntimo”. (P. Gaetano, comunicación personal, 6 diciembre de 2014). 


\subsubsection{Generación de Conciencia I, Instalación Robótica. Daniel Álvarez Olmedo,}

\section{Diego Díez, Guido Villar}

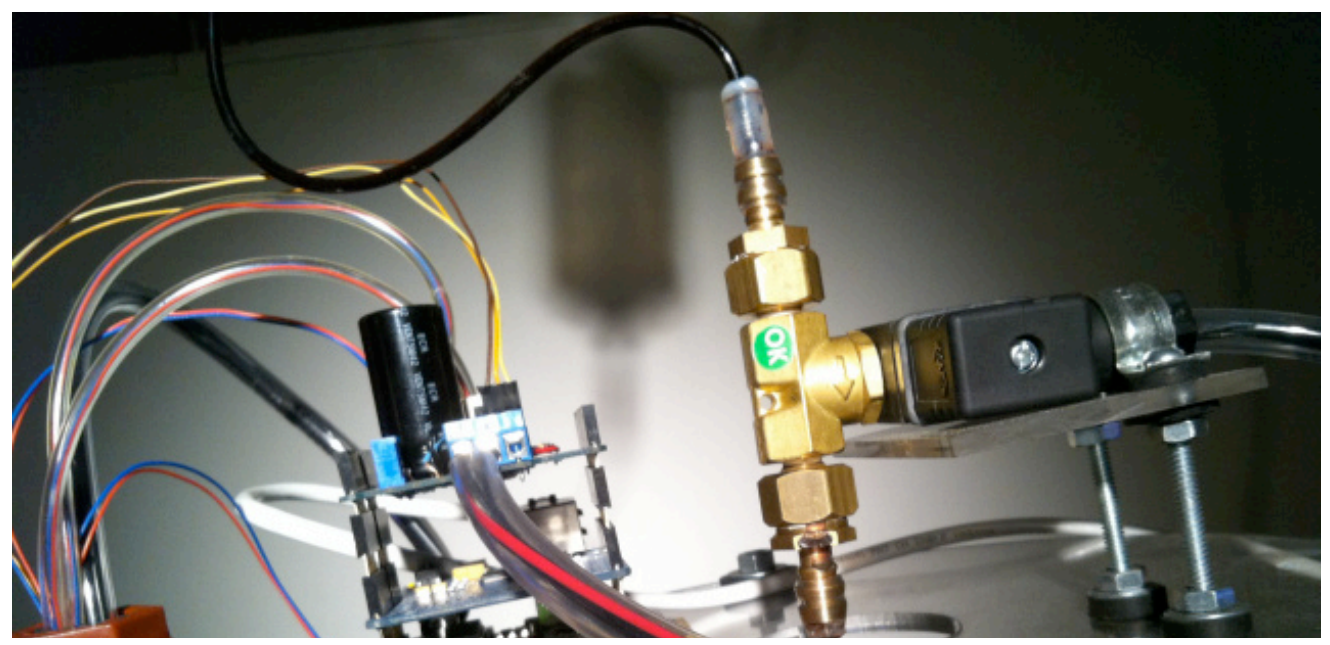

Ilustración 30. Detalle de la instalación.

"Es una instalación robótica que toma datos de la Tasa de mortalidad por mil habitantes de la población total del país desde 1980 hasta el 2007. La interfaz procesa y controla los datos a través de microcontroladores activando el sistema mecánico, modificando el actuar del objeto real y físico que posee una forma de suero de hospital que contiene en su interior un líquido de color rojo que representa la sangre de los muertos del período mencionado. Con un dispositivo compuesto por una electroválvula de apertura y cierre, limita mediante un goteo, el pasaje de líquido a un recipiente que contiene agua con micro-organismos vivos. Estas bacterias se aglutinan alrededor de las gotas que caen devorando su composición. El objeto está dotado de autonomía y realiza sus cálculos sobre la información inicial suministrada por la estadística, en los años de mayor mortalidad el dispositivo goteará más que en los años de menor mortalidad. El líquido que gotea se diluirá en menor y mayor medida de acuerdo al accionar de los micro-organismos, proceso que será filmado y visualizado en video en una pantalla LCD." (Álvarez D. , 2010)

Tras del proyecto de instalación robótica, se observó un proceso minucioso el cual relacionó el fenómeno de la mortalidad a nivel estadístico, con el componente social del 
mismo y el impacto que dicha relación generó en el entorno especifico de la Argentina. Respecto al carácter investigativo del proyecto el artista amplió:

"Nosotros nos consideramos artistas investigadores, no es la típica exposición en sí de la obra terminada, nos interesa también lo previo, lo que sucede antes de la obra, todo ese proceso está en display, como lo armamos, el proceso de conceptualización de la obra, es algo muy fuerte como para dejarlo de lado, más allá de la ficha técnica donde se explica de lo que se trata la obra. Para mí la obra es el disparador, ¿querés saber más? Ahí está la Web, ahí está el LCD que te explica cómo funciona y que significa cada cosa." (D. Álvarez, comunicación personal, 23 de septiembre de 2014).

La obra para su construcción se fundamentó en la utilización de un mecanismo algorítmico de interacción de información interna. En este caso, se relacionaron datos estadísticos de mortalidad, con el propósito de interpretarlos algorítmicamente y traducirlos mediante el fenómeno físico del goteo a través de la manipulación de una bomba dispuesta para tal fin. En este sentido, esta obra se emparentó con la obra Espacio Cambiario, en tanto ambas utilizaron datos de bases de datos externas para ser traducidos autónomamente y provocar comportamientos específicos en el sistema que las gobierna.

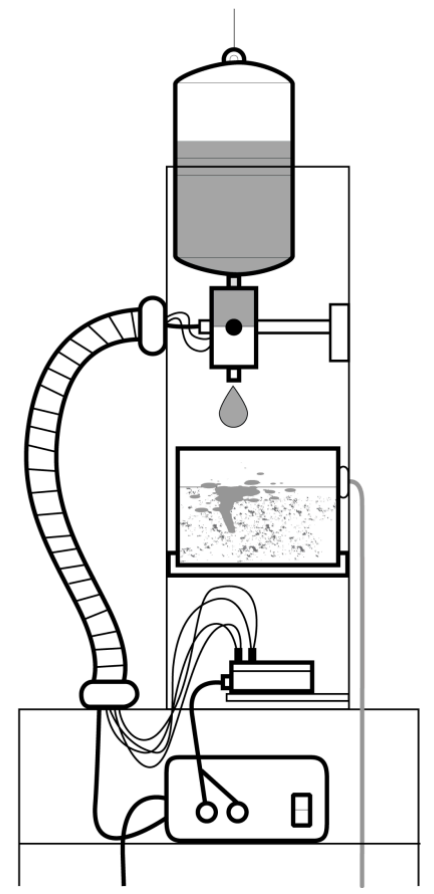

Ilustración 31. Esquema detalle instalación. 
Generación de Conciencia I se sirvió de la tecnología electrónica para expresar un conjunto de ideas relacionadas con una problemática social específica. Logró visualizar los datos mediante un mecanismo de goteo y vibración, para así generar una interacción física con el público a través de una manilla vibratoria, la cual se encontraba disponible en el espacio instalativo.

Con relación a los procesos y la metodología de producción, Daniel Álvarez puntualizó:

"La obra se plantea con varios estadios y varios módulos. La primera etapa es con lo que nosotros llamamos el estudio y la investigación del objeto que nosotros queremos tratar en términos de conocimiento. Con base en la investigación previa, una vez lo tenemos, entonces formulamos el proyecto, o sea que han transcurrido más de tres meses para llegar al punto de formular el proyecto. Una vez que lo tenemos formulado generamos lo que es el "paper" con la documentación pertinente, presupuesto, etapas de trabajo, del equipamiento que necesitamos, que tipo de personas y perfiles vamos a trabajar, químicos, biólogos, ingenieros, después nosotros entramos en el desarrollo, y por último viene la exposición y los procesos de difusión. Intentamos siempre trabajar con un tronco, con una idea troncal que después la podemos variar un poco entre las ramas, pero siempre mantenemos la idea principal.” (D. Álvarez, comunicación personal, 23 de septiembre de 2014). 


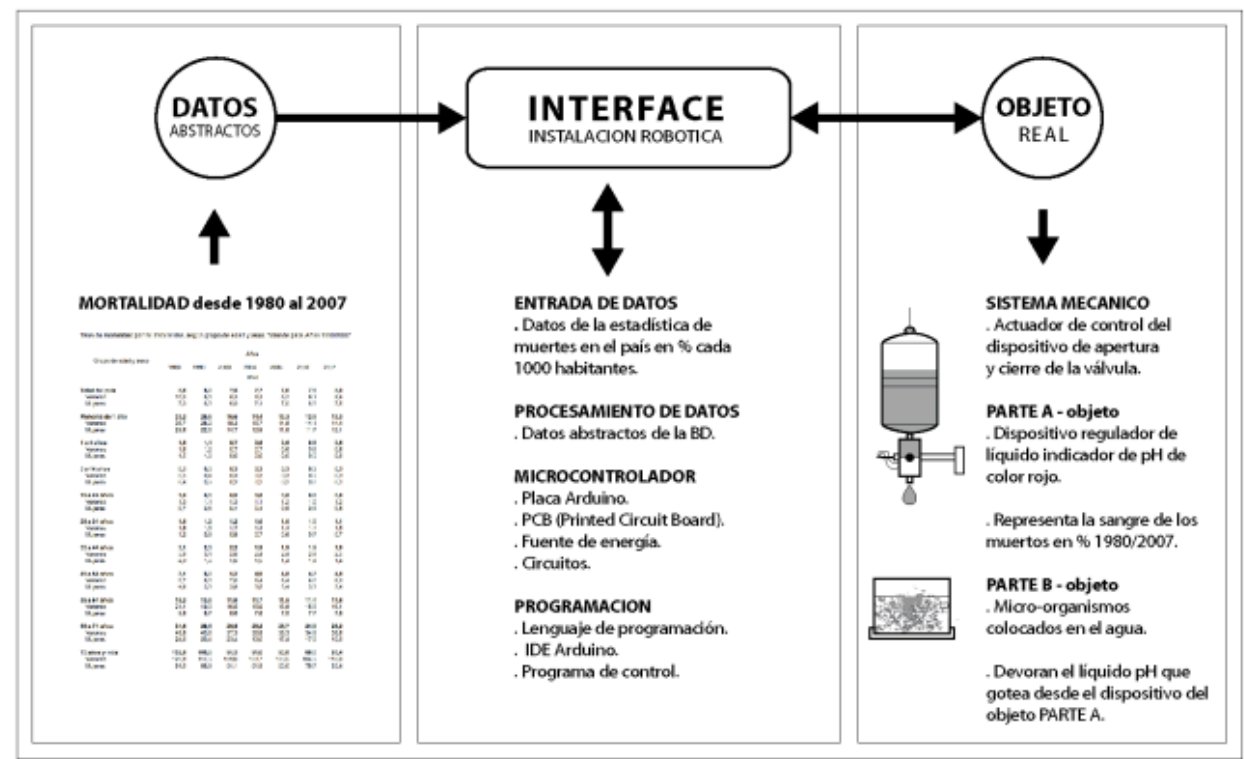

Ilustración 32. Esquema simple de funcionamiento.

La obra estaba acompañada de un texto explicativo, en el cual se ilustraba el proceso de investigación y producción de la instalación robótica. Igualmente, en dicha nota se informaba al público la disponibilidad de una manilla vibratoria, que le permitiría tener una experiencia directa con relación al flujo de datos que alimentaba la obra y propiciaba el goteo.

Generación de conciencia I permitió la visualización de datos mediante un fenómeno físico no interactivo como es el sistema de goteo diseñado para tal fin. Sin embargo, el diseño de la instalación tenía previsto un mecanismo particular de relación con el receptor consistente en un sistema de vibración, el cual se sujeta como brazalete o cánula a la muñeca para permitirle percibir las fluctuaciones de la tasa de mortalidad en forma de vibración acorde con unos parámetros pre-establecidos. Al respecto, Daniel Álvarez planteó: "La obra puede trabajar por si sola y además propone una cánula para que el público se la coloque con el fin de recibir una descarga pequeña en la muñeca al caer de cada gota" (D. Álvarez, comunicación personal, 23 de septiembre de 2014).

Si bien es cierto la instalación no tenía previsto una interacción que modificara el devenir de la obra, también era cierto que el mecanismo de vibración propuesto por la obra involucraría a los asistentes de manera directa en la experimentación corporal del procesamiento de los datos. La participación mediada por el procesamiento de información y convertida en vibración, fue una forma de relación indirecta y débil con la obra. Se 
trascendió la experiencia de visualización y se logró perturbar de manera directa a los aparticipantes a nivel sensorial a través del fenómeno de la vibración.

Con relación a la interactividad y qué tipo de obras son "Toma de conciencia I y II" Daniel Álvarez argumentó:

"Yo creo que esta cuestión de la interactividad tuvo su auge, hay modas en el arte, que a veces se mantienen, a veces caen y a veces vuelven a resurgir. Yo recuerdo que hace algunos años la palabra interactividad era furor en todos lados, en la $W e b$, en el Net art, en toda esta cuestión interactiva del espectador que modificaba la obra, que tocaba la obra, pero no creo que siempre haya sido así, me parece que ha tenido etapas las cuales han sido de aprendizaje, el mismo usuario, espectador o como lo quieran llamarlo se va adecuando, cuanto mayor conocimiento tiene se va dado un proceso del asombro al acostumbrarse. Recuerdo que en un momento nosotros hacíamos interactividad, arte interactivo y en un momento paramos y comenzamos a hacer instalaciones robóticas, y la gente se acercaba a tocar y a buscar ese tipo de respuestas de la obra, me parece que el asunto interactivo es una decisión del autor de la obra, del artista, saber si es necesario que la obra tenga algún nivel de interactividad." (D. Álvarez, comunicación personal, 23 de septiembre de 2014).

Daniel Álvarez plantea como un proceso de aprendizaje la evolución que el público desarrolla en el contacto con el arte electrónico y en particular con los procesos interactivos y dialógicos. Desde finales de los noventas la escena del arte argentino se vio impactada por la creciente participación de artistas con nuevas propuestas del arte electrónico, fenómeno que generó la construcción de un público en torno al arte electrónico.

En esta obra, la apuesta del artista y de la obra gira en torno a la contextualización y visualización de un fenómeno social. Confrontar al público a través de un mecanismo de visibilización de datos. Daniel Álvarez aclaró:

"En el caso de la obra, ella toma los datos de Internet y los traduce en un goteo a través de un suero, (...) de ahí la importancia de la obra en relación con lo que nosotros queremos expresar y nos basamos como vos decís en datos, datos que parecen muy abstractos, muy fríos pero que situados en contexto adquieren nuevos significados.” (D. Álvarez, comunicación personal, 23 de septiembre de 2014). 
¿Cómo se tipificó el rol del participante en esta obra? De acuerdo con las diversas acepciones propuestas en el capítulo cuatro del presente estudio, encontramos que, el receptor no modificó el devenir de la obra. Su participación no activó ni desactivó ningún mecanismo del dispositivo. Se tipificó entonces la noción de público. Público en tanto se configuró como una presencia latente, potencial, que se relacionó con la obra sin perturbarla, modificarla, sin incidir ni alterar ningún algoritmo o proceso del sistema, pero si dejándose permear por la obra a través de la cánula vibratoria. Trascendió la noción de espectador, el cual está estrechamente relacionado con el ver o mirar. En la presente obra el participante no se circunscribió solamente a la esfera visual, aquí se configuró como público, en el sentido de la corporalización que implicó su presencia, así como la corporalización de la vibración a través de la piel. En tanto público, recorre la instalación, la lee, la interpreta, y se sitúa frente a ella en una dimensión sensorial, tanto táctil como visual. Por tales apreciaciones se acerca a la noción de público tal como se definió para el presente estudio.

En síntesis, esta obra gozó de autonomía, no requirió de la intervención del público para su activación. El nivel de interacción que proponía era mínimo, no fue más allá de la visualización del goteo, la circulación en torno a la obra, y la experiencia sensorial de la vibración. No era posible de ninguna manera modificar los algoritmos de la instalación desde la participación.

La obra misma se propuso como interfaz, en tanto que ella misma recibía, procesaba y transformaba la información. Daniel Álvarez comentó: "En nuestro caso en particular la interfaz es la obra, la obra funciona como una interfaz, ella es la que recibe, de donde viene la información, de cómo proviene y de cómo el espectador la recibe."

Respecto al componente innovativo de la obra, Daniel Álvarez precisó: "La pluridimensionalidad que las obras convocan se convierte en un elemento innovador con referencia al contexto de Buenos Aires de aquella época." (D. Álvarez, comunicación personal, 23 de septiembre de 2014).

El artista referenció los nexos entre formalización, conceptualización y circulación en el contexto de Buenos Aires de aquella época. La relación entre ciencia, arte y tecnología encontraron en el componente social un terreno fértil para la creación y la innovación. 


\section{Conclusiones}

El presente documento intentó describir desde el contexto del arte electrónico y en particular en la escena de Buenos Aires entre los años 2002 y 2012, aspectos referidos al distanciamiento del rol del público hacia papeles y lugares nuevos, lo cual trajo variaciones notables en lo que generalizamos como público del arte. Se puntualizó en la tipificación de dichos roles a través de texto teóricos y del análisis de las obras de arte electrónico seleccionadas para el presente estudio y exhibidas en la ciudad de Buenos Aires en dicho período. A través de dimensiones de análisis de orden teórico se indagó en la construcción de términos como los de público, observador, espectador, usuario, interactor y actor, con el fin de describir como dichas nociones se manifestaron en las diferentes instalaciones interactivas y robóticas analizadas, así como en las entrevistas sostenidas con los artistas y en la relación que el público estableció con las obras.

\section{1.}

El conocimiento sobre el impacto del arte electrónico y el dispositivo tecnológico en la escena del arte en Buenos Aires en la década 2002 - 2012 va más allá de los simples usos y saberes técnicos que los artistas y los diseños de las instalaciones propusieron. Dicho saber implicó, igualmente, el entendimiento de su singularidad, de su especificidad, de su conexión con la investigación/creación, así como con las prácticas artísticas contemporáneas, así como la intervención en el espacio político, económico, social y cultural de la ciudad. Las instalaciones analizadas incorporaron tecnología que generó un cierto aire de novedad, aun cuando los sensores, kinects, ordenadores y los proyectores de vídeo eran ya dispositivos relativamente estándares en el escenario global, lo cierto es que su aparición en museos y galerías de Buenos Aires convocó la atención general.

La presente pesquisa en torno al arte electrónico en la década 2002 - 2012 en Buenos Aires permitió evidenciar como este género ganó un espacio en la escena local del arte; en particular se posicionó paulatinamente y ganó espacios en museos, galerías y universidades, así como entró a formar parte de convocatorias, certámenes y de instituciones relacionadas con la tecnología y las comunicaciones. Las organizaciones relacionadas con el arte durante esta década, tomaron conciencia del advenimiento de las nuevas expresiones que el arte electrónico proponía por aquel entonces. Se materializaron dichas intuiciones a través de 
convocatorias y certámenes que desde la institucionalidad fueron configurando un escenario para el surgimiento y apoyo a este tipo de arte y expresiones. En paralelo, dicha actividad fue forjando la aparición de un nuevo público capaz de disfrutar y participar de nuevas actuaciones según las características que el arte electrónico proponía. Las crecientes realizaciones basadas en los medios electrónicos aparecieron con más frecuencia en las exhibiciones locales. Esto generó un impacto en el espacio expositivo, así como en las maneras de circulación de dicho arte.

El fenómeno interactivo que surgió de manera singular en esta década, desarrolló nuevas perspectivas para los receptores de la obra. La gran diversidad de soportes electrónicos utilizados en las obras estudiadas, permitió la integración de medios, el sincretismo expresivo, así como el uso interrelacionado de diversas tecnologías. El tratamiento del espacio expositivo y los tiempo externos e internos de las obras se expandieron en diversas direcciones expresivas que dieron lugar a la resignificación del lugar del público en el horizonte del arte electrónico.

Se vivenció experiencialmente el diseño de las instalaciones. La participación ocupó un lugar central en la mayoría de las instalaciones estudiadas. En el mismo sentido, la construcción y materialización de formas novedosas de interacción cuestionaron el rol tradicional del espectador. Se propició una traslación de sentido de la obra hacia el receptor y desde el receptor hacia una resignificación de las nociones de público, surgiendo categorías como observador, espectador, usuario, interactor y actor. Los diversos procesos reactivos, generativos, de uso, de interacción y actuación fueron caminos abiertos que facetaron roles diversos.

Más allá de la parafernalia tecnológica y objetual, las instalaciones en cuestión se configuraron como dispositivo en la medida que referenciaron un conjunto amplio de elementos tanto materiales como de producción, que posibilitaron la realidad de las mismas, así como el encuentro con ellas a través de la participación. La instalación interactiva como constructo híbrido articuló diversidad de artefactos, lo que confirmó su carácter abierto, cambiante y resbaladizo que la hizo polisémica, a la vez que propició nuevas maneras de interrelación.

La tecnología utilizada en las instalaciones en cuestión, recurrió a diversidad de sensores, para variables como posición, movimiento, velocidad, aceleración, presión y 
temperatura, así como procesamiento de información proveniente de Internet o de bases de datos. Los puentes de relación que se establecieron con las variables citadas fueron posibles a partir de conexiones que procesaron la información por medio de algoritmos, códigos, y programas. Las informaciones procesadas provenientes de las diversas variables de entrada se transformaron o materializaron a través de interfaces explicitas o tácitas las cuales moldeaban de manera directa o indirecta la participación requerida para activar las obras.

El receptor en su tránsito por el espacio/tiempo interactivo, asumió diversos papeles, roles o niveles de participación, los cuales dependieron de las diversas propuestas de interacción diseñado por el artista o por él mismo. Se pudo entonces identificar grados de relación, intromisión, perturbación, interacción, uso y actuación a partir de las diversas maneras de activación que los diseños de las instalaciones estudiadas propusieron. Nos encontramos entonces ante un horizonte amplio de actuaciones. El que vivenció las instalaciones activó desde diferentes lugares y papeles las obras. A su vez el contacto con las obras provocó la resignificación y expansión de la noción de público tradicional.

La interacción con una instalación tiene lugar en un espacio compartido. Las variables en juego que la constituyen producen una interacción entre el dispositivo y quien lo experimenta. En esta interrelación surge una valoración estética propia de cada instalación, que da sentido y existencia a la propia obra. El análisis llevado a cabo evidenció que cada producción adquiere su sentido en el acontecer con el público, de ahí que las generalizaciones adquieren sus propias particularidades en la obra misma, como es el caso de las distintas facetas que el participante encarna al vivenciar y experimentar la obra. Se identificó que es en el proceso de recepción donde se gesta la experiencia individual e intransferible en cualquiera de las nociones exploradas y que a su vez son condición para la existencia de la obra.

\section{2.}

A continuación, una visión general de los roles a partir de los hallazgos encontrados en el presente estudio.

La noción de usuario se estableció en la relación dada entre el receptor y la obra. En tanto el público en los procesos de interacción, siguió una línea de instrucciones previamente dadas de manera explícita en una nota de programa. Instrucciones que hacían referencia a conductas que se debían seguir y las cuales moldeaban la noción de usuario. De hecho, las 
instrucciones que acompañaron cada instalación, sedujeron al participante para que asumiera un rol de usuario frente al objeto. Se estableció una relación de uso con la instalación, en tanto que la participación del usuario generó la obtención de unos resultados esperados. Los mecanismos diseñados generaron la ilusión o simulación de la función... La activación del dispositivo requirió colectivizar la intención del usuario, con el propósito de poner en funcionamiento el sistema. Las anteriores características se identificaron en las obras Calor, Humedad y Vapor. Turner en el Siglo XXI de Marina Zerbarini y Los Aparatos de Federico Joselevich y Julia Vallejo.

Se presentó un rasgo en común en algunas de obras estudiadas la presencia de una interfaz explícita cuya función fue mediar en la activación de los procesos potenciales del sistema. La relación dialógica que se estableció en torno a la interfaz, así como las maneras novedosas, creativas y singulares de cada obra facetaron la noción de interactor. Dicho papel, no fue ajeno a la voluntad expresa de los artistas, por el contrario, expandir y resignificar el rol de público fue justamente uno de los objetivos de las obras y por supuesto de los artistas. Por lo tanto, esta noción se configuró en la relación producida entre participante y obra, relación que fue activa y dialogante. El contacto se produjo a nivel físico a partir del gesto de las manos en el juego con la interfaz explícita. Las obras propusieron formas de interacción complejas y novedosas; que produjeron respuestas del sistema igualmente novedosos en cuanto al uso de diversidad de códigos favoreciendo la inmersión en la temporalidad de la obra. En Obras cómo Sensible del grupo Biopus, Libros de arena de Mariano Sardón, Efecto Mariposa de Patricio Gonzalez, y Alexitimia de Paula Gaetano, se evidenciaron las anteriores características señaladas y por ende la noción de interactor.

En otras obras la acción performática del público a través de movimientos o desplazamientos en el espacio escénico de la instalación materializó la noción de actor. Dicha relación de articulación y actuación que se estableció en el espacio instalativo configuró dicho rol. El diseño de las instalaciones era capaz de leer los movimientos corporales que el actor ejecutaba tales como: deambular, interponerse, tumbarse en el piso, gestualizar, danzar o dirigir haces de luz etc. No existió un contacto directo con la corporalidad de la obra. No hubo una superficie de contacto que intermediara entre el sistema y el actor. La anterior situación, determinó que la noción de público tradicional como el que asiste y participa del espacio instalativo se debilitara o desvaneciera. La experiencia interactiva diseñada favoreció 
el surgimiento de una actuación por parte del público en cuestión. Actuación que se manifestó a través del movimiento, el baile, la circulación o el deambular en torno a la obra. Así como por la acción perturbadora y consciente del actor al establecer un puente dialógico con la obra. Las obras presupusieron actuaciones que trascendieron la pasividad del público. De ahí, un actor en circulación, en movimiento, que giró en torno a la obra, la recorrió hacia su interior y exterior, se acercó y distanció, infirió y experimentó las variaciones que su influjo generaba en la instalación. La noción de actor se observó en las obras Tango virus instalación interactiva del grupo Biopus, Proxemia instalación robótica de Mariela Yeregui, Propagaciones instalación robótica de Leo Nuñez, Generación de conciencia 2 videoinstalación interactiva de Daniel Álvarez, Diego Diez y Guido Villar.

En la instalación Generación de conciencia 1 instalación interactiva de Daniel Álvarez, Diego Diez y Guido Villar, se observó igualmente que el receptor de la obra en virtud de su presencia no modificaba la obra en términos de su activación, alteración o perturbación, sin embargo, su rol de público se expandió sin abandonarlo plenamente. Es decir, su presencia latente y potencial por el contrario fue permeada por la obra por medio de juegos visuales. Como público se circunscribió a la esfera de lo visual, mediante la visualización de datos conexos con fenómenos físicos no interactivos. En el caso de algunas obras, el diseño del artista giró en torno a la contextualización y visualización de un fenómeno social. En tanto público, actualizó la instalación a través de los recorridos en torno a la misma, sin alterar ningún algoritmo o proceso del sistema diseñado. Desde su condición resignificada de público frente a la obra, la lee, la analiza, la interpreta desde variables visuales y de movimiento, desde una condición subjetiva y centrada en la presencia.

La noción de observador se identificó en la instalación robótica Espacio cambiario de Leo Nuñez. La relación que se estableció entre el observador y la obra, se dio a través de las visualizaciones de datos sobre las pantallas dispuestas para tal fin y a través de los comportamientos de los robots. Dicha relación se desarrolló en un plano netamente subjetivo. Dicho acercamiento subjetivo a la obra se vio afectado por las lecturas, interpretaciones o suposiciones que el observador hacía con respecto a los robots que deambulaban por el piso al ritmo de las fluctuaciones de una base de datos. Sin embargo, la relación dialógica no se estableció con la instalación, dado que, el comportamiento del observador, su movilidad en 
el espacio, no alteró de ninguna manera el programa que gobernaba los comportamientos de los robots. Dicha relación dialógica tan solo sucedía en el imaginario del observador.

En síntesis, se observó a través del análisis y la confrontación de las obras estudiadas en el contexto del arte electrónico en la escena de Buenos Aires 2002 - 2012, que el concepto de público tradicional y los juicios valorativos establecidos resulten incompetentes para dar cuenta de las transformaciones acontecidas a partir de la emergencia de dichas obras. Las complejas y múltiples relaciones que surgen del encuentro entre ambos componentes (obrapublico), hicieron difícil encontrar una única categoría que pueda dar cuenta de los diferentes roles que asume el espectador. Esta diferencia radica en las características de las obra, el lugar que ocupe y la relación dialógica que establezca con ella.

El arte electrónico abre un camino para que el público actúe, observe, interactúe o sea usuario, dependiendo del lugar de emplazamiento que el artista le asigne. Su rol escrutado desde las dimensiones de análisis trabajadas en esta investigación ofrece relevantes pautas de reflexión para el campo de la estética digital, así como para la profundización y análisis de dicho rol en el campo del arte electrónico, sin pretender agotar el tema, ni mucho menos generar criterios de verdad. El fenómeno de la interactividad y en particular la mediación de los diversos dispositivos encontrados en el análisis, así como su continuo crecimiento enriquecerá la prominencia de nuevas nociones y re-significaciones del término público. Como dice Claudia Giannetti: "Está claro que la deconstrucción de los valores tradicionales del arte y su estética comenzó en el seno del arte mismo, a partir del momento en el que incorporó a sus métodos los de las tecnologías digitales" (Giannetti C., 2002, p. 168). La expansión de la experiencia del público en el contexto dinámico y progresivo del arte la ciencia y la tecnología actual y futura, posibilita comprender la importancia del arte electrónico en el escenario de Buenos Aires, sus consecuencias sobre el entorno del arte y su papel en la construcción de nuevas realidades estéticas.

Se entiende entonces necesaria la continuidad de las investigaciones que puedan indagar y profundizar en la resignificación de las nociones de usuario, actor e interactor para evitar la utilización inoportuna del término y pueda continuar siendo un interrogante que se renueve a partir de la asunción de su propia contingencia. 


\section{Tabla comparativa de obras}

\begin{tabular}{|c|c|c|c|c|c|c|c|c|c|c|c|}
\hline Obra & Autor & Formato & $\begin{array}{c}\text { Nota de } \\
\text { programa } \\
\text { explicativa }\end{array}$ & Temática & Interfaz & $\begin{array}{c}\text { Multi - } \\
\text { medialidad }\end{array}$ & $\begin{array}{c}\text { Tipo de } \\
\text { sensores }\end{array}$ & $\begin{array}{c}\text { Grado } \\
\text { Inmersión }\end{array}$ & $\begin{array}{c}\text { Conexión } \\
\text { Internet }\end{array}$ & $\begin{array}{c}\text { Conexión } \\
\text { Bases de } \\
\text { datos } \\
\text { externas }\end{array}$ & Rol \\
\hline Sensible & $\begin{array}{l}\text { Grupo } \\
\text { Biopus }\end{array}$ & $\begin{array}{l}\text { Instalación } \\
\text { interactiva }\end{array}$ & No & $\begin{array}{c}\text { Ecosistema } \\
\text { virtual } \\
\text { Vida } \\
\text { Artificial }\end{array}$ & $\begin{array}{c}\text { Explícita } \\
\text { Membrana }\end{array}$ & $\begin{array}{c}\text { Proyecciones } \\
\text { visuales y } \\
\text { sonoras }\end{array}$ & $\begin{array}{c}\mathrm{De} \\
\text { Movimiento }\end{array}$ & Fuerte & No & No & Interactor \\
\hline $\begin{array}{l}\text { Libros de } \\
\text { arena }\end{array}$ & $\begin{array}{l}\text { Mariano } \\
\text { Sardón }\end{array}$ & $\begin{array}{l}\text { Instalación } \\
\text { interactiva }\end{array}$ & No & & $\begin{array}{l}\text { Explícita } \\
\text { Arena }\end{array}$ & $\begin{array}{c}\text { Proyecciones } \\
\text { visuales }\end{array}$ & $\begin{array}{c}\mathrm{De} \\
\text { Movimiento }\end{array}$ & Fuerte & $\mathrm{Si}$ & $\mathrm{Si}$ & Interactor \\
\hline $\begin{array}{l}\text { Efecto } \\
\text { Mariposa }\end{array}$ & $\begin{array}{l}\text { Patricio } \\
\text { Gonzalez }\end{array}$ & $\begin{array}{l}\text { Instalación } \\
\text { interactiva }\end{array}$ & No & Ecológica & $\begin{array}{l}\text { Explícita } \\
\text { Arena }\end{array}$ & $\begin{array}{c}\text { Proyecciones } \\
\text { visuales }\end{array}$ & $\begin{array}{c}\text { De } \\
\text { Movimiento }\end{array}$ & Fuerte & No & No & Interactor \\
\hline $\begin{array}{l}\text { Calor, } \\
\text { Humedad y } \\
\text { Vapor. Turner } \\
\text { en el Siglo } \\
\text { XXI }\end{array}$ & $\begin{array}{l}\text { Marina } \\
\text { Zerbarini }\end{array}$ & $\begin{array}{l}\text { Instalación } \\
\text { interactiva }\end{array}$ & $\mathrm{Si}$ & Ecológica & $\begin{array}{c}\text { Explícita } \\
\text { Manoplas }\end{array}$ & $\begin{array}{c}\text { Proyecciones } \\
\text { visuales }\end{array}$ & $\begin{array}{c}\text { De } \\
\text { Temperatura }\end{array}$ & Débil & No & No & Usuario \\
\hline Los Aparatos & $\begin{array}{l}\text { Federico } \\
\text { Joselevich, } \\
\text { Julia } \\
\text { Vallejo }\end{array}$ & $\begin{array}{l}\text { Instalación } \\
\text { Interactiva, }\end{array}$ & $\mathrm{Si}$ & Sicológica & $\begin{array}{l}\text { Explícitas } \\
\text { Variadas }\end{array}$ & $\begin{array}{c}\text { Proyecciones } \\
\text { visuales } \\
\text { Sonoras, } \\
\text { Táctiles }\end{array}$ & $\begin{array}{c}\text { De } \\
\text { Movimiento } \\
\text { Temperatura }\end{array}$ & Fuerte & $\mathrm{Si}$ & No & Usuario \\
\hline Tango Virus & $\begin{array}{l}\text { Grupo } \\
\text { Biopus }\end{array}$ & $\begin{array}{l}\text { Instalación } \\
\text { interactiva }\end{array}$ & No & $\begin{array}{c}\text { Procesos } \\
\text { virales }\end{array}$ & $\begin{array}{c}\text { Tácita } \\
\text { Cuerpo } \\
\text { movimiento }\end{array}$ & $\begin{array}{c}\text { Proyecciones } \\
\text { visuales y } \\
\text { sonoras }\end{array}$ & $\begin{array}{c}\text { De } \\
\text { Movimiento }\end{array}$ & Fuerte & No & No & Actor \\
\hline $\begin{array}{l}\text { Generación de } \\
\text { Conciencia II, }\end{array}$ & $\begin{array}{l}\text { Daniel } \\
\text { Alvarez, } \\
\text { Diego } \\
\text { Diez, } \\
\text { Guido } \\
\text { Villar. }\end{array}$ & $\begin{array}{c}\text { Video } \\
\text { instalación } \\
\text { interactiva }\end{array}$ & $\mathrm{Si}$ & $\begin{array}{c}\text { Salud } \\
\text { Pública }\end{array}$ & $\begin{array}{c}\text { Tácita } \\
\text { Cuerpo } \\
\text { movimiento }\end{array}$ & $\begin{array}{c}\text { Proyecciones } \\
\text { visuales }\end{array}$ & $\begin{array}{c}\text { De } \\
\text { Movimiento }\end{array}$ & Fuerte & $\mathrm{Si}$ & $\mathrm{Si}$ & Actor \\
\hline Proxemia & $\begin{array}{l}\text { Mariela } \\
\text { Yeregui }\end{array}$ & $\begin{array}{c}\text { Instalación } \\
\text { robótica }\end{array}$ & No & $\begin{array}{c}\text { Relacional } \\
\text { Conductual } \\
\text { Autómatas }\end{array}$ & $\begin{array}{c}\text { Tácita } \\
\text { Cuerpo } \\
\text { movimiento }\end{array}$ & $\begin{array}{c}\text { Proyecciones } \\
\text { visuales y } \\
\text { sonoras }\end{array}$ & $\begin{array}{c}\mathrm{De} \\
\text { Movimiento }\end{array}$ & Fuerte & No & No & Actor \\
\hline Propagaciones & Leo Nuñez & $\begin{array}{c}\text { Instalación } \\
\text { robótica }\end{array}$ & & $\begin{array}{l}\text { Autómatas } \\
\text { celulares }\end{array}$ & $\begin{array}{c}\text { Tácita } \\
\text { Cuerpo } \\
\text { movimiento }\end{array}$ & $\begin{array}{c}\text { Proyecciones } \\
\text { visuales y } \\
\text { sonoras }\end{array}$ & $\begin{array}{l}\mathrm{De} \\
\mathrm{Luz}\end{array}$ & Fuerte & No & No & Actor \\
\hline
\end{tabular}




\begin{tabular}{|c|c|c|c|c|c|c|c|c|c|c|c|}
\hline Obra & Autor & Formato & $\begin{array}{c}\text { Nota de } \\
\text { programa } \\
\text { explicativa }\end{array}$ & Temática & Interfaz & $\begin{array}{c}\text { Multi - } \\
\text { medialidad }\end{array}$ & $\begin{array}{c}\text { Tipo de } \\
\text { sensores }\end{array}$ & $\begin{array}{c}\text { Grado } \\
\text { Inmersión }\end{array}$ & $\begin{array}{c}\text { Conexión } \\
\text { Internet }\end{array}$ & $\begin{array}{c}\text { Conexión } \\
\text { Bases de } \\
\text { datos } \\
\text { externas }\end{array}$ & Rol \\
\hline Alexitimia & $\begin{array}{l}\text { Paula } \\
\text { Gaetano }\end{array}$ & $\begin{array}{l}\text { Instalación } \\
\text { robótica }\end{array}$ & No & Sicológica & $\begin{array}{l}\text { Explícita } \\
\text { Membrana }\end{array}$ & $\begin{array}{c}\text { Proyecciones } \\
\text { Táctiles }\end{array}$ & $\begin{array}{c}\text { De } \\
\text { Presión }\end{array}$ & Débil & No & No & $\begin{array}{c}\text { Espectador } \\
\text { interactor }\end{array}$ \\
\hline $\begin{array}{l}\text { Espacio } \\
\text { cambiario }\end{array}$ & Leo Nuñez & $\begin{array}{c}\text { Instalación } \\
\text { robótica }\end{array}$ & & Económica & No interfaz & $\begin{array}{l}\text { Proyecciones } \\
\text { visuales }\end{array}$ & $\begin{array}{c}\mathrm{De} \\
\text { Movimiento }\end{array}$ & Débil & $\mathrm{Si}$ & $\mathrm{Si}$ & Observador \\
\hline $\begin{array}{l}\text { Generación de } \\
\text { Conciencia I }\end{array}$ & $\begin{array}{l}\text { Daniel } \\
\text { Álvarez, } \\
\text { Diego Díez } \\
\text { Guido } \\
\text { Villar }\end{array}$ & $\begin{array}{c}\text { Instalación } \\
\text { robótica }\end{array}$ & $\mathrm{Si}$ & $\begin{array}{l}\text { Salud } \\
\text { Pública }\end{array}$ & No interfaz & $\begin{array}{l}\text { Proyecciones } \\
\text { visuales }\end{array}$ & $\begin{array}{c}\text { Micro- } \\
\text { controlador }\end{array}$ & Débil & $\mathrm{Si}$ & $\mathrm{Si}$ & Público \\
\hline
\end{tabular}




\section{Referencias Bibliográficas}

Alonso, R. (2005). Algunas propiedades de las instalaciones interactivas. Fundación Telefónica.

Argíles, M. S. (2009). La instalación en España, 1970-2000. Madrid: Alianza.

Bajtín, M. (1992). Estética de la creación verbal. (S. XXI, Ed.) México.

Beniger, J. (1989). The Control Revolution technological and Economic Origins of the Information Society. U.S.A: Harvard University Press.

Benjamin, W. (1989). La obra de arte en la época de su reproductibilidad técnica, en Discursos interrumpidos I. Madrid: Taurus.

Bense, M. (1973). Estética: consideraciones metafísicas sobre lo bello. Buenos Aires: Nueva Visión.

Burger, P. (1987). Teoría de la Vanguardia. Barcelona: Península.

Córdova, I. C. (1978). 80 años de pintura argentina. Buenos Aires: Librería de la ciudad.

Couchot, E. (1998). La tecnología en el arte. De la fotografía a la realidad virtual. Paris:

Chambon.

Crary, J. (2007). Las técnicas del observador: visión y modernidad en el siglo XIX. Murcia: Cendeac.

Eco, U. (1990). Obra abierta. Barcelona: Ariel.

Eco, U. (1990). Obra abierta. Barcelona: Ariel. 
Ferla, J. L. (2005). El audiovisual en Argentina: Uniformación global y creación local. Bogotá.

Franke, H. W. (13 de junio de 1970). Estética cibernética. Boletín del CCUM - Centro Cálculo de la Universidad de Madrid.

Franke, H. W. (1995). Kunst Kontra Technik. Wege zur Computerkunst.

Freeland, C. (2003). Pero ¿esto es arte? Madrid: Cátedra.

Fundación telefónica. (2006). Catálogo. Interactivos-Ambientes, redes, teleactividad. Buenos Aires.

Fundación Telefónica. (2009). Arte y nuevas tecnologías - Catálogo sexta edición. Buenos Aires.

Gaetano, C. (2005). Arte y nuevas tecnologías 2005.Catalogo Premio MAMBA/Fundación telefónica. Buenos Aires.

García, A. C. (2007). “Locus et corpus”, en Carlos Trilnick. Bogotá: Pontificia Bolivariana.

Giannetti, C. (1997). Estética de la simulación. En C. Giannetti, Arte en la era electrónica. Perspectivas de una nueva estética. Barcelona: L’Angelot.

Giannetti, C. (2002). Estética digital. Sintopía del arte, la ciencia y la tecnología. Langelot.

Gibson, W. (1984). Neuromante. Barcelona: Minotauro.

González, V. (2013). Art Nexus, 12.

Hernández, I. (2009). Interactividad, vida artificial y espacio/tiempo en las instalaciones inmersivas. Arkadin, 4 (2).

Herrero, D. E. (1988). Estética. Barcelona: Herder. 
Iser, W. (1987). El acto de leer. (Taurus, Ed.) Madrid.

Jauss, H. R. (1992). Experiencia estética y hermenéutica literaria. madrid: Taurus.

Judd, D. (1965). Specific objects. Art Yearbook.

Kac, E. (1998).

Lyotard, J.-F. (1998). La condición postmoderna - Informe sobre el saber. Buenos Aires: Catedra.

Malina, R. F. (1999). El comienzo de una nueva forma de Arte.

Manovich, L. (2005). El Lenguaje de los Nuevos Medios de Comunicación. Barcelona : Paidos.

Manovich, L. (2005). El lenguaje de los nuevos medios. Paidos.

Marchan, S. (1986). Del arte objetual al arte del concepto. Madrid: Akal.

Nusenovich, M. (2000). Arte y experiencia en Córdoba.1995-2000. Proyecto de Investigación. Córdoba: CIFFyH..

Oubiña, D. (2005). Catálogo "En Arte y Nuevas Tecnologías. Premio MAMBA, Fundación Telefónica, 2004, 2003 y 2002. (F. telefónica, Ed.) Buenos Aires.

Pérez, J. R. (1991). El arte del vídeo. Introducción a la historia del vídeo experimental. Barcelona: Ediciones del Serbal.

Piñero, B. (2006). Algunas dimensiones de análisis para el abordaje de una obra de arte electrónico. Seminario de Artes Electrónicas. (U. N. Febrero, Ed.) Buenos Aires.

Rancière, J. (2010). El espectador emancipado. Manantial. 
Santana, R. C. (05 de 07 de 2007). Influencia de la Estética en los objetos virtuales... Recuperado el 7 de diciembre de 2014, de Tesis doctorales en red.

Telefónica. (2005). Catalogo premios MAMAB-Fundación Telefónica - Arte y nuevas tecnologías - espacio-Fundación telefónica-2005. Buenos Aires.

Telefónica. (2011). Catalogo premios MAMAB-Fundación Telefónica - Arte y nuevas tecnologías -espacio-Fundación telefónica- 2007.

Valesini, S. (2014). La instalación como dispositivo escénico y el nuevo rol del espectador. Buenos Aires: Tesis de Maestría.

VVAA. (2006). Support for the Arts Handbook. Melbourne: Gobierno Australia.

Waelder, P. (2008). Arte interactivo: nuevas estrategias en la relación dialógica entre el espectador y la obra de arte. Barcelona.

Watkins, J. (1997). Catálogo, Installation is everything and everything is Installation. You are here. Re-siting installations.

Wiener, N. (1958). Cibernética y Sociedad. (E. Sudamericana, Ed.) Buenos Aires.

Wikin, Y. (1984). El telégrafo y la Orquesta - La Nueva Comunicación. Barcelona: Paidós. 


\section{Referencias de Internet.}

Adler, J. (2015). Recuperado el 30 de Mayo de 2015, de http://www.gearcomunicacion.com.ar/jornadas_2015/eje4/4a.\%20Adler_corregido.pdf Arte y tecnología en la argentina: confluencias disciplinares y metodológicas en la escena contemporánea Jazmín Adler

Alonso, R. (2005). Comisariado y media art. Recuperado el 23 de abril de 2014, de http://www.roalonso.net/es/arte_y_tec/comisariado.php

Alonso, R. (3 de abril de 2005). Arte y tecnología en Argentina - los primeros años. Recuperado el 1 de junio de 2014, de Roalonso: http://www.roalonso.net/es/arte_y_tec/primeros_anios.php Álvarez, D. (2010). Proyecto agua y aceite. Recuperado el 12 de febrero de 2015, de https://proyectoaguayaceite.wordpress.com/tag/laboratorio-de-produccion/page/8/

1Álvarez, D. (2012). Proyecto Agua y Aceite. Recuperado el 13 de febrero de 2015, de https://alvarezolmedo.wordpress.com/category/10_laboratorio-produccion-cceba/page/5/

Biopus, G. (2006). Recuperado el 16 de Febrero de 2015, de http://www.biopus.com.ar/instalaciones.html\#tango

Biopus, G. (2007). Proyecto Biopus. Recuperado el 15 de febrero de 2015, de http://www.biopus.com.ar/obras/sensible/index.html

Biopus, G. (2007). Recuperado el 15 de febrero de 2015, de http://www.biopus.com.ar/txt/textos/Vinculacion_entre_imagen_y_sonidoEmiliano_Causa-Matias_Romero_Costas.pdf

Biopus, G. (2007). Recuperado el 17 de Febrero de 2015, de http://www.biopus.com.ar/txt/textos/Emiliano_Causa_Los_virus_y_el_arte.pdf 
Biopus, G. (2009). Recuperado el 20 de Febrero de 2015, de http://www.biopus.com.ar/txt/textos/Sensible_interactividad_vida_artificial_y_musica_en_t iempo_real.pdf

CCEBA. (2009). Expo proyectos MediaLaab. Recuperado el 12 de Junio de 2014, de http://www.cceba.org.ar/v2/index.php?option=com_content\&view=article\&id=192:expomedialab09\&catid $=48$ :laboratorio\&Itemid $=67$

CCEBA. (2010). Expo proyectos MediaLaab. Recuperado el 12 de Junio de 2014, de Convocatoria:

http://cceba.org.ar/v2/index.php?option=com_content\&view=article\&id=233:convocatoria 2010\&catid $=48$ :laboratorio\&Itemid $=67$

CCEBA. (2012). Laboratorio de producción proyectos. Recuperado el 12 de Junio de 2014, de http://www.cceba.org.ar/v3/blog_medialab.php?ida=1\&id=46

Centro Cultural Recoleta. (2012). Jorge Glusberg. Recuperado el 22 de febrero de 2015, de Centro virtual de arte argentino: http://cvaa.com.ar/03biografias/glusberg_jorge.php

FASE. (2009). Que es fase. Recuperado el 13 de mayo de 2014, de Encuentrofase: http://encuentrofase.com.ar/qué-es-fase

FASE. (2010). Sobre FASE 2. Recuperado el 13 de Mayo de 2014, de Fase encuentro de arte y tecnología: http://encuentrofase.com.ar/sites/default/files/programas/fase2.pdf

FASE. (2011). Sobre FASE 3. Recuperado el 13 de mayo de 2014, de Fase encuentro de arte y tecnología: http://encuentrofase.com.ar/sites/default/files/programas/fase3.pdf

FASE. (2012). Sobre FASE 4. Recuperado el 13 de Mayo de 2014, de Fase encuentro de arte y tecnología: http://encuentrofase.com.ar/sites/default/files/programas/fase4.pdf

Fundación telefónica. (2012). Conócenos. Recuperado el 6 de diciembre de 2014, de Portada: http://www.fundacion.telefonica.com.ar/conocenos-portada.html 
Giannetti, C. (1999). MECAD Journal. Recuperado el 14 de septiembre de 2015, de http://www.mecad.org

Gómez, M. (2013). ¿Qué es el New Media Art? Una Aproximación terminológica.

Recuperado el 29 de Abril de 2015, de Interactive: http://interartive.org/2012/04/newmedia-art-termino/

González, P. (2012). Recuperado el 1 de Noviembre de 2014, de http://patriciogonzalezvivo.com/2011/efectomariposa/

Joselevich, F. (2010). Recuperado el 12 de enero de 2015, de http://www.cceba.org.ar/v3/blog_medialab.php?id=12

Joselevich, F. (2010). Recuperado el 23 de enero de 2015, de Los Aparatos: http://www.losaparatos.ludic.cc/?page_id=111

Kac, E. (Mayo de 1997). Arte Robótica: Un manifiesto. Recuperado el 12 de Febrero de 2015, de http://www.ekac.org/kac.roca.sp.html

Molas, V. (2005). Entrevista. Recuperado el 30 de abril de 2014, de http://archivo.lavoz.com.ar/herramientas/imprimir_nota.asp?nota_id=52886

Nuñez, L. (2007). Leo Nuñez. Recuperado el 12 de noviembre de 2014, de http://www.leonunez.com.ar/espacio_cambiario.html

Nuñez, L. (2010). Leo Nuñez. Recuperado el 11 de noviembre de 2014, de http://www.leonunez.com.ar/espacio_cambiario.html

Pasman, J. (2006). Arte y nuevas tecnologías ¿nuevos educadores? Obtenido de http://sic.conaculta.gob.mx/documentos/982.pdf Arte y nuevas tecnologías inuevos educadores? 
Rueda, M. d. (1999). La Nostalgia de las Vanguardias en Argentina La Aventura Concreta MADI-Cinética. Recuperado el 22 de mayo de 2014, de Historia IUNA:

http://historiaiuna.com.ar/wp-content/material/2012_de_rueda_arte_concreto.pdf

Sardón, M. (19 de octubre de 2005). Educar. Recuperado el 15 de noviembre de 2014, de Portal educativo : http://portal.educ.ar/noticias/entrevistas/mariano-sardon-artes-electroni1.php

Sardón, M. (2008). Libros de arena. Recuperado el 23 de Febrero de 2015, de http://www.marianosardon.com.ar/books_of_sand/libros28_esp.htm

Telefónica. (2011). Premio MAMBA- Fundación Telefónica. Arte y Nuevas Tecnologías. Recuperado el 20 de Junio de 2014, de http://www.telefonica.com.ar/fundacion/quehacemos-noticias-septima-edicion-premio-MAMBA.html

Weibel, P. (2000). EL mundo como interfaz. Recuperado el mayo de 2015, de Elementos: http://www.elementos.buap.mx/num40/pdf/23.pdf

Yeregui, M. (2005). Recuperado el 19 de enero de 2015, de http://www.liminar.com.ar/pdf05/yeregui.pdf

Yeregui, M. (2005). Visión del arte - Bola de nieve. Recuperado el 21 de noviembre de 2014, de http://www.boladenieve.org.ar/artista/6170/yeregui-mariela

Youtube. (2009). Propagaciones - Leo Nuñez. Recuperado el 23 de enero de 2015, de https://www.youtube.com/watch?v=5BTa1c3Y6Fo

Zerbarini, M. (2006). Recuperado el 24 de Noviembre de 2014, de http://www.boladenieve.org.ar/artista/821/zerbarini-marina 


\section{Índice de Ilustraciones}

Ilustración 1 - Gesto interactivo. Sensible, instalación interactiva. Grupo Biopus. .81

Ilustración 2 Generación de criaturas con vida artificial. Sensible, instalación interactiva. Grupo Biopus.

Ilustración 3 Esquema básico del sistema. Sensible, instalación interactiva. Grupo Biopus.

Ilustración 4 Sombras generadas por el contacto con la pantalla elástica. Sensible, instalación interactiva. Grupo Biopus.

Ilustración 5 Participación del público en el espacio escénico de la instalación interactiva

Tango Virus.Grupo Biopus.

Ilustración 6 Nacimiento de un virus. Instalación interactiva Tango Virus.Grupo Biopus..92

Ilustración 7 Imágenes de los virus (izquierda) y generadas por los virus (derecha) ............92

Ilustración 8 Vista de los sistemas de procesamiento. Instalación interactiva Tango

Virus.Grupo Biopus

Ilustración 9. Detalle instalación interactiva Libros de arena.Mariano Sardón.....................99

Ilustración 10. Efecto mariposa - Instalación interactiva - Patricio Gonzalez.

Ilustración 11 Esquema general de la instalación 1. Efecto mariposa - Instalación interactiva - Patricio Gonzalez

Ilustración 12- Esquema general de la instalación 2. Efecto mariposa - Instalación interactiva - Patricio Gonzalez

Ilustración 13 - Representación de capas - sustratos. Efecto mariposa - Instalación interactiva - Patricio Gonzalez

Ilustración 14- Especificación de cada capa. Instalación interactiva - Patricio Gonzalez.113

Ilustración 15. Calor, Humedad y Vapor. Turner en el Siglo XXI. Instalación interactiva. Marina Zerbarini.

Ilustración 16. Extractor de pensamientos enquistados.Instalación interactiva. Federico Joselevich.

Ilustración 17. Acelerador de tramitaciones síquicas. Instalación interactiva. Federico Joselevich.

Ilustración 18.. Generación de Conciencia II - de la serie @Agua_Y_Aceite Video instalación interactiva.

Ilustración 19. Esquema simple del funcionamiento: Base de Datos + Internet + Objeto + Video.

Ilustración 20.. Proxemia. Instalación robótica interactiva, Mariela Yeregui.

Ilustración 21. Detalle de la instalación. Propagaciones. leo Nuñez.

Ilustración 22. Detalle célula. Propagaciones. Leo Nuñez. …………………………..........143

Ilustración 23. Circuito. Propagaciones. Leo Nuñez. …………………………………......143

Ilustración 24. Pedestales. Propagaciones. Leo Nuñez........................................................144

Ilustración 25. Espacio cambiario Instalación Interactiva. Leo Nuñez. ...............................148

Ilustración 26. Detalle lumínico de Autómata celular.........................................................149

Ilustración 27. Alexetimia - Instalación Robótica 2005...................................................153

Ilustración 28. Alexetimia - Instalación Robótica 2006..................................................155

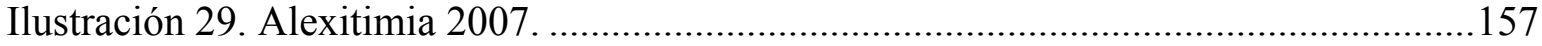

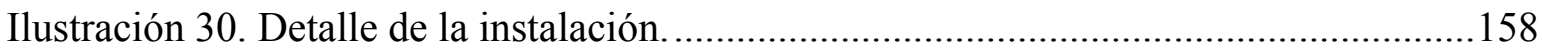

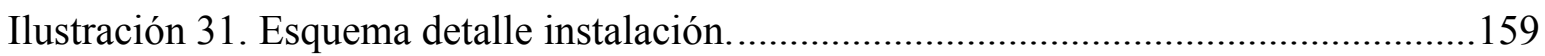


Ilustración 32. Esquema simple de funcionamiento.

\section{Anexo 1. Entrevistas}

\section{Entrevista Emiliano Causa.}

¿Para comenzar hablemos del concepto de autoría, y desde allí como ves la participación del público?

Siempre ha estado dando vueltas la discusión acerca de si el público es coautor de la obra, esa fue como la primera cuestión que se planteó. Yo sentía que, si bien la interactividad habilitaba al espectador de alguna forma en el proceso creativo y en el desarrollo de la obra, decir que el público es coautor de la obra para mí no era del todo cierto y hasta impreciso en algún punto. A partir de un momento la figura que construí fue la de entender que yo era autor no de un discurso sino de la gramática, una gramática que permite que el público digamos construya un discurso. Yo lo que entonces creo, es que las obras interactivas o al menos las que yo trato de crear, apuntan a construir una meta-máquina discursiva, una máquina que de alguna forma ponga el discurso de los otros en funcionamiento. Entonces considero que el rol del artista interactivo está en esto de construir la gramática con el sistema de reglas que esa máquina funciona.

¿Crees que el público-espectador en algún momento en su interacción con la obra abandona su papel?

Yo creo que ahí se están mezclando dos palabras, no abandona su rol de público, pero

si el de espectador. No todo trabajo multimedial es interactivo, de hecho, en las muestras que nosotros hemos participado éramos más una excepción que la regla, hay mucho trabajo multimedia que todavía ubica al público en el papel de espectador. Creo que en algún momento el arte interactivo se va a terminar separando del arte multimedial. Creo que lo que pasa en el arte interactivo es que el artista cede un cierto lugar en el proceso creativo, se lo cede al público, pero esto lo obliga a él a ponerse en otro lugar que no es en la construcción del discurso sino en la construcción de esta máquina discursiva.

¿Cuál es el concepto central de la obra Tango Virus? 
El concepto central de la obra está en relación con captar el gesto corporal de las personas y transformarlos en una entidad viva que trasciende al gesto inicial que lo creó y poner esto en funcionamiento en un proceso relacionado con lo musical destructivo. Las ideas son la participación en la creación desde la destrucción, la creación de la cosa vida desde lo viral y lo gestual.

En la obra Tango Virus el público es productor de desequilibrio y en la obra Sensible productor de equilibrio. En el fondo de nuestras obras hay una idea que tiene que ver con una utopía nuestra, la cual todavía no alcanzamos, que es el pensar que la obra pueda dialogar con vos, para que una obra pueda dialogar con vos te tiene que percibir en tus particularidades subjetivas, en parte nuestra búsqueda es lograr obras que tomen algo de tu particularidad subjetiva y la integren al discurso de la obra. En la mayoría de las obras partimos de tomar algún gesto del público el cual es un primer indicio de la particularidad subjetiva. En Tango Virus ese gesto tiene que ver con la danza del tango, en Sensible tiene que ver con tocar la pantalla.

¿Cuáles son las estrategias de interacción que se diseñaron en las obras en cuestión? Invocamos interfaces que de alguna forma puedan captar algo de la gestualidad, el gesto del público, también partiendo del hecho que en esta posmodernidad digamos lo gestual se cifra en la individualidad, también está vinculado al narcisismo imperante, he ahí un señuelo, porque si yo dejo que vos te muestres un poquito en la obra, vos te vas a disponer y a conectar con la obra.

¿Cuál es la interfaz en Tango Virus?

No podría decir que es el cuerpo, porque yo entiendo que la interfaz es lo que conecta el cuerpo con el fenómeno que es la obra, en este caso sería ese sistema de visión artificial que capta el movimiento, la mirada, el sensor a través de la cámara que es el medio que conecta las dos cosas, mi cuerpo como interactor con los algoritmos de la obra. Hay un teórico que plantea que la interfaz es un espacio donde se articula el cuerpo, la herramienta y la acción22, entonces al tratar de ubicar la interfaz en algún elemento en particular de alguna forma le estamos errando, porque en realidad la interfaz es ese espacio de articulación;

\footnotetext{
${ }^{22}$ Gui Bonciepe de proyecto de interfase, expuestas en su libro "Del objeto a la interfase" Ediciones Infinito, 1999
} 
en el caso de Tango Virus sería el cuerpo en interacción con el sistema de mirada artificial, los algoritmos y el proceso de activación del virus.

¿Cuál es la interfaz en Sensible?

La pantalla táctil y elástica está funcionando como espacio de articulación e interfaz. La única manera de activar la obra y su diseño algorítmico y visual es a través del contacto directo con la pantalla táctil.

¿Cuál o cómo es el proceso metodológico del diseño o elección de la interfaz?

Es una buena pregunta, digamos que hay un proceso de búsqueda, el cual surge de ideas mías muy trabajadas posteriormente en equipo. Ideas muy mediocres que después crecen mucho en el proceso, las ideas iniciales son bastantes tontas. Los disparadores que a mí se me ocurren son de tono casi teatral, yo pienso las relaciones entre la obra y el público, cosas como "me gustaría hacer una obra en que la gente pueda lastimar a la obra y la obra pueda sanar" "me gustaría hacer una obra en que la obra pueda atacar al público", pienso relaciones entre la obra y el público sin que aun haya surgido una temática específica, a partir de esas relaciones empiezo a pensar que tipo de interfaz puede ayudarme a lograr eso que estoy pensando, pero siempre pensando en la interfaz como un binomio entre el dispositivo y el cuerpo.

La relación entre público y obra a través de procesos relacionales mediados por una interfaz nos conduce a la interactividad. ¿Se podría hablar de interactividad en el caso de las obras robóticas en las cuales los procesos relacionales se dan entre máquina y máquina o entre robot y robot?

Yo comprendo el concepto, no quiero decir que lo que el arte robótico propone a ese nivel no sea interactivo, habría que discutirlo, no es a lo que yo llamo interactivo. Para mí en lo interactivo hay un humano en la relación, del otro lado hay otra cosa, puede ser otro humano o una cosa. Pero las relaciones de interacción entre elementos artificiales no las llamo interactividad, sino como interacciones de un sistema complejo de elementos que están interactuando entre sí.

¿Que desarrollos multimediales se encuentran presentes en las dos obras en cuestión Tango Virus y Sensible?

Yo creo que de las obras que nosotros hemos hecho desde mi apreciación personal, la obra Sensible es una de las que mejor funciona, y esto es debido a que se produce una 
integridad de los medios que en las otras obras nos ha costado o no hemos logrado encontrar, me refiero a eso que yo le llamo el gesto interactivo, es ese lugar en donde el interactor no puede diferenciar entre sus acciones y lo que sucede, eso en Sensible pasa de esa manera. Una persona acciona sobre una pantalla y esto genera unos fenómenos físicos que el público no logra diferenciar; en ese sentido si ha habido una evolución entre Tango Virus y Sensible. Yo creo que Tango Virus es una de nuestras primeras investigaciones, acerca de como representar el proceso viral, en cambio Sensible es una obra más refinada acerca del proceso complejo que imita la vida, con más emergencia de orden en sentido estricto, es mucho más complejo y difícil controlar lo que sucede en Tango Virus.

¿Podemos entonces afirmar que la obra es una obra inmersiva?

Es una obra muy inmersiva técnicamente hablando. Me he preguntado desde que la hicimos cuales son los factores que la hacen una obra inmersiva, yo he visto al público interactuar con la obra 15 o 20 minutos de toda la franja etaria habida y por haber, niños de 10 años hasta gente de ochenta años. Hay algo muy impregnante en la imagen, esa especie de cuadro abstracto constante que se va creando, creo que está bastante lograda la relación entre lo que sucede a nivel visual y a nivel sonoro, (uno de los aspectos más difíciles de trabajar en la obra) a cada elemento visual lo acompaña un elemento sonoro, de lo contrario sería un caos y nos sería muy musical. Sensible llega a tener hasta cuatrocientas criaturas virtuales en escena representadas visualmente lo que implicó el análisis respecto el espacio sonoro lo que nos llevó a hacer traducciones análogas entre lo visual y los procesos sonoros o musicales. Entonces los elementos del lado visual con relación a los elementos sonoros en uno y otro espacio son distintos, la analogía está a nivel de procesos, por ejemplo: aumenta la densidad de la imagen y aumenta la densidad musical, pero la forma en que aumentamos la densidad sonora no responde a una acumulación como ocurre con los elementos visuales, responden desde otros parámetros. En Tango Virus el fenómeno musical es destructivo, se parte de una pieza sonora pre-establecida mientras que ocurre algo constructivo sonoramente hablando, considero que el logro sonoro en la obra es muy alto, en relación con Tango Virus se denota entonces una evolución significativa. Los procesos visuales y sonoros vinculados con los procesos de acción del público producen esa integridad que yo le llamo el gesto interactivo y en últimas genera el fenómeno inmersivo de la obra.

¿La relación entre público y obra es lineal, uno a uno o es simultánea? 
Inicialmente se da uno a uno, pero se vuelve plural rápidamente. Cada espectador crea un tipo de criatura las cuales se relacionan entre si y genera un ambiente en el cual la participación se torna plural y simultánea.

Con relación a el comportamiento del tiempo en las obras tratadas ¿Se gesta las respuestas entre público y obra en tiempo real o hay algún tipo de diferido en términos temporales?

En todas es en tiempo real, la relación con los sensores se da en tiempo real, lo que pasa es que es otro tiempo, que es el tiempo de esos seres virtuales, entonces hay un tiempo que es el del gesto interactivo y el tiempo de las criaturas. Por ejemplo, yo hago un baile en Tango Virus el cual se transforma en virus y este a su vez continua por su cuenta, lo mismo pasa en Sensible donde se crean unas criaturas a partir de la interacción y estas luego tienen su propia vida y tiempo.

¿Qué tan diferenciador es el espacio entre ambas obras?

Por ejemplo, no es lo mismo cuando lo hicimos versión mesa, a cuando la hicimos versión pared (3mts x 2mts). La versión en Barcelona y Madrid estuvo en relación con un evento de Nokia. Cuando el público interactúa en la mesa, las relaciones entre las personas son casi obligadas, en la escala mayor de la pared, todos se enfrentan a la pared, pero la relación es más individual, esto debido a la nueva espacialidad y escala de exhibición de la obra. La mesa invita a apoyarte con los codos a quedarte más tiempo, la pared por el contrario retiene al público menos tiempo. El dominio del campo visual que el público tiene sobre la mesa es completo mientras que sobra la pared es parcial.

¿Qué tanto de innovación presentaron las obras en su contexto en la escena de Buenos Aires al momento de ser exhibidas?

Creo que las dos en su momento fueron muy innovadoras, en el caso de Tango Virus no recuerdo en ese momento instalaciones interactivas de ese nivel de trabajo que funcionaran con sistemas de captación de movimiento, y que a la vez propusieran procesos de vida artificial, existían algunos referentes a nivel mundial, aunque muy escasos. En el caso de Sensible igualmente no se ha hecho mucho acá.

¿Qué tanto de ciencia hay en las obras en cuestión?

En el caso de Sensible, todo el desarrollo del sistema de vida artificial es un diseño nuestro desde cero, algo no común dado el nivel de algoritmos que se encuentran en red 
donde el caso ya está resuelto. El programa está diseñado byte por byte por nosotros, usando Proccesing. Los procesos de programación han sido el resultado de la investigación a partir de las preguntas que en su momento nos hicimos con ambas obras acerca de la captación del movimiento, la interactividad, el gesto interactivo, y los procesos de programación, así como del software respectivo. 


\section{Entrevista Paula Gaetano Adi.}

¿Qué tipo de obra es Alexitimia?

Para mí es un agente autónomo robótico. Es un robot, yo lo veo y lo entiendo como un robot. En el mundo del arte puede ser una escultura robótica o una instalación robótica, yo en realidad lo veo como un objeto robótico.

¿Cómo fue el proceso de investigación previa del proyecto?

Alexitimia comienza a ser conceptualizada en el 2005 y la empiezo a desarrollar realmente en el 2006. Son prácticamente dos años de desarrollo. Antes de Alexitimia yo acababa de terminar la universidad en Córdoba Argentina, y básicamente lo que venía haciendo era un poco de performance y metiéndome con las nuevas tecnologías más por el lado del video. Por esos días lo que más me interesaba era un discurso más relacionado con el feminismo y ver como la tecnología operaba en el cuerpo humano, cercano a los discursos referidos a las prótesis y los ciborgs. Por allá en el 2005 empiezo a pensar en construir un cuerpo completamente artificial y esta pequeña pregunta cambió realmente el foco o el eje sin que en ese momento estuviera pensando en un robot, pero la pregunta ¿Cómo crear un cuerpo artificial? me llevó a investigar sobre robótica, el concepto de inteligencia artificial y luego sobre el arte robótico aproximándome a la escultura una variable que yo desconocía en ese momento.

¿Cómo ves al público, observador o interactor con relación a tu obra? ¿Crees que el completa la obra, o simplemente la contempla?

Yo pienso siempre en el espectador. El público completa la obra, no creo en el artista aislado, esta es una obra interactiva por lo tanto contempla otro que se va a relacionar con la obra. Para mí el espectador está en la construcción básica de la obra, es una condición sine qua non. Como piensa el espectador o como se relaciona con la obra es otra cosa.

¿La obra va acompañada de alguna nota de programa la cual le da algún tipo de información al público?

No necesariamente, yo nunca explico, hay un catálogo donde se da algún tipo de explicación, hay un murmullo en el ambiente que dice que la obra hay que tocarla, pero yo no soy lo suficientemente explicita, es desde ahí como me interesa el espectador. Pienso en el espectador y el robot en este tipo de obra interactiva como un encuentro. Pienso en un 
encuentro entre dos cuerpos, dos especies distintas las cuales se encuentran y tratan de dialogar como pueden. Te encontrás con esa cosa que no tiene forma, que está a una altura bajita y hacés lo que podés. ¿Que podés hacer con una cosa que no te dice nada? Naturalmente es el tacto lo único que te permite interactuar, antes la gente trata de hacer gestos y la obra no reacciona, hasta que no queda otra opción que tocarla. Cuando la tocan y el robot empieza a transpirar ocurre la magia, se da el click del encuentro, comienza el dialogo. A mí no me gusta dar pautas y si pasó alguien y no la tocó está bien, no es para él esta obra. La obra requiere un espectador que observa y tiene paciencia.

¿Con relación al arte interactivo cómo concibes al público, observador, usuario o interactor con relación a Alexitimia?

En obras interactivas, para mí el interactor es un ser humano, que tiene un bagaje político, cultural, que proviene de un determinado lugar, es un ser único. Trato de entenderlo no como una globalidad. Para mi es importante entender que son subjetividades, que no hay un público ideal, no lo pienso así en mi obra, creo que hay unos determinados parámetros que ayudan a tipificar cual es el espectador de cada obra. Hay obras en las cuales hay un público que pasa e interactúa con la obra y hace algo. Hay otras que no, están destinadas a un tiempo, una altura, a un tipo de fisicalidad, a un género, a una raza. Es importante empezar a pensar en el espectador no en términos generales, no somos todos iguales. Para mí no hay interactores, para mí es muy general ese término, entonces yo lo pienso en realidad como humanos, como personas, después de eso hay tipificaciones, es decir son humanos no son animales, son niños o son adultos, es decir trato de pensarlos como individualidades no como generalidades.

¿Qué hace interactiva Alexitimia?

Inicialmente me interesaba establecer una relación entre una máquina y un humano. Para poder establecer esa interrelación fue necesario hacerla interactiva, me interesaba el dialogo; no todas mis obras son interactivas. En Alexitimia para mí el tacto era importante. Era como el espectador a través del tacto y de la afectividad podía relacionarse con una obra de arte. Entonces naturalmente la obra fue interactiva a través de dicho diálogo. Sin embargo, no veo la interacción como una parte fundamental de mi obra en general.

¿Qué tipo de sensores y tecnología usas en esta obra? 
Utilizo sensores piezoeléctricos flexibles de unos $10 \mathrm{cms}$. de longitud, hechos de un material que cuando se deforma genera una señal. En realidad, la obra no reacciona al tacto sino a la flexibilidad del material. La obra está hecha de látex el cual al ser presionado genera técnicamente el fenómeno que posibilita la obra.

¿Qué tipo de código hace que la presión produzca la emisión de agua?

Hay un código muy básico consistente en un procesador, hay un pick el cual está programado para que envíe una señal hacia las bombas de agua las cuales se activan.

¿Qué reacciones observaste en el público frente a los fluidos o líquido que la obra expele, dada cierta aversión que tenemos frente a esto?

Inicialmente fue muy inocente la propuesta. Pensé que a todo el mundo le iba a gustar, pero por supuesto que claramente no. Es muy interesante eso, ver el proceso de conceptualización, el desarrollo posterior y el momento grande en los años 2007/08 y ver la obra frente a la gente y aprender a partir de ahí. Hay gente que le encanta y se quedan horas con la obra como si fuera una mascota y otras personas que a la primera vez que la tocan les parece un asco, se espantan, la consideran anti-higiénica, en fin, hay un rango variado de reacciones y es precisamente eso lo que empieza a darle sentido a la obra. Era algo más que tocar, era además todo lo que venía después del acto de tocar gracias a los fluidos los cuales siempre despiertan cierta cosa visceral. No hay un solo espectador que haya entrado en contacto con la transpiración del robot (que en realidad es agua) que no haya tenido algún tipo de reacción, que no haya dicho algo. Es una experiencia corporal, hay alguno que lo huelen casi automáticamente, pero no tiene olor.

¿En términos de la interfaz, cual es la relación entre la membrana y el concepto de enfermedad que maneja la obra?

En realidad, yo estaba buscando un título, porque la obra ya estaba en mi mente. Mi mejor amiga es sicóloga sicoanalista. Le comenté sobra la obra en mente y ella me dijo: ese robot es alexitímico. A partir de ahí, yo comencé a investigar en el asunto del cual no sabía nada. Todos los seres que no pueden expresar sus sentimientos y emociones verbalmente lo van a expresar a través del cuerpo y de ahí vienen un montón de enfermedades que son sicosomáticas como por ejemplo transpirar o ponerse rojo o incluso llegar a empezar a desarrollar algo más grave. Entonces me pareció que es así, el robot es alexitímico, no tiene movimiento, no tiene voz, se expresa a través del cuerpo que es lo único que tiene. 
¿Qué tan inmersiva consideras esta obra en términos del público?

No creo que sea muy inmersiva. Es un objeto, uno no entra al mundo de Alexitimia. Uno se relaciona con la obra como si se relacionara con un objeto.

¿Cómo es la relación espacio temporal con la obra por parte del espectador?

La respuesta es inmediata siempre y cuando haya una presión sobre la membrana. Hay personas que son muy sutiles, si no presionas no sucede nada. La obra siempre ha sido expuesta en espacios interiores, nunca en espacios exteriores. La obra ha viajado por distintas culturas y ha funcionado dependiendo de la intensidad cultural de los espectadores. En algunos lugares la reacción es mínima dada la frialdad de la gente, en otros es más cálida o agresiva la relación dependiendo de la gente de su cultura.

¿La obra muestra o están a la vista sus componentes interiores?

No en ningún momento, todo su mecanismo está oculto para la gente. Esto genera en gran medida su organicidad, la sensación de que es un ser orgánico, se supone que hay un dispositivo, pero justo ese ocultamiento hace más mágico su momento.

¿Cuánto de ciencia tiene Alexitimia?

Yo creo que todas las obras que utilizan tecnología y tienen un desarrollo prolongado tienen metodología, proceso y conceptualización. No imaginé Alexitimia de la nada, hubo una intención primera de hacer una investigación, de averiguar cosas como: ¿cuáles son las principales olas de la inteligencia artificial? ¿qué está pasando en la robótica? Aunque el proceso es intuitivo y no hay una metodología científica rigurosa, sin embargo, hay proceso de investigación, eso es seguro.

¿Cuánto de innovación trajo Alexitimia en la escena del arte electrónico de Buenos Aires cuando hizo su debut?

Pasó algo curioso que fue la participación y premiación de la obra en el certamen VIDA de Telefónica, algo totalmente inesperado, por cuanto para mí en ese momento era un asunto muy inocente. Al pasar lo de VIDA me quedó evidente que la obra era innovativa, que planteaba algún tipo de innovación con relación a la obra de arte interactivo desde otro lugar, un lugar más corporal, más íntimo. A pesar de lo anterior yo no pienso las obras como innovación, creo que ellas se relacionan con otras obras y tienen unas obras que le anteceden. No las veo como nuevas, quizás tendrán aspectos que no fueron explorados, pero era una cuestión de tiempo, que si no era yo alguien lo iba a hacer. 


\section{Entrevista Federico Joselevich.}

\section{Háblame acerca de tú obra Los Aparatos.}

Bueno con los aparatos, nos pasó una cosa muy particular, yo vengo trabajando con temas de interactividad, con la noción de usuario, más que de usuario, alguien que está del otro lado. Desde mis comienzos con la programación allá por los años 1980-1990, trabajaba siempre con la idea de que al otro lado había alguien. Cuando la cosa empezó a cuajarse en el arte digital por allá a finales de los años 90, siempre pensé que la gente hace uso de lo que uno pone allí y no solo hace uso, sino que comienza a ser parte de ello, no solo como partícipe necesario sino como pieza más de ese rompecabezas; las discusiones académicas teóricas después comienzan a hablar de arte interactivo, y en particular de interacción como la acción entre dos.

Lo que hicimos con la obra los aparatos en compañía de Julia Vallejos compañera del proyecto fue trabajar tres aspectos: el momento en que la gente quiere leer algo, saber de qué van cada una de las piezas, ese momento de pausa de lectura, de entender más allá de lo que está viendo. Después hay que trabajar un punto de vista, de lo estético, de lo que uno contempla cuando se acerca a la obra, como se ve el conjunto, como está dispuesta en el lugar, y en tercer lugar como la gente se comunica con la obra, cual es la forma de interrelacionarse con ella. Lo que empezó a pasar con esa obra en particular por el planteo que ella tiene es que trascendió hacia lugares que nosotros no imaginábamos, por ejemplo cuando estaba en el montaje de la obra con sus diferentes componentes, estaba en el proceso de soldar cables etc., se acerca una señora con un papel impreso, que lo había sacado de La trituradora de culpas, me mira con cara de preocupación y me dice: dime que significa esto, - la gráfica, es una gráfica random que la genera el sistema de cualquier manera, la señora estaba realmente muy preocupada - , le dije que quizás podría consultar un profesional o triturar las culpas allí, como las de todos los demás, cosa que efectivamente hizo.

A medida que fueron pasando los días encontramos que se generaron muchas y diversas formas en las cuales la gente había trabajado, por ejemplo hay una máquina - El acelerador de tramitaciones síquicas - que tiene un formulario en donde la gente puede escribir cual es la tramitación que quiere, yo me fui encontrando con papelitos doblados escondidos detrás de otras obras, que decían cosas como angustia, resolver mis problemas 
profesionales y laborales por mi indefinición sexual, estaba sellado y doblado por la máquina y luego tirado. Lo que nos pasó es que la gente tenía la sensación de que las maquinas funcionaban; tanto así que una amiga de Julia nos llamó para contarnos que hacía meses que estaba con muchos conflictos con su pareja y no sabía que hacer, y que cuando usó la maquina se dio cuenta que tenía que dejarlo, que la máquina le ayudó a tomar la decisión.

Entonces lo que nosotros conseguimos con los aparatos fue trascender el objeto, poder hacer que la gente realmente sintiera lo que nosotros estábamos tratando de transmitir, para mí eso es una cosa fundamental en las obras. Me importa que sean bonitas, que funcionen bien, pero sobretodo que la gente pueda tener una sensación, que puedan jugar, que puedan quizás divertirse un rato o sentir otras cosas, poder depositar algo allí.

¿Qué podríamos decir de la relación emisor receptor en términos de la obra propuesta?

Hay un punto en donde me hace ruido el tema de pensar que la gente no pueda leer lo que uno está queriendo decir, yo creo que voy a analizar el rol del interactuador cuando uno dice que no puede leer, yo creo que la gente puede leer mucho más de lo que uno cree; ahí está la historia, cuando uno le propone diversas formas de abordaje. Hace poco fui a ver la exposición de Le Parc en el MALBA, hay una cosa muy interesante que plantea Le Parc que se ve muy claramente en esa exposición cuando habla de que el arte cinético no tiene un solo punto de vista, y que ese es el quiebre que plantea el arte cinético. Para mí, esto es una de las cosas fundamentales, cuando uno piensa que la gente va a leer las cosas desde un solo lugar, ahí hay un equívoco porque hay múltiples interpretaciones y diversas formas de acercarse, además en estos tiempos en que lo digital te permite abordarlo desde otros lugares.

¿Qué nivel de inmersión por parte del público logra la obra desde tu punto de vista?

Yo creo que hay algo muy importante, la instalación en general, ese grupo de pequeñas piezas produce una enseñanza, porque las piezas más sencillas de todas, las más pequeñas implicaban simplemente apretar un botón y que se prendiese una luz, lo que generaba una reacción, por ejemplo el dispositivo decisor portátil no es más que un botón que uno aprieta y al azar se prende una luz y nos dice si si o si no, si es ahora o no es nunca, o es que hay que esperar o hay que interpretar; ese solo hecho de que la gente depositaba el valor de la decisión en ese aparato, les provocaba cosas de esperanza, de desazón, de esperar cosas, no me dio la respuesta que yo esperaba o me la dio, y ahora qué hago con esto. El tema 
del deseo estaba claramente representado allí. Yo creo que el deseo, los sueños y la poesía no son un tema recurrente en el arte digital; yo creo que en el arte digital lo que hay es algo más de ciencia ficción o de denuncia acerca de la realidad o de la ecología, o de la economía, no se trabaja en el arte digital en el imaginario de lo que a uno le pasa.

¿Consideras que el público completa la obra o sigue siendo ajeno a la misma?

Nosotros perseguíamos a través de esta obra recrear los laboratorios de los años 1900, entonces desde esa óptica los interactuadores son usuarios, completan la obra en el sentido de la performance que se genera, pero los aparatos no se completan con ellos, los aparatos son; hay un punto en que necesitan a la gente para poder ser, esto sucede cuando los ves a cada uno por separado. Cuando uno ve la instalación en si ella necesita de la gente, se requiere que la gente participe, interactúe activamente. En Brasil cuando se exhibió la obra, sucedió con relación al Extractor de las emociones, el cual es una video-instalación, en el cual se puede ver un atardecer y a la vez se pueden ver mensajes de tipo conductista como mañana va a ser un gran día, mañana te vas a sentir mejor, todo está bien, de cierta manera era un reírnos de ciertas cuestiones de la sicología, el caso es que durante la exhibición una señora empleada de la embajada Argentina desaparece del escenario por espacio de media hora, cuando regresa, vuelve con los ojos en lágrimas muy angustiada, efectivamente le habíamos extraído una angustia muy profunda, ella nos decía: eso que ustedes mostraron es el Tigre ( no era el Tigre, era el Paraná arriba, lo cual no importa, para ella era el tigre) ella continuaba diciendo esa gente que ustedes han puesto ahí yo la conozco. Para mí, ese momento en que la señora manifiesta su emoción, es el momento en que la obra se completa.

¿Cuáles son las estrategias de interacción que propone la obra, son efectivas?

Las estrategias son efectivas en gran medida, hay algunos aparatos en que la estrategia no lo es, yo creo que el Desintelectuador en el sentido de la efectividad es el menos efectivo. Consiste en una voz que hay del otro lado, una voz pregrabada que habla y habla, tratando de desintelectualizarte pero que en realidad está produciendo una intelectualización, es una ironía porque nunca te escucha, para mi ese aparato a nivel de interacción es el que menos funciona, es cierto que la gente se acerca y escucha, pero inmediatamente cuelga. En el sentido opuesto el aparato que más logra la interacción o inmersión del espectador es la Trituradora de sentimientos de culpa, igualmente La aceleradora de Tramitaciones síquicas. En el caso de La Trituradora de sentimientos de culpa, se observa que la gente 
inmediatamente tiene sentimientos de culpa para sacarse de encima, no importa como sea el aparato, ya desde el nombre empieza a atraer; después el aparato tiene una serie de pasos a seguir que son muchos, para que finalmente pueda salir el papel y poder triturar la culpa, o sea el espectador se tiene que poner un casco, se tiene que arrodillar, pensar en una culpa, esperar a que salga el papel impreso por una cinta transportadora, sale humo, se prenden luces, finalmente cuando sale el papel impreso tiene que decidir qué hacer si se lo queda o lo tritura, todo el anterior proceso hace que el espectador se quede 3 o cinco minutos interactuando y pensando en eso, para luego en algunos casos se alargue y puede que el espectador se lleve el papel hasta su casa y siga pensando en ello por mucho más tiempo. La propuesta de permitir poner el cuerpo en la obra con otras participaciones yo creo que es la más efectiva.

¿Qué tan multimedial es la obra, que tanto se involucran los sentidos del público en la obra?

De entrada, descartamos el olfato y el gusto, la obra no propone una experiencia olfativa ni gustativa. El tacto está porque se produce la sensación de tocar la madera, tocar estas cosas viejas, la vista está porque los objetos hacen la instalación netamente visual, el oído en la medida que la maquinas tienen o emiten ruidos. Nosotros trabajos la posibilidad de experimentar con distintos puntos de vista, de proponerle al espectador distintos sentidos, en ese sentido lo multimedial surge del contacto con los materiales de la instalación, lo viejo, la madera, las texturas y del otro lado la pantalla de proyección de recuerdos.

¿Cómo es la experiencia espacial que propone la obra, como es el recorrido del espectador con la obra?

Yo creo que la obra genera una experiencia espacial, yo creo que funciona como si fuera una feria de la ciencia, los aparatos comparten una misma estética, todas tienen un atractivo que hace que el espectador recorra la instalación para indagar en otro aspecto de su ser, creo el espectador no se queda con la idea de que vio muchos aparatos, sino por el contrario vivo una experiencia totalizante referida a su ser. Por cierto, para nosotros ha sido muy difícil colocar la instalación en un espacio en el que hay otras obras instaladas puesto que considero la lectura de la obra se ve modificada. En el caso de los aparatos nos hicimos la pregunta respecto al recorrido, si entras a ver la instalación con que aparato te encontrás 
primero, este o aquel. Primero que vas a hacer con tú estado de ánimo y después como te vas a proteger de los tiempos difíciles. De todas formas, el planteo del recorrido es sugerido.

¿La instalación tiene una nota de programa para los espectadores?

Para cada uno de los aparatos de la instalación hemos hecho un prospecto médico una cosa muy de farmacia en el cual está toda la explicación e instrucciones respecto al aparato y la propuesta. Todas las notas tienen un tono como si fuesen un prospecto, médico o como si fuese la presentación de la empresa que te está vendiendo el aparato.

¿Qué tanto hay de ciencia en esta obra?

La obra se ubica en un plano sicológico, pensamos en el vocabulario sicoanalítico y en el significado profundo de la cosa, de otro la utilización recurrente de la palabra dispositivo como concepto desde lo sicoanalítico. En algunos casos la utilización de compuestos químicos para alterar el $\mathrm{Ph}$ y lograr el cambio de color de una cosa, a veces funcionó otras veces no. En general los dispositivos funcionan mecánicamente y en gran medida simulados.

¿Qué tanto de innovación tiene la obra?

La obra sobretodo innova en la manera de tratar a la gente, en la manera como se inscribe con los demás, no es un tobogán lúdico, no es una pantalla o espejo transformante. Es un lugar abierto donde puedes hacer lo que quieras, tú tienes problemas como los tengo yo, entonces te puedes sentar y dialogar de tus problemas con la obra, me parece que esto es lo más trascendente a nivel de la propuesta como novedad.

Durante la entrevista has utilizado varias palabras para referirte a la gente: espectador, observador, usuario e interactuador, ¿La obra permite eso, implica diferentes roles?

Sin duda, hay partes de la obra que son netamente visuales en las que se comporta la gente solamente como espectador por ejemplo con los textos o pequeñas porciones de la obra que son como esculturas; en otras es interactuador porque si no interactúa el aparato no funciona. En cuanto a comportarse como usuario, en realidad la propuesta es que la gente sea usuaria, que sea un usuario, que sea tratada como se la trataba en los laboratorios de 1900 como usuarios, se les propone irónicamente entrar como usuarios, pero en realidad no lo son. 


\section{Entrevista Leo Núñez.}

¿Qué tipo de obra son?

Yo las veo como en el caso de Propagaciones como una escultura, las veo muy escultóricas, van un poco más allá de lo cinético, por el solo hecho de que empiezan a tener comportamientos propios. Las obras cinéticas las veo como objetos móviles, sin que tengan comportamientos propios más allá de cómo es generado el movimiento, como es el caso de las motorizadas en las que uno espera que siempre haga el mismo movimiento. Por ejemplo, obras que están a la intemperie, el movimiento depende del viento y del azar. Por el contrario, las obras que yo propongo entran en el ámbito de lo robótico, que es un campo que en la actualidad se está como definiendo, de hecho, en mi tesis de maestría voy a hablar de ese tema. En el caso de mis obras el acento no está en el movimiento sino en el comportamiento del objeto, es ir un poco más allá. De hecho, hay obras robóticas que no se mueven, en síntesis, mis obras tienen como eje central el comportamiento.

¿Las obras están soportadas en un eje o pedestal, se desplazan o simplemente giran por la información que reciben de contigüidad?

De hecho, siempre que fui avanzando en mi arte, siempre fui agregándole un grado de libertad superadora entre obra y obra. Las primeras obras que he hecho son solamente relays, que son objetos binarios, pegados en una pared, inmóviles, que no se desplazan, no se mueven, solamente se accionaban. Propagaciones es un objeto que es cinético de alguna manera, tiene ese comportamiento que me llama la atención y motiva a hacerlo, es un objeto que gira mecánicamente. Posteriormente los robots de Espacio cambiario son objetos que ya se desplazan en el espacio, es como si tuvieran un grado de libertad más.

¿Cómo funcionan los sensores en la obra Espacio cambiario y cuál sería el soporte? Él es capaz de detectar el límite, tienen varios sensores que cumplen funciones diferentes. Hay varios componentes en esto. Al estar vinculado al comportamiento del mercado en tiempo real hay varias partes del sistema lo mecánico y todo lo que es comunicación entre los objetos y el nodo central que es el que está conectado a Internet, y otro sistema que es el que puede buscar en Internet y constatar el estado de los mercados y establecer esos valores diferenciales para saber cuáles están en aumento o a la baja. El soporte es múltiple material e inmaterial. La obra dada la baja incidencia del peso argentino en el 
mercado de valores, a veces funciona online, otras veces se comporta con respecto al dólar en su valor diario. Así que a veces esta online y otras offline.

¿Cómo es el proceso de transformar los datos de entrada de los valores del mercado en movimiento?

En ningún momento yo establezco lo que tiene que hacer el objeto. El objeto tiene una programación interna, cada objeto tiene el mismo programa, pero se terminan comportando de forma diferente con relación a lo siguiente: en principio está basado en comportamientos animales que tiene que ver con la agresividad, que es un comportamiento innato de los animales, que incluso el hombre lo tiene, y se relaciona con la ganancia o pérdida de territorio. Cuando establezco el proyecto de la obra, visualizo esa comparación entre estos comportamientos de agresividad y los cambios del mercado. A través de esa vinculación yo le aviso como se está comportando el mercado vs los comportamientos de agresividad programables. Es decir, el objeto recibe información de cómo se está comportando el mercado y el objeto desarrolla actitudes propias a partir de algoritmos de vida artificial como por ejemplo si volverse sumiso o ponerse más agresivo si intenta escapar o pasar desapercibido.

¿Las respuestas de los objetos o robots son en tiempo real?

Si, cuando la exhibí en Buenos Aires, el comportamiento se vinculaba a los valores del peso en el mercado en tiempo offline a partir de bases de datos. Cuando la lleve a Washington en la sede del banco mundial se relacionaba con relación al euro, el dólar y el yuan ahí si en tiempo real de acuerdo a los cambios del mercado en tiempo real online todo el tiempo.

¿Hablemos del público, la obra tiene por público un espectador pasivo o un espectador activo, que crees?

En esta obra en particular, Espacio cambiario, es solo una visualización de datos, a través de comportamientos. En este caso el público puede visualizar el comportamiento del mercado por ejemplo del dólar a través de la visualización de las luces u objetos verdes, más que ver el dato preciso es la posibilidad de ver la disputa del espacio por parte de los robots.

¿Cuál es la reacción del público frente a esa disputa por el espacio?

El público intenta interactuar con el objeto, se acerca a los robots, se introduce en su espacio, le asigna características que el objeto no tiene, por ejemplo, si el objeto se dirige 
hacia una persona o gira, el público dice ¡ah! Me vio o me detecto. El público empieza a imaginar y darle un valor interactivo al objeto, pero en realidad el objeto no lo tiene. Para mi resulta divertido observar al público, el cual espera una obra interactiva, se comporta frente a los robots como si lo fuera, pero la verdad es que no la obra no está planteada como instalación interactiva sino como instalación robótica.

¿En la obra Propagaciones el público podría interactuar con los objetos a través de la luz de su celular y alterar su comportamiento de giro?

$\mathrm{Si}$, de hecho, esta obra estaba programada para detectar niveles de luz con mi celular del momento, es un poco eso. Las teorías sobre autómatas celulares en las cuales me baso para hacer la obra parten del concepto de redes neuronales muy básicas, las cuales en los años 60 eran pensadas como sistemas cerrados. Hoy en día la ciencia es mucho más abierta y logra mucho más. En realidad, los objetos se comunican entre ellos con luz, y se establecen suposiciones con relación a su vecindad, dependiendo como estén los vecinos, cada uno se mueve o se detiene. En algún momento el sistema se vuelve estable y quedan todos detenidos en una misma posición, en este caso se apagan hasta que alguien del público planta una nueva semilla con la luz de celular y el sistema se activa de nuevo. Eso es lo que estoy haciendo, darle al sistema y al espectador la nueva posibilidad de perturbarlo, de modificarlo de alterarlo.

¿Cómo se concibe el espacio?

La disposición de los objetos está definida grupalmente. Los objetos reaccionan en cascada y luego se puede observar la relación de los grupos hacia fuera. En la obra Propagaciones, no hay una discusión de espacios entre los objetos. En Espacio cambiario lo que hacemos es transportar la información inmaterial de los valores del mercado a una discusión del espacio real por parte de los objetos, allí se puede observar una reconfiguración del espacio, y como una idea de resignificación del espacio expositivo en cuanto estoy viviendo espacialmente lo que a nivel de datos del mercado no puedo materializar. En Propagaciones de entrada existen unos requerimientos espaciales iniciales, pero el espacio sigue siendo el mismo durante la exhibición.

¿Que diferencias observas en el rol del público entre las dos obras?

Es diferente, en Propagaciones el rol del espectador es activo y necesario para la evolución del sistema. En Espacio cambiario esa situación no se presenta, el espectador no 
influye en la obra con su comportamiento in situ, la relación solo se da a nivel de visualización.

¿El concepto de interactividad se debilita en la obra Espacio cambiario?

Hay una discusión que viene desde principios del dos mil y tiene que ver con el arte con relación a muchas obras que dicen ser interactivas, han pasado muchos años al respecto; para mí una obra interactiva o dialógica, me gusta más el concepto dialógico que interactivo, es cuando esa interactividad cuenta algo, cuando suma o cierra el concepto que el artista propone. El que tenga un botón, una cámara etc. Son cosas técnicas que hoy son mucho más fáciles de realizar que 10 años atrás, yo recuerdo que hace 10 años, poner una cámara era todo un despelote, mis obras iban a 4 frames por segundo, y hoy estoy en 60 frames como si nada. Sin embargo, las obras continúan siendo conceptualmente similares, pero el desarrollo tecnológico hace que la logística y la operación de montaje sean mucho más fáciles. Hay obras en las cuales el dialogo entre espectador tiene un sentido, y se relaciona con conceptos y situaciones reales bien sea sociales o políticas, en esa dirección veo la interactividad, cuando el espectador participa y da sentido y completitud a la obra como es el caso de una obra reciente mía Desilusiones. Distinto es, pienso esas obras que se dicen interactivas solo por el simple hecho del mecanismo técnico del botón o del switche. El arte tecnológico ha evolucionado mucho y se empiezan a ver estas relaciones entre la forma de interactuar, las interfaces a usar y que todo eso cuente también parte del concepto que trabaja el artista, y a la vez cierre la obra.

¿Qué relación se establece entre el desarrollo tecnológico y las temáticas de las obras?

Muchas de las obras de principios del 2000 quizás hablaban de temas ajenos a nosotros como vida artificial, $\mathrm{ADN}$, cosas muy grandes que las personas del común están muy lejos de eso, nuestra sociedad ni se fija en eso porque tiene otras problemáticas, como la falta de servicios públicos como agua, luz, alcantarillado. Así es como la Argentina empieza poco a poco a tocar temáticas más propias que ajenas.

¿Qué nivel de influencia han tenido las empresas que han favorecido el arte electrónico en Argentina como telefónica, CCEBA y otras?

En la actualidad estos lugares han sido menos influyentes, el apoyo ha disminuido notablemente y esos lugares o escenarios para el arte electrónico han ido desapareciendo poco a poco, por ejemplo el CCEBA recortó su presupuesto, el MediaLab desapareció, 
Telefónica se orienta hacia otras cuestiones más institucionales, la Biblioteca especializada se disolvió, mi conclusión es que han evolucionado mucho más el arte y los artistas que las personas que desde las instituciones dirigen la escena del arte electrónico en las instituciones igualmente sucede con los museos y las galerías. Las instituciones te llaman quizás comprenden la importancia del arte electrónico y lo que está sucediendo a nivel mundial, pero a la hora de brindar el apoyo económico y logístico hay dificultades.

¿Qué tanto de innovación hay en las obras que estamos tratando según el contexto en que se mostraron?

Considero que de hecho Propagaciones ninguna. La idea era trabajar con tecnología ya existentes en torno a los autómatas celulares y utilizar algoritmos que ya se compartían en red, quizás para los espectadores y el medio sea algo novedoso sin embargo técnicamente hablando estas tecnologías ya existían y se utilizaban en el mundo. 


\section{Entrevista Daniel Olmedo}

¿Cuál es la percepción del público que tienes desde tu condición de productor de la obra electrónica?

Yo creo que esta cuestión de la interactividad tuvo su auge, hay modas en el arte que a veces se mantienen, a veces caen y a veces vuelven a resurgir. Yo recuerdo que hace algunos años la palabra interactividad era furor en todos lados, en la Red, en el net-art, en toda esta cuestión interactiva del espectador que modificaba la obra, que tocaba la obra, pero no creo que siempre haya sido así, me parece que ha tenido etapas las cuales han sido de aprendizaje, el mismo usuario, espectador o como lo quieran llamarlo se va adecuando, cuanto mayor conocimiento tiene se va dado un proceso del asombro al acostumbrarse. Recuerdo que en un momento nosotros hacíamos interactividad, arte interactivo y en un momento paramos y comenzamos a hacer instalaciones robóticas, y la gente se acercaba a tocar y a buscar ese tipo de respuestas de la obra, me parece que el asunto interactivo es una decisión del autor de la obra, del artista, saber si es necesario que la obra tenga algún nivel de interactividad.

¿En el caso de la obra objeto de la entrevista, que función cumple la base de datos a partir de la cual se pone en marcha el algoritmo que genera la obra?

Yo te tengo que contar primero una historia que nunca la cuento, en mi infancia recuerdo a mi madre la operan de cáncer, yo tenía diez años, justo el día de mi cumpleaños y le dan un año de vida, con mi padre que era enfermero la mantuvimos viva cinco años, mi padre trabajaba en el hospital ferroviario y trabaja manejando las ambulancias, y él frenaba frente de casa y bajaba los aparatos que nosotros necesitábamos porque no nos lo daban dada nuestra condición precaria, y de esa manera obteníamos, los respiradores, el aire y todas esas cuestiones. Esta obra Generación de conciencia trata sobre estas cuestiones, la gente que fallece por mala atención hospitalaria. Entonces esa base de datos está muy relacionada con una cuestión personal, tiene que ver con lo que uno quiere expresar. En el caso de la obra, ella toma los datos de Internet y los traduce en un goteo a través de un suero, esa imagen del suero, es la imagen que a mí me quedó desde pequeño. Entonces la selección de esa base de datos está relacionada con cuestiones personales y de otro artista compañero que es Guido Villar que también ha tenido una cuestión muy particular también con su padre fallecido, de 
ahí la importancia de la obra con relación con lo que nosotros queremos expresar y nos basamos como vos decís en datos, datos que parecen muy abstractos, muy fríos pero que situados en contexto adquieren nuevos significados.

¿Los Inputs o datos que recibe la obra, en la medida que la modifican podríamos decir que son interactivos en tanto que la generan?

No, no lo estoy viendo de esa manera como algo frío, me parece que es un dato cambiante, es un dato que se puede cambiar y esos pequeños cambios que le hagas te cambian el funcionamiento de la obra. En este caso digamos que la obra está dividida en censos, de tal fecha o de tales décadas, busca la información y de acuerdo a como se encuentre es como funciona la obra. Esos datos se pueden modificar online en tiempo real, y eso puede modificar la obra, en ese sentido lo que se plantea en la pregunta creo tiene mucho de correcto.

¿Cuál es para ti la interfaz de la instalación robótica de la obra que hablamos?

En nuestro caso en particular la interfaz es la obra, la obra funciona como una interfaz, ella es la que recibe de donde viene la información, de cómo proviene y de cómo el espectador la recibe.

¿La obra en el momento de ser exhibida va acompañada de una nota de programa?

Si. Nosotros nos consideramos artistas investigadores, no es la típica exposición en sí de la obra terminada, nos interesa también lo previo, lo que sucede antes de la obra. Todo ese proceso está en display, como lo armamos, el proceso de conceptualización de la obra, es algo muy fuerte como para dejarlo de lado, más allá de la ficha técnica donde se explica de lo que se trata la obra. ¿Para mí la obra es el disparador, querés saber más? Ahí está la Web, ahí está el LCD que te explica como funciona y que significa cada cosa.

¿Qué relación hay entre las obras Toma de conciencia I y Toma de conciencia II?

La relación entre las obras es: Toma de conciencia I es física, el objeto está presente recibe la información y la procesa a través del goteo y el motorcito que va tirando. Toma de conciencia II trabaja diferente, es digital, entra la información, se procesa digitalmente a través de la computadora y después se visualiza.

¿Cuál es el papel del público frente a la obra Toma de conciencia II?

A diferencia de Toma de conciencia I, que es física, y que puede trabajar por sí sola, más allá de que tenga una cánula que el espectador se coloca y le va tirando como si fuese una descarga pequeña en la muñeca que cae de cada gota, Toma de conciencia II sin el 
espectador no funciona, porque tiene unos anillos, que están estipulados alrededor, que están en el piso, el espacio expositivo es importante, se requiere un techo alto porque los anillos tienen que estar circulares, y es el espectador que en la medida que va entrando en el centro lo activa y va tirando los datos justo en el centro donde están los microorganismos. El espectador se vuelve partícipe de la obra.

¿En Toma de conciencia II cuál sería la interfaz?

Me parece que es un conjunto de cosas, no hay una sola, porque sin el espectador la obra está estática, la obra está ahí, el espectador y su interactividad con la obra generan una interfaz.

¿La obra Toma de conciencia II en el momento de ser exhibida va acompañada de una nota de programa?

$\mathrm{Si}$, nosotros explicamos muchas cosas, pero hay cosas que no, y pasa en la mayoría de las obras que hacemos, hay cosas que se plantean y son muy visibles, hay otras que si nos preguntan si las contestamos. No todo lo dejamos explícito.

¿Consideras que el público tiene un nivel de autoría en la medida que su participación activa la obra?

Pienso que hay una cuestión de ego. El artista como autor puede generar la obra y también puede ser espectador y hacer funcionar la obra, el espectador no crea la obra.

¿Qué atrae al público a la obra, que le hace participar, que riesgo asume?

Yo nunca tomé la interactividad como un juego, porque la obra en sí no habla de la interactividad como un juego, va más allá, a la gente le cuesta, ver el goteo del suero remite al espectador a algo que no quisiera ver, por eso es generación de conciencia, entonces hay una barrera que hay que superar antes de empezar a interactuar, preferimos nosotros que la visualidad de la obra sea fuerte.

¿Qué tanto hay de ciencia en ambas obras?

En nuestros trabajos hacemos mucho hincapié en lo que es la investigación, en esa época habíamos estado trabajando en el laboratorio de bio-arte de la universidad Masmónides, y ahí es donde hacemos todos los procesos de investigación de los microorganismos, visualizaciones y una de las cosas particulares que nosotros tenemos es que no trabajamos solos, siempre trabajamos con bioquímicos. Cuando nosotros generamos los alimentos para estos microorganismos, lo hacemos dentro de un laboratorio con la 
participación de Javier Camú que es un biólogo y su señora doctores en biología. Para nosotros es muy importante esa cuestión de campo, o sea, antes saber qué es lo que estamos haciendo.

¿Qué tantos cambios se suceden en el proyecto entre su formulación y el día de la puesta en exhibición del mismo?

La obra se plantea con varios estadios, varios módulos. La primera etapa es con lo que nosotros llamamos el estudio y la investigación del objeto que nosotros queremos tratar en términos de conocimiento. Con base en la investigación previa, una vez lo tenemos, entonces formulamos el proyecto, o sea que han transcurrido más de tres meses para llegar al punto de formular el proyecto. Una vez que lo tenemos formulado generamos lo que es el paper con la documentación pertinente, presupuesto, etapas de trabajo, del equipamiento que necesitamos, que tipo de personas y perfiles vamos a trabajar, químicos, biólogos, ingenieros, después nosotros entramos en el desarrollo, y por último viene la exposición y los procesos de difusión. Intentamos siempre trabajar con un tronco, con una idea troncal que después la podemos variar un poco entre las ramas, pero siempre mantenemos la idea principal.

¿Qué antecedentes tiene la obra?

Nuestras obras empiezan a partir del 2000 con la obra Agua y aceite, yo empecé a trabajar hace 20 años, desde 1990, a través de muchos eventos e instituciones, los procesos de exhibición devienen a partir de lo último, como es lo de robótica. Esa obra tiene antecedentes como Una de cal y otra de arena, que también es una instalación robótica que trabaja sobre cuestiones sociales con relación a la vivienda, también con bases de datos, con visualizaciones, con la interactividad del espectador, y todo lo que tiene que ver con los procesos de construcción que se suceden en la Villa 31. Otro antecedente es la obra que se presentó en Fundación Telefónica una instalación interactiva que procesa información online y después la twitea, relacionándola con las cosas positivas y negativas que pasan.

¿Qué tipo o procesos de evaluación implementan para constatar la efectividad de las obras?

Nosotros, subimos a la Web a través de blogs y de las redes sociales toda la información pertinente referida a las obras, fotos, planos, textos etc., igualmente han sido muy difundidas a través de la TV, al finalizar el año encontramos que el número de visitas al 
Blog crece y supera las 15.000 visitas, de esta manera podemos constatar la recepción que las obras han tenido.

¿Qué tanto de innovación proponían las obras con respecto al contexto y la época en que fueron exhibidas?

Nosotros somos muy detallistas, esas obras tienen objeto, ensambles, programación, interactividad, visualización, se trabaja con proyector, con robótica, microrganismos vivos, se interactúa, se modifican en tiempo real, a través de un microscopio se visualizan en pantalla, me parece que es un combo de mucha cuestiones técnicas, pero también es un combo de muchas cuestiones conceptuales, y eso es lo que nosotros siempre hacemos, eso es lo que nos gusta, que si hay una perfección en lo técnico la halla igualmente en lo conceptual. La pluridimensionalidad que las obras convocan se convierte en un elemento innovador con referencia al contexto de Buenos Aires de aquella época.

¿En el contexto de aquella época que temáticas transitaban las obras electrónicas en general en el escenario de Buenos Aires?

Yo creo que en ese entonces estaba Mariela Yeregui con su obra Proxemia, el grupo Biopus con su obra instalativa igualmente. Lo robótico era escaso y a la vez innovador. Nos hacíamos un planteo socio político, sentíamos la necesidad de expresarnos desde ahí la vivienda, la salud, el trabajo, la educación y encontramos esta manera, otros iban por otro lado. Que haya sido innovador finalmente el tiempo lo dirá. 


\section{Entrevista a Mariano Sardón}

Para comenzar hablemos del concepto de autor y la relación que juega el público con relación a este concepto. ¿Qué piensa al respecto?

Quizás yo debería decir ciertas cosas con respecto del autor, pero lo cierto es, que en ese entonces, se hablaba mucho de la dilución del autor en el sentido clásico, me acuerdo de esas cosas y creo que en algún punto eran ciertas dado que el rol del espectador cumplía una función fundamental en la hechura misma material de la obra, entonces en ese momento el darle al espectador posibilidades de que pudiera manipular la obra, dejarlo resolver cosas que probablemente uno no tenía apriori tan resueltas y sobre las cuales no tenía tanta potestad sobre la forma y uno sentía que ciertamente se había corrido de cierta noción de autor. En el fondo, la cuestión de la autoría si uno la pensaba en términos formales, como quien decide ¿dónde va el rojo en el plano?, ya está bien, el rojo se lo podemos delegar al espectador, pero el plano, la tela y los pinceles los voy a definir yo. En la obra hay un cubo, hay arena y una serie de cosas que pasan con la Red, el Internet y un montón de software que las decidí yo, en todo caso, sí se podía pensar en ciertos grados de libertad que se daba al espectador y después había cosas que efectivamente los espectadores hacían mucho más allá de lo que uno podía compensar ya en el devenir mismo del uso del trabajo.

¿Podríamos decir que el espectador cuando interactúa con la obra la completa?

La desarrolla, le da temporalidad, le da formalidad y tiene un rol participativo, yo creo que es más radical el cambio para el espectador que para el autor. El autor en realidad no deja de ser autor de una serie de cosas, si no es muy simple, ve y decíle a un artista que no firme una obra interactiva y listo ahí está la respuesta de cuál es el lugar del autor. (...) Pero en ese punto creo que para el espectador si es distinto, porque es quien vive la experiencia en definitiva, y si había para mí un lugar importante en ese trabajo, era el lugar de la interacción misma como un objeto artístico no tanto el objeto en sí.

En un momento dado dices que el código se flexibiliza y hay cierto nivel de aleatoriedad que tú no podrías determinar ni saber a dónde iba a parar ¿Que podés decir al respecto?

Claro, esa obra en particular tiene dos aspectos de cosas impredecibles, una es que el programa te busca páginas de Jorge Luis Borges en Internet, lo cual son una serie de 
decisiones que son randóm computacional, igualmente había una base de datos, dado que en esa época Internet no era muy copada. Ese trabajo en realidad lo empecé a hacer en UCLA en Los Ángeles en el 2001 todo lo que tuvo que ver con parsecs y búsqueda de información. En ese entonces, en esa universidad había una Red que era como de un mega que para la época era rápida. Buscar en Internet era una cosa que se podía hacer con cierta liviandad, esa búsqueda era independiente de Libros de arena, después cuando armo Libros de arena y uso ese desarrollo, primero lo conectamos a la Red cuando lo montamos en el Museo de Arte Moderno, pero bueno se caía se colgaba a cada rato la Red, los tiempos eran otros, por lo tanto, decido guardar todo en una base de datos.

Pensando un poco en el concepto de Endoestética ¿Se podría hablar de un espectador interno y un espectador externo, es decir un espectador que tiene unas vivencias propias y un alguien que se sumerge en la obra y tiene otras?

Sí, claramente porque en realidad en ese trabajo se podría ver dos estéticas paralelas y una decisión de desarrollar un aspecto orientado hacia una estética determinada minimalista, geométrica, y formal, donde todo el proceso interno de esto quedó supeditado a esta propuesta, entonces la idea era darle justamente un elemento de falta de conocimiento para quizás impulsar más el disparo metafórico de este trabajo. Ahora cuando te enterabas de lo otro no es que perdía cierta metáfora, pero te llevaba a un espacio completamente distinto.

¿La obra tenía una nota de programa explicativa para el espectador?

Sí, había una nota que contaba un poco el sentido de ese trabajo, no tanto como funcionaba. Hablaba sobre la reflexión acerca de la memoria, sobre Borges, sobre lo incontrolable y sobre lo parcial. El propósito de eso era dar un marco de referencia una guía. A mí me interesaba particularmente, el proceso de descubrimiento por parte del espectador; el trabajo en realidad tenía una apuesta, cuando vos te acercabas al cubo, había una posición en particular que disparaba sola la instalación porque en realidad el sensor veía tu cabeza; pero podías pasar por otro lado y no pasaba nada, veías tan solo una instalación minimalista, de dos cubos. Muchas personas pasaban y veían eso como algo detenido en el tiempo y no imaginaban en ningún momento lo que pasaba al activar la instalación. Todavía hay un juego del azar, de lo intrépido, de lo que es perderse en el mundo. Recuerdo que esto lo asociaba a una muestra que en algún momento vi, no sé si fue en la Bienal de Venecia, en donde yo entraba y veía una mesa, me quedé un rato mirando la mesa y no pasaba nada, mucho tiempo 
después me enteré que la mesa estaba como a 38 grados, estaba caliente la mesa; entonces tenía que ver con esto de quien tiene una actitud frente a la vida, quien pone la mano, quien no la pone, quien se anima a... y eso que queda ahí expectante de que alguien intrépido lo haga. De todas maneras, en el caso de mi obra, la gente se acercaba en general, se movía y disparaba la obra de manera que se intuía lo que pasaba y rápidamente se activaba.

¿Jim Campbell plantea que la interactividad en un caso extremo sucede cuando el público por su interactuar logra modificar el código, que piensas tú de esto?

Cuando pienso en interactividad no pienso tanto en el espectador de hecho, el concepto interacción tendríamos que restringirlo, puedo entenderlo eso en términos del arte electrónico, de cómo se estructuran las interacciones. Yo nunca lo vi así, porque en realidad yo había hecho un trabajo anterior en el 2001 que era interacción de agua con texto, siempre vi la interacción como la posibilidad de vincular mundos necesariamente desvinculados y como posibilidad de metáfora en la relación misma, más allá de que participe una persona o no, y eso es interacción no me importa si modifica una fuerza gravitatoria algo o si un código que se cuenta, eso es físico. En el fondo, entonces pienso que la interacción es algo que está incorporado en nuestra vida, es un a priori de nuestra vida, no hace falta que yo lo reafirme con un juego, me da igual, porque en definitiva las cuestiones de hacia dónde va esa interacción, cual es el objetivo, ¿buscar un diálogo? para eso dialogo con la gente. El arte conoce sobradas experiencias que sin nada de codificación trabajan sobre la interacción, inclusive es una interacción humana, me parecía entonces que para mí eso no era sustancial, que las artes electrónicas tienen un aporte esencial sobre eso. Para mí era distinto, era como la posibilidad artificial de establecer conexiones entre espacios que no son conectados totalmente, por ejemplo, una gota que se evapora y eso me produce un texto que se arma, me parece que genera en el vínculo un juego metafórico que no es fácil de encontrar.

Si el hecho artístico en si no está resuelto, por más que yo busque vínculos filosóficos para determinadas cosas y concepciones sobre interactividad no pasaba nada. Entonces, a mi lo que me enseñaba Libros de arena era eso todo el tiempo. Libros de arena yo nunca imaginé que iba a funcionar como funcionó, Lo pensé, lo hice y resultó sorprendente no porque el código hacia tal cosa o no. Resultó sorprendente el vínculo y la experiencia vinculante de las personas, que no estaba incluso moldeado por un código, que podían ser más o menos responsivos. La gente venía por el vínculo fundamental arquetípico con la arena, todos 
recordamos haber jugado con la arena desde niños, jugar y no tener control sobre el juego. La luz, la arena y esos elementos para mí son esos elementos vinculantes mucho más poderosos, lo tomé de la tradición artística. Yo sabía programar, pero no sé si ese tipo de visiones sobre el arte venían atadas a las artes electrónicas. Pero ¿porqué siempre Libros de arena? porque tiene en juego una serie de elementos que remiten a algo más arcaico, más básico, que remiten a el software de las personas lo que es algo mucho más difícil de programar.

¿La obra en su deambular y probarse con diversos públicos llega a un punto de madurez que la hace inmutable y predecible?

Yo lo que creo que se reanima todo el tiempo es la interacción, el vínculo en sí mismo. La interacción son todas esas sustancias puestas de manifiesto, no solo es el código. Esa apuesta, así como el estar en escena pone en relación cada vez y todo el tiempo esos elementos que calan tan adentro que producen ese gancho, y terminan gustando, no hay mucho que pensar para vivirla.

¿La obra se podría haber resuelto de muchas maneras, porque entonces Borges?

Primero porque siempre tuve mucha afinidad con su escritura, porque muchas cosas que pensé siempre me han resonado casi de un diálogo con sus libros, con él. Es notable que, en este caso, primero pensé en la vivencia, la cual no es una experiencia objetual, pensé primero, vamos a tratar de rescatar esto, reflexionando siempre que lo que quería compartir era la experiencia en sí, el modo de vincularse, con el frio del agua, el movimiento, como se vuelve a hundir el agua en la arena. Te cuento la anécdota, la cual es un poco borgiana. En un comienzo no se llamaba Libros de arena. Yo siempre lo pensé como un baúl en el cual la gente navega en Internet, entonces va juntando cosas. ¿Por qué eran los textos de Borges? La obra se empezó a montar al final del 2003 en el Museo de Arte Moderno. Yo le comenté el proyecto a la directora y ella me dijo yo quiero tener eso. Yo tenía solo esa partecita, faltaba un montón para la producción en una Argentina pos crisis del 2001. Yo le escribo a Laurens, un físico que yo conocía del laboratorio donde trabaja antes quien era un buen programador, le conté del proyecto el cual tenía plataforma Mac y funcionaba bajo el software de Rokeby y le propuse pasarlo a plataforma $P C$, a lo cual accedió. Volviendo a la anécdota, recuerdo que un día de ese verano regresando a casa cansado, me pongo a hacer zapping y justo encuentro una escena en que hay un señor que le quiere vender una Biblia a otro, pero sucede 
que el vendedor quiere mostrarle la primera página al posible comprador y sucede que no puede porque cada que lo intenta siempre hay una hoja entre la primera página y la que agarra. Me doy cuenta que es una película sobre Borges y me dije este es el Libro de Arena de Borges. Me quedé medio choqueado, sentí que estaba haciendo eso, que era la misma idea que yo tenía, que era que la gente pudiese tomar información de la Red pero que no tuviese control, que pudiera leer algo, pero al ratito era ya otra cosa. Entonces me di cuenta que yo lo saqué de ahí, me acuerdo que quedé como perturbado, me decía esto no tiene ningún sentido, porque esto es el Libro de arena de Borges. Al otro día compartí con la directora del museo lo sucedido, y ella me dice en verdad es y no es lo mismo, porque aquí hay un soporte distinto, nada que ver, nunca se hizo algo electrónico sobre Borges en ese sentido. El punto era como lo llamamos, si me pego al Libro de arena de Borges era un riesgo el nombre. Era entonces una ilustración del nombre del libro de Borges, finalmente ella me convenció que estaba bien, que había que pegarse, porque era una cuestión formal y de método tan distinta que estuvo bien y fue un gran acierto.

¿Cuánto de ciencia había en la obra?

Hay mucha matemática y mucha programación.

¿Qué tanto de innovación tiene la obra en su contexto de origen en la escena de Buenos Aires del 2003?

Mirá, es difícil, en ese momento en que surge la obra en realidad a nivel tecnológico todo existía, en el mundo se hacía, acá en Argentina no había tanto de eso, menos en los espacios artísticos convencionales, cuando esta obra se estrena nos pasó, mucha validación, tampoco va a para a cualquier festival. El peso tenía que ver también con el marco donde se estaba. A decir verdad, hubo una antecesora de esta obra que fue la que puso en escena casi todos los elementos por separado, que fue una que armamos en el MALBA con la curaduría de Rodrigo Alonso en el 2003, que fue un poco la prueba del funcionamiento de Windows. No era nada común en la escena de aquel entonces ver esto, era una época en la que éramos pocos los que hacíamos esto, nos conocíamos y sabíamos lo que hacía cada uno, no era lo usual, a nivel de innovación quizás en el campo artístico. Al margen mucha gente trabaja estas cosas desde la academia como la Universidad de Buenos Aires sin embargo a nivel artístico era novedoso aquí. Por supuesto tenías que meterte más de lleno que ahora, había que programar, los programas eran más limitados, la capacidad igualmente. Fue novedoso en 
un determinado contexto, el valor que yo le hallo, es que la obra en sí a nivel pedagógico por todo lo que tuvo que desarrollarse acá en la época de la pos-crisis, con lo que Laurent desarrolló para el proceso de imágenes con Windows hecho por él y por mí, sirvió como columna vertebral para lo que era la columna vertebral de lo que era la carrera de artes electrónicas de la Universidad Tres de Febrero. Desde ahí pudimos estructurar varias materias que trabajaban con la imagen digital y electrónica, que estaban más ligadas al video $\mathrm{y}$ de pronto introducimos en la universidad enseñar estas cosas como matemática, programación un poco más dura. Era como traer otra tradición de las artes electrónicas más anclada en la TV anglosajona de la historia tecno-científica, otra historia. Creo que eso si fue un aporte significativo, dado que la carrera de artes electrónicas no trabajaba desde ese lugar. Para mi ese fue un aporte importante, acercó a muchos chicos a aprender sobre el arte electrónico y estas cosas. También creo sirvió para validar este tipo de arte en espacios museísticos como el MAMBA y el MALBA.

¿Cómo reaccionó el público de aquel entonces?

El público ha cambiado mucho. Frente a Libros de arena me han pasado muchas cosas. Yo creo que es por la materialidad, no por el aspecto electrónico. Fue algo muy contundente, pegó muy de lleno sobretodo en el imaginario de la gente, especialmente aquí en Argentina por el tema de Borges. Creo es un trabajo que acierta en varios puntos, además que es una obra en colaboración con Laurens a nivel tecnológico y en los desarrollos del trabajo, pero también un trabajo desarrollado por Laura Buccellato dado que muchas de las decisiones también fueron bajadas por ella, fue un trabajo muy consensuado en algún punto. Fue una obra que encajó muy bien y tuvo una excelente recepción por parte del público y el medio.

¿De qué manera influyó el apoyo de la empresa privada al desarrollo de las artes electrónicas en Argentina?

En Buenos Aires para el año 2000 en la Universidad Tres de Febrero ya estaba la carrera de Artes electrónicas, ya estaba instalada en el medio, con otra línea de pensamiento, pero no importa ya estaba. En Argentina hay un actor que yo considero es importante, en esa época como te decía la tradición del arte electrónico estaba ligada al sistema discursivo del video, yo creo que quien influye mucho en sacarlo es Fabián Mcmister con quien muchos de nosotros fuimos a la UCLA a trabajar y nos permitió conocer otro paradigma de abordaje de 
las cosas. Quienes teníamos más inclinación por las cuestiones tecnológicas y científicas, no era tanto de la tradición cinematográfica o del video, sino que teníamos otro tipo de inquietud, él pudo canalizar la inquietud de varios artistas que pudimos compartir eso y que en ese momento si bien no éramos muchos cada uno empezó a trabajar sobre sus búsquedas, pero ese nuevo paradigma ayudó mucho, facilitó muchas cosas favoreció el pensar más entrometidos con las cuestiones tecnológicas y creo que eso fue premonitorio. Después sí, vino Telefónica y CCEBA que ya trabajan sobre una escena incipiente. Cuando apareció Libros de arena muchos chicos se motivaron a entrar en el campo, igualmente Rodrigo Alonso me compartía la inquietud de muchos jóvenes que querían saber sobre esto, así fue como entonces armamos el proyecto con Telefónica. 


\section{Entrevista Patricio González Vivo}

¿Cuál es el concepto de autor y de autoría en tu obra?

Creo que hoy por hoy el concepto de autoría cambió muchísimo, el Internet y la posibilidad a través de él no solo de compartir contenidos sino también herramientas, sobre todo cuando trabajás con cuestiones digitales. En mi caso mi background es en sicología, mucho de las cosas que yo aprendí y utilicé al principio provenían de otras personas. Herramientas como Proccesing de código abierto y la comunidad Open Frameworks conformada por una comunidad de autores, creadores y artistas a la cual pertenezco por fortuna y la cual está desarrollando sus propias herramientas. La comunidad está conformada por personas de campos muy diversos de ahí la necesidad de colaboración entre todos en los procesos de construcción de las herramientas y los aspectos técnicos. Creo hay una diferencia entre arte interactivo y arte reactivo. En el arte interactivo uno se imagina un espectador y él como incorporarlo, es un asunto relacional en el cual se generan vínculos, es una forma de diseñar una experiencia en la cual estás teniendo muy en cuenta a la otra persona.

¿La obra está acompañada de una nota de programa en la cual se explican cosas al espectador?

En mi obra Efecto Mariposa no había ningún tipo de comentario al margen de la exhibición, solo estaba el rotulo del nombre de la obra. Yo prefiero las obras que implican la intuición del espectador. Para mi es preferible que no haya un manual junto a la obra.

¿Cuál era el objetivo de la obra, que pretendía?

La obra tuvo un antecedente en el cual yo había trabajado Comúnitas en el Espacio de Telefónica, en ese entonces yo estaba muy involucrado en arte terapia con grupos, así que estaba muy interesado en ver cómo la gente reaccionaba con la tecnología, y hasta donde era un agente de alienación; fue la época del boom de las pantallas táctiles y de las superficies táctiles y reactivas. Lo que yo observé es que la gente dejaba de interactuar entre sí. Así que la obra Comúnitas consistía en cómo darle la vuelta a una superficie reactiva o táctil para generar conexiones entre las personas y el encuentro entre ellas, así que aparece la idea del mándala y la utilización del dibujo en conjunto. Yo me sentí bastante contento con los resultados, y sucedió que cuando la utilicé con chicos que son mucho más transparentes, pude observar algo más, la relación que tenemos con la ansiedad a través de la tecnología. Pude 
observar ese vínculo ansioso con la tecnología. A partir de ahí surge la intriga de cómo sería hacer o proponer un vínculo o una obra totalmente digital que pudiera mediar con esa ansiedad. En ese mismo año apareció la cámara kinect y viendo las posibilidades que ofrece me surge la idea de trabajar con arena. Yo había trabajado con arena en arte terapia, sabía de sus propiedades nobles para recibir impactos, entonces hice un par de experimentos y me surge la idea de generar una simulación que sea súper invitante, que invite al espectador a intervenirla, pero que a la vez proponga un tiempo distinto al que estamos acostumbrados. El algoritmo que simula el crecimiento de las bacterias opera en el sustrato de vida, la cual es la capa que simula la vida en la obra, dicho algoritmo me daba la suficiente posibilidad para regular un crecimiento orgánico en el cual yo como autor pudiera ver hasta qué lugar es cómodo para el espectador y a la vez poder expresar yo algo ahí, pudiendo filtrar y proponer un ritmo distinto. Al tiempo que está sucediendo esto yo propongo el proyecto de la obra al CCEBA el cual es aceptado por su coordinador Emiliano Causa. Mientras estaba desarrollando el proyecto, sucede una erupción de un volcán en Chile en el 2011 que tangencialmente me afecta, por esos días yo estaba reflexionando por la relación entre el individuo y el todo. Igualmente estaba trabajando a esta escala de macro y había la oportunidad de poner a participar al espectador en tu propia intervención micro y observar las relaciones entre lo micro y lo macro. Entonces relacioné el evento del volcán y logré que un amigo del sur me enviara ceniza volcánica de la erupción. Dicha ceniza era gris neutro lo que permitía que en la proyección no hubiese ningún tipo de coloración que se filtre de ahí que decidí remplazar la arena por la ceniza. Los eventos anteriores fueron incidiendo en el cierre de la obra y fue así como se perfiló el nombre de la obra.

¿Cuál es la interfaz de la obra, ella cumplió el objetivo que se buscaba?

Yo quedé muy satisfecho con la interfaz, considero que terminó siendo muy transparente para el usuario, muy intuitiva. Hubo algunos aspectos de la obra que me llevaron a obsesionarme con aspectos técnico como el aprender a programar, y desarrollar un montón de posibilidades de interacción. Dentro de la obra por ejemplo hay la posibilidad de mover las nubes que cargan distintos tipos de humedad, sin embargo, el interactor no lo logra visualizar. A la vez generé en la obra muchas posibilidades de interacción que en la practica el usuario no logra identificar. En ese sentido no es muy transparente la obra.

¿La obra en sus distintas versiones tuvo modificaciones? 
En su esencia la obra se mantiene. Las variaciones que se fueron dando se sucedieron en el aspecto tecnológico, en ese sentido hubo mejoras, por ejemplo, la placa gráfica y su capacidad. Tuve la posibilidad de ser invitado a FILE, evento que tiene un equipo de montaje fantástico. Para este evento dado que la obra requiere estar montada varios meses implico todo un desafío. Las mejoras no fueron a nivel de la interfaz. Se mejoró todo el proceso de guion y de aspectos técnicos de manera que la obra adquirió autonomía y fue posible de montarse e instalarse sin mi presencia y participación.

¿Qué papel juegan lo sensores que activan la obra? ¿Cómo es la relación que el público establece con la obra y ellos? ¿Son evidentes?

Puntualmente lo que Efecto Mariposa utiliza es una cámara 3D, y se funda en una idea que proviene de Natural Interfases, lo que me ayudó muchísimo en términos tecnológicos. Es una tecnología bastante invisible y a la vez agrega muchísima magia. De acuerdo a las edades e intereses, los observadores pueden ser o no ser conscientes de los mecanismos que operan en la interacción. Cuando la mostré a mi familia, ellos no estaban interesados por los aspectos tecnológicos, ellos estaban fascinados usando la obra. También cuando tuve la experiencia de trabajar con chicos de capacidades especiales, observé como ellos disfrutaban la obra en un estado puro. Para otros espectadores el placer radicaba en descubrir cómo funciona, cuáles son sus mecanismos de interacción. Yo siempre dejé la cámara expuesta a la vista. El espectador se siente tranquilo cuando descubre que hay un sensor allí.

¿Cuál es el nivel de multimedialidad y participación de los sentidos por parte del espectador?

El papel central se lo lleva la arena. Antes de vos acercarte obviamente la proyección atrae, la proyección tiene un montón de componentes gráficos, a través de capas y sombras. El nivel técnico es complejo, hay mucha riqueza de texturas también, estos componentes tienen que ver con la parte visual. Sin embargo, el sustrato de texturas cuando el espectador va a tocarlo, esa ilusión se rompe, la arena o la ceniza volcánica al ser materiales tan ricos táctilmente y estar humedecidas para hacerlas más maleables adquiere distintas temperaturas lo cual es percibido al interactuar con ella, igualmente hay lugares en los que el público nunca intervino y la temperatura es más fresca. En particular este aspecto del contacto de la gente con la arena me gusta mucho, activa indirectamente los otros sentidos y adquiere otros 
sentidos; la gente en términos urbanos y civilizados prefiere no ensuciar sus manos, tiene fobia a los gérmenes y la obra de alguna manera convoca al observador a este tipo de experiencias.

¿Cuánto tiempo permanece el público en contacto con la obra? ¿Cuánto tarda en ser modificado el relieve por el contacto del público con la arena? ¿Qué has observado tú al respecto como productor de la obra?

La relación y la reacción del público sucede en distintos tiempos, la parte tectónica o sea el lugar donde se planta un agujero se llena de agua inmediatamente, si tú mueves una isla, la isla pierde toda vegetación inmediatamente. A partir de esta experiencia yo aprendí técnicas de videojuegos que te dan resultados inmediatos, la obra no tiene ningún tipo de delay o retardo las respuestas son inmediatas, incluso el agua hace olas en tiempo real, si tú mueves el agua está hace olas y se propagan. Lo que tarda en aparecer es la vegetación una vez tú la destruyes va a tomar un tiempo para que esta se popule nuevamente de vegetación; en este aspecto es donde yo trabajo el tiempo diferido, aquí la obra no te va a satisfacer inmediatamente, se va a producir un silencio incómodo, es decir los procesos de alteración del relieve activan los algoritmos y estos tiene sus propios tiempos hasta llegar de nuevo a un verde que es signo de vegetación plena.

¿Cuál es la incidencia del espacio y la escala del ambiente expositivo respecto a la obra?

Todas las obras que tienen proyecciones siempre involucran un estado de penumbra lo cual genera una atmósfera y un espacio atractivo para la obra. En FILE se me asigno un espacio con éstas características, también yo siempre pido un espacio de silencio para la obra, solicito ciertos indicadores que hagan que la obra no sea un lugar de paso. Por suerte siempre se le asignó a la obra el espacio adecuado de penumbra y silencio, el cual generó una escena en cierto sentido mística que le da el tono a la obra que yo esperaba, además invita a la contemplación, atrae y hace que el interactor participe de la propuesta.

¿El público logra sumergirse completamente en la obra? ¿Se solapa o se distancia la realidad del espectador con la realidad de la obra?

Lo bueno de la obra Efecto Mariposa es que no estoy proponiendo un universo simbólico muy distinto del real. Los signos que estoy proponiendo son agua, lluvia, ríos, y vegetación que se presentan a escala de la obra, escala macro y que funciona mucho más 
rápido que en la realidad. Los elementos simbólicos que se utilizan ya han sido vividos por el espectador, razón por la cual el proceso de inmersión se da y es un proceso ameno. Creo que el éxito de la obra radicó en el hecho de que no necesita mucho para sumergirse en la realidad de la obra y olvidar la propia. A todos nos gusta jugar en general, la obra invita a cierta lúdica y logra involucrar al espectador en el juego de modificar el relieve, lo lleva a un lugar que él conoce.

Desde tu punto de vista y con base en lo que hemos hablado ¿Es el público interactor, usuario, observador o espectador? ¿Tú que piensas?

Creo yo he vivido un aprendizaje inverso. A lo largo de estos dos años haciendo la maestría en diseño y tecnología, muchos de los compañeros vienen del diseño y se refieren a las personas como usuarios, users testing de la obra, lo cual tiene sentido en el contexto americano dado que la relación servidor-cliente es base del sistema capitalista. Sin embargo, cuando escribo en mi blog o escribo un paper utilizo la palabra interactor a pesar que dicha palabra es también fría, y a la vez me parece algo muy técnico. Usuario no funciona, público tampoco, me remite al teatro. Creo estamos en un momento de transición y hay que pensar en nuevas palabras. Finalmente, interactor es la más cercana, es perceptible y creo con los días aparecerá un nuevo termino. Pienso que la obra genera una eclosión de significados. Creo que el espectador es espectador y es contenido de la obra. Vivimos un presente que dejó de ser lineal, ya las cosas no suceden por siempre, o una razón única, o una medicina única, nos han despojado de todo tipo de fórmulas, vivimos en un mundo relativo.

¿Qué tanto de innovación propuso la obra en su momento?

Creo que la obra tuvo mucho del estado del arte de ese momento, de la tecnología disponible en ese momento, formo parte del boom innovador de la kinect, si yo no hago esa obra, otra persona la habría hecho, la kinect pide a gritos que se le dé este tipo de usos. Si fue innovador en el medio el uso de la kinect. A Emiliano Causa le atrajo el proyecto, creyó en él y en el CCEBA se pudo concretar. Yo sentí que el medio fue muy generoso conmigo. También considero que por esos días se producía mucho discurso, los proyectos que se presentaban tenían un fuerte componente conceptual, apoyados en teóricos como Lacan y Foucault, en contrapartida yo quería hacer algo fresco, sin manual, algo sencillo, experiencial, sin un discurso teórico complejo. Como sabes yo vengo de la sicología, y desde esa perspectiva creo sorprendí a la escena del arte electrónico de Buenos Aires, porque la 
obra no venía de un discurso lacaniano complejo o un discurso simbólico complejo, en ese sentido fue algo sencillo, muy experiencial y lúdico. 


\section{Entrevista a Mariela Yeregui}

¿Cómo ves la participación del público con relación al concepto de autor, crees que el público completa la obra?

En el caso de Proxemia el espectador tiene un rol muy importante. Yo imagino al espectador en esa obra con un doble rol. Un rol de contemplador, la obra tiene una dimensión contemplativa fuerte, $\mathrm{y}$ por otro lado el espectador puede tener una experiencia inmersiva, es una obra que propone una experiencia inmersiva, entonces tiene la posibilidad de contemplarla desde la inmersividad, pero por otro lado tiene la posibilidad de interactuar, de definir con los agentes robóticos el espacio, de ser un agente más entre la comunidad de agentes fónicos.

¿La obra cuando es exhibida por primera vez va acompañada de una nota de programa?

La obra no la tiene. A mí me interesa mucho que las obras tengan su propia autonomía, generar obras que promuevan un acercamiento intuitivo, que el espectador pueda entender, así no sepa con exactitud que es lo que pasa, pero si, desde lo sensorial involucrarse.

¿El espectador logra de manera intuitiva conectarse con el concepto que propone la obra? ¿Desde tu experiencia, que has visto al respecto con relación al espectador?

Sí, totalmente. Pasó algo muy interesante, creo que en cada contexto donde lo mostré hay un componente cultural y social del espectador que hace que la forma de relacionamiento sea diferente; pero si, en todos los casos hay un relacionamiento intuitivo. Por ejemplo, en el caso de Argentina la forma de relacionarse era de una manera, en el caso de Brasil veo comportamientos diferentes, no puedo hacer una generalización como para definirlos de una manera determinada, lo cual sería muy determinista. Sin embargo, veo algunas cosas que son diferenciales, en Alemania, por ejemplo, la gente tenía una actitud más de respeto, la gente no se metía tanto, no tocaba tanto. Entonces me preguntaba también si había un componente proxémico, porque la proxemia es algo cultural, habla de proximidades en el espacio social que están condicionadas por aspectos culturales y eso se notaba en cada contexto donde la mostré. Pero si hay una cuestión intuitiva de relacionarse con la obra en todos los casos.

¿Cómo es el comportamiento de los sensores con relación al público y el espacio? 
Cada esfera reacciona con cada esfera, con los espectadores y con el entorno espacial y tiene la capacidad de sensorializar el perímetro espacial y de todo lo que se le interponga en el camino ya sea espectadores u obstáculos físicos. Cada esfera tiene un dispositivo sensorial que hace que cuando se produce algún tipo de roce, con lo que fuera, se cambia el recorrido y en el evento que no encuentre espectadores, las esferas siempre están en movimiento.

¿Cuál es la interfaz de la obra?

Lo que se propone la obra es el contacto, la proximidad en un entorno social, en ese sentido podríamos decir que la interfaz es una interfaz de contacto que es el propio cuerpo de la esfera, además de los dispositivos electrónicos. Sin embargo, prefiero pensar en una interfaz a un nivel más conceptual en donde la superficie de contacto es el cuerpo, finalmente lo que planteo en la obra es el cuerpo como interfaz y como a través del cuerpo nos relacionamos en el espacio.

¿Qué desarrollos ha tenido la obra en cuanto a su evolución a través de las diferentes muestras?

En Córdoba inicialmente se propuso que las esferas generaran sonido los cuales se tipificarían según la altura, el timbre y la intensidad, para después ser retransmitidos vía streamming, finalmente no se realizó. En México se adicionó un programa, el cual permitía que las esferas al desplazarse por el espacio dejaran una estela de luz sobre el piso, esto estaba dado por una proyección de un pixel sobre la superficie que se controla por programación. En la versión del Palé de Glaze aquí en Buenos Aires se incorporó el mapear los recorridos de las esferas y proyectarlos en una pantalla aledaña a nivel lineal para representar los comportamientos.

El programa que regula los comportamientos de las esferas, incluye uno específico para una esfera que contradice las reglas del movimiento. ¿Esto es visible y notable para el público?

Sí, es muy visible, es completamente transparente, y genera mucha tensión porque se puede ver lo que hay adentro, genera mucha curiosidad lo que hace que la gente se acerque a verla, buscando descubrir la magia que hace que las esferas rodaran solas y cuál era la clave del comportamiento. La esfera también proyectaba una línea roja que también la hacía bastante sugestiva, era casi la esfera que revelaba el secreto. 
¿Qué es lo que hace que el público se sumerja en la obra?

En general creo que el público con la tecnología y sobretodo con este tipo de propuestas que son más inmersivas, lo que generan es cierto maravillamiento. El público se pregunta ¿qué es lo que pasa? ¿porqué sucede lo que sucede?. Pero lo que está sucediendo está sellado en cada uno de los agentes robóticos, no se ve el mecanismo, razón por la que la esfera transparente sea atractiva.

¿Cómo son los procesos de tiempo y el espacio en la obra?

La obra transcurre en tiempo real. No hay tiempos diferidos ni un sistema central que controle, cada esfera tiene su propio dispositivo, su propia "inteligencia". Se genera una situación de incertidumbre porque yo como artista no puedo predecir de antemano como se van a disponer en el espacio los agentes robóticos. Las posiciones que toman en el espacio las esferas son muy curiosas, a veces están muy juntas o muy dispersas. Uno de los aspectos que a mí me interesaban era pensar a estos agentes autónomos como casi dibujantes del espacio, iban dibujando el espacio, el cual era un espacio completamente neutro, negro, no había sensación de espacialidad. El espacio lo creaban las esferas a partir del moverse y el relacionarse y establecer vínculos entre sí, es decir, el espacio era un espacio creado y no un espacio dado o pre-establecido.

¿La obra requería un tipo de público particular o era abierta a cualquier tipo de público?

Yo creo que el público entra en contacto con ella sin mayores distanciamientos. El público se metía mucho con la obra, pasaba mucho tiempo con ella. Yo me detuve a ver las reacciones del público, algo que me interesaba mucho, y lo que noté es que la gente pasaba mucho tiempo en contacto con la obra. Algunos espectadores se tiraban en el piso, hacia como secciones de relajación. Los chicos se relacionaban de manera intuitiva, en seguida se daban cuenta que estaba pasando, el asombro y la magia era evidente para ellos. El público en síntesis busca relacionarse intuitivamente con la obra y la obra realmente logra eso.

¿Cuánto hay de ciencia en la obra?

Bueno, el tema de arte, ciencia y tecnología que está tan trillado en el arte electrónico, yo últimamente trato de desmitificarlo un poco. En el caso de la obra que hablamos yo creo que hay mucho de ciencia. Para que una esfera ruede se necesita mucho conocimiento de física, electricidad, mecánica, no es trivial que una esfera ruede sola. Hay todo un aporte que 
viene de la ciencia y que en particular en mi equipo de trabajo viene dado por el ingeniero electrónico Miguel, compañero en el proyecto. Desde mi perspectiva sigo leyendo mucho sobre sistemas autopoiéticos, su relación con los sistemas desde la biología, recordando a los chilenos Maturana y Varela y los aportes desde otros campos como el de la antropología. Creo que tanto las ciencias duras como las blandas, tienen mucho que decir para entrecruzarse con el arte tecnológico. Yo vengo desde el campo de las ciencias humanas, a mí me interesa esa información proveniente de las ciencias duras, sin embargo, en mi trabajo y en esta obra hay algo que viene sobretodo de las ciencias humanas, hay una visión humanista si se quiere en la construcción de estos sistemas fóbicos, en la emulación de estos sistemas sociales. Yo trato últimamente salirme de este cliché que dice que arte y tecnología es física y matemáticas, en mi caso particular hay un vínculo fuerte con las ciencias humanas y las ciencias sociales.

¿Qué elementos innovadores crees tuvo la obra en el contexto de aquel entonces cuando la obra se mostró por primera vez?

La obra se puso en escena en el 2005. Según Laura Buccellato la directora del MAMBA afirmó es la primera obra robótica de Argentina, yo no podría asegurarlo, aunque no me consta que haya habido otras obras robóticas en ese momento. Yo creo que Proxemia fue como tirar una piedra en el estanque, se generó un florecimiento de lo robótico en Argentina, se generó un interés por este asunto. Yo empecé a trabajar con Paula Gaetano que hizo Alexitimia, hubo otra gente que empezó a trabajar como Emiliano Causa y el Grupo Biopus. Fue un puntapié inicial, porque fue una obra de gran visibilidad, en un espacio importante de ese momento como El Espacio de Telefónica consagrado al arte y la tecnología. La obra tuvo gran recepción, buena acogida y muchos comentarios que ratificaban que había llegado e impactado. 


\section{Entrevista Marina Zerbarini}

¿Para el desarrollo de la entrevista vamos a centrarnos en la guía diseñada previamente, uno de los aspectos a tener en cuenta es el papel del público, me podrías tú decir desde tu papel de creadora productora que pensaste al respecto?

Bueno antes de esa obra, yo había trabajado varias obras para Internet, obras de netart, en donde la participación del espectador es fundamental, porque si no, en realidad no se ve la obra. Sí, está bien, podés poner un video, pero yo no tengo cabeza de video, porque el video necesita una edición, no deja de tener una cierta linealidad, en cambio, la participación del espectador a mí lo que me permite es de alguna forma decir las cosas por fragmentos, por retazos, por cosas sueltas, que para mí es un trabajo enorme darles un orden o una coherencia, son así, ideas, quizás ahí en Internet venía trabajando esto de que el espectador podía ir poniéndose en contacto de alguna manera con cada una de esas ideas y él armaba el recorrido, y la secuencia de alguna manera también la creaba él, hacía como que creaba cosas que yo en mi trabajo no definía.

Las obras de net-art manejan el concepto de hipertexto, inclusive hay una obra que se llama Evelyn fragmentos de una respuesta que en realidad son también pequeños fragmentos de respuestas del intentar abordar el tema de lo que es una mujer. Sin el discurso habitual, siempre que estableces una linealidad armas un discurso y mi idea no era armar un discurso, sino mirar ideas que no estaban enganchadas, pero cada uno de estos links tiene una aleatoriedad que lleva diez links diferentes, que son impredecibles, entonces se va haciendo una superposición de pantallas entre dos y tres pantallas, entre esas diez posibilidades que en general tiene nada más que en imagen más de 300 archivos que se van combinando aleatoriamente, es más, ya a esta altura yo no lo puedo navegar como yo quiero. No es exactamente que el espectador tenga la libertad de enlazar como él quiere, porque tampoco puede, pues en realidad es un cálculo matemático, un algoritmo que te va llevando a una serie de posibilidades que es la computadora la que resuelve. ¿La participación del espectador es pasiva como en el caso de observar una pintura? No, En este caso en Evelyn se invita al espectador a que participe enviando imágenes, enviando sonidos, también en algunos diálogos que tiene con una simulación, la incorporación de nuevo material por parte del espectador está modificando la obra original, inclusive te conecta con un web-blog en el que el espectador va poniendo su opinión. En el caso de las obras tradicionales como muchas 
otras permiten que vos incorporés e interpretés, pero eso forma parte del espectador, en cuanto mayor riqueza tenga el espectador, mayores links podrá hacer en una obra tradicional, pero acá tiene la obra en forma intrínseca, el espectador introduce información que modifica la obra y eso es una diferencia importante.

¿Que es lo que el público modifica en la obra de net-art?

El público incorpora un material que antes no estaba y que otro espectador en otro punto de la red puede también modificar, así se generan redes y sentidos que se socializan en tiempo real de manera virtual.

Regresando a la obra Calor, vapor, humedad, Turner siglo XXI, ¿cómo el público frente a las posibilidades de interacción que tú le propones actúa?

Bueno, como acá ya estás con un objeto físico, la participación es también distinta, porque aparte se mezclan posibilidades. Si el espectador participa individualmente, hay sensores de temperatura en cada una de esas manoplas, que están tomando la temperatura de cada persona, y que aleatoriamente va a hacer un juego de luces que responden a una programación que genera sonidos, y que en este caso en vez de generar sonidos generan luces, eso también es aleatorio. Si el espectador es más social y participan cuatro al mismo tiempo, entonces la temperatura de esas manos se puede sumar y con esto logran encender el vaporizador produciendo que se llene de vapor la obra, que es el efecto o el resultado esperado tanto por el público como por el artista. En el caso que no haya interacción por parte de los espectadores, la obra tiene incorporado un temporizador que cada 10 minutos hace funcionar el proceso de emisión de vapor. El tema del vapor hace referencia a los asuntos atmosféricos y climáticos, los cuales tendrán diversas connotaciones dependiendo del lugar en donde se exhiba la obra (el vapor dadas sus propiedades físicas es muy poco controlable) recuerdo que la obra se mostró en la ciudad de Rosario en diciembre durante el verano, y sucedió que una vez instalada la obra, yo me fui a pasear en la mañana y cuando regrese en la tarde para la inauguración, dadas las altas temperaturas del ambiente ocasionadas por el verano, las manoplas de las obras tomaron la temperatura ambiente, situación que ocasionó que la obra emitiera vapor continuamente el cual se condensó, al regresar me estaban esperando porque la obra chorreaba agua por todas partes. Al otro día yo debía regresar a Buenos Aires y dado el asunto del calor y de la humedad en aumento en la ciudad de Rosario tuve que exhibir la obra desactivando el mecanismo de emisión de vapor el cual no respondía a una programación, dado que no era mi interés diseñar un aparato tan controlable como si 
fuera un artefacto de frío o calor. También ocurrió que las plantitas naturales que están al interior de su habitáculo generan su propio ecosistema, produciendo vapor y humedad independiente del vapor de la otra semiesfera que se genera cada diez minutos o por la interacción de los espectadores a través de las manoplas.

¿Cuál es la respuesta en términos de tiempo e interacción de los espectadores frente a la obra cuando tú has tenido la oportunidad de observarlos?

El concepto de tiempo en la interacción es bastante importante, si hay interacción hay participación y hablamos entonces de un tiempo participativo, las personas al interactuar con la obra ponen en juego temporalidades de la obra. Las personas en la interacción se quedan como acariciando las manoplas, atrapados por la atmósfera que observan y el ecosistema de las plantitas, a pesar de la dureza de las manoplas. Después, se observa que los espectadores se reúnen y se juntan varios con el fin de activar el vaporizador, lo cual les trae y les interesa.

¿Qué nivel de inmersión por parte del espectador genera la obra? ¿Logra la obra alterar el plano de realidad del espectador y trasladarlo al plano de realidad de la obra?

Supongo que sí, el espectador hace contacto con las manoplas, se queda observando la naturaleza interior de la obra, observa las variaciones de intensidad de la luz, y del sonido, los cuales responden a la programación pre-establecida según la temperatura ambiente, de manera que si tenés un ojo fino entrenado, podés sumergirte en las variaciones lumínicas. Los prismas instalados reflejan unos textos al revés, proyectados desde una filmina, los cuales capturan la atención del espectador en su intento de descifrarlos lo cual es imposible. Creo que la situación de participación por parte del espectador se da.

¿Crees que el público completa la obra con su participación?

Sin público la obra se queda a mitad de camino. La obra al final del día queda en un determinado estado, ese determinado estado se mantiene, cuando vos encendés la obra no vuelve a ser, mientras la obra está expuesta la obra no vuelve a ser, la obra nunca es la misma, hay un componente de aleatoriedad.

Jim Campbell dice que la intervención del espectador en una situación extrema de participación puede llevar a que incluso la obra se destruya, al respecto qué opinas?

Yo creo que ese es el sentido de la participación del espectador, no estamos ante el mecanismo de una máquina, una maquina se enciende, cumple su función se apaga, pero cuando los artistas trabajamos con esto, la idea es que eso deje de ser una maquina en ese 
sentido, aunque uno no niega que está trabajando con lo maquínico, sino que la obra pueda incorporar elementos que este caso se los incorpora un otro, un ser humano.

¿Había una nota de programa explicativa para el espectador junto a la obra?

En general no tiene, la gente interpreta lo que quiere, sin embargo, si hay indicaciones sobre como apoyar la mano por parte del espectador, el público es un público importante, las indicaciones hablan de que la temperatura de las manos va a ser censada, que se trata de un entorno natural, y que algo de su cuerpo va a ser intervenido.

¿Qué tanto de ciencia hay en la obra, teniendo en cuenta la relación arte, ciencia y tecnología?

Sí, tiene que ver con lo natural, la temperatura y la humedad, ver como reacciona el vapor, el componente biológico que tiene que ver con las plantas, eso es lo que tiene de ciencia. De tecnología todo lo que tiene que ver con las interfaces, dispositivos, sensores, el manejo de las respuestas que dan los sensores. En cuanto a lo científico, tiene que ver con la concientización que permite la obra con respecto a la incidencia de lo humano en el mundo, todos participamos.

¿Qué tanto hay de innovación en esta obra teniendo como referente la circunstancia del 2005?

Me ubico en Buenos Aires 2005, lo que tú puedes comprender es que formamos parte de una red donde se involucra lo tecnológico, lo científico y lo artístico, que conforman un determinado lenguaje. Las obras funcionan metafóricamente como prismas, como edificios con letritas, los cables están a la vista, se pueden observar las conexiones de lo tecnológico. Lo innovativo de la obra en la escena de Buenos Aires en el 2005 creo que fue el componente biológico, hubo una preocupación por el diseño del entorno, el hecho de trabajar con luz, con LEDs nos llevaba a diseñar una vidriera, cosa que no se quería, por lo tanto, se requirió un estudio profundo de los prismas, su escala y su funcionamiento, para que no parecieran envases y lograr salir de la imagen del mercado, y romper de alguna manera esa forma. El tema del vapor y su relación con lo biológico yo creo que fue un elemento innovador.

¿A futuro cómo crees la obra seguirá evolucionando?

A futuro creo, es el concepto del tiempo en lo biológico, me encuentro investigando en mi doctorado acerca de qué es lo que ocurre con el tiempo en este tipo de obras, estableciendo diferencias en cuanto a lo que es un tiempo maquínico y un tiempo biológico. 


\section{Anexo 2. Guía de entrevistas.}

El propósito de la siguiente guía fue orientar el proceso de entrevista a los artistas y el análisis del rol del público en las instalaciones seleccionadas desde los productores. Ésta guía sirvió de marco referencial para el proceso que se llevó a cabo en la investigación.

La guía presentó directrices flexibles y abiertas para los procesos de tipificación del público. La entrevista se dirigió hacia la observación, análisis y escrutinio del público con el fin de recolectar la información proveniente de los artistas al respecto. Se observaron las etapas de diseño, proceso, puesta en escena de la instalación y el rol del público en dichas etapas.

Con el fin de propiciar el acercamiento a las obras desde diversas perspectivas, se puso a consideración de los artistas entrevistados los siguientes cuestionamientos para el análisis, procurando el acercamiento al proceso de creación y desarrollo en las relaciones entre el espectador, el creador y la propuesta.

\section{Como acercarse a una definición:}

¿Qué clase de obra es? ¿Deviene de un proceso de investigación? ¿Es consecuencia de procesos experimentales, conceptuales, artísticos o técnicos; o su interrelación? ¿Cómo define el artista a la obra?

Aproximación al concepto de Autor:

¿Quien es el autor(es) de la obra? ¿O co-autor(es)? ¿El espectador es coautor?

Texto explicativo o de programa de la obra:

¿La producción observada posee un texto explicativo? ¿Qué papel cumple o tiene?

Variaciones Temáticas:

¿Se puede enmarcar la obra en una temática específica? ¿Hay un foco particular que sea relevante?

\section{Aspectos Conceptuales:}

¿Qué conceptos sustentan la obra? ¿Cómo se comunican dichos conceptos? ¿Cómo los acoge el espectador? ¿Es un detonador para la fase de creación-experimentación? ¿El propósito de la producción es comunicar el concepto?

\section{Propósitos de la producción:}

¿La obra tiene un objetivo? El propósito puede ser diverso por ejemplo expresar comunicar una idea. Puede pretender generar una valoración estética por parte del espectador, o invitar al análisis de un tema específico, o genera una interacción física del espectador... Pueden ser todas las anteriores. ¿Cuál es la pretensión de la obra? ¿Qué es lo que pretende lograr?

Espectador/observador:

¿Plantea un tipo de público en particular la obra? ¿Qué actuación se le propone? ¿Cuántos espectadores interactúan en forma simultánea? ¿Cuántos actúan directamente con el sistema? ¿El público se relaciona entre sí? ¿Se propone algún tipo de práctica colaborativa? 


\section{Procesos de Interacción:}

¿Es interactiva la producción? ¿Qué maneras específicas de interacción propone la producción? ¿La interacción genera outputs del sistema? ¿La interacción por parte del espectador modifica los algoritmos y procesos de respuesta? ¿La obra para completarse requiere la interacción del espectador? ¿Los espectadores son conscientes de que su presencia y conducta tiene influencia activa en la obra? ¿La obra permite que la realidad interna de la obra conviva con la realidad externa del espectador?

\section{Estrategia para la interacción:}

¿Cómo se propicia la interacción? ¿Cómo se motiva al usuario a entrar en contacto con el sistema? ¿Hay una maniobra reconocible? ¿La misma, es clara ¿Se produce finalmente la interacción? ¿En tiempos reales? ¿De la forma planeada? ¿Es posible pensar en tácticas alternativas, que tendrían un resultado más relevante? ¿Se observan comportamientos no esperados?

\section{Sobre la interfaz:}

¿Qué interfaz propone la obra? ¿Realiza su función acertadamente? ¿Existe una alternativa más sencilla que resuelva el asunto de la interacción y que no interfiera en otros componentes de la obra? ¿Qué valor representa la interfaz más simple o la más compleja?

Sobre los sensores:

¿El espectador logra percatarse de la existencia de sensores? ¿Es relevante para la obra y la experiencia del espectador la evidencia de los sensores en la obra? ¿Los sensores son explícitos o tácitos? ¿La consciencia por parte del espectador del uso de sensores modifica el comportamiento del mismo?

\section{Sobre el soporte:}

¿Cuáles son los soportes de la obra? ¿qué relaciones hay entre el soporte, el concepto y la intensión de la obra? ¿Los soportes utilizados son de tipo temporal o espacial? ¿Cuál es la materialidad de los soportes?

\section{Sobre la multimedialidad:}

¿Qué diversidad de medios utiliza la obra? ¿Los medios utilizados se complementan o compiten entre sí? ¿Los códigos y lenguajes utilizados como afectan la percepción?

\section{Sobre los sentidos:}

¿Que sentidos se involucran? ¿Se combinan, se complementan? ¿Cómo se relacionan entre si los diferentes sentidos?, ¿Se producen fenómenos de sinestesia?

\section{Acerca de la hipertextualidad:}

¿La obra es hipertextual? ¿La obra es alineal? ¿La obra es multilineal? ¿La hipertextualidad tiene relación directa con la posibilidad de interacción?

\section{El fenómeno de inmersión:}

¿Qué tanto se sumerge el público en el ambiente presentado? ¿Se identifica con claridad la existencia de una realidad virtual o aumentada? ¿Cuál es la táctica para sumergir al público en la obra? ¿En cuánto se parecen las leyes de la realidad virtual a las leyes de la realidad del usuario? ¿Las respuestas del sistema a la interacción, son en tiempo real? ¿La realidad creada por la obra se superpone a la realidad del espectador o permanecen independientes la una de la otra? ¿Qué estimulo en particular permite la inmersión?

\section{Tiempo real}

¿La obra proporciona respuestas en tiempo real?, ¿La obra proporciona respuestas tiempo diferido? ¿El tiempo de respuesta de la obra condiciona los niveles de participación e inmersión del espectador? 


\begin{tabular}{|c|}
\hline $\begin{array}{l}\text { ly } \\
\text { se } \\
\text { un } \\
\text { tos } \\
\text { tes }\end{array}$ \\
\hline Materialidad: \\
\hline $\begin{array}{l}\text { ¿La obra es inmaterialidad o material? ¿Cuál es su soporte tangible o intangible? ¿La } \\
\text { interactividad de la obra depende del soporte? }\end{array}$ \\
\hline (1) \\
\hline $\begin{array}{l}\text { ¿Cuál es el lugar de destino de la producción? ¿Espacio e interfaz conforman la obra? } \\
\text { ¿Qué propiedades del espacio son modificadas por la obra? ¿Cómo influye el espacio en } \\
\text { la obra o esta podría existir en cualquier espacio? ¿Se sostiene la obra fuera de ese espacio? }\end{array}$ \\
\hline Público: \\
\hline $\begin{array}{l}\text { ¿A qué tipo de público se dirige la obra? ¿La obra requiere de un público especifico } \\
\text { destinatario de la obra? ¿Es un público de museo? ¿Qué instrucción, código o lenguaje son } \\
\text { solicitados al público? ¿Qué nivel/es de lectura posee la obra? }\end{array}$ \\
\hline Ciencia: \\
\hline $\begin{array}{l}\text { ¿Cuánto hay de investigación en la obra? ¿Cuál fue la hipótesis previa? ¿Qué metodología } \\
\text { se ha utilizado en la producción del resultado técnico, conceptual o estético? ¿Qué reglas } \\
\text { al interior del sistema se siguieron? ¿Hubo una investigación? ¿La obra produce } \\
\text { información o conocimiento? ¿El público se da cuenta del componente tecnológico o } \\
\text { científico? }\end{array}$ \\
\hline Experiencias/Antecedentes: \\
\hline $\begin{array}{l}\text { ¿Experiencias similares con anterioridad a la producción? ¿En caso de referentes } \\
\text { anteriores, que aportaron en cuanto a la solución de los aspectos técnico y de producción } \\
\text { de la obra? }\end{array}$ \\
\hline Innovación \\
\hline $\begin{array}{l}\text { ué innovación propone la obra respecto a las formas de interacción? ¿Qué innovación } \\
\text { opone la obra respecto a las formas de inmersión? ¿El público se comporta como } \\
\text { pectador - observador - interactor en relación con la obra? }\end{array}$ \\
\hline
\end{tabular}

La presente guía se adaptó a los fines de la investigación que se llevó a cabo teniendo como referentes: (Piñero, 2006), (Burger, 1987), (Wikin, 1984). 